Florida International University

FIU Digital Commons

3-29-2019

\title{
Stable Isotope Analysis of Japan Sea and East China Sea Sediments: Late Pleistocene Paleoceanographic Reconstructions
}

Heather Dawn Black

hblac012@fiu.edu

Follow this and additional works at: https://digitalcommons.fiu.edu/etd

Part of the Biogeochemistry Commons, Oceanography Commons, and the Sedimentology Commons

\section{Recommended Citation}

Black, Heather Dawn, "Stable Isotope Analysis of Japan Sea and East China Sea Sediments: Late Pleistocene Paleoceanographic Reconstructions" (2019). FIU Electronic Theses and Dissertations. 4021. https://digitalcommons.fiu.edu/etd/4021

This work is brought to you for free and open access by the University Graduate School at FIU Digital Commons. It has been accepted for inclusion in FIU Electronic Theses and Dissertations by an authorized administrator of FIU Digital Commons. For more information, please contact dcc@fiu.edu. 


\section{FLORIDA INTERNATIONAL UNIVERSITY}

Miami, Florida

\section{STABLE ISOTOPE ANALYSIS OF JAPAN SEA AND EAST CHINA SEA SEDIMENTS:}

LATE PLEISTOCENE PALEOCEANOGRAPHIC RECONSTRUCTIONS

A dissertation submitted in partial fulfillment of

the requirements for the degree of

DOCTOR OF PHILOSOPHY

in

EARTH SYSTEMS SCIENCE

by

Heather D. Black 
To: Dean Michael R. Heithaus

College of Arts, Sciences and Education

This dissertation, written by Heather D. Black, and entitled Stable Isotope Analysis of Japan Sea and East China Sea Sediments: Late Pleistocene Paleoceanographic Reconstructions, having been approved in respect to style and intellectual content, is referred to you for judgment.

We have read this dissertation and recommend that it be approved.

$\begin{array}{r}\hline \text { Laurel Collins } \\ \hline \text { Leonard Scinto } \\ \hline \text { Rudolf Jaffe } \\ \hline \text { William Anderson, Major Professor }\end{array}$

Date of Defense: March 29, 2019

The dissertation of Heather D. Black is approved.

Dean Michael R. Heithaus

College of Arts, Sciences and Education

Andrés G. Gil

Vice President for Research and Economic Development and Dean of the University Graduate School

Florida International University, 2019 
(C) Copyright 2019 by Heather D. Black

All rights reserved. 


\section{DEDICATION}

This dissertation is dedicated to my parents, Mae and Bobby Inscoe. None of this would have been possible without their constant and continuous support. 


\section{ACKNOWLEDGMENTS}

I would like to begin by thanking my advisor, Bill Anderson, for years of advice and encouragement. Bill has taught me how to work well independently in addition to being a productive member of large, interdisciplinary collaborations with our IODP colleagues. He has provided endless support during instrument malfunctions, experiment failures, and funding issues, all the while teaching me how to research and write more efficiently. Bill has had a profound impact on my journey to become a better scientist and without him this dissertation would not have been possible.

My committee members have also been a system of tremendous support over the last few years. Laurel Collins has been a constant source of advice on how to better navigate the graduate school and early career processes as well as a great source of knowledge of foraminifera and ancient environments. Leonard Scinto always reminded me to take a step back and conduct my research in a hypotheses-driven manner as well as helping me refocus on big-picture concepts instead of the smaller details. Rudolf Jaffe has been an extensive source of organic chemistry knowledge and graciously allowed me to work countless hours in his laboratory.

I would also like to personally thank all of those that provided scientific support: John Harris, Maria Sabando, Peter Regier, and Mark Kershaw; thank you for countless hours of sample preparation and analysis, patiently teaching me new methods, and helping to resolve any research issues that inevitably came about. I would also like to thank all of my IODP colleagues, especially Ryuji Tada, Rick Murray, Stephen Gallagher, Takuya Sagawa, Carlos Alvarez-Zarikian, Christopher Kinsley, Bobbi Brace, Ann Dunlea, and Chloe Anderson. Thank you for years of collaboration, support, and advice. 
Alan Roebuck, Carrie Rebenack, Ariel Freidenreich, Alexa Rodzinski, and Felix Thompson provided years of constructive criticism and emotional support; without them I likely never would have made this far. I am truly thankful that every time I was ready to quit, they always provided the motivation to keep going.

Lewis Midkiff has been my rock over the last decade; I first said I wanted to study climate change when we were in high school and he has been fundamental in my scientific journey since. Without him I never would have found my love of the University of Alabama, football, or geological sciences. Thank you for continuing to love and believe in me.

My parents have been profoundly influential in my life and I am so incredibly thankful for all of the opportunities they have provided. Words cannot describe how appreciative of all of the time, energy, and patience it must have taken to raise me. Thank you, Mom and Dad, for 30 years of unconditional support, encouragement, and love.

The following doctoral research was funded via the US Science Support Program, the Integrated Ocean Drilling Program, the European Consortium for Ocean Research Drilling, and FIU's Dissertation Year Fellowship. All samples were provided by the Integrated Ocean Drilling Program. 


\section{ABSTRACT OF THE DISSERTATION \\ STABLE ISOTOPE ANALYSIS OF JAPAN SEA AND EAST CHINA SEA \\ SEDIMENTS: LATE PLEISTOCENE PALEOCEANOGRAPHIC \\ RECONSTRUCTIONS \\ by}

Heather D. Black

Florida International University, 2019

Miami, Florida

Professor William Anderson, Major Professor

The East Asian Monsoon system is an important dynamic of East Asian climates, affecting over one-third of the world's population. Marginal seas within East Asia are ideal environments to study past fluctuations of monsoon intensities and durations as they are sensitive to climatic and glacio-eustatic sea level changes. This study focuses on continuous sedimentary sequences collected from three Integrated Oceanic Drilling Program Expedition 346 sites; Sites U1426 and U1427 in the Japan Sea and Site U1429 in the East China Sea. Elemental concentration $\left(\% \mathrm{TOC}, \% \mathrm{TN}\right.$, and $\left.\% \mathrm{CaCO}_{3}\right)$ and stable isotope ratios $\left(\delta^{13} \mathrm{C}\right.$ and $\left.\delta^{15} \mathrm{~N}\right)$ are viable proxies to reconstruct past relative productivity rates. Japan Sea sediments show clear differentiation between glacial and interglacial periods in the proxies studied with increased elemental concentrations and isotopic enrichment indicative of increased relative paleoproductivity rates occurring in interglacial periods with sill depths of the Tsushima Strait $>70 \mathrm{~m}$. Glacial periods, in comparison, generally have decreased relative paleoproductivity rates with decreased elemental concentrations and isotopic depletion. Nitrogen isotopes $\left(\delta^{15} \mathrm{~N}\right)$ do not follow the same 
enrichment cycles as the other geochemical proxies and generally show the most enriched values during glacial low stands when sea levels are lowest, likely indicating anoxic bottom water conditions and denitrification through bacterial processes. The Mid-Pleistocene Transition (MPT) was also identified in Site U1426 sediments through the use of continuous wavelet analysis and multitaper method spectral analysis. Before the MPT, the higher frequency orbital periods of precession and obliquity dominated the paleoproductivity cyclicities while a lower frequency 100,000-year cycle developed at the MPT and dominated the cyclicity to the present. East China Sea sediments do not show clear differentiation between glacial and interglacial periods and instead have relatively constant elemental and isotopic values during the last 350,000 years with the exception of negative excursions during short-term stadial events during Marine Isotope Stage (MIS) 5 and MIS 7. The abrupt negative excursions likely resulted from decreased flow of the Kuroshio Current and reduced upwelling of the Kuroshio Intermediate Water throughout the Okinawa Trough during periods of decreased sea levels. Reduced flow of the Kuroshio Current likely led to the deposition of gravity flow layers during these stadial events. 


\section{TABLE OF CONTENTS}

CHAPTER

PAGE

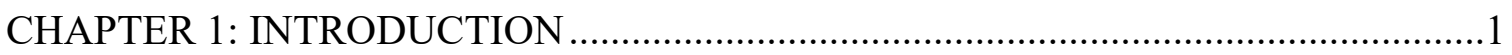

1.1 Productivity and Preservation of Organic Matter ........................................

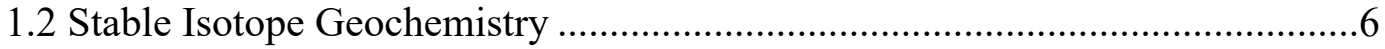

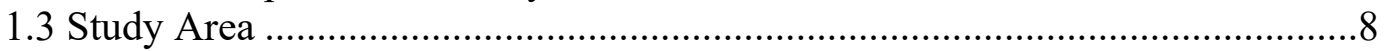

1.3.1 Japan Sea..............................................................................

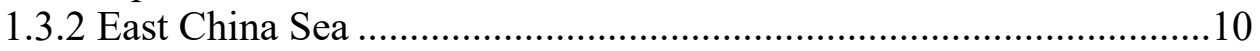

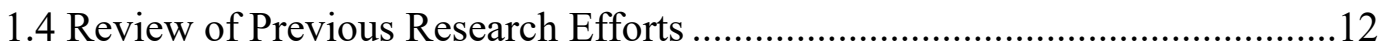

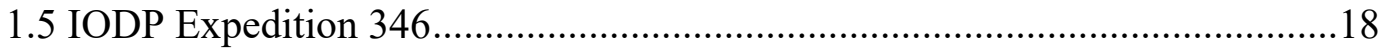

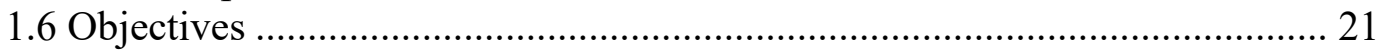

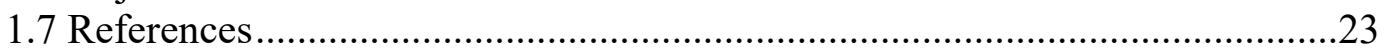

\section{CHAPTER 2: PALEOPRODUCTIVITY HISTORY OF THE JAPAN SEA OVER}

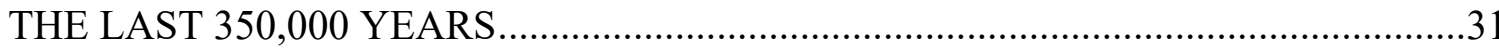

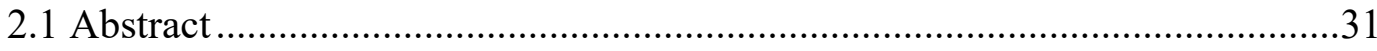

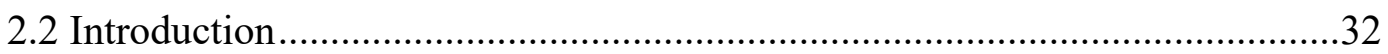

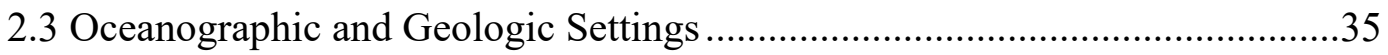

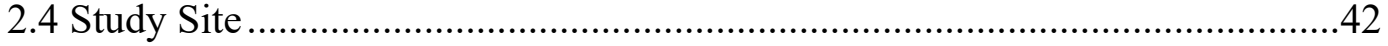

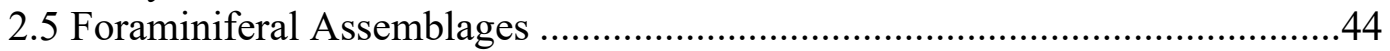

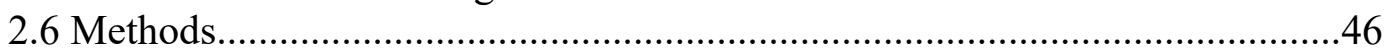

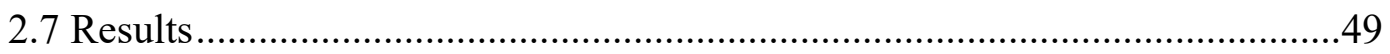

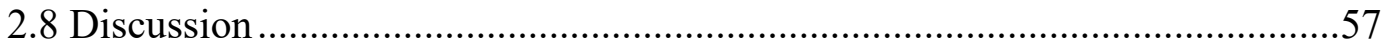

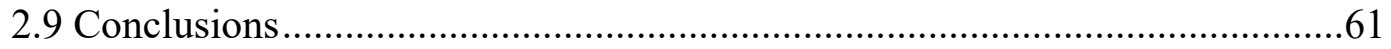

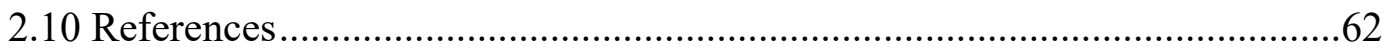

CHAPTER 3: THE MID-PLEISTOCENE TRANSITION AND THE RESULTING

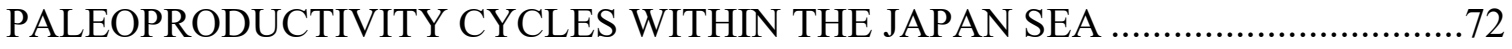

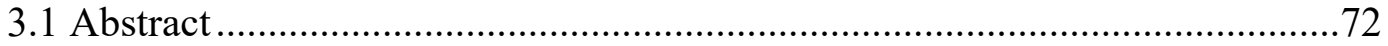

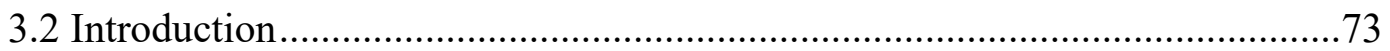

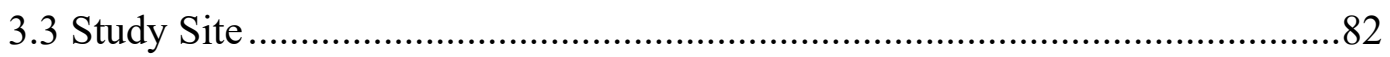

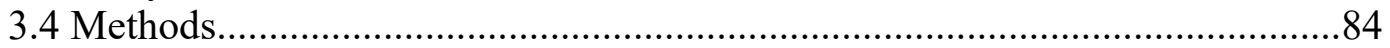

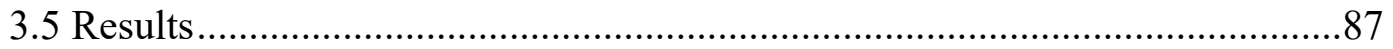

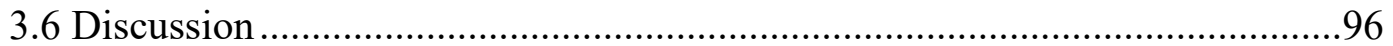

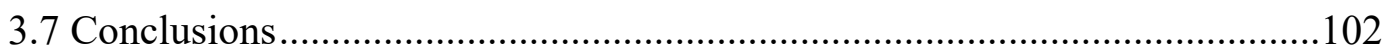

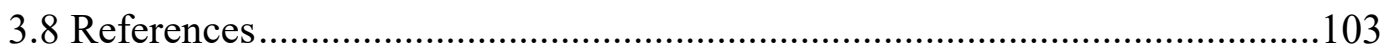

CHAPTER 4: UPWELLING OF THE KUROSHIO CURRENT DURING

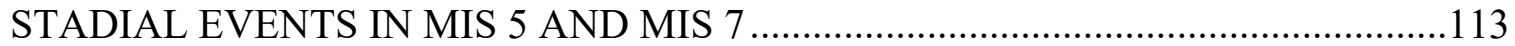

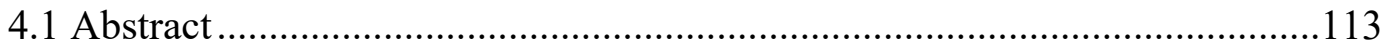

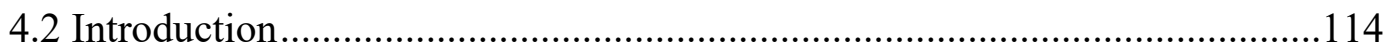

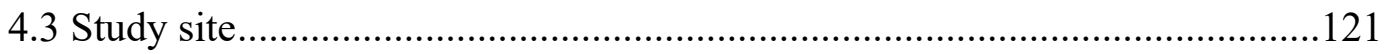

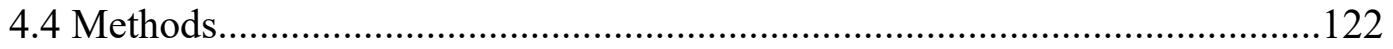




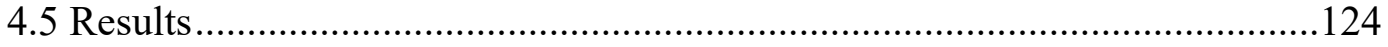

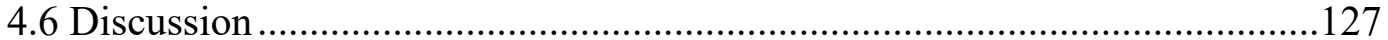

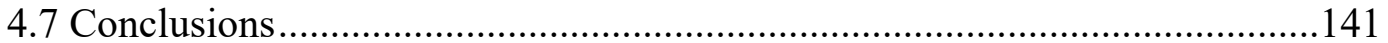

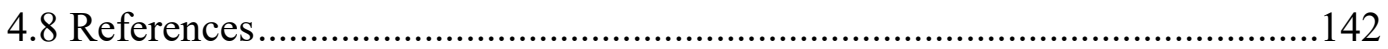

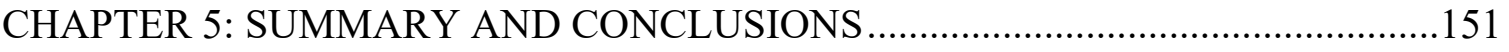

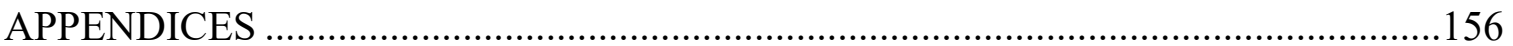

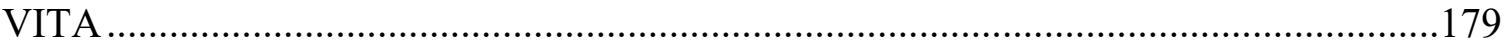




\section{LIST OF TABLES}

TABLE

PAGE

Table 2.1. The contribution of geochemical proxy variables in PCA calculation for MIS 1 through MIS 9 (Figure 2.5a)

Table 2.2. The contribution of geochemical proxy variables in PCA calculation for varying sill depths of the Tsushima Strait according to the four circulation modes of the Japan Sea determined by Tada (1999)(Figure 2.5b).

Table 3.1. T-test scores for $\% \mathrm{CaCO}_{3}, \% \mathrm{TOC}, \% \mathrm{TN}, \delta^{13} \mathrm{C}$, and $\delta^{15} \mathrm{~N}$ between glacial $(\mathrm{n}=65)$ and interglacial periods $(\mathrm{n}=71)$. In T-test analysis, $\mathrm{t}=\mathrm{t}$-value where larger values indicate significant differences between the sample mean and null hypothesis; $\mathrm{df}=$ degrees of freedom or the number of independent sample values; $\mathrm{p}=$ probability value to determine statistical significance

Table 3.2. The mean and variance of $\% \mathrm{CaCO}_{3}, \% \mathrm{TOC}, \% \mathrm{TN}, \delta^{13} \mathrm{C}$, and $\delta^{15} \mathrm{~N}$ between glacial $(n=65)$ and interglacial periods $(n=71)$ calculated in JMP software

Table 3.3. Multitaper method (MTM) spectral analyses for the period after the MPT (0-773 ka) indicate cyclicity peaks in thousands of years (ky) for $\delta^{18} \mathrm{O}, \% \mathrm{CaCO}_{3}$, $\% \mathrm{TOC}, \delta^{13} \mathrm{C}, \% \mathrm{TN}$, and $\delta^{15} \mathrm{~N}$

Table 3.4. Multitaper method (MTM) spectral analyses for the period before the MPT (774-1314 ka) indicate cyclicity peaks in thousands of years (ky) for $\delta^{18} \mathrm{O},{ }_{0} \mathrm{CaCO}_{3}, \% \mathrm{TOC}, \delta^{13} \mathrm{C}, \% \mathrm{TN}$, and $\delta^{15} \mathrm{~N}$

Table 3.5. Heterodynes and their related primary orbital periods. Bold heterodynes represent the frequencies identified after the MPT (0-773 ka) at Site U1426. (Modified from Thomas et al., 2016.).

Table 3.6. Heterodynes and their related primary orbital periods. Bold heterodynes represent the frequencies identified before the MPT (774-1314 ka) at Site U1426. (Modified from Thomas et al., 2016.)

Table 4.1 T-test scores for $\% \mathrm{CaCO}_{3}, \% \mathrm{TOC}, \% \mathrm{TN}, \delta^{13} \mathrm{C}$, and $\delta^{15} \mathrm{~N}$ between glacial $(\mathrm{n}=119)$ and interglacial $(\mathrm{n}=135)$ periods. In $\mathrm{T}$-test analysis, $\mathrm{t}=\mathrm{t}$-value where larger values indicate significant differences between the sample mean and null hypothesis; $\mathrm{df}=$ degrees of freedom or the number of independent sample values; $\mathrm{p}=$ probability value to determine statistical significance 


\section{FIGURE}

\section{LIST OF FIGURES}

PAGE

Figure 1.1. The marine carbon cycle with atmospheric and oceanic fluxes in gigatons

C year ${ }^{-1}$. (Modified from Trumper et al., 2009.)

Figure 1.2. The marine nitrogen cycle between the atmosphere, sea surface, and deep ocean environments and the bacterial processes associated with $\mathrm{N}$ conversion. (Modified from Trumper et al., 2009.)

Figure 1.3. Bathymetric map of IODP Exp 346 (red circles) and previous DSDP/ODP (white circles) sampling site locations in the Japan Sea and East China Sea. Surface current systems are also shown (Modified from Tada et al., 2013).

Figure 1.4. Lithographic units (IA, IB, and II) of Site U1426 sediments with core images, lithographic unit descriptions, magnetic susceptibility (SI), gamma ray attenuation (GRA) bulk density $\left(\mathrm{g} / \mathrm{cm}^{3}\right)$, and lightness $\left(\mathrm{L}^{*}\right)$ values. (Tada et al., 2015.)

Figure 2.1. Map of the Japan Sea, modern current flux, and Site U1427. TS = Tsushima Strait; TGS = Tsugaru Strait; SS = Soya Strait; MS = Mamiya Strait; TWC-1, TWC-2, TWC-3 are the first, second, and third branch of the Tsushima Warm Current, respectively. Map was created using ArcMap 10.3 (Modified from Gallagher et al., 2018).

Figure 2.2. Concept diagram of circulation and oxygenation modes within the Japan Sea as a result of increasing sea level and varying ocean current influx. (Modified from Tada et al., 1999.)

Figure 2.3. Age-depth curve (m/ky)(Sagawa et al., 2018) and the mass accumulation rate (MAR; $\mathrm{g} / \mathrm{cm}^{2} / \mathrm{ky}$ ) of Site U1427.The age model was created by stratigraphic correlation of tephra layers and benthic foraminifera $\delta^{18} \mathrm{O}$ isotope values at Site U1427. MAR was calculated by multiplying the linear sedimentation rate (LSR; $\mathrm{cm} / \mathrm{ky})$ by the measured dry bulk density $\left(\mathrm{g} / \mathrm{cm}^{3}\right)$ of the sediment.

Figure 2.4. Global sea level $(\mathrm{m})$ (Spratt and Lisecki, 2016), $\delta^{18} \mathrm{O}(\%)$ (Sagawa et al., 2018), L* (Irino et al., 2018), b* (Irino et al., 2018), calcium carbonate $\left(\% \mathrm{CaCO}_{3}\right)$, total organic carbon $(\% \mathrm{TOC}), \delta^{13} \mathrm{C}$, total nitrogen $(\% \mathrm{~N})$, and $\delta^{15} \mathrm{~N}$ content of sediment samples from Site U1427. Sill depth through the Tsushima Strait was divided into four modes following Tada et al. (1999) 
Figure 2.5 Principal Component Analysis (PCA) of $\% \mathrm{CaCO}_{3}, \% \mathrm{TOC}, \% \mathrm{~N}, \delta^{13} \mathrm{C}$, and $\delta^{15} \mathrm{~N}$ analyzed by (a) MIS 1 through MIS 9 and (b) varying sill depths of the Tsushima Strait according to the four circulation modes of the Japan Sea determined by Tada (1999)

Figure 2.6. Global sea level (m)(Spratt and Lisecki, 2016), $\delta^{18} \mathrm{O}(\%)$ (Sagawa et al., 2018), $\% \mathrm{CaCO}_{3}$, and abundances of $G$. bulloides, Uvigerina spp., G. quinqueloba, $N$. pachyderma and TWC planktics (Gallagher et al., 2018). Sill depth through the Tsushima Strait was divided into four modes following Tada et al. (1999)......

Figure 3.1. Map of the Japan Sea, the modern current system, and Site U1426. TS = Tsushima Strait; TGS = Tsugaru Strait; SS = Soya Strait; MS = Mamiya Strait; TWC-1, TWC-2, TWC-3 are the first, second, and third branch of the Tsushima Warm Current, respectively. The map was created using ArcMap 10.3 (Modified from Gallagher et al., 2018.)

Figure 3.2. Concept diagram of circulation and oxygenation modes within the Japan Sea as a result of increasing sea level and varying ocean current influx. (Modified from Tada et al., 1999.

Figure 3.3. Measured $\% \mathrm{CaCO}_{3}, \% \mathrm{TOC}, \delta^{13} \mathrm{C}, \% \mathrm{TN}, \delta^{15} \mathrm{~N}$, and $\mathrm{L}^{*}$ values for Site U1426. $\delta^{18} \mathrm{O}$ values are from the LR04 benthic stack (Lisiecki and Raymo, 2005). Marine Isotope Stage (MIS) is indicated along secondary y-axis where glacial MIS periods are shaded in gray

Figure 3.4. Continuous wavelet analysis of $\delta^{18} \mathrm{O}$ (LR04; Lisiecki \& Raymo, 2005) and $\% \mathrm{CaCO}_{3}, \% \mathrm{TOC}, \delta^{13} \mathrm{C}, \% \mathrm{TN}$, and $\delta^{15} \mathrm{~N}$ values for Site U1426. The solid black line indicates the $95 \%$ cone of influence. The solid white vertical line indicates the MPT at the Matuyama-Brunhes boundary, $\sim 774 \mathrm{ka}$

Figure 3.5. Multitaper method (MTM) spectral analysis of a) $\delta^{18} \mathrm{O}$ (LR04; Lisiecki \& Raymo, 2005), b) \% $\mathrm{CaCO}_{3}$, c) \%TOC, and d) $\delta^{13} \mathrm{C}$ values after the MPT (0-773 ka; left column) and before the MPT (774-1314 ka; right column). Red lines indicate AR(1) confidence intervals of $99 \%, 95 \%$, and $90 \%$ against robust red noise. Shaded gray areas indicate orbital frequencies of $\sim 100 \mathrm{ky}, 41 \mathrm{ky}$, and $21 \mathrm{ky}$. Individual spectral peaks are indicated numerically in ky units

Figure 3.6. Multitaper method (MTM) spectral analysis of a) $\% \mathrm{TN}$ and b) $\delta^{15} \mathrm{~N}$ values after the MPT (0-773 ka; left column) and after the MPT (774-1314 ka; right column). Red lines indicate AR(1) confidence intervals of $99 \%, 95 \%$, and $90 \%$ against robust red noise. Shaded gray areas indicate orbital frequencies of $\sim 100 \mathrm{ky}, 41 \mathrm{ky}$, and $21 \mathrm{ky}$. Individual spectral peaks are indicated numerically in ky units. 
Figure 4.1. Map of the East China Sea and surrounding land and water bodies. TWC= Tsushima Warm Current; YSWC=Yellow Sea Warm Current; TS=Tsushima Strait; TKS= Tokara Strait; TWS=Taiwan Strait; ETWS=East Taiwan Strait. (Modified from Kawahata et al., 2006.)

Figure 4.2. The relative location of the Kuroshio Current at present, the extent of the East China Sea shelf during glacial periods, and the potential deflected path during glacial periods. (Modified from Gallagher et al., 2015)

Figure 4.3. Benthic foraminifera $\delta^{18} \mathrm{O}$ (Sagawa et al., 2018), linear sedimentation rate (LSR; Sagawa et al., 2018), $\% \mathrm{CaCO}_{3}, \% \mathrm{TOC}, \delta^{13} \mathrm{C}, \% \mathrm{TN}$, and $\delta^{15} \mathrm{~N}$ values for Site U1429. Vertical blue lines indicate tephra layers (Sagawa et al., 2018), red lines indicate glacial terminations TI, TII, TIII, and TIV, and shaded gray areas are glacial marine isotope stages. Dashed blue lines indicate stadial events within the interglacial periods

Figure 4.4. Principle component analysis (PCA) results for Site U1429 comparing the geochemical proxies during different marine isotope stages (MIS 1 to MIS 10)

Figure 4.5. A conceptual model of increased EASM precipitation and the resulting Yangtze River discharge onto the East China Sea shelf. Lower salinity surface water from increased fluvial discharge is transported further offshore, inducing upwelling of the Kuroshio Intermediate Water (KIW) in the Okinawa Trough, which increases primary productivity levels within the East China Sea. (Modified from Chang et al., 2009.)

Figure 4.6. $\mathrm{Ca} / \mathrm{Fe}$ (green line), benthic $\delta^{18} \mathrm{O}$ (black line; Sagawa et al., 2018), and relative sea level (RSL; red line) data for Site U1429 (Modified from Beny et al., 2018)

Figure 4.7. Shipboard core section images of Site U1429 sediment show interbedded sand layers indicative of potential gravity flow layers. a) Sample U1429A-13H-4W$107-108 \mathrm{~cm}$ from MIS 5.2 and b) sample U1429A-15H-1W-57-58cm from MIS 7.4 


\section{ABBREVIATIONS AND ACRONYMS}

\begin{tabular}{|c|c|}
\hline$\%$ & Per mil \\
\hline$\delta^{13} \mathrm{C}$ & Carbon stable isotopic ratio \\
\hline$\delta^{15} \mathrm{~N}$ & Nitrogen stable isotopic ratio \\
\hline$\delta^{18} \mathrm{O}$ & Oxygen stable isotopic ratio \\
\hline $\mathrm{b}^{*}$ & Blue color value \\
\hline $\mathrm{C}$ & Carbon \\
\hline $\mathrm{CaCO}_{3}$ & Calcium Carbonate \\
\hline CCD & Carbonate compensation depth \\
\hline $\mathrm{CCW}$ & Chinese Coastal Water \\
\hline CLP & Chinese Loess Plateau \\
\hline $\mathrm{cm}$ & Centimeter \\
\hline DI & Deionized water \\
\hline DSDP & Deep Sea Drilling Program \\
\hline EA & Elemental Analyzer \\
\hline EAM & East Asian Monsoon \\
\hline EASM & East Asian Summer Monsoon \\
\hline EAWM & East Asian Winter Monsoon \\
\hline ECS & East China Sea \\
\hline ECSCW & East China Sea Coastal Water \\
\hline Exp & Expedition \\
\hline $\mathrm{HCl}$ & Hydrochloric acid \\
\hline
\end{tabular}




\begin{tabular}{|c|c|}
\hline $\mathrm{HClO}_{4}$ & Perchloric acid \\
\hline $\mathrm{IC}$ & Inorganic carbon \\
\hline IODP & Integrated Oceanic Drilling Program \\
\hline IRD & Ice Rafted Debris \\
\hline IRMS & Isotope Ratio Mass Spectrometer \\
\hline JSPW & Japan Sea Proper Water \\
\hline $\mathrm{ka}$ & Thousand years ago \\
\hline ky & Thousand years \\
\hline $\mathrm{L}^{*}$ & Lightness value \\
\hline LGM & Last Glacial Maximum \\
\hline $\mathrm{m}$ & Meters \\
\hline Ma & Million years ago \\
\hline MPT & Mid-Pleistocene Transition \\
\hline MTM & Multitaper Method \\
\hline Mya & Million years \\
\hline MIS & Marine Isotope Stage \\
\hline mbsl & Meters below sea level \\
\hline $\mathrm{N}$ & Nitrogen \\
\hline $\mathrm{NH}_{4}^{+}$ & Ammonium \\
\hline ODP & Oceanic Drilling Program \\
\hline $\mathrm{P}$ & Phosphorous \\
\hline PCA & Principle Component Analysis \\
\hline $\mathrm{Sv}$ & Sverdrup \\
\hline
\end{tabular}


$\mathrm{TN}$

TOC

TWC
Total nitrogen

Total organic carbon

Tsushima Warm Current 


\section{CHAPTER 1: INTRODUCTION ${ }^{1}$}

\subsection{Production and Preservation of Organic Matter ${ }^{1}$}

Although it makes up only a small portion of total marine sediments, organic matter serves an important role in paleoceanographic and paleoenvironmental reconstructions. Preserved organic matter serves as an indicator of past environments, such as surface productivity, sea surface temperature, and source dynamics through the analysis of its geochemistry, such as elemental, stable isotope, and biomarker analyses. The major source of organic matter in marine sediments is from single-celled phytoplankton in the surface waters (Falkowski et al., 1998; Stein, 1991). In order for photosynthesis to take place, photosensitive pigments in phytoplankton must absorb sunlight (Sato \& Moriyama, 2018). Since light penetration decreases with depth, most photosynthesis occurs in the photic zone ( $<100 \mathrm{~m}$ deep). Therefore, most of the contribution of phytoplankton biomass in organic matter is a result of production within the upper portion of the water column that has eventually settled along the seafloor (Meyers, 1997).

Nutrient availability is another limitation in organic matter production. While carbon $(\mathrm{C})$ is a major constituent of aquatic systems, nitrogen $(\mathrm{N})$ and phosphorus $(\mathrm{P})$ are found in bio-limited concentrations (Brasier, 1995). The 106:16:1 ratio of C:N:P, also known as the Redfield Ratio, controls the amount of productivity that can occur, and

\footnotetext{
${ }^{1}$ Modified from Black, H.D., Anderson, W.T., and Alvarez-Zarikian, C. (2018). Data report: Organic Matter, carbonate, and stable isotope stratigraphy from IODP Expedition 346 Sites U1426, U1427, and U1429. Proceedings of the Integrated Oceanic Drilling Program (346).
} 
fluctuates according to environmental conditions as determined by nutrient limitations of one or more of these nutrients (Geider \& La Roche, 2002). Nutrient runoff from terrestrial systems and nutrient cycling within the water column cause the amounts of available nutrients, especially nitrate and phosphate, to vary (Covino, 2017).

Marine nutrient cycles transfer nutrients such as carbon and nitrogen between various oceanic reservoirs, the atmosphere, and underlying sediments. The carbon cycle includes both organic and inorganic carbon and the transformation between inorganic and organic carbon. There are four main components of the marine carbon cycle: 1) the transfer of atmospheric $\mathrm{CO}_{2}$ between the atmosphere and surface oceans, 2) production of marine biomass via photosynthesis, 3) degradation of marine biomass after death, and 4) burial and preservation in deep sea sediments. Fluvial nutrient input can be significant in locations near river deltas but have little impact in open-ocean environments (Jickells, 1998). 


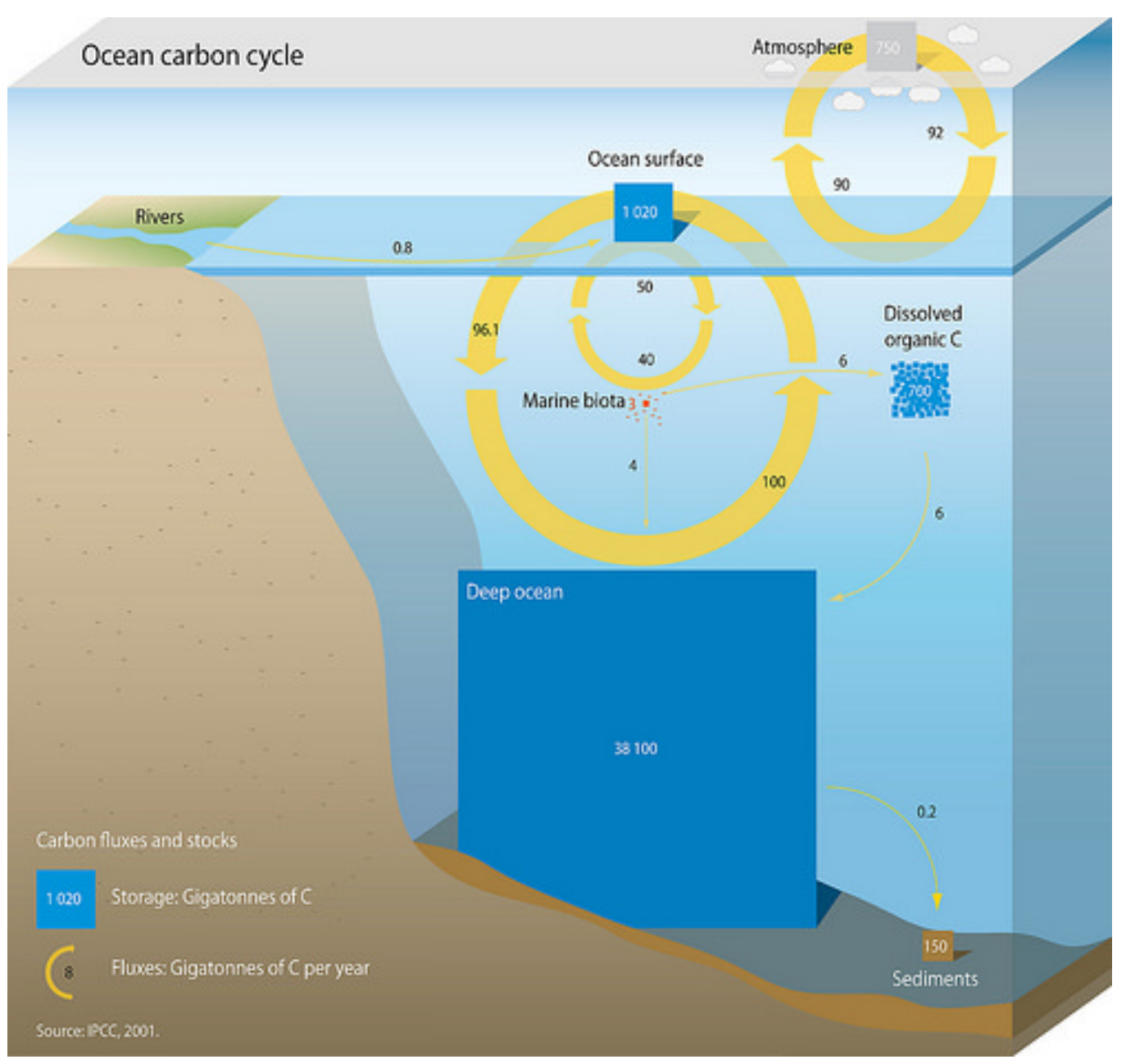

Figure 1.1. The marine carbon cycle with atmospheric and oceanic fluxes in gigatons $\mathrm{C}$ year $^{-1}$. (Modified from Trumper et al., 2009.)

The marine nitrogen cycle is more complex than the carbon cycle because of the significant involvement of bacteria. Nitrogen inputs are typically through dissolved forms in precipitation and $\mathrm{N}_{2}$ transfer between the atmosphere and surface oceans. Since atmospheric $\mathrm{N}_{2}$ is metabolically unavailable to phytoplankton, cyanobacteria convert $\mathrm{N}_{2}$ into nitrate $\left(\mathrm{NO}_{3}{ }^{-}\right)$through nitrogen fixation. The bio-available $\mathrm{NO}_{3}{ }^{-}$is incorporated by phytoplankton, increasing marine biomass in the phototrophic zone. Dead phytoplankton are consumed by other organisms or degraded into ammonium $\left(\mathrm{NH}_{3}{ }^{+}\right)$while sinking 
through the water column. Nitrifying bacteria then convert $\mathrm{NH}_{3}{ }^{+}$into $\mathrm{NO}_{3}{ }^{-}$that can be upwelled through vertical mixing and produce additional biomass. Denitrifying bacteria can convert $\mathrm{NO}_{3}{ }^{-}$to $\mathrm{N}_{2}$ in anoxic deep-water environments and eventually the $\mathrm{N}_{2}$ is cycled throughout the water column, ultimately being returned to the atmosphere.

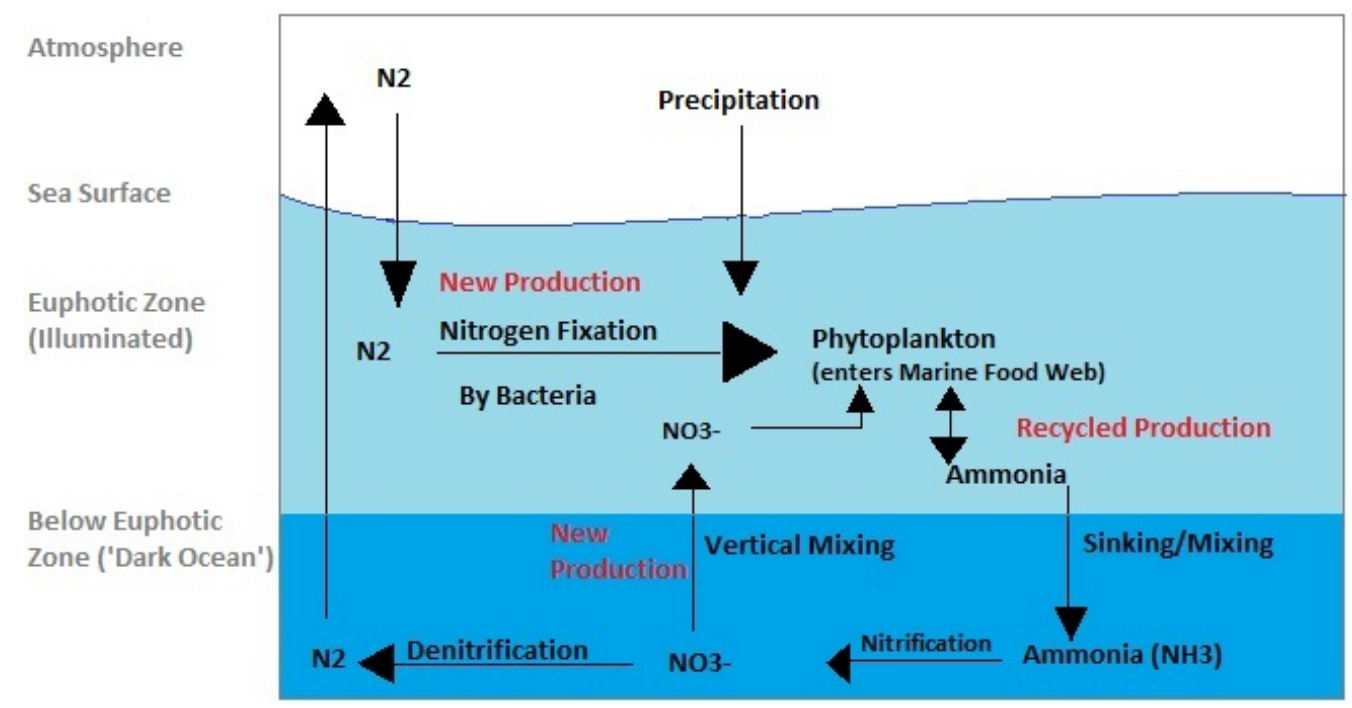

Figure 1.2. The marine nitrogen cycle between the atmosphere, sea surface, and deep ocean environments and the bacterial processes associated with $\mathrm{N}$ conversion. (Modified from Trumper et al., 2009.)

Nutrient cycling transfers nutrients from decomposing organic matter along the seafloor and returns it to the surface waters, mostly through vertical mixing and/or oceanic transport (Ballantyne et al., 2008). Without nutrient cycling the photic zone would eventually become nutrient limited, resulting in decreased algal productivity in the surface waters. The combination of nutrient delivery and mixing within the water column are major controls of the amount of primary productivity in surface waters (Moore et al., 2013). Density stratification within the water column can limit vertical mixing in openocean environments, which can result in a low productivity environment (Dave \& Lozier, 
2010). Seasonal mixing or upwelling conditions can also cause variations in productivity, especially in coastal areas (Berger \& Wefer, 2002).

Organic matter begins to degrade as a result of microbial activity in the photic zone and continues to decompose as it sinks and is eventually deposited on the surface layer of the sediments (Arndt et al., 2013). Typically only $\sim 1 \%$ of the original organic matter from the photic zone is preserved in the organic matter of sedimentary records (Berner, 1989). The amount of productivity in the photic zone and the water depth determine the organic flux, or the amount of organic matter that sinks to a given area per unit of time (Crusius, 1999). In oxic conditions, the water depth influences the amount of degradation that occurs as the organic matter is oxidized by microbes as it sinks to the surface sediments, so deeper water columns allow for increased degradation during transport than shallow water columns (Hulthe et al., 1998). In anoxic conditions, however, organic matter preservation is significantly increased since microbial oxidation is limited (Canuel \& Martens, 1996; Teece et al., 1998).

Organic matter is typically degraded in the water column before it is buried in surface sediments, with more labile fractions being degraded before the refractory fractions (Harvey et al. 1995). Once organic matter has been deposited in the surface sediments, it serves as a food source for benthic organisms and undergoes further degradation by microbial activity (Pomeroy, 1974; Harvey et al., 1995; Teece et al., 1998). High sedimentation rates, however, are likely to decrease the residence time at the sediment surface before being buried by overlying sediments, thereby relatively limiting microbial degradation (Harvey et al., 1995). 
Degradation of organic matter, in both the water column and sediment surface, can cause substantial alteration of organic matter from its original composition (Canuel \& Martens, 1996). Although the total amount of organic matter deposited in the sedimentary record is only a small portion of the original organic matter produced, it typically still contains accurate geochemical records (Hedges \& Keil, 1995). As long as the original geochemical signals are preserved in marine sediments, they can be used as a proxy to determine past paleoceanographic and paleoenvironmental conditions (Meyers, 1994).

\subsection{Stable Isotope Geochemistry}

Carbon stable isotope ratios can be used to determine differences between terrestrial and marine sources depending on the metabolic pathway of the photosynthetic organism (Hedges \& Keil, 1995; Meyers, 1997; Yu et al., 2018). For example, $C_{3}$ plants incorporate carbon in a metabolic way that results in an isotopic fractionation of $\sim-20 \%$ from the atmospheric $\mathrm{CO}_{2}$ source, while some marine primary producers that use dissolved bicarbonate have a fractionation of $\sim 7 \% 0$ (O'Leary, 1981). Therefore, as a mix of $\mathrm{C}_{3}$ and $\mathrm{C}_{4}$ plants, land plant $\delta^{13} \mathrm{C}$ values average $\sim-27 \%$ while marine plant $\delta^{13} \mathrm{C}$ values average $\sim-20 \%$ o (O’Leary, 1981). The $\sim 7 \%$ difference between terrestrial and marine plant material aids the use of $\delta^{13} \mathrm{C}$ values in organic matter to reconstruct source areas over geologic time (Lehmann et al., 2002; Meyers, 1997). In marine environments, however, it is typical to see a combination of terrestrial and marine sources with an isotopic value between -27\%o and -20\% (Meyers, 1994). Carbon isotope ratios can also be used to determine paleoproductivity levels (Meyers, 1997; Müller \& Suess, 1979). Organisms preferentially incorporate ${ }^{12} \mathrm{C}$ over ${ }^{13} \mathrm{C}$ in their metabolic pathways, so in 
periods of increased productivity in the photic zone leads to increased competition, resulting in enriched (less negative) $\delta^{13} \mathrm{C}$ values in the sedimentary organic matter (Fry \& Sherr, 1984).

Like carbon stable isotope ratios, nitrogen stable isotope ratios can also be used to differentiate between terrestrial and marine organic matter sources (Meyers, 1997). Atmospheric $\mathrm{N}_{2}$ has a $\delta^{15} \mathrm{~N}$ value of $\sim 0 \%$, while dissolved nitrate has a $\delta^{15} \mathrm{~N}$ value of 7$10 \%$ (Schubert \& Calvert, 2001). This difference results in $C_{3}$ leguminous land plants, which consume atmospheric $\mathrm{N}_{2}$, to have an average $\delta^{15} \mathrm{~N}$ value of $0.4 \%$ and phytoplankton, which consume dissolved nitrate, to have an average value of $8.6 \%$ (Peterson \& Howarth, 1987). Also like carbon, a mixture of $\mathrm{C}_{3}$ terrestrial and phytoplankton source signals are expected in marine environments (Schubert \& Calvert, 2001) and enriched values can indicate increased primary productivity levels (Meyers, 1997).

The $\delta^{15} \mathrm{~N}$ values must be interpreted with caution when identifying organic matter sources or paleoproductivity levels, however, since the complexity of the nitrogen cycle can affect the $\delta^{15} \mathrm{~N}$ values preserved within the sediment, such as the process of denitrification of nitrate to $\mathrm{N}_{2}$ in anoxic water columns (Mariotti et al., 1982; Montoya et al., 1991). In the case of denitrification, ${ }^{14} \mathrm{~N}$ is preferentially released, which results in the remaining nitrate being enriched in ${ }^{15} \mathrm{~N}$ and higher $\delta^{15} \mathrm{~N}$ values (Altabet et al., 1999; Cline \& Kaplan, 1975). While enriched $\delta^{15} \mathrm{~N}$ values may initially indicate increased levels of productivity within the surface waters, it may instead be indicative of bacterial 
denitrification occurring within the water column or sediment interface (Altabet et al., 2002).

\subsection{Study Area}

\subsubsection{Japan Sea}

The Japan Sea is a semi-enclosed marginal sea with an area of $\sim 1,000,000 \mathrm{~km}^{2}$, an average depth of $\sim 1,670 \mathrm{~m}$, and a maximum depth of 3,800 $\mathrm{m}$. The Japan Sea is connected to other seas by shallow straits with the main water influx from the East China Sea through the Tsushima Strait ( 130 m sill depth) and outflow to the North Pacific through the Tsugaru Strait ( 130 m depth), the Sea of Okhotsk through the Soya (55 m depth) and Mamiya Straits ( 15 m depth)(Tada et al., 2013)(Figure 1.1). The shallow sill depths of these straights have significant influences on the present and ancient

oceanography of Japan Sea (Oba et al., 1991; Tada et al.,1999; Watanabe et al., 2007). At present, the only current that flows into the Japan Sea is the Tsushima Warm Current (TWC), which began 1.7 Mya (Itaki, 2016). 


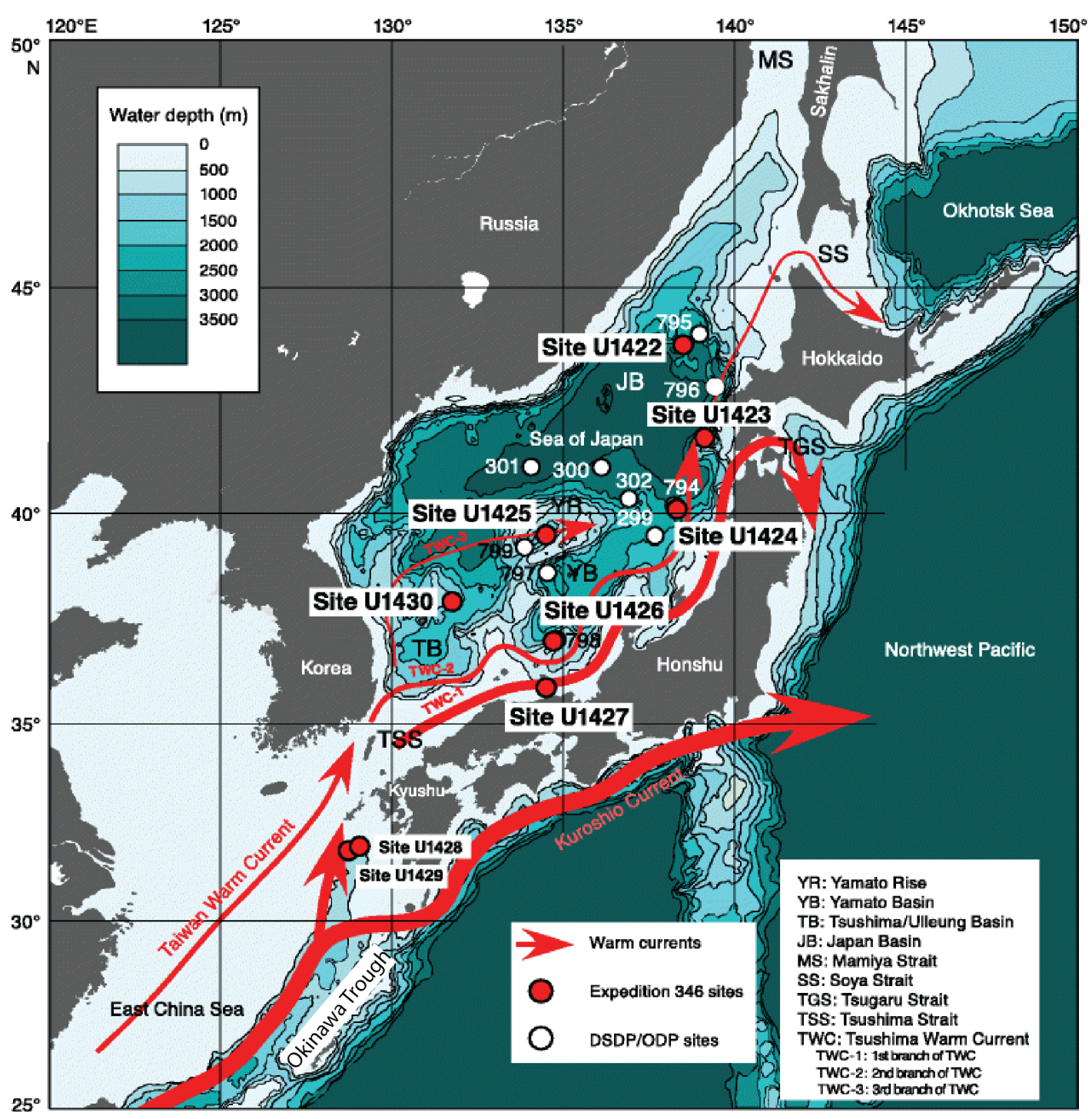

Figure 1.3. Bathymetric map of IODP Exp 346 (red circles) and previous DSDP/ODP (white circles) sampling site locations in the Japan Sea and East China Sea. Surface current systems are also shown (Modified from Tada et al., 2013).

The TWC, a branch of the Kuroshio Current, is formed in the East China Sea by mixing of the warm, saline Kuroshio Current and the nutrient-rich, less saline East China Sea Coastal Water (ECSCW)(Hase et al., 1999). Surface velocities range from 0.3 to 0.4 $\mathrm{m} \mathrm{s}^{-1}$ and the volume of flow in the Tsushima Strait varies from 1.1 to 2.6 Sv (Takikawa \& Yoon, 2005). The TWC separates into three branches after entering the Japan Sea 
(Hase et al., 1999). Most of the TWC flows out of the Tsugaru Strait to the Pacific Ocean while a portion of the TWC flows to the northern region of the Japan Sea (Gamo \& Horibe, 1983).

During glacial periods, eustatic sea level lowering had significant effects in oceanographic conditions within the Japan Sea, such as bottom water advection (Watanabe et al., 2007) and surface productivity (Oba et al., 1991; Tada et al., 1999), as a result of the shallow sill depths and near isolation of the Japan Sea from the East China Sea (Wang, 1999). Increased water column stratification occurred during these periods as a result of less saline, nutrient-rich water being the predominant influx to the area from the East China Sea (Tada et al., 1999; Watanabe et al., 2007). In comparison, increased sea levels during interglacial periods allow for increased current influx, not only increasing the volume of water flowing through the Tsushima Strait, but increasing nutrient flux from the East China Sea as well (Tada et al.,1999).

\subsubsection{East China Sea}

The East China Sea is a shallow, marginal sea consisting of an epicontinental shelf that breaks to the significantly deeper Okinawa Trough to the southeast. The East China Sea has an area greater than $770,000 \mathrm{~km}^{2}$, maximum shelf depth of $200 \mathrm{~m}$, and maximum Okinawa Trough depth of 2,700 $\mathrm{m}$ (Wong et al., 2000). The sea is surrounded by China, Taiwan, the Japanese archipelago, and the Korean peninsula and has an open exchange with the Bohai Sea, Yellow Sea, South China Sea, and Pacific Ocean and a limited exchange with the Japan Sea. The Yangtze and Yellow Rivers discharge 
significant amounts of freshwater, nutrients, and sediment to the East China Sea with increased discharge during East Asian Summer Monsoon (EASM) conditions (Anderson et al., 2018; Beny et al., 2018; Zhao et al., 2018).

Present ocean current conditions within the East China Sea are complex with numerous seasonal and permanent current flows, the most significant of which are the Kuroshio Current and the Chinese Coastal Water. The Kuroshio Current transports heat from lower latitudes through the South and East China Seas and eventually through the Pacific off the eastern coast of Japan (Wong et al., 2000). Although the Kuroshio Current is typically nutrient-poor, the Kuroshio Intermediate water is nutrient-rich and upwells in the Okinawa Trough (Chen, 1996). Before exiting the East China Sea, the Kuroshio Current branches into three segments with the majority of the current flowing out to the Pacific but with smaller volumes either entering the Japan Sea as the TWC or the Yellow Sea as the Yellow Sea Warm Current (Gallagher et al., 2015).

The East China Sea is also significantly impacted by differences between glacial and interglacial conditions. During glacial low stands, over one-half of the epicontinental shelf is exposed and both the Yangtze and Yellow Rivers migrate thousands of kilometers towards the Okinawa Trough (Saito et al., 1998). It would therefore be expected that significant terrestrial inputs would be preserved at Site U1429 during glacial periods. Interglacial periods, in comparison, typically show an expansion of the Chinese Coastal Water as a result of the increased precipitation and fluvial input into the western portion of the East China Sea (Gallagher et al., 2015). Presently, the path of the Kuroshio Current during glacial low stands is debated within the scientific community 
with some claiming a $3^{\circ}$ westerly migration (Gallagher et al., 2015) and others claiming that the Kuroshio Current does not enter the East China Sea at all (Ujiié \& Ujiié, 1999). At present, the Kuroshio Intermediate Water contributes more than three times the nutrient flux of the Chinese Coastal Water (Chen, 1995), so any significant reductions in the volume of the Kuroshio Current could potentially limit rates of primary productivity within surfaces waters.

\subsection{Review of Previous Research Efforts}

The East Asian Monsoon (EAM) affects large parts of India, China, Korea, and Japan both economically and climactically. The EAM is characterized by a southeasterly summer monsoon and northwesterly winter monsoon. Together, the two seasonal systems have a significant impact on the oceanography of the East Asian marginal seas (Tada, 2004). The EASM is characterized by warm and humid southerly winds that are created by the barometric gradient between the North Pacific High and the Asian Low (Yihui \& Chan, 2005). The EASM supplies a large amount of fresh water to the Yangtze and Yellow River deltas through increased precipitation over East Asia. The EASM therefore influences both the salinity and nutrient content of the surface waters of the East China Sea and the Japan Sea through the flow of the TWC through the Tsushima Strait (Kubota et al., 2010). In contrast, the East Asian Winter Monsoon (EAWM) is driven by pressure differences between the Siberian High and Aleutian Low during the winter and is characterized by dry and cold northerly winds and arid environments (Wang et al., 1999). These winter winds cool and mix the surface waters and enhance sea ice formation, 
which in turn helps drive the deep convection that ventilates the deep Japan Sea (Qian et al., 2002).

Previous studies have shown that sediments in the Japan Sea are of PlioPleistocene age ( $\sim 5 \mathrm{My})$ and are dominated by clay, silty clay, and diatom ooze with discrete foraminifera-rich clay layers and common tephra layers (Oba et al., 1991; Tada, 1994; Watanabe et al., 2007). Tada (1994) synthesized the results of ODP 127/128 drilling and developed the convention for lithologic units followed on IODP Expedition 346. Lithologic Unit I consists of Holocene to early Pleistocene silty clay and clay, with lesser amounts of diatom-bearing silty clay. Distinct color banding of alternating lightand dark-colored sediment is prevalent within Japan Sea sediments and are synchronous basin-wide (Tada et al., 2015). The pronounced centimeter to meter-scale color banding characteristic of Japan Sea sediments is largely restricted to this unit (Tada et al., 1992). Unit I is divided into two further subunits, IA and IB, where Subunit IB is characterized by a decrease in the number of the interbedded dark layers. Unit II (Pliocene) is differentiated from Unit I because of a significant increase in the diatom abundance and the absence of the color banding (Tada, 1994). 


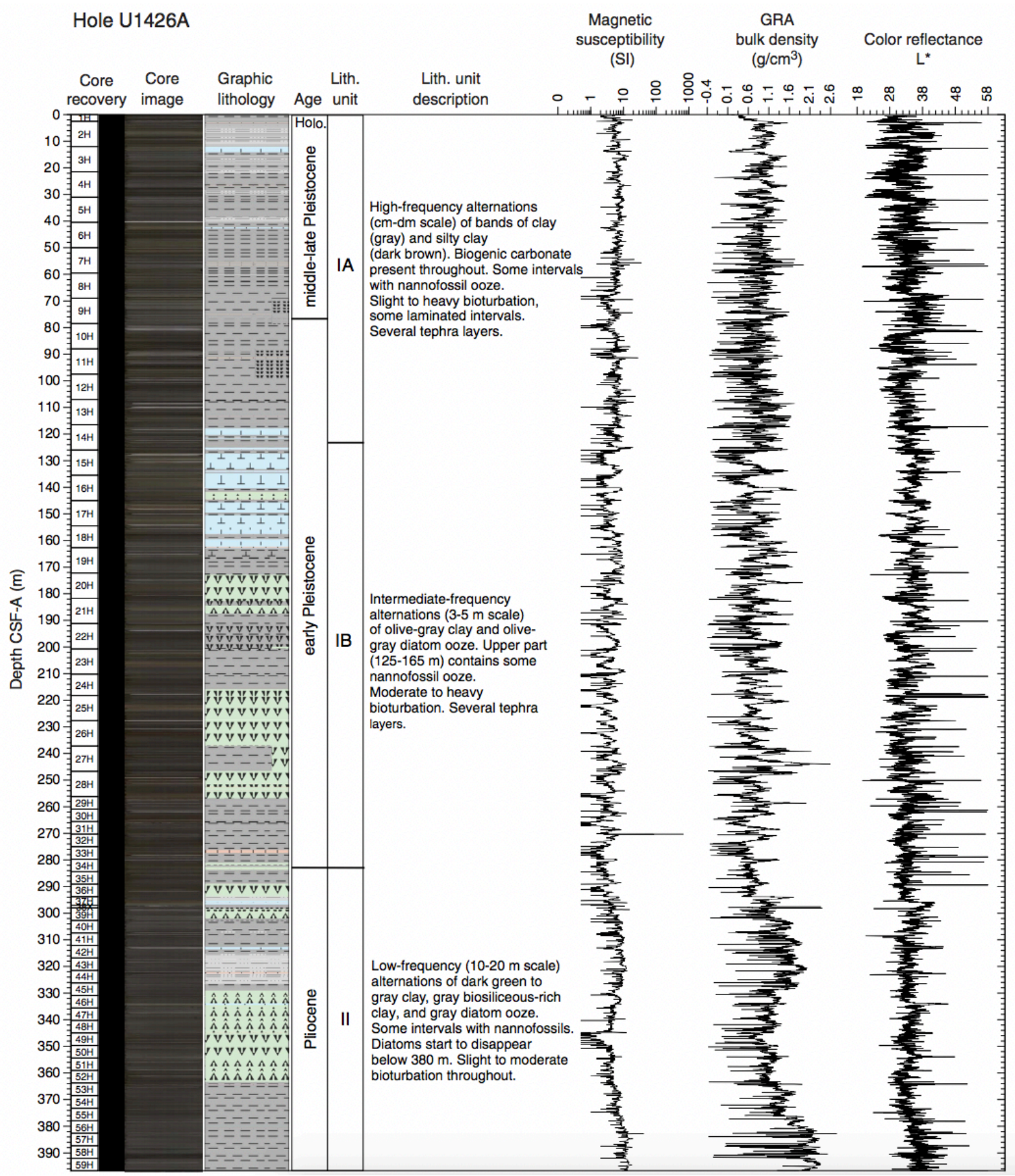

Figure 1.4. Lithographic units (IA, IB, and II) of Site U1426 sediments with core images, lithographic unit descriptions, magnetic susceptibility (SI), gamma ray attenuation (GRA) bulk density $\left(\mathrm{g} / \mathrm{cm}^{3}\right)$, and lightness ( $\left.\mathrm{L}^{*}\right)$ values. (Tada et al., 2015.)

Oba and Akasaka (1990) were among the first to comment on the characteristic lithologies present in the basin. They recognized two different types of dark layers in a sediment core from the southern Japan Sea. The first, a thick, laminated layer without 
benthic foraminifera and relatively thin laminated layers with limited benthic foraminiferal abundances that were dominated by Bolivina pacifica, a species tolerant of very low-oxygen concentrations (Oba et al., 1991; Oba \& Akasaka, 1990). The thick (140 $\mathrm{cm}$ ), dark layer is now known to record conditions during the Last Glacial Maximum (LGM; 20 ka)(Oba et al., 1995). The negative $\delta^{18} \mathrm{O}$ values recorded in planktonic foraminifera led Oba (1991) to suggest that these layers were deposited when the upper water column became stratified as a result of decreased sea levels and increased fluvial input. The strengthened stratification led to anoxic deep-water conditions with the presence of $\mathrm{H}_{2} \mathrm{~S}$, which is similar to present conditions in the Black Sea, and resulted in deposition of the thick, finely laminated, dark layer (Tada et al., 1992).

Changes in glacio-eustatic sea level possibly played a critical role during the LGM as the sill depth of the Tsushima Strait would have decreased to fewer than $20 \mathrm{~m}$, which would increase the proportion of freshwater compared to denser, saline influx (Oba et al., 1999). Although limited influx through the Tsushima Strait still occurred during the LGM, the predominant water flux to the Japan Sea was through precipitation and continental runoff (Tada et al., 1999). During the LGM, it was reported that increased water-column stratification resulted in the enrichment of redox-sensitive elements in the bottom sediments (Piper \& Isaacs, 1996) and significant Mo peaks (Crusius, 1999), both indicating anoxic bottom water. In two other cores from the Japan Sea, Masuzawa and Kitano (1984) found layers of pyrite and extremely high elemental sulfur concentrations during the LGM, which suggests that the pyrite-enriched layers were deposited as a result of $\mathrm{H}_{2} \mathrm{~S}$ bearing bottom waters. 
The thin centimeter- to decimeter-scale alternations of dark and light layers observed by Oba and Akasaka (1990) were later associated with Dansgaard-Oeschger cycles with the light organic-poor layers corresponding to cold stadial periods and the dark organic-rich layers correlated to warm interstadials (Tada et al., 1999; Tada, 2004). The occurrence of the foraminifera species Bolivina pacifica in some of the dark layers suggests that oxygen levels were greatly reduced $(<1.0 \mathrm{~mL} / \mathrm{L})$, but not completely anaerobic (Kato, 1992). On the basis of an increase in the relative abundance the diatom species Paralia sulcata, which is characteristic of the East China Sea Coastal Water (ECSCW), Tada (1999) argued that dark layer was deposited during an increase in the inflow of low-salinity, nutrient-rich ECSCW in comparison to the TWC. Increased ECSCW input would have increased the amount of surface productivity and inhibited vertical mixing as a result of increased salinity gradients accompanied with increased nutrient loads (Tada et al., 1999). They further argued that an increase in fluvial discharge from the Yangtze and Yellow Rivers in response to an enhanced EASM could lead to a greater contribution of the ECSCW to the TWC during interglacial and interstadial periods (Tada et al., 1999).

Observing the sediment fabrics in three sediment cores, Watanabe (2007) concluded that the variations between light and dark layers are related to deep-water oxygen levels. In the Japan Sea there are four different dark-layer fabrics and at least five different modes of deep-water circulation determined by the distribution and physical and chemical characteristics of the dark and light layers. Khim (2007) found elevated Mo/Al ratios and high concentrations of total sulfur (TS) associated with four of the thick dark 
layers which indicates sulfidic deep-water conditions. Tada (1992) also noted high TS peaks from ODP Site 797 and attributed them to abundant pyrite formation during glacial periods. These differing circulation modes were interpreted to reflect differing intensities of upwelling, productivity, and density stratification at different times (Tada et al., 1992). The preferential enrichment of these redox- sensitive elemental compositions are likely the result of the formation of sulfides or their transformation into reduced, less soluble forms (Calvert \& Pedersen, 1993; Piper \& Isaacs, 1996). Not all dark layers are associated with enrichments of Mo and TS, however, which suggests that at least some of the dark layers found in the Japan Sea are associated with suboxic conditions where some oxygen remains (Khim et al., 2007), which may indicate a different component of formation.

Within the Japan Sea, complex relationships exist between sea level, monsoonal dynamics (EASM precipitation; EAWM wind intensity), ocean currents (TWC vs ECSCW), paleoproductivity (nutrient loads and upwelling), winter cooling and deepwater production (EAWM), and the resulting sediment deposition (organic fluxes and preservation). Constraints will need to be placed on these variables to develop a better understanding of the dark and light layers in the sedimentary record in addition to the overall paleoceanographic setting of the Japan Sea. 


\subsection{IODP Expedition 346}

Integrated Ocean Drilling Program (IODP) Expedition 346 had a primary objective of collecting continuous sedimentary sequences to reconstruct the EAM by its major components (EASM, EAWM, and westerly jet axis) on orbital- to millennialtimescales and to determine when the EAM began. The EAM currently affects the water supply of over one-third of the global population living in East Asia through periods of intense precipitation and increased aridity. To better assess the future needs of these vulnerable populations due to climate change, Expedition 346 collaborations will attempt to better understand the complex ocean-atmospheric circulation of the region over recent geologic time. Expedition 346 drilling objectives were successfully completed with the retrieval of relatively continuous sedimentary cores in seven sampling sites in the Japan Sea and two sampling sites in the East China Sea during the summer of 2013 (Tada et al., 2015). Related scientific goals for Expedition 346 were to reconstruct the surface and deep-water circulation patterns and surface productivity in the Japan Sea over at least the last five million years as well as any variation in past changes in the EAM and glacioeustatic sea level (Tada et al., 2013).

The Japan Sea experienced significant variation between glacial and interglacial time periods due to the shallow, narrow straits that connect it to the other water bodies. During interglacial periods, influx of oceanic currents from the East China Sea leads to increased dissolved oxygen concentrations within the water column and higher nutrient loads. Glacial periods, however, led to the near isolation of the Japan Sea, resulting in depleted dissolved oxygen and limited nutrient flux. Both the water circulation patterns 
and surface productivity are strongly affected not only by oceanic influx, but EAM intensities as well. The IODP Expedition 346 was the first scientific drilling focused exclusively on the climate system of the area with previous Ocean Drilling Program (ODP) Legs 127 and 128 focusing on the tectonic and paleoceanographic history.

The current study focuses on three Expedition 346 sites: Sites U1426 and U1427 in the Japan Sea and Site U1429 in the East China Sea (Figure 1.3). Site U1426 is in the Yamato Basin near the top of the Oki Ridge. It is located at the same location as ODP Site $798\left(37^{\circ} 2.00^{\prime} \mathrm{N}, 134^{\circ} 48.00^{\prime} \mathrm{E}\right)$ and at a depth of 903 meters below sea level (mbsl). Site U1426 is under the influence of the second branch of the TWC. Previous studies have shown an average sedimentation rate of $\sim 80 \mathrm{~m} / \mathrm{My}$ (Tada et al., 2013). Site U1426 has the longest record of the three sites studied, spanning over 1.3 My (Sagawa et al., 2018).

Site U1427 is also in the Yamato Basin near the outer margin of the continental shelf near the coast of Honshu Island. It is located at $35^{\circ} 57.92^{\prime} \mathrm{N}, 134^{\circ} 26.06^{\prime} \mathrm{E}$, is the shallowest site at $330.3 \mathrm{mbsl}$, and is under the influence of the first branch of the TWC. A study core suggests a sedimentation rate of $\sim 300 \mathrm{~m} / \mathrm{My}$ which would provide a very highresolution record of paleoceanographic events (Tada et al., 2013). The shallow depth of Site U1427 implies that it has likely always been located above the calcite compensation depth (CCD) in the Japan Sea (> $2000 \mathrm{~m}$ depth; Lee et al., 2000) and was expected to have high carbonate preservation. 
Site U1429 is located in the northernmost part of the East China Sea in the Danjo Basin of the Okinawa Trough at $31^{\circ} 37.04^{\prime} \mathrm{N}, 128^{\circ} 59.85^{\prime} \mathrm{N}$ and $732 \mathrm{mbsl}$. It receives significant contributions from the Yangtze and Yellow Rivers, which supply high concentrations of terrestrial organic matter. During glacial low stands, a significant portion of the continental shelf is exposed and the Yangtze and Yellow Rivers migrate towards the Okinawa Trough (Tada et al., 2013). Site U1429 is under the influence of the TWC after it branches from the Kuroshio Current and the nutrient-rich ECSCW (Gallagher et al., 2015). Previous studies have shown high sedimentation rates between 300-800 m/My. (Kubota et al. 2010), which will also allow a very high-resolution reconstruction.

Sediments recovered during drilling were fine-grained siliciclastics with distinct light/dark sedimentary cycles. The dark layers were mostly laminated while the light layers were homogeneous to bioturbated (Tada et al., 2015). The meter-scale alternations in the light and dark sedimentary units record orbital-scale variations in surface and deepwater circulations, whereas centimeter-scale alternations in the light and dark sequences record millennial-scale climatic oscillations (Tada et al., 2018). Tada (1992) further demonstrated the light/dark sedimentary cycles were synchronous basin-wide and that they can be correlated between sites within the study area.

Lowering of glacio-eustatic sea level during glacial low stands limited influx through the Tsushima Straight causing suboxic to anoxic bottom water conditions, which are associated with thick, organic-rich, dark sedimentary layers. With decreased input from the TWC, a low-salinity surface layer developed, which limited deep-water 
ventilation because of increased water column stratification (Oba et al., 1991). Thick, light-colored layers are associated with oxic conditions during interglacial high stands when there was a significant influx of the TWC through the Tsushima Strait (Tada et al., 1999). Thin dark and light layers are associated with multiple productivity and bottom water oxygenation conditions as the relative contribution of the TWC and ECSCW varied throughout time (Tada, 2004).

\subsection{Objectives}

The primary goal of the present study was to use elemental and stable isotope geochemical analyses to establish a high-resolution paleoceanographic and paleoproductivity reconstruction for the Japan Sea and East China Sea systems. Distinct differences between glacial and interglacial periods were present as the type and volume of oceanic currents flowing through the Tsushima Strait vary with glacio-eustatic sea level changes. This study focused on marine sediment cores obtained from IODP Expedition 346 that will serve as records of nutrient fluxes, organic matter source changes, and current dynamics since the Late Pleistocene. Developing a better understanding of current influx, circulation modes, and surface paleoproductivities throughout the recent geological past will lead to a more thorough understanding of the EAM variability, especially conditions associated with increased EASM precipitation and nutrient flux. The following objectives will be addressed in successive chapters: 
1. To determine how glacial/interglacial cycles affected the paleoceanographic conditions of the Japan Sea, specifically how glacial low stands and interglacial high stands impacted the inflow of the TWC and ECSCW and the resulting primary productivity levels in surface waters at Site U1427.

1a: Determine the sill depth of water flowing through the Tsushima Strait during the 350,000 year record at Site U1427 in the Japan Sea.

1b: Determine the rates of paleoproductivity throughout the sedimentary record of Site $\mathrm{U} 1427$ using $\mathrm{CaCO}_{3}, \mathrm{TOC}, \mathrm{TN}, \delta^{13} \mathrm{C}$, and $\delta^{15} \mathrm{~N}$ geochemical data.

1c: Compare rates of paleoproductivity with sill depth of water in the Tsushima Strait between glacial and interglacial periods.

2. To compare the geochemical records from Site U1426 in the Japan Sea before and after the Mid- Pleistocene Transition (MPT; 700-1200 ka) to better understand the correlation between orbital frequencies and relative paleoproductivity cycles.

2a: Determine rates of paleoproductivity at Site U1426 in the Japan Sea during glacial and interglacial periods using $\mathrm{CaCO}_{3}, \mathrm{TOC}, \mathrm{TN}, \delta^{13} \mathrm{C}$, and $\delta^{15} \mathrm{~N}$ geochemical data.

2b: Calculate the orbital frequencies and heterodynes within the paleoproductivity records using continuous wavelet and multi-taper method (MTM) spectral analyses.

2c: Determine how dominant orbital frequencies and heterodynes shift during and after the MPT within Japan Sea sediments. 
3. To understand how glacial/interglacial cycles affected the paleoceanographic conditions of the East China Sea, specifically how high and low stands impacted upwelling timing and intensity of the Kuroshio Current.

3a: Determine rates of paleoproductivity at Site U1429 in the East China Sea during glacial and interglacial periods using $\mathrm{CaCO}_{3}, \mathrm{TOC}, \mathrm{TN}, \delta^{13} \mathrm{C}$, and $\delta^{15} \mathrm{~N}$ geochemical data.

3b: Qualitatively reconstruct Kuroshio Current flux in the East China Sea during glacial periods.

3c: Examine interbedded sand layers within the sedimentary record of Site U1429.

\subsection{REFERENCES}

Altabet, M.A., Murray, D.W., \& Prell, W.L. (1999). Climatically linked oscillations in Arabian Sea denitirification over the past 1 m.y.: Implications for the marine $\mathrm{N}$ cycle. Paleoceanography, 14(6), 732-743.

https://doi.org/10.1029/1999PA900035

Altabet, M.A., Higginson, M.J., \& Murray, D.W. (2002). The effect of millennial-scale changes in Arabian Sea denitrification on atmospheric $\mathrm{CO}_{2}$. Nature, 415, 159162. https://doi.org/10.1038/415159a

Anderson, C.H., Murray, R.W., Dunlea, A.G., Giosan, L., Kinsley, C.W., McGee, D., et al. (2018). Climatically Driven Changes in the Supply of Terrigenous Sediment to the East China Sea. Geochemistry, Geophysics, Geosystems, 19, 1-15. https://doi.org/10.1029/2017GC007339

Arndt, S., Jørgensen, B.B., LaRowe, D.E., Middelburg, J.J., Pancost, R.D., \& Regnier, P. (2013). Quantifying the degradation of organic matter in marine sediments: A review and synthesis. Earth-Science Reviews, 123, 53-86.

https://doi.org/10.1016/j.earscirev.2013.02.008

Ballantyne, F., Menge, D.N.L., Ostling, A., \& Hosseini, P. (2008). Nutrient recycling affects autotroph and ecosystem stoichiometry. The American Naturalist, 171(4), 511-523. https://doi.org/10.1086/528967 
Beny, F., Toucanne, S., Skonieczny, C., Bayon, G., \& Ziegler, M. (2018). Geochemical provenance of sediments from the northern East China Sea document a gradual migration of the Asian Monsoon belt over the past 400,000 years. Quaternary Science Reviews, 190, 161-175. https://doi.org/10.1016/j.quascirev.2018.04.032

Berger, W.H. \& Wefer, G. (2002). On the reconstruction of upwelling history: Namibia upwelling in context. Marine Geology, 180, 3-28. https://doi.org/10.1016/S00253227(01)00203-1

Berner, R.A. (1989). Biogeochemical cycles of carbon and sulfur and their effect on atmospheric oxygen over Phanerozoic time. Global and Planetary Change, 75, 97-122. https://doi.org/10.1016/0921-8181(89)90018-0

Brasier, M.D. (1995). Fossil indicators of nutrient levels. 1: Eutrophication and climate change. Geological Society, London, Special Publications, 83, 113-132. https://doi.org/10.1144/GSL.SP.1995.083.01.07

Calvert, S.E. \& Pedersen, T.F. (1993). Geochemistry of recent oxic and anoxic marine sediments: Implications for the geological record. Marine Geology, 113, 67-88. https://doi.org/10.1016/0025-3227(93)90150-T

Canuel, E.A. \& Martens, C.S. (1996). Reactivity of recently deposited organic matter: Degradation of lipid compounds near the sediment-water interface. Geochemica et Cosmochimica Acta, 60(10), 1793-1806. https://doi.org/10.1016/00167037(96)00045-2

Chen, C.A. (1996). The Kuroshio Intermediate Water is the major source of nutrients on the East China Sea continental shelf. Oceanologica Acta, 19, 523-527.

Cline, J.D. \& Kaplan, I.R. (1975). Isotopic fractionation of dissolved nitrate during denitrification in the eastern tropical north Pacific Ocean. Marine Chemistry, 3(4), 271-299. https://doi.org/10.1016/0304-4203(75)90009-2

Covino, T. (2017). Hydrologic connectivity as a framework for understanding biogeochemical flux through watersheds and along fluvial networks. Geomorphology, 277, 133-144. https://doi.org/10.1016/j.geomorph.2016.09.030

Crusius, J. (1999). A 36 kyr geochemical record from the Sea of Japan of organic matter flux variations and changes in intermediate water oxygen concentrations.

Paleoceanography, 14(2), 248; 248-259; 259. https://doi.org/10.1029/1998PA900023

Dave, A.C. \& Lozier, M.S. (2010). Local stratification control of marine productivity in the subtropical North Pacific. Journal of Geophysical Research: Oceans, 115, 116. https://doi.org/10.1029/2010JC006507 
Falkowski, P.G., Barber, R.T., \& Smetacek, V. (1998). Biogeochemical controls and feedbacks on ocean primary production. Science, 281(5374), 200-206.

https://doi.org/10.1126/science.281.5374.200

Fry, B. \& Sherr, E.B. (1984). ${ }^{13}$ C measurements as indicators of carbon flow in marine and freshwater ecosystems. Contributions in Marine Science, 27, 13-47. DOI: 10.1007/978-1-4612-3498-2_12

Gallagher, S.J., Kitamura, A., Iryu, Y., Itaki, T., Koizumi, I., \& Hoiles, P. W. (2015). The Pliocene to recent history of the Kuroshio and Tsushima Currents: A multi-proxy approach. Progress in Earth and Planetary Science, 2(1), 17. https://doi.org/10.1186/s40645-015-0045-6

Gamo, T. \& Horibe, Y. (1983). Abyssal circulation in the Japan Sea. Journal of the Oceanographical Society of Japan, 39(5), 220-230.

https://doi.org/10.1007/BF02070392

Geider, R.J. \& La Roche, J. (2002). Redfield revisited: Variability of C:N:P in marine microalgae and its biochemical basis. European Journal of Phycology, 37, 1-17. https://doi.org/10.1017/S0967026201003456

Harvey, R., Tuttle, J.H., \& Bell, T.J. (1995). Kinetics of phytoplankton decay during simulated sedimentation: Changes in biochemical composition and microbial activity under oxic and anoxic conditions. Geochimica et Cosmochimica Acta, 59(16), 3367-3377. https://doi.org/10.1016/0016- 7037(95)00217-N

Hase, H., Yoon, J.H., \& Koterayama, W. (1999). The current structure of the Tsushima Warm Current along the Japanese coast. Journal of Oceanography, 55(2), 217 235. https://doi.org/10.1023/A:1007894030095

Hedges, J.I. \& Keil, R.G. (1995). Sedimentary organic matter preservation: An assessment and speculative synthesis. Marine Chemistry, 49, 81-115. https://doi.org/10.1016/0304- 4203(95)00008-F

Hulthe, G., Hulth, S., \& Hall, P.O.J. (1998). Effect of oxygen on degradation rate of refractory and labile organic matter in continental margin sediments. Geochimica et Cosmochimica Acta, 62(8), 1319-1328. https://doi.org/10.1016/S00167037(98)00044-1

Itaki, T. (2016). Transitional changes in microfossil assemblages in the Japan Sea from the Late Pliocene to Early Pleistocene related to global climatic and local tectonic events. Progress in Earth and Planetary Science, 3(1), 11. https://doi.org/10.1186/s40645-016-0087-4 
Jickells, T.D. (1998). Nutrient biogeochemistry of the coastal zone. Science, 281(5374), 217-222. DOI:10.1126/science.281.5374.217

Kato, M. (1992). Benthic foraminifera from the Japan Sea: Leg 128. Proceedings of the Ocean Drilling Program Scientific Results, 127/128, 365-392. https://doi.org/10.2973/odp.proc.sr.127128-1.142.1992

Khim, B.K., Bahk, J.J., Hyun, S., \& Lee, G.H. (2007). Late Pleistocene dark laminated mud layers from the Korea Plateau, western East Sea/Japan Sea, and their paleoceanographic implications. Palaeogeography, Palaeoclimatology, Palaeoecology, 247(1-2), 74-87. https://doi.org/10.1016/j.palaeo.2006.11.029

Kubota, Y., Kimoto, K., Tada, R., Oda, H., Yokoyama, Y., \& Matsuzaki, H. (2010). Variations of East Asian Summer Monsoon since the last deglaciation based on $\mathrm{Mg} / \mathrm{Ca}$ and oxygen isotope of planktic foraminifera in the northern East China Sea. Paleoceanography, 25(4). https://doi.org/10.1029/2009PA001891

Lee, G.H., Park, S.C., \& Kim, D.C. (2000). Fluctuations of the calcite compensation depth (CCD) in the East Sea (Sea of Japan. Geo-Marine Letters, 20(1), 20-26. https://doi.org/10.1007/s003670000029

Lehmann, M.F., Bernasconi, S.M., Barbieri, A., \& McKenzie, J.A. (2002). Preservation of organic matter and alteration of its carbon and nitrogen isotope composition during simulated and in situ early sediment diagenesis. Geochimica et Cosmochimica Acta, 66(20), 3573-3584. https://doi.org/10.1016/S00167037(02)00968-7

Mariotti, A., Germon, J.C., Leclerc, A., Catroux, G., Letolle, R. (1982). Experimental determination of kinetic isotope fractionation of nitrogen isotopes during denitrification. In K. Schmidt, H.L., Forstel, H., Heinzinger (Ed.), Stable Isotopes, 413-430.

Masuzawa, T. \& Kitano, Y. (1984). Appearance of $\mathrm{H}_{2} \mathrm{~S}$-bearing bottom waters during the last glacial period in the Japan Sea. Geochemical Journal, 18, 167-172. https://doi.org/10.2343/geochemj.18.167

Meyers, P.A. (1994). Preservation of elemental and isotopic source identification of sedimentary organic matter. Chemical Geology, 114(3-4), 289-302. https://doi.org/10.1016/0009- 2541(94)90059-0

Meyers, P.A. (1997). Organic geochemical proxies of paleoceanographic, paleolimnologic, and paleoclimatic processes. Organic Geochemistry, 27, 213250. https://doi.org/10.1016/S0146-6380(97)00049-1 
Montoya, J.P., Horrigan, S.G., \& McCarthy, J.J. (1991). Rapid, storm-induced changes in the natural abundance of ${ }^{15} \mathrm{~N}$ in planktonic ecosystem, Chesapeake Bay, USA.

Geochemica et Cosmochimica Acta, 553, 3627-3638.

https://doi.org/10.1016/0016-7037(91)90060-I

Moore, C.M., Mills, M.M., Arrigo, K.R., Berman-Frank, I., Bopp, L., Boyd, P. W., et al., (2013). Processes and patterns of oceanic nutrient limitation. Nature Geoscience, 6, 701-710. https://doi.org/10.1038/ngeo1765

Müller, P.J. \& Suess, E. (1979). Productivity, sedimentation rate, and sedimentary organic matter in the oceans- I. Organic carbon preservation. Deep Sea Research Part A, Oceanographic Research Papers, 26(12), 1347-1362. https://doi.org/10.1016/0198-0149(79)90003-7

O’Leary, M.H. (1981). Carbon isotope fractionation in plants. Phytochemistry, 20, 553567. https://doi.org/10.1016/0031-9422(81)85134-5

Oba, T., Kato, M., Kitazato, H., Koizumi, I., Omura, A., Sakai, T., \& Takayama, T. (1991). Paleoenvironmental changes in the Japan Sea during the last 85,000 years. Paleoceanography, 6(4), 499-518. https://doi.org/10.1029/91PA00560

Oba, T. \& Akasaka, N. (1990). Paleoenvironmental change of the Japan Sea based on organic carbon contents of two piston cores. Quaternary Research (Tokyo). https://doi.org/10.1007/s11248-005-5877-1

Oba, T., Murayama, M., Matsumoto, E., \& Nakamura, T. (1995). AMS- ${ }^{14}$ C Ages of Japan Sea Cores from the Oki Ridge. The Quaternary Research (DaiyonkiKenkyu), 34(4), 289-296. https://doi.org/10.4116/jaqua.34.4_289

Peterson, B.J. \& Howarth, R.W. (1987). Sulfur, carbon, and nitrogen isotopes used to trace organic matter flow in the salt-marsh estuaries of Sapelo Island, Georgia. Limnology and Oceanography, 32(6), 1195-1213. https://doi.org/10.4319/1o.1987.32.6.1195

Piper, D.Z. \& Isaacs, C.M. (1996). Instability of bottom-water redox conditions during accumulation of Quaternary sediment in the Japan Sea. Paleoceanography, 11(2), 171- 190. https://doi.org/10.1029/95PA03553

Pomeroy, L.R. (1974). The ocean's food web, a changing paradigm. BioScience, 24(9), 499-504. https://doi.org/10.2307/1296885

Qian, W., Kang, H.S., \& Lee, D.K. (2002). Distribution of seasonal rainfall in the East Asian Monsoon region. Theoretical and Applied Climatology, 73, 151-168. https://doi.org/10.1007/s00704-002-0679-3 
Sagawa, T., Nagahashi, Y., Satoguchi, Y., Holbourn, A., Itaki, T., Gallagher, S.J., et al. (2018). Integrated tephrostratigraphy and stable isotope stratigraphy in the Japan Sea and East China Sea using IODP Sites U1426, U1427 and U1429, Expedition 346 Asian Monsoon. Progress in Earth and Planetary Science, 5(18). https://doi.org/10.1186/s40645-018- 0168-7

Saito, Y., Katayama, H., Ikehara, K., Kato, Y., Matsumoto, E., Oguri, K., et al. (1998). Transgressive and highstand systems tracts and post-glacial transgression, the East China Sea. Sedimentary Geology, 122, 217-232.

Sato, N. \& Moriyama, T. (2018). Photosynthesis. In Cyanidioschyzon merolae: A New Model Eukaryote for Cell and Organelle Biology. Singapore: Springer. 263-281.

Schubert, C.J. \& Calvert, S.E. (2001). Nitrogen and carbon isotopic composition of marine and terrestrial organic matter in Arctic Ocean sediments: Implications for nutrient utilization and organic matter composition. Deep-Sea Research Part I: Oceanographic Research Papers, 48(3), 789-810. https://doi.org/10.1016/S09670637(00)00069-8

Stein, R. (1991). Accumulation of organic carbon in marine sediments. In Lecture Notes in Earth Sciences. Berlin: Springer.

Tada, R., Irino, T., \& Koizumi, I. (1999). Land-ocean linkages over orbital and millennial timescales recorded in Late Quaternary sediments of the Japan Sea. Paleoceanography, 14(2), 236-247. https://doi.org/10.1029/1998PA900016

Tada, R., Koizumi, I., Cramp, A., \& Rahman, A. (1992). Correlation of dark and light layers, and the origin of their cyclicity in the Quaternary sediments from the Japan Sea. Proceedings of the Ocean Drilling Program Scientific Results, 127, 577-601. DOI: 10.2973/odp.proc.sr.127128-1.160.1992

Tada, R., Murray, R.W., Alvarez Zarikian, C.A., Anderson, W.T., Brace, B.J., et al. (2015). Expedition 346 Summary. Proceedings of the Ocean Drilling Program, 346. doi:10.2204/iodp.proc.346.101.2015

Tada, R. (1994). Paleoceanographic evolution of the Japan Sea. Palaeogeography, Palaeoclimatology, Palaeoecology, 108(3-4), 487-508. https://doi.org/10.1016/0031- 0182(94)90248-8

Tada, R. (2004). Onset and evolution of millennial-scale variability in the Asian Monsoon and its impact on paleoceanography of the Japan Sea. In Geophysical Monograph Series (Vol. 149, pp. 283-298). https://doi.org/10.1029/149GM15

Tada, R. (2013). Scientific Prospectus (Integrated Ocean Drilling Program), 346. doi:10.2204/iodp.sp.346.2013 
Tada, R., Irino, T., Ikehara, K., Karasuda, A., Sugisaki, S., Xuan, C., et al. (2018). Highresolution and high-precision correlation of dark and light layers in the Quaternary hemipelagic sediments of the Japan Sea recovered during IODP Expedition 346. Progress in Earth and Planetary Science, 5(19). https://doi.org/10.1186/s40645-018-0167-8

Takikawa, T. \& Yoon, J.H. (2005). Volume transport through the Tsushima Straits estimated from sea level difference. Journal of Oceanography, 61(4), 699-708. https://doi.org/10.1007/s10872-005-0077-4

Teece, M.A., Getliff, J.M., Leftley, J.W., Parkes, R.J., \& Maxwell, J.R. (1998). Microbial degradation of the marine prymnesiophyte Emiliania huxleyi under oxic and anoxic conditions as a model for early diagenesis: Long chain alkadienes, alkenones and alkyl alkenoates. Organic Geochemistry, 29(4), 863-880. https://doi.org/10.1016/S0146- 6380(98)00145-4

Trumper, K., Bertzky, M., Dickson, B., van Der Heijden, G., Jenkins, M., \& Manning, P (2009). The natural fix? The role of ecosystems in climate mitigation. A UNEP rapid response assessment. UNEP-WCMC.

Ujiié, H. \& Ujiié, Y. (1999). Late Quaternary course changes of the Kuroshio Current in the Ryukyu Arc region, northwestern Pacific Ocean. Marine Micropaleontology, 37(1), 23-40. https://doi.org/10.1016/S0377-8398(99)00010-9

Wang, L., Sarnthein, M., Erlenkeuser, H., Grimalt, J., Grootes, P., Heilig, S., et al. (1999). East Asian Monsoon climate during the Late Pleistocene: High-resolution sediment records from the South China Sea. Marine Geology, 156, 245-284. https://doi.org/10.1016/S0025-3227(98)00182-0

Wang, P. (1999). Response of Western Pacific marginal seas to glacial cycles: Paleoceanographic and sedimentological features. Marine Geology, 156(1-4), 539. https://doi.org/10.1016/S0025-3227(98)00172-8

Watanabe, S., Tada, R., \& Ikehara, K. (2007). Sediment fabrics, oxygenation history, and circulation modes of Japan Sea during the Late Quaternary. Palaeogeography, Palaeoclimatology, Palaeoecology, 247, 50-64. https://doi.org/10.1016/j.palaeo.2006.11.021

Wong, G.T.F., Chao, S.Y., Li, Y.H., \& Shiah, F.K. (2000). The Kuroshio Edge Exchange Processes (KEEP) study - An introduction to hypotheses and highlights. Continental Shelf Research, 20, 335-347. https://doi.org/10.1016/S02784343(99)00075-8 
Yihui, D. \& Chan, J.C.L. (2005). The East Asian Summer Monsoon: An overview. Meteorology and Atmospheric Physics, 89, 117-142.

https://doi.org/10.1007/s00703-005-0125-z

Yu, Z., Wang, X., Han, G., Liu, X., \& Zhang, E. (2018). Organic and inorganic carbon and their stable isotopes in surface sediments of the Yellow River Estuary. Scientific Reports, 8(1), 10825. https://doi.org/10.1038/s41598-018-29200-4

Zhao, D., Wan, S., Toucanne, S., Clift, P.D., Tada, R., Révillon, S., et al. (2017). Distinct control mechanism of fine-grained sediments from Yellow River and Kyushu supply in the northern Okinawa Trough since the last glacial. Geochemistry, Geophysics, Geosystems, 18(8). https://doi.org/10.1002/2016GC006764

Zhao, D., Wan, S., Clift, P.D., Tada, R., Huang, J., Yin, X., et al. (2018). Provenance, sea-level and monsoon climate controls on silicate weathering of Yellow River sediment in the northern Okinawa Trough during late last glaciation.

Palaeogeography, Palaeoclimatology, Palaeoecology, 490, 227-239. https://doi.org/10.1016/j.palaeo.2017.11.002 


\section{CHAPTER 2: PALEOPRODUCTIVITY HISTORY OF THE JAPAN SEA OVER THE LAST 350,000 YEARS ${ }^{2}$}

\subsection{Abstract}

During Quaternary glacio-eustatic sea level changes, the paleoceanographic conditions in the Japan Sea varied markedly as a result of the shallow, narrow straits connecting the sea to surrounding waters, limiting the influx of oceanic currents. During glacial sea level low stands the sea was nearly isolated, creating a highly-stratified water column and hypoxic to anoxic bottom water conditions. During sea level high stands, the Tsushima Warm Current flowed into the sea, bringing warm, high-salinity water, which led to vertical mixing and oxic conditions. The present study uses the geochemical $\left(\mathrm{CaCO}_{3}, \mathrm{TOC}, \mathrm{N}, \delta^{13} \mathrm{C}\right.$, and $\left.\delta^{15} \mathrm{~N}\right)$ and foraminiferal analyses of IODP (Integrated Ocean Drilling Program) Site U1427 in the Japan Sea to document the role of upwelling and paleoproductivity variations. The analyses suggest enhanced productivity typified interglacial periods, possibly as a result of increased upwelling and deep-water ventilation. However, during glacial periods in the Japan Sea, the sea was partially isolated and the limited influx through the Tsushima Strait resulted in decreased primary productivity in the surface waters.

\footnotetext{
2 To be submitted to Paleoceanography and Paleoclimatology. Black, H.D., Anderson, W.T., Gallagher, S.J., Sagawa, T., and Tada, R.
} 


\subsection{Introduction}

Glacio-eustatic sea level variation can have a significant control on the rates of

primary productivity occurring in surface waters of the Japan Sea as the sea can be nearly isolated during glacial low stands. Increasing oceanic influx through the Tsushima Strait that connects the Japan Sea to the East China Sea not only increases the volume of water moving through the strait but also causes a variation in surface salinities and nutrient concentrations as well (Tada et al., 1999; Watanabe et al., 2007). Depending on the relative contribution of the Tsushima Warm Current (TWC) and East China Sea Coastal Water (ECSCW), oxic to euxinic bottom water conditions developed depending on the salinity, water density, and degree of vertical mixing within the water column (Tada et al., 1999; Watanabe et al., 2007). The complex interaction of oceanographic conditions in the Japan Sea and the relative contribution of the TWC and ECSCW influx (and their respective nutrient loads) led to varying relative primary productivity rates throughout the Pleistocene (Tada et al., 1992, 1994, 1999, 2004).

Sediment records from marginal seas typically contain both marine and terrestrial materials and have a more sensitive response to climatic changes and higher sedimentation rates than open-ocean environments. The present oceanographic conditions of the marginal Japan Sea are actively controlled by the type and relative contribution of water flowing through the narrow, shallow Tsushima Strait (Tada et al., 1999). It is therefore expected that major glacio-eustatic sea level changes could have caused significant changes in the influx, salinity, and nutrient load of water entering the Japan Sea, which could affect paleoceanographic conditions such as productivity and deep- 
water ventilation (Gallagher et al., 2018; Oba et al., 1991; Tada et al., 1999; Watanabe et al., 2007).

Previous scientific drilling expeditions have occurred in the Japan Sea to understand the tectonic evolution of the area including the Deep Sea Drilling Program (DSDP) Leg 31 and Ocean Drilling Program (ODP) Legs 127 and 128, which allowed extensive analysis of Quaternary paleoceanography of the marginal sea. However, Integrated Ocean Drilling Program (IODP) Expedition 346 was the first expedition to focus exclusively on the climate dynamics which will develop a better understanding of the oceanic-atmospheric circulations in the system and how they have responded to previous, and therefore potential future, climate changes (Tada et al., 2015).

The current study focuses on the isotopic and elemental concentrations of organic carbon, total nitrogen, calcium carbonate concentrations and planktic and benthic foraminiferal abundances to better understand the role of glacio-eustatic sea level variation and the effects on paleoproductivity in the Japan Sea. Carbon and nitrogen are essential in primary productivity since they compose a large proportion of plant and animal tissues (Stevenson \& Cole, 1999). Changes in physiochemical conditions, such as temperature, salinity, light penetration, and nutrient loads, in marine environments can alter the concentration of photosynthesis in the photic zone, and therefore the rate of primary productivity occurring at the surface (Sato \& Moriyama, 2018). The isotopic ratios of these elements are also affected by changes in surface productivity and other parameters, such as biologic and kinetic fractionations (Fry \& Sherr, 1984; Peterson \& Howarth, 1987; Peterson \& Fry, 1987). 
Organic matter produced at the surface of the water eventually sinks and settles at the sea floor where it is either diagenetically altered or stored in the sediment (Lehmann et al., 2002). Although only a small proportion of the organic matter produced at the surface is preserved in the sedimentary record, it has been shown that the preserved sediment is typically geochemically representative of the original organic matter (Emerson \& Hedges, 1988; Meyers, 1994). The organic matter content of sediment has been shown to be representative of the productivity, where increased productivity in the surface waters leads to increased organic matter preserved (Finney et al., 1988; Müller \& Suess, 1979; Pedersen, 1983).

Carbon and nitrogen isotopes not only can be used to determine organic matter source areas, i.e., terrestrial vs marine (Meyers, 1997; Schubert \& Calvert, 2001), but can also indicate changes in past productivity variations (Calvert et al., 1992; Minoura et al., 1997; Wada et al., 1990). As primary productivity increases in the surface waters of oligotrophic environments, biologically limiting nutrients such as $\mathrm{N}$ and $\mathrm{P}$ concentrations decrease as a result of increased nutrient utilization. Increasing primary production would be expected to lead to increases in the concentration of organic carbon and nitrogen enriched $\delta^{13} \mathrm{C}$ and $\delta^{15} \mathrm{~N}$ values (Calvert et al., 1992; Müller \& Suess, 1979). Isotopically enriched $\delta^{15} \mathrm{~N}$ values are potentially suggesting dissolved inorganic nitrogen limitation in the surface waters as a result of increased primary productivity (Farrell et al., 1995). Although minor isotopic fractionation occurs during diagenesis in regards to carbon (Calvert et al., 1992), nitrogen isotopes may be heavily influenced by bacterial decay, especially as a result of denitrification in anoxic environments (Altabet, 1988; Altabet et al., 1995). 


\subsection{Oceanographic and Geologic Settings}

The Japan Sea is a semi-enclosed marginal sea with an area greater than $1,000,000 \mathrm{~km}^{2}$, an average depth of $\sim 1,350 \mathrm{~m}$, and a maximum depth of $3,700 \mathrm{~m}$ (Figure 2.1). The Japan Sea is connected to adjacent seas by narrow, shallow straits with the main water influx from the East China Sea through the Tsushima Strait ( $\sim 130 \mathrm{~m}$ sill depth, $<90$ $\mathrm{km}$ width) and outflow to the North Pacific through the Tsugaru Strait ( 130 m depth), and the Sea of Okhotsk through the Soya (55 m depth) and Mamiya Straits ( 15 m depth)(Tada et al., 2015). The shallow sill depths of these straits have significantly influenced the paleoceanography of the Japan Sea (Wang, 1999). Presently, the only current that flows into the Japan Sea is the TWC, which began $~ 1.7$ Mya (Itaki, 2016), with additional evidence of warm-water intrusion as early as $3.5 \mathrm{Ma}$ from warm-water mollusks, plankontic foraminifera, and diatom abundances (Kitamura \& Kimoto, 2006; Koizumi, 1992). 


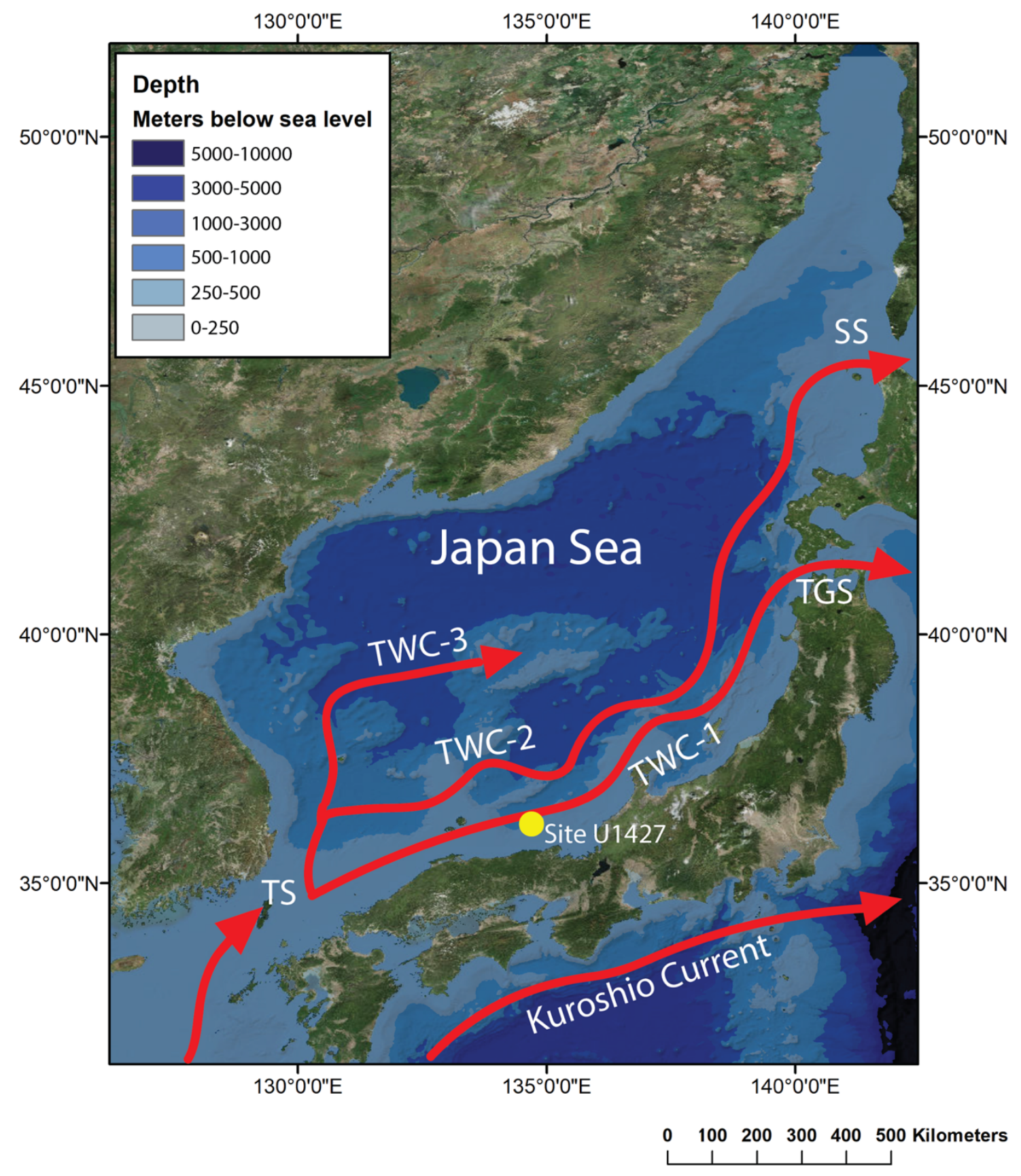

Figure 2.1. Map of the Japan Sea, modern current flux, and Site U1427. TS = Tsushima Strait; TGS = Tsugaru Strait; SS = Soya Strait; MS = Mamiya Strait; TWC-1, TWC-2, TWC-3 are the first, second, and third branch of the Tsushima Warm Current, respectively. The map was created using ArcMap 10.3 (Modified from Gallagher et al., 2018.) 
The TWC, a branch of the Kuroshio Current (Gallagher et al., 2009; 2015), is formed in the East China Sea by mixing of the warm, saline Kuroshio Current and the nutrient-rich, less saline ECSCW before flowing through the Tsushima Strait (Hase et al., 1999; Isobe, 1998). The most significant contribution of terrestrial freshwater to the ECSCW is discharge from the Yangtze (Changjiang) and Yellow (Huang He) Rivers into the Yellow and East China seas, which are sensitive to precipitation fluctuations, especially regarding monsoonal intensity (Isobe et al., 2002). Present TWC dynamics through the Tsushima Strait include a flow volume of 1.1 to $2.6 \mathrm{~Sv}$, which varies seasonally (Isobe, 1998), and a surface velocity between 0.3 to $0.4 \mathrm{~m} \mathrm{~s}^{-1}$ (Takikawa \& Yoon, 2005).

After entering the Tsushima Strait, the TWC branches into three segments (Hase et al., 1999; Watanabe et al., 2006). The first, and largest, branch flows northeasterly along the coast of Honshu Island and exits through the Tsugaru Strait (Figure 2.1). The second branch of the TWC flows northeasterly along a similar path west of the first branch. The third branch flows north along the coast of Korea, eventually moving easterly towards the center of the Japan Sea. Seasonal variation of the flow volume of the TWC differs between the three branches (Kim \& Yoon, 1999), with the first branch having a nearly constant volume and the second and third branches are significantly reduced in volume during the winter (Tada, 1994). In the northern Japan Sea, dense, cold water forms because of the presence of sea ice near Vladivostok, Russia and becomes the Japan Sea Proper Water (JSPW)(. The cold $\left(0.1-0.3^{\circ} \mathrm{C}\right)$, dense, low salinity (34 ppt) water is highly oxygenated $\left(>200 \mu \mathrm{mol} \mathrm{kg}^{-1}\right)$ and currently covers all of the Japan Sea at depths below $300 \mathrm{~m}$ (Oba et al., 1991; Tada et al., 1999). 
In the Japan Sea, there are marked differences between glacial and interglacial periods in regard to both climate and oceanographic conditions (Gallagher et al., 2018). The Japan Sea has commonly been referred to as a "miniature ocean" (Gamo, 2011; Tada et al., 2018) since these shallow, narrow sill depths prohibit inflow or outflow of deep-waters between the Japan Sea and the surrounding seas. The relative isolation of the Japan Sea in comparison to open-ocean environments will lead to an improved understanding of future global climate changes and the resulting oceanographic variations in large marginal seas.

Japan Sea sediments characteristically have readily distinguishable alternations of dark and light-colored layers (Tada, 1999; Watanabe et al., 2007; Tada et al., 2015, 2018). The dark layers are occasionally laminated whereas the light layers are homogeneous to bioturbated. The meter-scale alternations of light and dark sedimentary units record orbital-scale variations in surface and deep-water circulation while centimeter-scale alternations in the light and dark sequences record millennial-scale climatic oscillations (Tada et al., 2015; Tada et al., 1999). Tada (1992) further demonstrated the light/dark sedimentary cycles were synchronous basin-wide and that they can be correlated between sites in the study area (Tada et al., 2018).

The deposition of light and dark-colored layers has been shown to be a result of different circulation modes within the Japan Sea. As sea level fluctuated, it affected the volume and type of oceanic currents entering the Japan Sea, resulting in four modes of circulation during the last 200 ky (Tada et al., 1999)(Figure 2.2). 1) During sea level low stands ( $<40 \mathrm{~m}$ sill depth of the Tsushima Strait), the Japan Sea was nearly isolated from influx of both the TWC and ECSCW because of the shallow strait. Precipitation then 
became the largest influx into the sea, resulting in a lower salinity surface layer with a strong pycnocline that reduced vertical mixing, which led to euxinic environments and deposition of a thick dark layer. 2) The second mode of Japan Sea circulation was during periods of low sea levels (40-70 $\mathrm{m}$ sill depth) and oscillated between water column dynamics depending on the current influx. Increased relative contributions from the TWC increased vertical mixing, which led to winter cooling in the northern Japan Sea and oxic water column conditions, resulting in deposition of a thin light sedimentary layer. A higher relative contribution of the ECSCW decreased surface salinity, decreased vertical mixing and created suboxic environments. The higher nutrient loads of the ECSCW in comparison to the TWC led to slightly higher rates of primary productivity in the surface waters. The combination of suboxic environments and slightly higher productivity resulted in the deposition of a dark layer containing $<3 \%$ TOC. 3) The third mode of circulation occurred during intermediate sea levels (70-110 $\mathrm{m}$ sill depth) and also oscillated between relative contributions of the TWC and ECSCW. Higher contribution from the TWC resulted in a thin, light layer like in the second mode while increased contribution from the nutrient-rich ECSCW led to higher rates of primary productivity, resulting in suboxic to euxinic water columns and a higher TOC (3-5\%) dark layer. 4) The fourth circulation mode of the Japan Sea happened during sea level high stands $(>110 \mathrm{~m}$ sill depth) with a predominant influx of the TWC which led to a thick, light layer. 


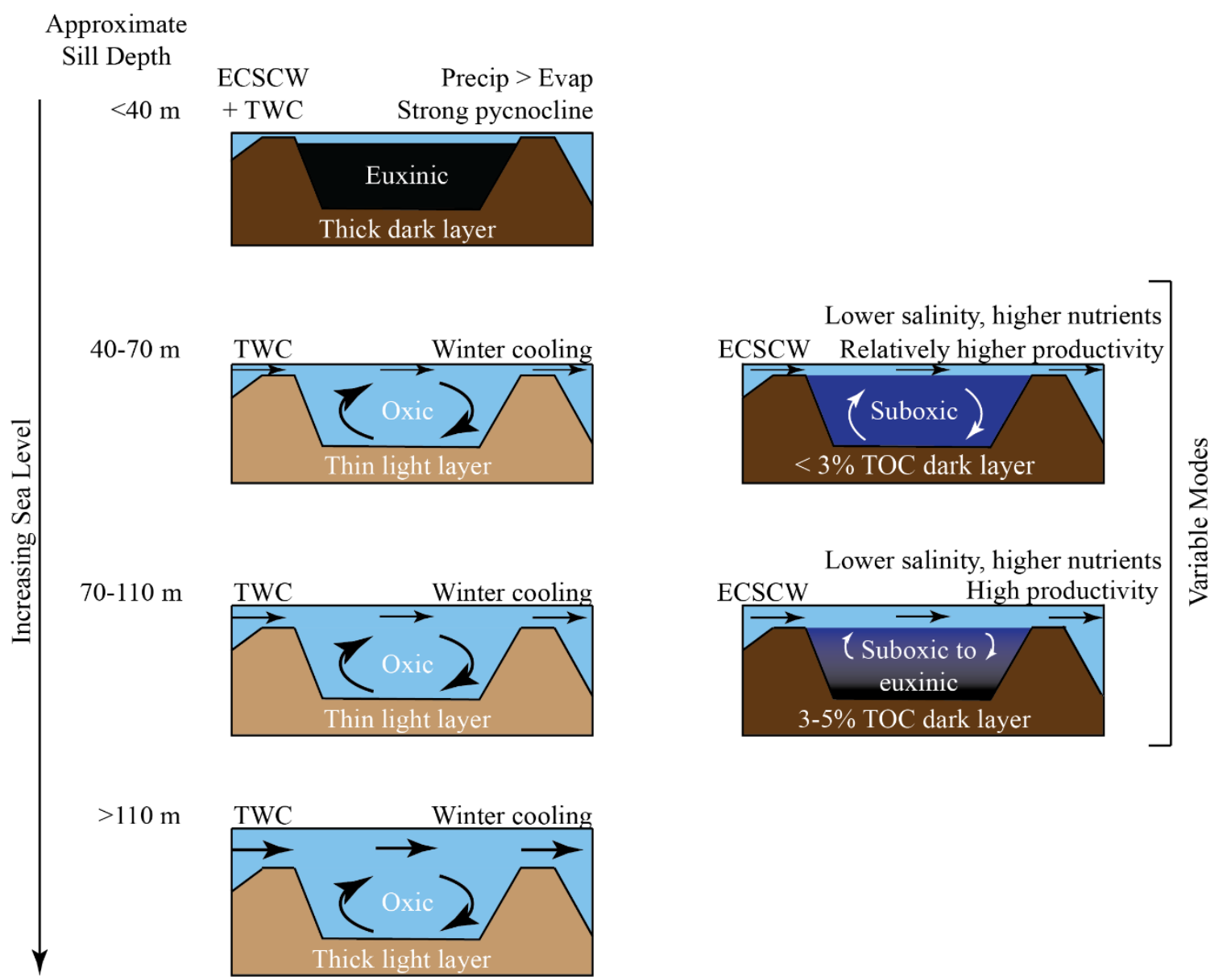

Figure 2.2. Concept diagram of circulation and oxygenation modes within the Japan Sea as a result of increasing sea level and varying ocean current influx. (Modified from Tada et al., 1999.)

Lowering of glacio-eustatic sea level during the last glacial maximum limited influx through the Tsushima Strait, causing suboxic bottom water conditions (Lee et al., 2003) which are associated with thick organic-rich, dark sedimentary layers. The resulting reduction in oceanic currents flowing through the Tsushima Strait resulted in the development of a low salinity surface layer caused by increased relative contribution by precipitation and terrestrial runoff, which in turn increased water column stratification and limited deep-water ventilation (Oba et al., 1991). Light sedimentary layers are associated with oxic conditions during interglacial periods and interstadial periods during 
glacials when there was a significant influx of the TWC through the Tsushima Strait (Tada et al., 1999).

Typically during interglacial periods, such as Marine Isotope Stage (MIS) 5 (80$130 \mathrm{Mya})$, the TWC and ECSCW have varying relative contributions of water entering through the Tsushima Strait (Tada et al., 1999). The Kuroshio Intermediate Water, which is the primary nutrient source in the East China Sea, contributes high concentrations of phosphorous and nitrates $\left(\mathrm{NO}_{3} \sim 25 \mu \mathrm{mol} \mathrm{kg}{ }^{-1} ; \mathrm{PO}_{4} \sim 1.7 \mu \mathrm{mol} \mathrm{kg}{ }^{-1} ; \mathrm{SiO}_{2} \sim 60 \mu \mathrm{mol} \mathrm{kg}{ }^{-1}\right)$ caused by upwelling in the estuary (Chen, 1996; Lee Chen et al., 1999), while the higher salinity, nutrient-poor TWC increases vertical mixing between surface and deep-water masses, creating oxic bottom water conditions (Tada et al., 1999).

However, during glacial periods such as MIS 2 and MIS 6, glacio-eustatic sea level lowering had significant effects on the oceanographic conditions, such as bottom water advection and surface productivity, as a result of the shallow sill depths and near isolation of the Japan Sea from the East China Sea (Oba et al., 1991; Wang, 1999; Gallagher et al., 2018). Increased water column stratification occurred during these glacial periods as a result of less saline water being the predominant influx to the Japan Sea from both precipitation and increased relative contribution of ECSCW (Watanabe et al., 2007). The salinity differences limited vertical mixing of surface and deep-waters, thus creating suboxic bottom water environments with better organic matter preservation (Tada et al., 1999; Usami et al., 2013; Watanabe et al., 2007). 


\subsection{Study Site}

The present study analyzes sediment cores from IODP Expedition 346 collected in the Japan Sea in 2013. The expedition had the overall objective of determining the onset of orbital and millennial-scale variability of the East Asian Monsoon, position and intensity of the Westerly Jet, the paleoceanography of the Japan Sea, and the interrelationships between these variables during the last $5 \mathrm{My}$ (Tada et al., 2015). A total of seven sites in the Japan Sea and two additional sites in the East China Sea were cored to obtain a $\sim 5$ My record of the East Asian Monsoonal history (Tada et al., 2015). The focus of the present study, Site U1427, is located in the south-central part of the Japan Sea on the outer margin of the marginal terrace near Tottori (Figure 2.1). At $35^{\circ} 57.92^{\prime} \mathrm{N}$, $134^{\circ} 26.06^{\prime} \mathrm{E}$, it is the shallowest of all IODP Expedition 346 study sites at $330.3 \mathrm{mbsl}$ (meters below sea level) and is directly under the influence of the first branch of the TWC. Expedition 346 cored nearly $550 \mathrm{~m}$ of continuous sedimentary sequences from Site U1427, which spans the last 1.1 My (Sagawa et al., 2018).

The present study focuses on stable isotope analyses and foraminiferal assemblages of the upper $130 \mathrm{~m}$ and $\sim 350 \mathrm{ky}$ of the site. The calculated age model (Figure 2.3)(Sagawa et al., 2018) suggests a sedimentation rate of $\sim 35 \mathrm{~cm} / \mathrm{ky}$ in this section, providing a high-resolution record of paleoceanographic variability during the Late Pleistocene. The shallow depth of Site U1427 implies that it has likely been located above the calcite compensation depth (CCD)(Tada et al., 2015) with the exception of the sea level low stands during MIS 2, MIS 6, and MIS 10 and has relatively high carbonate preservation (Gallagher et al., 2018). 

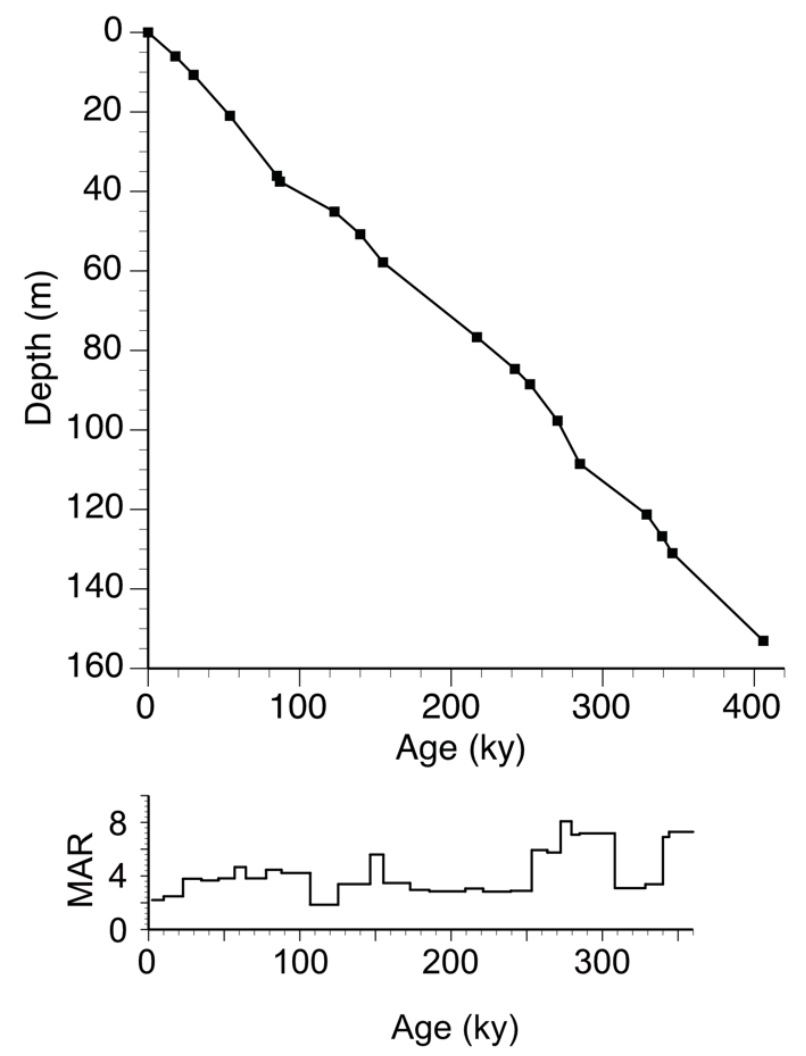

Figure 2.3. Age-depth curve (m/ky)(Sagawa et al., 2018) and the mass accumulation rate (MAR; $\mathrm{g} / \mathrm{cm}^{2} / \mathrm{ky}$ ) of Site U1427.The age model was created by stratigraphic correlation of tephra layers and benthic foraminifera $\delta^{18} \mathrm{O}$ isotope values at Site U1427. MAR was calculated by multiplying the linear sedimentation rate (LSR; $\mathrm{cm} / \mathrm{ky}$ ) by the measured dry bulk density $\left(\mathrm{g} / \mathrm{cm}^{3}\right)$ of the sediment.

The sediments cored at Site U1427 are predominately clayey silt and nannofossilrich clayey silt (Tada et al., 2015; Sagawa et al., 2018; Gallagher et al., 2018). Five agediagnostic tephra layers are present: Aira-Tanzawa (AT), Aso-4, Ata-Torihama (Ata-Th), Aso-1, and Kakuto (Kkt), and one unknown tephra layer, which allows precise dating and basin-wide correlation between IODP 346 sites (Sagawa et al., 2018). Sediment color ranges from an olive gray to grayish green and is typically bioturbated and homogenous (Tada et al., 2015). Nannofossils are abundant throughout the core except for the 
intervals 160-180 m and 224-245 m depth (Sagawa et al., 2018). Foraminiferal are typically well preserved although in low abundance ( $\sim 300$ foraminifera/gram). The assemblages are dominated by planktic foraminifera (Gallagher et al., 2018). Periods of high foraminiferal abundance include MIS 3, MIS 4, MIS 5, MIS 6, MIS 7, and MIS 9 (Gallagher et al., 2018). Sediments recovered from Expedition 346 sites deeper than $800 \mathrm{~m}$ water depth have distinct centimeter- to decimeter-scale light/dark sedimentary alternations (Tada et al., 2015). However, Site U1427 shows only subtle, meter-scale color alternations as a result of its shallow depth, which likely remained located above the oxic-anoxic boundary ( $\sim 500 \mathrm{~m}$ water depth) over the last 1 My (Sagawa et al., 2018).

\subsection{Foraminiferal Assemblages}

The most common planktic foraminifera at Site U1427 are Neogloboquadrina pachyderma (Ehrenberg, 1861), Globigerina bulloides (d'Orbigny, 1826), and Globigerina quinqueloba (Natland, 1938), which are productivity indices (Chapman et al., 1996; Conan \& Brummer, 2000; Domitsu \& Oda, 2005; Prell, 1984; Rohling et al., 1997; Stefanelli et al., 2005). Dominance of Neogloboquadrina pachyderma (rightcoiling) is indicative of cold $\left(0-9^{\circ} \mathrm{C}\right)$, polar front water in the northern Japan Sea (Singh et al., 2015) and presently dominates ( $>50 \%)$ the foraminiferal assemblages in central and northern Japan Sea sediments (Domitsu \& Oda, 2005). However, N. pachyderma is more closely related to the presence of a pycnocline rather than the mixing of surface waters (Usami et al., 2013). Globigerina bulloides is the next most common species in the Japan Sea $(>30 \%)($ Domitsu \& Oda, 2005) and its dominance is indicative of slightly warmer cold water $\left(3-19^{\circ} \mathrm{C}\right)($. The species is found abundantly in modern sediments near the 
Tsushima Strait and has been used as a proxy to determine the input of less saline, nutrient-rich water from the Yangtze River (Domitsu \& Oda, 2005). Unlike $N$. pachyderma, the species thrives in areas of active mixing of subsurface waters (Kuroyanagi et al., 2006; Stefanelli et al., 2005). Globigerina quinqueloba is also a common species in the Japan Sea, dominates near the Tsushima Strait, and is found in high abundance in surface sediments near the mouth of the Yangtze River in the East China Sea (Xu \& Oda, 1999). It is tolerant of low salinities in surface waters (Kuroyanagi \& Kawahata, 2004; Rohling et al., 1997) and is a common species in upwelling conditions (Abrantes et al., 2001).

One of the most common taxa in the benthic foraminiferal assemblages at Site U1427 is Uvigerina peregrina (Cushman, 1923)(also referred to as U. akitaensis (Asano, 1950) by Usami et al., 2013 and Gallagher et al., 2018) and spinose/striate Uvigerina spp. The taxa often prevail in upwelling regions and areas with increased productivity in surface waters (Bubenshchikova et al., 2015) at depths of 45-4500 m (Schonfeld, 2006; Gallagher et al., 2018). Uvigerina peregrina/akitaensis is an infaunal detritus feeder (Bubenshchikova et al., 2008, 2015; Fontanier et al., 2014) whose abundance is controlled by variations within the TOC flux rates towards the seafloor (Usami et al., 2013). Uvigerina spp. is a common species in phosphate and nitrate-rich water masses (Usami et al., 2013; Gallagher et al., 2018; Jian et al., 2001), indicating increased nutrient loading and increased surface primary productivity.

Globigerinoides ruber, Pulleniatina obliquiloculata (Parker \& Jones, 1862), Globorotalia tumida/menardii (Brady, 1877), and Neogloboquadrina incompta (Cifelli, 1961) are planktic foraminifera directly associated with the influx of the TWC (Gallagher 
et al., 2015, 2018; Domitsu \& Oda, 2005) and are grouped together as "TWC planktics." Globigerinoides ruber is likely the most important indicator of the TWC with abundances greater than $30 \%$ in modern sediments (Domitsu \& Oda, 2005), and occurs abundantly in warmer waters $\left(21-29^{\circ} \mathrm{C}\right)$ associated with stratified waters outside of upwelling regions (Be, 1977). It is also common in the East China Sea in surface sediments near the Yangtze River, in the Kuroshio Current, and the Tsushima Strait (Domitsu \& Oda, 2005; Oda et al., 1992; Gallagher et al., 2015). Neogloboquadrina incompta prefers colder waters $\left(10-18^{\circ} \mathrm{C}\right)$ than G. bulloides (Salgueiro et al., 2008; Thunell \& Sautter, 1992), but warmer waters than $N$. pachyderma (Usami et al., 2013). It is associated with upwelling conditions (Reynolds \& Thunell, 1985) and high chlorophyll-a concentrations (Abrantes, 2001). Currently, $N$. incompta is found in middle to downstream areas of the TWC, where mixing between the TWC and colder, northern water occurs (Domitsu \& Oda, 2005).

\subsection{Methods}

All sedimentary organic matter samples $(n=135)$ were analyzed for Florida International University’s Southeastern Environmental Research Center's Stable Isotope Laboratory (SERC-SIL). All samples were dried and ground until fine before being homogenized in a Spex 8000M mixer/mill for 5 minutes. Samples prepared for organic carbon isotope analysis were decarbonated by acidifying $\sim 0.1 \mathrm{~g}$ of ground sediment sample in $10 \% \mathrm{HCl}$ bath for 24 hours three times followed by decantation in deionized water (DI) three times to rinse away acid residue. Five mg of decarbonated sediment for organic carbon analysis and $10 \mathrm{mg}$ of non-decarbonated sediment for bulk nitrogen 
analysis were compacted in $5 \times 9 \mathrm{~mm}$ tin capsules and analyzed in a NA 1500 elemental analyzer (EA) coupled to a Thermo Delta $\mathrm{C}$ isotope ratio mass spectrometer (IRMS) for $\%$ TOC and $\delta^{13} \mathrm{C}_{\mathrm{TOC}}$, and $\% \mathrm{~N}$ and $\delta^{15} \mathrm{~N}$, respectively.

All isotope data is expressed as delta notation $(\delta \%)$, using the equation

$$
\delta \mathrm{R}=\left[\left(\mathrm{R}_{\text {sample }}-\mathrm{R}_{\text {standard }}\right) / \mathrm{R}_{\text {standard }}\right] * 1000
$$

where $R_{\text {sample }}$ is the ratio of the heavy to light isotope in the sample and $R_{\text {standard }}$ is the ratio of the heavy to light isotope in the standard (McKinney et al., 1950; Hayes, 1982; Coplen, 2011). The $\delta^{13} \mathrm{C}$ and $\delta^{15} \mathrm{~N}$ data are reported in parts per mil (\%o) vs. Vienna Pee Dee Belmnite (VPDB) and AIR, respectively. Precision $(1 \sigma)$ was better than $\pm 0.14 \%$ for organic carbon and $\pm 0.21 \%$ for nitrogen using analysis of internal standards over a range of isotopic values (Appendix 1).

The procedure for processing inorganic carbon samples followed a similar method to shipboard analyses (Tada et al., 2015). Fifteen mg of ground, homogenized sample was acidified in $10 \mathrm{~mL}$ of $10 \% \mathrm{HClO}_{4}$ in a UIC CM140 Coulometer for inorganic carbon analysis. Calcium carbonate concentration $\left(\% \mathrm{CaCO}_{3}\right)$ was calculated from the inorganic carbon concentration by multiplying by a factor of 8.33 under the assumption that all

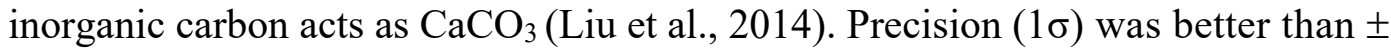
$0.19 \% \mathrm{CaCO}_{3}$ on the basis of analysis of Fisher Chemical's pure calcium carbonate standard $\left(\mathrm{CaCO}_{3}=100.09\right)$ and Nacalai Tesque's pure sodium carbonate standard $\left(\mathrm{Na}_{2} \mathrm{CO}_{3}=105.99\right)$. Eighty-seven samples were analyzed in duplicate with precision better than $\pm 0.84 \% \mathrm{CaCO}_{3}$.

One hundred and twenty-three samples were processed for foraminifera by standard microfossil techniques for paleoenvironmental analyses (see Gallagher et al., 
2018 for further details)(with emphasis on sea surface conditions and paleoproductivity proxies) at the University of Melbourne ${ }^{3}$. The samples were split using a micro-splitter into several fractions. Quantitative benthic and planktic assemblage data were compiled from the $>150 \mu \mathrm{m}$ fraction since these species are significantly larger than the standard $>63 \mu \mathrm{m}$ fraction. The foraminiferal data are expressed as a percentage of the total fauna (e.g. \%plankton) or as a percentage of the calcareous benthic or planktic assemblages. Foraminiferal concentrations are expressed as numbers of foraminifera per gram of dry sediment (see Gallagher et al., 2018 for further details). For the present work, the percentage of Neogloboquadrina pachyderma, Globigerina bulloides, and Globigerina quinqueloba in the planktic assemblage, and relative abundance of Uvigerina peregrina (akitaensis), and Uvigerina spp. (spinose and striate) are plotted to show periods of increased primary productivity and upwelling variability. The total number of foraminiferal assemblages for the group "TWC planktics" (Globigerinoides ruber, Pulleniatina obliquiloculata, Globorotalia tumida/menardii, and Neogloboquadrina incompta) reflect the relative influence of the TWC during sea level maxima (Gallagher et al., 2018; Domitsu \& Oda, 2005; Usami et al., 2013).

Continuous sedimentary sequences were constructed from the sediment collected during IODP Expedition 346 using the splicing technique correlating physical properties, lightness $\left(\mathrm{L}^{*}\right)$, and color $\left(\mathrm{b}^{*}\right)$ between multiple holes at each sampling site (Irino et al.,

\footnotetext{
${ }^{3}$ Data was collected, analyzed, and published by Gallagher (2018).
} 
$2018)^{4}$. Sample ages were determined via the age models (Figure 2.3) of Sagawa (2018) through correlation of tephra layers and $\delta^{18} \mathrm{O}$ values of benthic calcareous microfossils. Water depth through the sill of the Tsushima Strait was calculated from global sea level estimates (Spratt \& Lisiecki, 2016) and divided into four circulation modes according to Tada (1999). All L* and $\mathrm{b}^{*}$ data were calculated using color scanning imaging at a $5 \mathrm{~mm}$ resolution (Irino et al., 2018).

Principal Component Analysis (PCA) was used to determine the correlation of the elemental and isotopic geochemical data $\left(\mathrm{CaCO}_{3}, \mathrm{TOC}, \mathrm{TN}, \delta^{13} \mathrm{C}\right.$, and $\left.\delta^{15} \mathrm{~N}\right)$ in relation to glacial/interglacial MIS stages (MIS 1 to MIS 10) and variations in sill depth (Tada et al., 1999) of the Tsushima Strait and was calculated using the JMP statistical software package. Principal component analysis is a multivariate statistical analysis that determines the underlying variability between discrete independent variables such that the first principal component (PC1) explains the largest possible variance, followed by PC2, PC3, etc. (Pearson, 1901; Wold et al., 1987; Joliffe, 2002;). All data $\left(\mathrm{CaCO}_{3}\right.$, TOC, $\mathrm{TN}, \delta^{13} \mathrm{C}$, and $\delta^{15} \mathrm{~N}$ ) was mean centered and standardized by variance before PCA analysis. The Pearson correlation coefficient (Adler \& Parmryd, 2010) was also calculated in JMP to determine the correlation between independent variables.

\footnotetext{
${ }^{4}$ Data was collected onboard the Joides Resolution by Expedition 346 Scientists. See Tada (2015) for more details.
} 


\subsection{Results}

The calcium carbonate concentration $\left(\% \mathrm{CaCO}_{3}\right)$ varied from $0.0 \%$ to $23.0 \%$, TOC $0.2 \%$ to $5.0 \%, \delta^{13} \mathrm{C}-25.3 \%$ o to $-19.6 \%$, $\% \mathrm{~N} 0.0 \%$ to $0.2 \%$, and $\delta^{15} \mathrm{~N} 3.8 \%$ to 13.1\%o (Figure 2.4; Appendix 2; Black et al., 2018). The variation in these data correlate with sediment $\mathrm{L}^{*}$ and $\mathrm{b}^{*}$ color values reflecting distinct differences between glacial and interglacial periods. The calculated Pearson correlation coefficient between $\mathrm{L}^{*}$ and $\%$ TOC is $\mathrm{r}=-0.48, \mathrm{p}<0.0001$ and between $\mathrm{b}^{*}$ and $\% \mathrm{CaCO}_{3}$ is $\mathrm{r}=0.51, \mathrm{p}<0.0001$. 


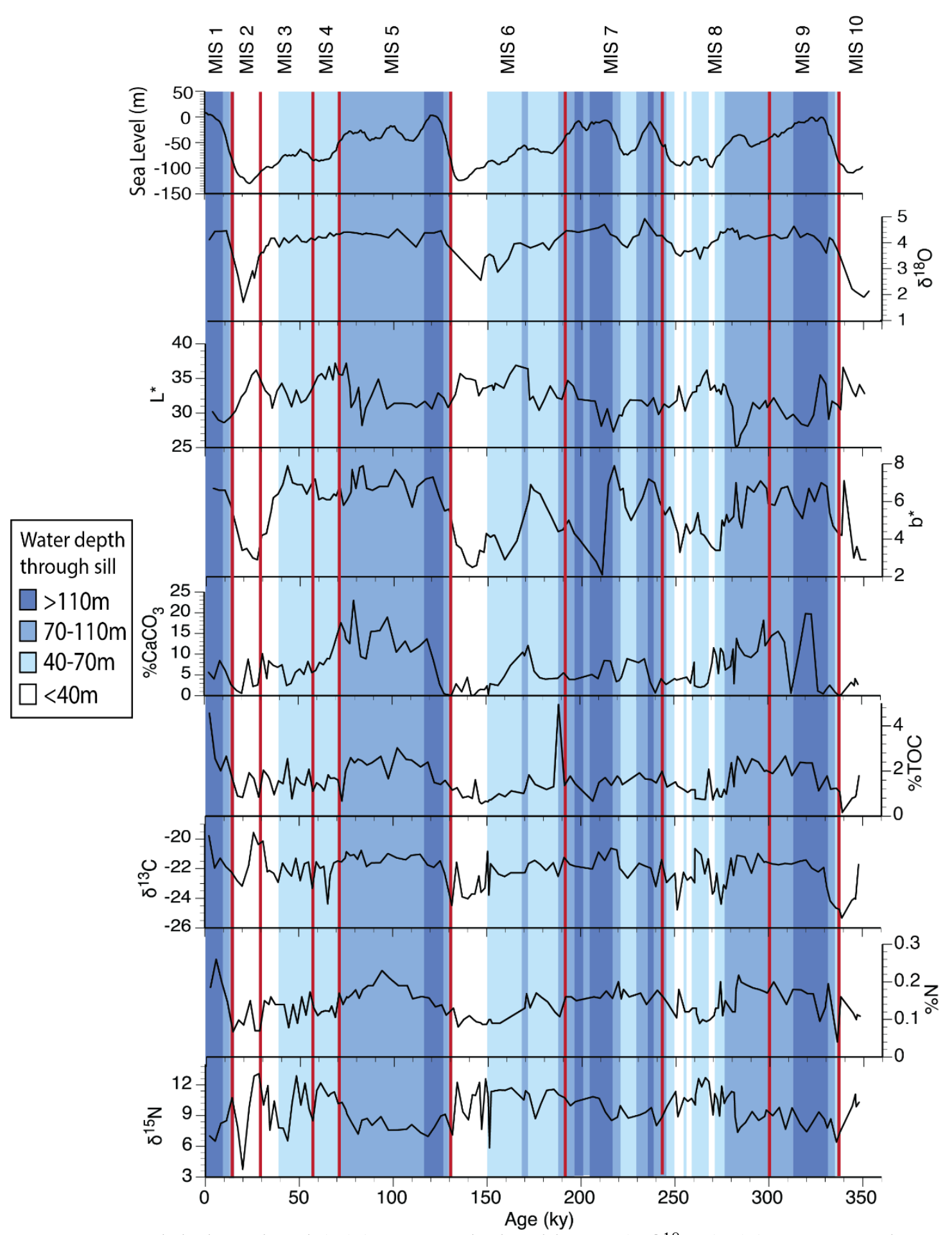

Figure 2.4. Global sea level $(\mathrm{m})$ (Spratt and Lisecki, 2016), $\delta^{18} \mathrm{O}(\%)$ (Sagawa et al., 2018), L* (Irino et al., 2018), b* (Irino et al., 2018), calcium carbonate $\left(\% \mathrm{CaCO}_{3}\right)$, total organic carbon $(\% \mathrm{TOC}), \delta^{13} \mathrm{C}$, total nitrogen $(\% \mathrm{~N})$, and $\delta^{15} \mathrm{~N}$ content of sediment samples from Site U1427. Sill depth through the Tsushima Strait was divided into four modes following Tada et al. (1999). 
Tada et al. (1999) determined that Japan Sea sediments that are typically lighter in color (higher L* values) and have relatively lower calcium carbonate concentrations $\left(\sim 15 \% \mathrm{CaCO}_{3}\right)$ typify glacial periods. Glacial maxima, however, are the exception when dark sediments were deposited likely as a result of increased stratification and development of euxinic conditions in the water column. The lighter sediments in MIS 2, MIS 6, MIS 8, and MIS 10 have relatively lower $\% \mathrm{CaCO}_{3}, \% \mathrm{TOC}$, and $\% \mathrm{~N}$, and depleted $\delta^{13} \mathrm{C}$ and enriched $\delta^{15} \mathrm{~N}$ values (-26\%o to $-24 \%$ and $2 \%$ to $7 \%$, respectively) when compared to the darker units (-20\%o to $-23 \%$ and $6 \%$ to $8 \%$, respectively) deposited during MIS 1 (0-11 kya), MIS 3 (24-60 kya), MIS 5 (70-130 kya), MIS 7 (190244 kya), and MIS 9 (301-334 kya)(Black et al., 2018).

The PCA was performed using a subset of 5 variables $\left(\% \mathrm{CaCO}_{3}, \% \mathrm{TOC}, \delta^{13} \mathrm{C}\right.$, $\% \mathrm{~N}$, and $\left.\delta^{15} \mathrm{~N}\right)$ on all samples $(\mathrm{n}=135)$ analyzed. The first two principal components (PC) in MIS comparisons explain $88.8 \%$ of the total data set variance, so the remaining PCs can be excluded from the analysis. In the variable space, (Figure 2.5), PC1 explains $70.2 \%$ of the variance and shows a significant positive correlation with $\% \mathrm{CaCO}_{3}, \% \mathrm{TOC}$, $\delta^{13} \mathrm{C}$, and $\% \mathrm{~N}$ and a significant negative correlation with $\delta^{15} \mathrm{~N}$. The second principal component, PC2, explains $18.6 \%$ of the variance and shows a significant positive correlation with $\% \mathrm{CaCO}_{3}$, moderate positive correlation with $\% \mathrm{~N}$ and $\delta^{15} \mathrm{~N}$, and a slight to moderate negative correlation with $\% \mathrm{TOC}$ and $\delta^{13} \mathrm{C}$. The factor loadings obtained from the PCAs are shown in Tables 2.1 and 2.2 for MIS age and sill depth, respectively. 
a)
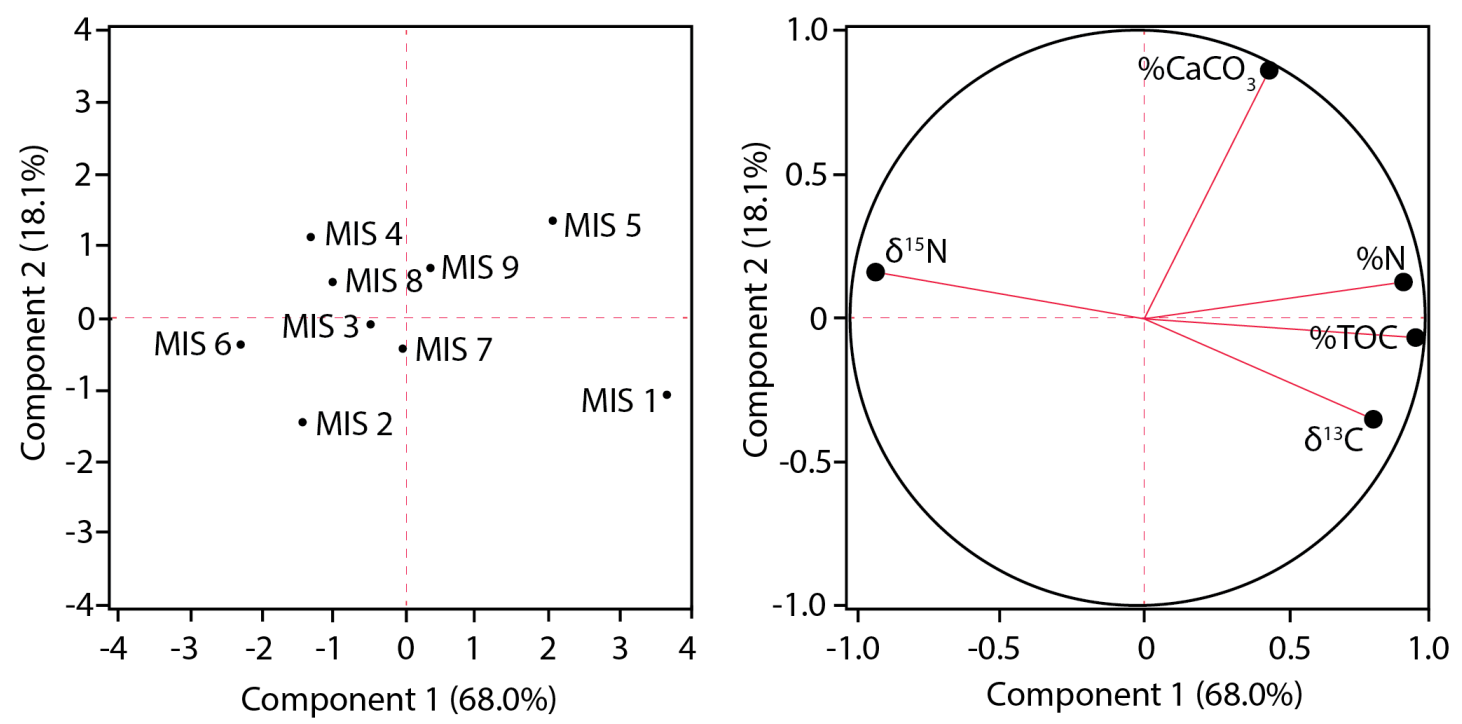

b)
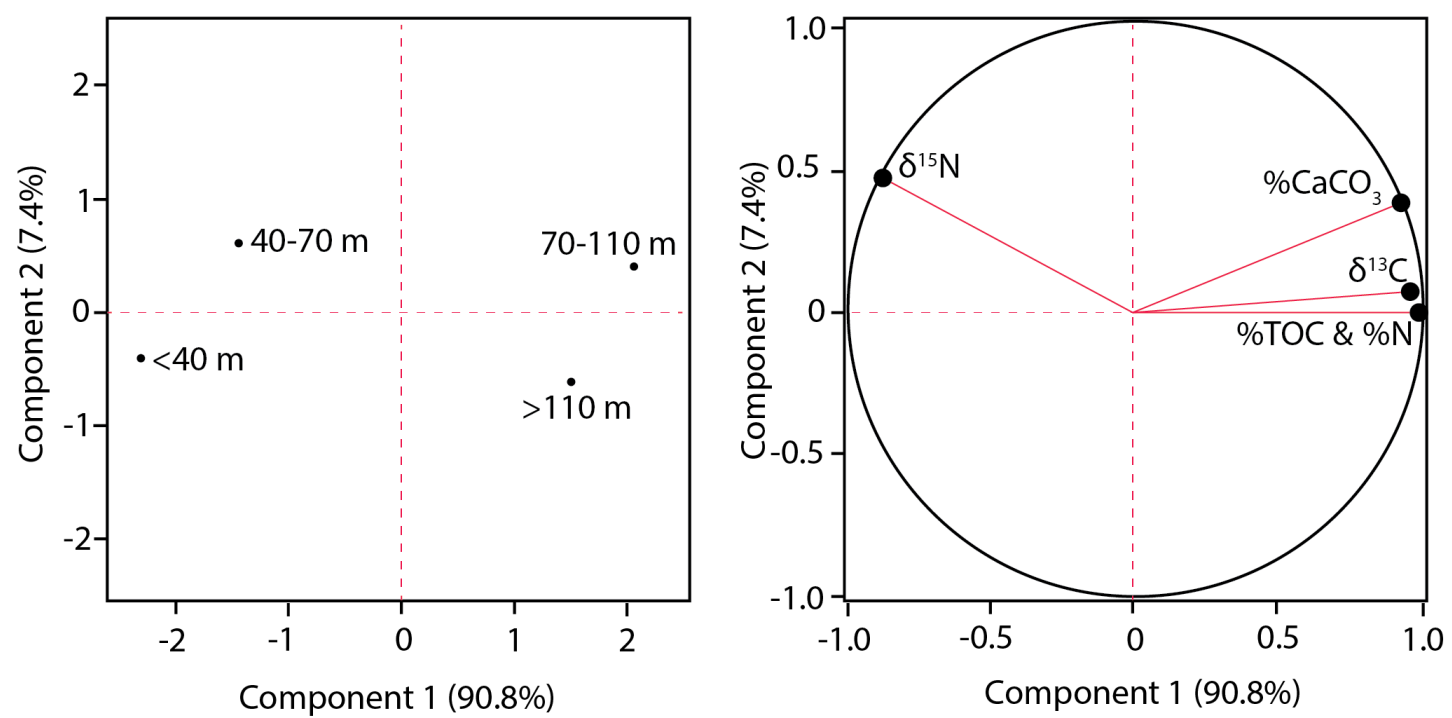

Figure 2.5 Principal Component Analysis (PCA) of $\% \mathrm{CaCO}_{3}, \% \mathrm{TOC}, \% \mathrm{~N}, \delta^{13} \mathrm{C}$, and $\delta^{15} \mathrm{~N}$ analyzed by (a) MIS 1 through MIS 9 and (b) varying sill depths of the Tsushima Strait according to the four circulation modes of the Japan Sea determined by Tada (1999). 
Table 2.1. The contribution of geochemical proxy variables in PCA calculation for MIS 1 through MIS 9 (Figure 2.5a).

\section{Principal 1 Principal 2}

\begin{tabular}{lll}
\hline$\% \mathrm{CaCO}_{3}$ & 0.45 & 0.87 \\
$\% \mathrm{TOC}$ & 0.97 & -0.07 \\
$\delta^{13} \mathrm{C}$ & 0.82 & -0.35 \\
$\% \mathrm{~N}$ & 0.92 & 0.12 \\
$\delta^{15} \mathrm{~N}$ & -0.92 & 0.16 \\
\hline
\end{tabular}

Sill depth of the Tsushima Strait was also analyzed over time for the same subset of 5 variables $\left(\% \mathrm{CaCO}_{3}, \% \mathrm{TOC}, \delta^{13} \mathrm{C}, \% \mathrm{~N}\right.$, and $\left.\delta^{15} \mathrm{~N}\right)$ analyzed for depths $<40 \mathrm{~m}, 40$ 70m, 70-110m, and $>110 \mathrm{~m}$ using the four circulation modes of Tada (1999). The first two principal components in the sill depth comparison explain $98.2 \%$ of the variance. In the variable space (Figure 2.5), PC1 explains $90.8 \%$ of all variance between proxies and shows a significant positive correlation between $\% \mathrm{CaCO}_{3}, \% \mathrm{TOC}, \delta^{13} \mathrm{C}$, and $\% \mathrm{~N}$ and a significant negative correlation with $\delta^{15} \mathrm{~N}$. PC2 indicates only $7.4 \%$ of the variance, with slight to moderate positive correlation between all variables. 
Table 2.2. The contribution of geochemical proxy variables in PCA calculation for varying sill depths of the Tsushima Strait according to the four circulation modes of the Japan Sea determined by Tada (1999)(Figure 2.5b).

\section{Principal 1 Principal 2}

\begin{tabular}{lll}
\hline$\% \mathrm{CaCO}_{3}$ & 0.92 & 0.37 \\
$\% \mathrm{TOC}$ & 1.0 & -0.01 \\
$\delta^{13} \mathrm{C}$ & 0.96 & 0.08 \\
$\% \mathrm{~N}$ & 0.99 & 0.0 \\
$\delta^{15} \mathrm{~N}$ & -0.88 & 0.47 \\
\hline
\end{tabular}

Planktic and benthic foraminiferal assemblage variability also correlates to variations in the previously discussed geochemical and isotopic proxy data, especially $G$. bulloides, G. quinqueloba, U. peregrina (akitaensis), and Uvigerina spp (Usami et al., 2013; Gallagher et al., 2018). The abundances of these foraminiferal taxa also increase during interglacial periods and are less abundant during glacial periods. Less abundant species that are specific to the influx of the TWC into the Japan Sea, such as G. ruber, $P$. obliquiloculata, G. tumida/menardii, and N. incompta (Domitsu \& Oda, 2006; Gallagher et al., 2015; Kitamura et al., 2001) are only present intermittently in sediment layers deposited when the sill depth during interglacial periods was at least $70 \mathrm{~m}$ (Figure 2.6). 


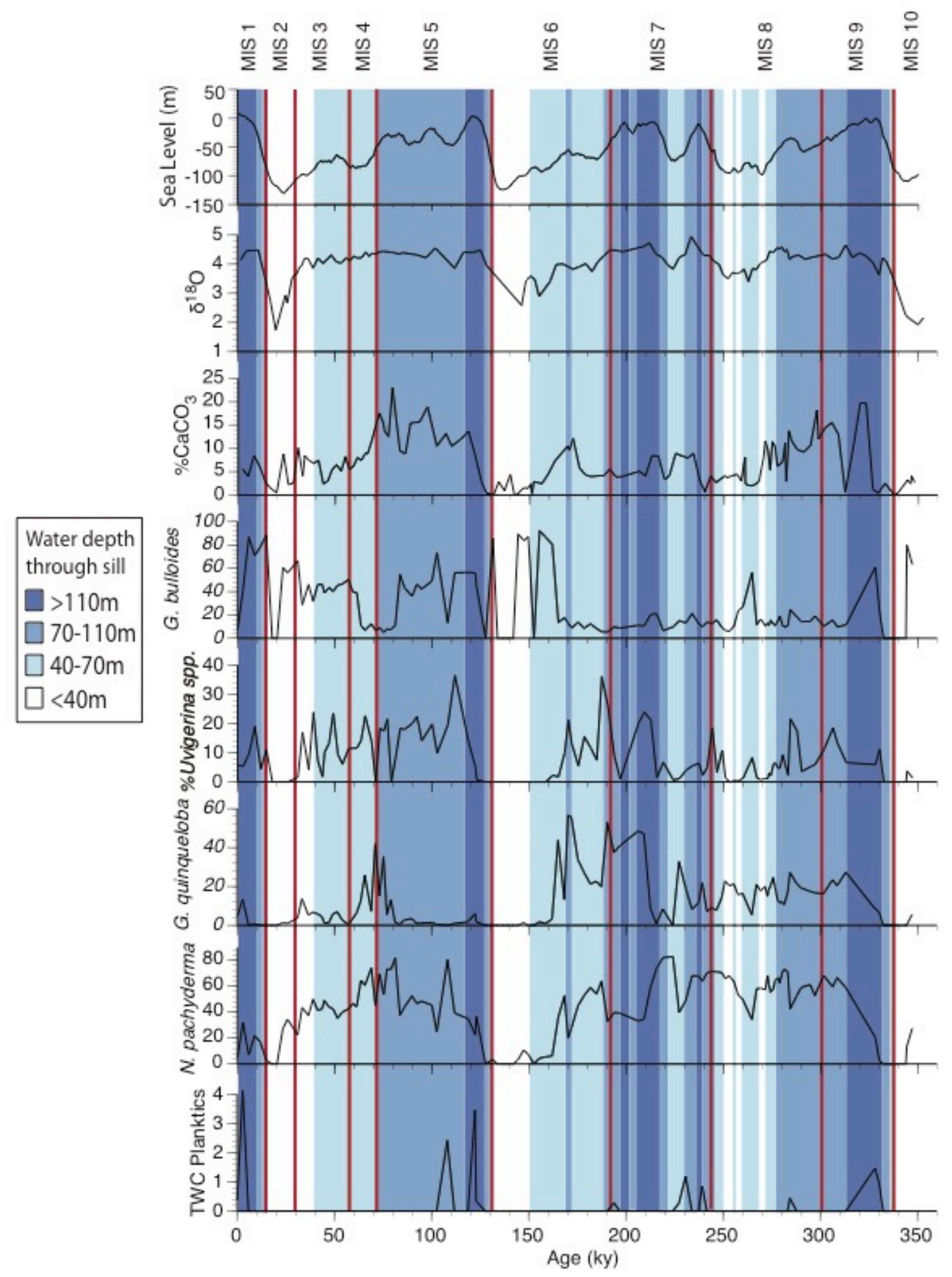

Figure 2.6. Global sea level (m)(Spratt and Lisecki, 2016), $\delta^{18} \mathrm{O}(\%)$ (Sagawa et al., 2018), $\% \mathrm{CaCO}_{3}$, and abundances of $G$. bulloides, Uvigerina spp., G. quinqueloba, $N$. pachyderma and TWC planktics (Gallagher et al., 2018). Sill depth through the Tsushima Strait was divided into four modes following Tada et al. (1999). 


\subsection{Discussion}

Latest Pleistocene to Holocene paleoproductivity variations in the Japan Sea have previously been interpreted using $\% \mathrm{TOC}, \% \mathrm{TN}, \delta^{13} \mathrm{C}$, and $\delta^{15} \mathrm{~N}$ data to investigate sea level controls of the sedimentary record (Khim et al., 2008; Minoura et al., 1997). These authors found that surface productivity controlled the $\delta^{13} \mathrm{C}$ and $\delta^{15} \mathrm{~N}$ contents of the sediment and that these variations were a result of sea level fluctuations and the resulting influx of water into the Japan Sea. Similar to Site U1427, other cores in the Japan Sea show slightly lighter (higher L* values) sediments in glacial periods compared to interglacial sediments except for sea level low stands during MIS 2 and MIS 6 (Oba et al., 1991; Tada et al., 1999). Measured L* values at Site U1427 moderately correlate with TOC content of the sediments $(\mathrm{r}=-0.48, \mathrm{p}<0.001)$, with darker sediments (lower $\mathrm{L}^{*}$ values) yielding higher TOC concentrations than lighter (higher L* values) sediments, indicating that TOC content causes the darker color of the interglacial sediments. The $b^{*}$ values measured indicate bluer sediments (lower $b^{*}$ values) during glacial periods with yellower (higher $b^{*}$ values) during interglacial periods. These $b^{*}$ values moderately correlate to $\% \mathrm{CaCO}_{3}(\mathrm{r}=0.51, \mathrm{p}<0.001)$, suggesting that $\mathrm{b}^{*}$ may serve as a proxy for carbonate concentration in the sediment at Site U1427.

In hemipelagic sediments, $\% \mathrm{TOC}, \% \mathrm{~N}, \delta^{13} \mathrm{C}$, and $\delta^{15} \mathrm{~N}$ content is generally related to the amount of primary productivity in surface waters (Fry \& Sherr, 1984; Peterson \& Howarth, 1987; Peterson \& Fry, 1987; Stein, 1991). As primary productivity increases, increased concentrations of $\%$ TOC and $\% \mathrm{~N}$, as well as isotopic enrichment of

$\delta^{13} \mathrm{C}$ and $\delta^{15} \mathrm{~N}$, are typically expected. The concentration of TOC and $\mathrm{N}$ stored in sediment typically increases during periods of increased primary productivity because of 
the supply of limiting nutrients. Photosynthetic microorganisms also preferentially incorporate the lighter stable isotope, i.e., ${ }^{12} \mathrm{C}$ and ${ }^{14} \mathrm{~N}$, into their diets since they require slightly less energy to metabolize compared to the heavier stable isotopes, i.e., ${ }^{13} \mathrm{C}$ and ${ }^{15} \mathrm{~N}$ (Fry \& Sherr, 1984). As competition for nutrients increases in surface waters, lighter isotopes become depleted and organisms incorporate higher concentrations of the heavier isotopes, leading to isotopic enrichment (Peterson \& Fry, 1987). Site U1427, however, is located in close proximity to the Japanese coast, so it is likely that changes in the organic matter sources areas (i.e., marine vs. terrestrial) could also influence the carbon and nitrogen stable isotope values (Meyers 1994; Schubert \& Calvert, 2001). Marine isotopic values for carbon and nitrogen stable isotopes average $\sim-20 \%$ and $9 \%$, respectively, while terrestrial values average $-27 \%$ and $<1 \%$, respectively (Meyers, 1997; O'Leary, 1981; Peterson \& Howarth, 1987). Site U1427 generally shows a predominantly marine source of organic matter throughout the record with average $\mathrm{C} / \mathrm{N}, \delta^{13} \mathrm{C}$, and $\delta^{15} \mathrm{~N}$ values of $11.5,-22.2 \%$ and $9.7 \%$, respectively. Terrestrial $\mathrm{C} / \mathrm{N}$ values are only present in a total of six samples studied, while the most depleted $\delta^{13} \mathrm{C}$ and $\delta^{15} \mathrm{~N}$ values in the record are $1.7 \%$ and $3.8 \%$, respectively, more enriched than terrestrial isotopic signatures, indicating little terrestrial influence at Site U1427.

Previous studies share relatively similar elemental and isotopic values with the exception of $\delta^{15} \mathrm{~N}$ values, which are 4-5\% more enriched at Site U1427, which could be a result of water depth. Site U1427 is a very shallow site (330 mbsl) in comparison to previous Yamato Basin studies ( $900-3400$ mbsl)(Khim et al., 2008; Minoura et al., 1997), which would limit the amount of degradation in the water column as organic matter settles towards the sea floor, potentially leading to less diagenetically altered 
organic matter preserved in the surface sediments in oxic conditions than in deeper sites. The $\delta^{15} \mathrm{~N}$ values at Site U1427 are only slightly more enriched (4-5\%) than deeper sites during the sea level low stands of MIS 2 and MIS 6, indicating potential bacterial denitrification conditions in the shallower sites. The most depleted $\delta^{13} \mathrm{C}$ and $\delta^{15} \mathrm{~N}$ values in the Japan Sea are from laminated sedimentary layers deposited during glacial periods (Khim et al., 2008; Minoura et al., 1997), which are absent from Site U1427, further indicating that water depth and bottom water oxygenation impart a significant control on the isotopic values of preserved organic matter.

According to PCA analysis, clear differentiation between glacial and interglacial MIS stages are shown between two principal components (Figure 2.5), which comprise $89 \%$ of all variance between the data. In Component 1 , which is most significantly controlled by $\% \mathrm{TOC}, \% \mathrm{~N}$, and $\delta^{15} \mathrm{~N}$, all interglacial periods show a positive correlation while in all glacial stages share a negative correlation. The concentration of \% TOC and $\% \mathrm{~N}$ in sediments is likely related to their role in biochemical cycling, nutrient loading, and the resulting primary productivity in the surface waters. However, in the Japan Sea there is a higher relative contribution of inorganic $\mathrm{N}(<60 \%)$ to total $\mathrm{N}$ stored in the sediments, because of sorption of $\mathrm{NH}_{4}{ }^{+}$to clay particles (Tesdal et al., 2013), and that process complicates the $\mathrm{N}$ analyses. The negative correlation between $\delta^{15} \mathrm{~N}$ and all other geochemical data during glacial periods implies suboxic bottom waters and possible denitrification conditions (Altabet, 1988), especially since MIS 2 and MIS 6 had the most enriched $\delta^{15} \mathrm{~N}$ values and the lowest sea levels in the time interval analyzed.

In the dark sedimentary layers deposited during interglacial periods, an increase in $\% \mathrm{CaCO}_{3}, \% \mathrm{TOC}$, and $\% \mathrm{~N}$ and relative enrichment of $\delta^{13} \mathrm{C}$ suggests increased primary 
productivity in surface waters (Black et al., 2018). The volume of water flowing through the Tsushima Strait has a direct impact on these proxy values where sill depths greater than $70 \mathrm{~m}$ show the most significant increases in paleoproductivity, shown both in the geochemical proxy data and PCA analysis. As more water flows through the Tsushima Strait, it brings with it warmer, more nutrient-rich water, which facilitates vertical mixing and oxygenation of deeper waters (Gamo, 2011), further increasing primary productivity at the surface.

During the transition to glacial periods, however, when the sill depth drops below $\sim 70 \mathrm{~m}, \% \mathrm{CaCO}_{3}, \% \mathrm{TOC}$, and $\% \mathrm{~N}$ values decrease with a relative depletion of $\delta^{13} \mathrm{C}$ and enrichment of $\delta^{15} \mathrm{~N}$. With limited TWC influx, precipitation becomes a more significant contributor to the water entering the Japan Sea as a result of surface runoff, likely causing a freshwater lens to develop at the surface. The fresh surface water increases stratification in the water column, which limits vertical mixing and leads to potentially hypoxic bottom waters (Oba et al., 1991; Tada et al., 1999; Wang, 1999).

There are differences in the correlation of sill depth and the geochemical proxies such that the more extreme sill depths, i.e., $<40 \mathrm{~m}$ and $>110 \mathrm{~m}$ are more similar in comparison to intermediate sill depths, $40-110 \mathrm{~m}$ according to PCA 2 (Figure 2.5). The similarity of intermediate sill depths may indicate that Tada's (1999) circulation modes 2 $\& 3$ are not statistically different, corroborating recent results indicating the presence of only three circulation modes (Saavedra-Pellitero, in press). Oxic conditions associated with a higher influx of the TWC likely resulted in higher $\% \mathrm{CaCO}_{3}$ concentrations and lower $\delta^{15} \mathrm{~N}$ values while suboxic conditions resulted in lower $\% \mathrm{CaCO}_{3}$ through possible dissolution and increased denitrification suggested by more enriched $\delta^{15} \mathrm{~N}$ values. 
There are also marked differences in foraminiferal abundance between glacial and interglacial periods that are likely to have been related to by the volume of water moving through the sill of the Tsushima Strait (Figure 2.5; Gallagher et al., 2018). With minor exceptions, such as MIS 6 and MIS 8, planktic foraminiferal concentration is higher during interglacial periods (1000-3000 foram/g) and significantly lower during glacial periods $(<500 \mathrm{foram} / \mathrm{g})($ Gallagher et al., 2018). Increases in the abundance of planktic foraminifera likely reflect increased surface primary productivity while increases in benthic species indicate increased oxygenation at the base of the water column and/or sediment interface and differential dissolution. The periodic influx of TWC planktic species indicate periods in which significant inflow of the TWC occurred through the Tsushima Strait. Tsushima Warm Current indicating coccolithophorids, (i.e., Emiliania huxleyi, Gephyrocapsa oceanica, Calcidiscus leptoporus, and Helicospharea carteri) also show increased abundances during interglacial periods at Site U1427 when increased abundances of TWC planktic species occurred (Saavedra-Pellitero, in press), corroborating increased TWC influx.

\subsection{Conclusions}

The Japan Sea is an isolated sea connected to the open-ocean via straits such as the Tsushima and Tsugaru Straits with depths less than $130 \mathrm{~m}$. Oceanic conditions such as salinity and primary productivity are therefore actively controlled by glacio-eustacy. The present work integrates geochemical $\left(\% \mathrm{CaCO}_{3}, \% \mathrm{TOC}, \% \mathrm{~N}, \delta^{13} \mathrm{C}\right.$, and $\left.\delta^{15} \mathrm{~N}\right)$ analyses with benthic and planktic foraminiferal data from Site U1427 cored during IODP Expedition 346 (Tada et al., 2015) to document the relative influence of variable 
sill depths in the Tsushima Strait on primary productivity over the last 350,000 years. The shallow, narrow strait restricted the inflow of the Tsushima Warm Current and East China Sea Coastal Waters to the Japan Sea during glacial periods. When sill depth was < $70 \mathrm{~m}$ there was limited influx of the Tsushima Warm Current and/or the East China Sea Coastal Water entering the Japan Sea, causing precipitation to become a more significant contributor to the water body, leading to increased stratification and reduced oxygen concentration limiting surface primary productivity. Enriched $\delta^{15} \mathrm{~N}$ values during glacial periods indicate increased denitrification conditions, suggesting hypoxic water columns and oligotrophic waters.

When the sill depth of the Tsushima Strait was greater than $70 \mathrm{~m}$, however, paleoproductivity rapidly increased during interglacial periods, leading to higher values of $\% \mathrm{CaCO}_{3}, \% \mathrm{TOC}$, and $\% \mathrm{~N}$ and $\delta^{13} \mathrm{C}$ enrichment associated with higher planktic and benthic foraminiferal abundance. Primary productivity increase in surface waters was caused by the warmth and higher salinity of the TWC and high nutrient load of the ECSCW and enhanced vertical mixing in the water column. The appearance of TWC planktic species during interglacial periods indicates TWC influx to the Japan Sea through the Tsushima Strait when the sill depth was greater than $70 \mathrm{~m}$.

\subsection{References}

Abrantes, F., Loncaric, N., Moreno, J., Mil-Homens, M., \& Pflauman, U. (2001). Paleoceanographic conditions along the Portuguese Margin during the last $30 \mathrm{ka}$ : A multiple proxy study. Comunicações Do Instituto Geológico e Mineiro, 88, $161-184$. 
Adler, J. \& Parmryd, I. (2010). Quantifying colocalization by correlation: The Pearson Correlation Coefficient is superior to the Mander's Overlap Coefficient. Cytometry, 77A, 33-742.

Altabet, M.A. (1988). Variations in nitrogen isotopic composition between sinking and suspended particles: Implications for nitrogen cycling and particle transformation in the open-ocean. Deep Sea Research Part A, Oceanographic Research Papers, 35(4),535-554. https://doi.org/10.1016/0198-0149(88)90130-6

Altabet, M.A., Francois, R., Murray, D.W., \& Prell, W.L. (1995). Climate-related variations in denitrification in the Arabian Sea from sediment ${ }^{15} \mathrm{~N} /{ }^{14} \mathrm{~N}$ ratios. Nature, 373(6514), 506-509. https://doi.org/10.1038/373506a0

Be, A.W.H. (1977). An ecological, zoogeographic and taxonomic review of recent planktonic foraminifera. Oceanic Micropaleontology, 1, 1-100.

Bé, A.W.H. \& Hutson, W.H. (1977). Ecology of planktonic foraminifera and biogeographic patterns of life and fossil assemblages in the Indian Ocean. Micropaleontology, 23(4), 369. https://doi.org/10.2307/1485406

Black, H.D., Anderson, W.T., \& Alvarez-Zarikian, C. (2018). Data report: Organic matter, carbonate, and stable isotope stratigraphy from IODP Expedition 346 Sites U1426, U1427, and U1429. Proceedings of the Ocean Drilling Program, 346. doi:10.2204/iodp.proc.346.204.2018

Bubenshchikova, N., Nurnberg, D., Lembke-Jene, L., \& Pavlova, G. (2008). Living benthic foraminifera of the Okhotsk Sea, faunal composition, standing stocks and microhabitats. Marine Micropalenotology, 69, 314-333. https://doi.org/10.1016/j.marmicro.2008.09.002

Bubenshchikova, N., Nürnberg, D., \& Tiedemann, R. (2015). Variations of Okhotsk Sea oxygen minimum zone: Comparison of foraminiferal and sedimentological records for latest MIS 12-11c and latest MIS 2-1. Marine Micropaleontology, 121,52-69. https://doi.org/10.1016/j.marmicro.2015.09.004

Calvert, S.E., Nielsen, B., \& Fontugne, M.R. (1992). Evidence from nitrogen isotope ratios for enhanced productivity during formation of eastern Mediterranean sapropels.Nature, 359(6392), 223-225. https://doi.org/10.1038/359223a0

Chapman, M.R., Shackleton, N.J., Zhao, M., \& Eglinton, G. (1996). Faunal and alkenone reconstructions of subtropical North Atlantic surface hydrography and paleotemperature over the last 28 kyr. Paleoceanography, 11(3), 343-357. https://doi.org/10.1029/96PA00041 
Chen, C.A. (1996). The Kuroshio intermediate water is the major source of nutrients on the East China Sea continental shelf. Oceanologica Acta, 19, 523-527.

Conan, S.H. \& Brummer, G.J.A. (2000). Fluxes of planktic foraminifera in response to monsoonal upwelling on the Somalia Basin margin. Deep-Sea Research Part II: Topical Studies in Oceanography, 47(9-11), 2207-2227. https://doi.org/10.1016/S0967-0645(00)00022-9

Coplen, T.B. (2011). Guidelines and recommended terms for expression of stableisotope-ratio and gas-ratio measurement results. Rapid Communications in Mass Spectrometry, 25(17). https://doi.org/10.1002/rcm.5129

Domitsu, H. \& Oda, M. (2005). Japan Sea planktic foraminifera in surface sediments: Geographical distribution and relationships to surface water mass.

Paleontological Research, 9(3), 255-270. https://doi.org/10.2517/prpsj.9.255

Emerson, S. \& Hedges, J.I. (1988). Processes controlling the organic carbon content of open-ocean sediments. Paleoceanography, 3(5), 621-634. https://doi.org/10.1029/PA003i005p00621

Farrell, J.W., Pedersen, T.F., Calvert, S.E., \& Nielsen, B. (1995). Glacial-interglacial changes in nutrient utilization in the equatorial Pacific Ocean. Nature,377, 514517. https://doi.org/10.1038/377514a0

Finney, B.P., Lyle, M.W., \& Heath, G.R. (1988). Sedimentation at MANOP Site H (eastern equatorial Pacific) over the past 400,000 years: Climatically induced redox variations and their effects on transition metal cycling. Paleoceanography, 3(2), 169-189. https://doi.org/10.1029/PA003i002p00169

Fry, B. \& Sherr, E.B. (1984). ${ }^{13}$ C measurements as indicators of carbon flow in marine and freshwater ecosystems. Contributions in Marine Science, 27, 13-47. DOI: 10.1007/978-1-4612-3498-2_12

Gallagher, S.J., Kitamura, A., Iryu, Y., Itaki, T., Koizumi, I., \& Hoiles, P. W. (2015). The Pliocene to recent history of the Kuroshio and Tsushima Currents: A multi-proxy approach. Progress in Earth and Planetary Science, 2(1), 17. https://doi.org/10.1186/s40645-015-0045-6

Gallagher, S.J., Sagawa, T., Henderson, A., Saavedra-Pellitero, M., de Vleeschouwer, D., Black, H.D., et al. (2018). East Asian monsoon history and paleoceanography of the Japan Sea over the last 460,000 years. Paleoceanography and Paleoclimatology, 33(7), 683-702. https://doi.org/10.1029/2018PA003331 
Gallagher, S.J., Wallace, M.W., Li, C.L., Kinna, B., Bye, J.T.Akimoto, K., et al. (2009). Neogene history of the West Pacific Warm Pool, Kuroshio and Leeuwin currents. Paleoceanography and Paleoclimatology, 24(1).

Gamo, T. (2011). Dissolved oxygen in the bottom water of the Sea of Japan as a sensitive alarm for global climate change. TrAC - Trends in Analytical Chemistry, 30(8), 1308-1319. https://doi.org/10.1016/j.trac.2011.06.005

Gamo, T. \& Horibe, Y. (1983). Abyssal circulation in the Japan Sea. Journal of the Oceanographical Society of Japan, 39(5), 220-230.

https://doi.org/10.1007/BF02070392

Hase, H., Yoon, J.H., \& Koterayama, W. (1999). The current structure of the Tsushima Warm Current along the Japanese coast. Journal of Oceanography, 55(2), 217235. https://doi.org/10.1023/A:1007894030095

Hayes, J.M. (1982). Fractionation et al.: An introduction to isotopic measurements and terminology. Spectra, 8, 3-8.

Huang, B., Jian, Z., Cheng, X., \& Wang, P. (2003). Foraminiferal responses to upwelling variations in the South China Sea over the last 220000 years. Marine

Micropaleontology, 47(1-2), 1-15. https://doi.org/10.1016/S0377-8398(02)00045-2

Irino, T., Tada, R., Ikehara, K., Sagawa, T., Karasuda, A., Kurokawa, S., et al. (2018). Construction of perfectly continuous records of physical properties for dark-light sediment sequences collected from the Japan Sea during Integrated Ocean Drilling Program Expedition 346 and their potential utilities as paleoceanographic studies. Progress in Earth and Planetary Science, 5(23). https://doi.org/https://doi.org/10.1186/s40645-018-0176-7

Isobe, A. (1998). On the origin of the Tsushima Warm Current and its seasonality. Continental Shelf Research, 19(1), 117-133. https://doi.org/10.1016/S02784343(98)00065-X

Isobe, A., Ando, M., Watanabe, T., Senjyu, T., Sugihara, S., \& Manda, A. (2002). Freshwater and temperature transports through the Tsushima-Korea Straits. Journal of Geophysical Research, 107, 3065. https://doi.org/10.1029/2000JC000702

Itaki, T. (2016). Transitional changes in microfossil assemblages in the Japan Sea from the Late Pliocene to Early Pleistocene related to global climatic and local tectonic events. Progress in Earth and Planetary Science, 3(1), 11. https://doi.org/10.1186/s40645-016-0087-4 
Jian, Z., Huang, B., Kuhnt, W., \& Lin, H.L. (2001). Late Quaternary upwelling intensity and East Asian Monsoon forcing in the South China Sea. Quaternary Research, 55(3), 363-370. https://doi.org/10.1006/qres.2001.2231

Joliffe, I.T. (2002). Principal Component Analysis. Geography, 2. Springer: New York. https://doi.org/10.1002/0470013192.bsa501

Khim, B.K., Ikehara, K., Bahk, J.J., \& Irino, T. (2008). Increased negative anomolies of sedimentary organic matter $\delta^{13} \mathrm{C}$ and $\delta^{15} \mathrm{~N}$ values in the East Sea (Sea of Japan) during the full glaciation of the late Quaternary. Quaternary Internation, 176, 2535. DOI: $10.1016 /$ j.quaint.2007.05.016

Kim, C.-O. \& Yoon, J.-H. (1999). A numerical modeling of the upper and the intermediate layer circulation in the East Sea. Journal of Oceanography, 55(2), 327-345.

Kitamura, A. \& Kimoto, K. (2006). History of the inflow of the warm Tsushima Current into the Sea of Japan between 3.5 and $0.8 \mathrm{Ma}$. Palaeogeography, Palaeoclimatology, Palaeoecology, 236(3-4), 355-366. https://doi.org/10.1016/j.palaeo.2005.11.015

Koizumi, I. (1992). Diatom biostratigraphy of the Japan Sea: Leg 127. Proceedings of the Ocean Drilling Program, Scientific Results, 127/128(1), 249-289. https://doi.org/doi.org/10.1594/PANGAEA.771031

Kuroyanagi, A. \& Kawahata, H. (2004). Vertical distribution of living planktonic foraminifera in the seas around Japan. Marine Micropaleontology, 53(1-2), 173196. https://doi.org/10.1016/j.marmicro.2004.06.001

Kuroyanagi, A., Kawahata, H., \& Ohkushi, K. (2006). Reconstruction of paleoceanographic changes based on the relationship between planktonic foraminiferal assemblages and water masses off Shimokita over the last 27,000 years. Fossils, (79), 33-42.

Lee Chen, Y.L., Lu, H.B., Shiah, F.K., Gong, G.C., Liu, K.K., \& Kanda, J. (1999). New production and F-ratio on the continental shelf of the East China Sea: Comparisons between nitrate inputs from the subsurface Kuroshio Current and the Changjiang River. Estuarine, Coastal and Shelf Science, 48(1), 59-75. https://doi.org/10.1006/ecss.1999.0404

Lee, K.E., Bahk, J.J., \& Narita, H. (2003). Temporal variations in productivity and planktonic ecological structure in the East Sea (Japan Sea) since the last glaciation. Geo-Marine Letters, 23(2), 125-129. https://doi.org/10.1007/s00367003-0132-3 
Lehmann, M.F., Bernasconi, S.M., Barbieri, A., McKenzie, J.A. (2002). Preservation of organic matter and alteration of its carbon and nitrogen isotope composition during simulated and in situ early sediment diagenesis. Geochimica et Cosmochimica Acta, 66(20), 3573-3584. https://doi.org/10.1016/S00167037(02)00968-7

Liu, W., Baudin, F., Moreno, E., Dewilde, F., Caillon, N., Fang, N., et al. Comparison of $240 \mathrm{ka}$ long organic carbon and carbonate records along a depth transect in the Timor Sea: Primary signals versus preservation changes. Paleoceanography, 29, 389-402. doi:10.1002/2013PA002539.

McKinney, C.R., McCrea, J.M., Epstein, S., Allen, H.A., \& Urey, H.C. (1950). Improvements in mass spectrometers for the measurement of small differences in isotope abundance ratios. Review of Scientific Instruments, 21(724). https://doi.org/10.1063/1.1745698

Meyers, P.A. (1994). Preservation of elemental and isotopic source identification of sedimentary organic matter. Chemical Geology. https://doi.org/10.1016/00092541(94)90059-0

Meyers, P.A. (1997). Organic geochemical proxies of paleoceanographic, paleolimnologic, and paleoclimatic processes. In Organic Geochemistry, 27, 213-250. https://doi.org/10.1016/S0146-6380(97)00049-1

Miao, Q. \& Thunell, R.C. (1996). Late Pleistocene-Holocene distribution of deep-sea benthic foraminifera in the South China Sea and Sulu Sea: Paleoceanographic implications. The Journal of Foraminiferal Research, 26(1), 9-23. https://doi.org/10.2113/gsjfr.26.1.9

Minoura, K., Hoshino, K., Nakamura, T., \& Wada, E. (1997). Late Pleistocene-Holocene paleoproductivity circulation in the Japan Sea: Sea-level control on $\delta^{13} \mathrm{C}$ and $\delta^{15} \mathrm{~N}$ records of sediment organic material. Palaeogeography, Palaeoclimatology, Palaeoecology, 135(1-4), 41-50. https://doi.org/10.1016/S0031-0182(97)00026-6

Müller, P.J. \& Suess, E. (1979). Productivity, sedimentation rate, and sedimentary organic matter in the oceans-I. Organic carbon preservation. Deep Sea Research PartA, Oceanographic Research Papers, 26(12), 1347-1362. https://doi.org/10.1016/0198-0149(79)90003-7

Nagashima, K., Tada, R., \& Toyoda, S. (2013). Westerly jet-East Asian Summer Monsoon connection during the Holocene. Geochemistry, Geophysics, Geosystems, 14(12), 5041-5053. https://doi.org/10.1002/2013GC004931 
Oba, T., Kato, M., Kitazato, H., Koizumi, I., Omura, A., Sakai, T., \& Takayama, T. (1991). Paleoenvironmental changes in the Japan Sea during the last 85,000 years. Paleoceanography, 6(4), 499-518. https://doi.org/10.1029/91PA00560

Oda, M., \& Takemoto, A. (1992). Planktonic foraminifera and paleoceanography in the domain of the Kuroshio Current around Japan during the last 20,000 years. The Quaternary Research, 31, 341-357. DOI: 10.4116/jaqua.31.341

O'Leary, M.H. (1981). Carbon isotope fractionation in plants. Phytochemistry, 20(4), 553-567. https://doi.org/10.1016/0031-9422(81)85134-5

Pearson, K. (1901). On lines and planes of closest fit to systems of points in space. Philosophy Magazine, 6(2), 559-572.

Pedersen, T.F. (1983). Increased productivity in the eastern equatorial Pacific during the last glacial maximum (19000-14000 yr B.P.). Geology, 11(1971), 16-19. https://doi.org/10.1130/0091-7613(1983)11<16:IPITEE >2.0.CO;2

Peterson, B.J. \& Howarth, R.W. (1987). Sulfur, carbon, and nitrogen isotopes used to trace organic matter flow in the salt-marsh estuaries of Sapelo Island, Georgia. Limnology and Oceanography, 32(6), 1195-1213. https://doi.org/10.4319/1o.1987.32.6.1195

Peterson, B.J. \& Fry, B. (1987). Stable isotopes in ecosystem studies. Annual Review of Ecology and Systematics, 18, 293-320. https://doi.org/10.1146/annurev.es.18.110187.001453

Prell, W.L. (1984). Variation of Monsoonal Upwelling: A Response to Changing Solar Radiation. Climate Processes and Climate Sensitivity, 29. https://doi.org/10.1029/GM029p0048

Reynolds, L.A. \& Thunnell, R.C. (1985). Seasonal succession of planktonic foraminifera in the subpolar North Pacific. The Journal of Foraminiferal Research, 15(4), 282301 .

Rohling, E.J., Jorissen, F.J., \& De stigter, H.C. (1997). 200 year interruption of Holocene sapropel formation in the Adriatic Sea. Journal of Micropalaeontology, 16(2), 97-108. https://doi.org/10.1144/jm.16.2.97

Saavedra-Pellitero, M., Baumann, K.-H., Gallagher, S.J., Sagawa, T., \& Tada, R. (In press). Paleoceanographic evolution of the Japan Sea over the last $430 \mathrm{kyr}-\mathrm{A}$ coccolithophore perspective. Marine Micropaleontology.

Sagawa, T., Nagahashi, Y., Satoguchi, Y., Holbourn, A., Itaki, T., Gallagher, S.J., et al. (2018). Integrated tephrostratigraphy and stable isotope stratigraphy in the Japan 
Sea and East China Sea using IODP Sites U1426, U1427 and U1429, Expedition 346 Asian Monsoon. Progress in Earth and Planetary Science, 5(18). https://doi.org/10.1186/s40645-018-0168-7

Salgueiro, E., Voelker, A., Abrantes, F., Meggers, H., Pflaumann, U., Lončarić, N., et al. (2008). Planktonic foraminifera from modern sediments reflect upwelling patterns off Iberia: Insights from a regional transfer function. Marine Micropaleontology, 66(3-4), 135- 164. https://doi.org/10.1016/j.marmicro.2007.09.003

Sato, N. \& Moriyama, T. (2018). Photosynthesis. In Cyanidioschyzon merolae: A New Model Eukaryote for Cell and Organelle Biology. https://doi.org/10.1007/978981-10-6101- 1_17

Schonfeld, J. (2006). Taxonomy and distribution of Uvigerina peregrina plexus in the tropical to northeastern Atlantic. Journal of Foraminiferal Research, 36(4), 355367. https://doi.org/10.2113/gsjfr.36.4.355

Schubert, C.J. \& Calvert, S.E. (2001). Nitrogen and carbon isotopic composition of marine and terrestrial organic matter in Arctic Ocean sediments: Implications for nutrient utilization and organic matter composition. Deep-Sea Research Part I: Oceanographic Research Papers, 48(3), 789-810. https://doi.org/10.1016/S09670637(00)00069-8

Singh, A.D., Verma, K., Jaiswal, S., Alonso-Garcia, M., Li, B., \& Abrantes, F. (2015). Planktic foraminiferal responses to orbital scale oceanographic changes off the western Iberian margin over the last 900kyr: Results from IODP Site U1391. Global and Planetary Change, 135, 47-56. https://doi.org/10.1016/j.gloplacha.2015.10.002

Spratt, R.M. \& Lisiecki, L.E. (2016). A Late Pleistocene sea level stack. Climate of the Past, 12(4), 1079-1092. https://doi.org/10.5194/cp-12-1079-2016

Stefanelli, S., Capotondi, L., \& Ciaranfi, N. (2005). Foraminiferal record and environmental changes during the deposition of the Early-Middle Pleistocene sapropels in southern Italy. Palaeogeography, Palaeoclimatology, Palaeoecology, 216(1-2), 27-52. https://doi.org/10.1016/j.palaeo.2004.10.001

Stein, R. (1991). Accumulation of organic carbon in marine sediments. Berlin: Springer.

Stevenson, F.J., \& Cole, M.A. (1999). Cycles of soil: carbon, nitrogen, phosphorus, sulfur, micronutrients. Wiley, New Jersey. https://doi.org/10.1038/ncomms9384

Tada, R., Irino, T., Koizumi, I. (1999). Land-ocean linkages over orbital and millennial timescales recorded in Late Quaternary sediments of the Japan Sea.

Paleoceanography, 14(2), 236-247. https://doi.org/10.1029/1998PA900016 
Tada, R., Koizumi, I., Cramp, A., Rahman, A. (1992). Correlation of dark and light layers, and the origin of their cyclicity in the Quaternary sediments from the Japan Sea. Proceedings of the Ocean Drilling Program Scientific Results, 127, 577-601. DOI: 10.2973/odp.proc.sr.127128-1.160.1992

Tada, R., Murray, R.W., Alvarez Zarikian, C.A., Anderson, W.T., Brace, B.J., et al. 2015). Expedition 346 Summary. Proceedings of the Ocean Drilling Program, 346. doi:10.2204/iodp.proc.346.101.2015

Tada, R., Murray, R.W., Alvarez Zarikian, C.A., Anderson W.T., Bassetti, M.-A., Brace, B.J., et al. (2015). Methods. Proceedings of the Ocean Drilling Program, 346. doi:10.2204/iodp.proc.346.102.2015

Tada, R. (1994). Paleoceanographic evolution of the Japan Sea. Palaeogeography, Palaeoclimatology, Palaeoecology, 108(3-4), 487-508. https://doi.org/10.1016/0031-0182(94)90248-8

Tada, R. (2004). Onset and evolution of millennial-scale variability in the Asian Monsoon and its impact on paleoceanography of the Japan Sea. In Geophysical Monograph Series, 149, 283-298. https://doi.org/10.1029/149GM15

Tada, R., Irino, T., Ikehara, K., Karasuda, A., Sugisaki, S., Xuan, C., et al. (2018). Highresolution and high-precision correlation of dark and light layers in the Quaternary hemipelagic sediments of the Japan Sea recovered during IODP Expedition 346. Progress in Earth and Planetary Science, 5(19). https://doi.org/10.1186/s40645-018- 0167-8

Takikawa, T., \& Yoon, J.H. (2005). Volume transport through the Tsushima Straits estimated from sea level difference. Journal of Oceanography, 61(4), 699-708. https://doi.org/10.1007/s10872-005-0077-4

Tesdal, J.E., Galbraith, E.D., \& Kienast, M. (2013). Nitrogen isotopes in bulk marine sediment: Linking seafloor observations with subseafloor records.

Biogeosciences, 10(1), 101-118. https://doi.org/10.5194/bg-10-101-2013

Thunell, R.C. \& Sautter, R.L. (1992). Planktonic foraminiferal faunal and stable isotopic indices of upwelling: A sediment trap study in the San Pedro Basin, Southern California Bight. Geological Society Special Publications, (64), 77-91. https://doi.org/10.1144/GSL.SP.1992.064.01.05

Usami, K., Ohi, T., Hasegawa, S., \& Ikehara, K. (2013). Foraminiferal records of bottomwater oxygenation and surface-water productivity in the southern Japan Sea during 160-15ka: Associations with insolation changes. Marine Micropaleontology, 101, 10-27. https://doi.org/10.1016/j.marmicro.2013.03.006 
Wada, E., Kabaya, Y., Tsuru, K., \& Ishiwatari, R. (1990). ${ }^{13} \mathrm{C}$ and ${ }^{15} \mathrm{~N}$ abundance of sedimentary organic matter in estuarine areas of Tokyo Bay, Japan. Journal of the Mass Spectrometry Society of Japan, 38(6), 307-318. https://doi.org/10.5702/massspec.38.307

Wang, P. (1999). Response of Western Pacific marginal seas to glacial cycles: Paleoceanographic and sedimentological features. Marine Geology, 156(1-4), 539. https://doi.org/10.1016/S0025-3227(98)00172-8

Wang, P., Clemens, S., Beaufort, L., Braconnot, P., Ganssen, G., Jian, Z., et al. (2005). Evolution and variability of the Asian Monsoon system: State of the art and outstanding issues. Quaternary Science Reviews, 24, 595-629. https://doi.org/10.1016/j.quascirev.2004.10.002

Watanabe, S., Tada, R., \& Ikehara, K.. (2007). Sediment fabrics, oxygenation history, and circulation modes of Japan Sea during the Late Quaternary. Palaeogeography, Palaeoclimatology, Palaeoecology, 247, 50-64. https://doi.org/10.1016/j.palaeo.2006.11.021

Watanabe, T., Katoh, O., \& Yamada, H. (2006). Structure of the Tsushima Warm Current in the northeastern Japan Sea. Journal of Oceanography, 62(4), 527-538. https://doi.org/10.1007/s10872-006-0073-3

Wold, S., Esbensen, K., \& Geladi, P. (1987). Principal component analysis. Chemometrics and Intelligent Laboratory Systems, 2(1-3), 37-52. https://doi.org/10.1016/0169-7439(87)80084-9

Xu, X. \& Oda, M. (1999). Surface-water evolution of the eastern East China Sea during the last 36,000 years. Marine Geology, 156(1-4), 285-304. https://doi.org/10.1016/S0025-3227(98)00183-2

Yihui, D., \& Chan, J.C.L. (2005). The East Asian Summer Monsoon: An overview. Meteorology and Atmospheric Physics, 89, 117-142. https://doi.org/10.1007/s00703-005-0125-z 


\section{CHAPTER 3: THE MID-PLEISTOCENE TRANSITION AND THE RESULTING PALEOPRODUCTIVITY CYCLES WITHIN THE JAPAN SEA ${ }^{5}$}

\subsection{Abstract}

Japan Sea sediments serve as an ideal medium to record changes in paleoceanographic conditions because of the clear difference in their characteristics between glacial and interglacial periods. Through the use of elemental $\left(\% \mathrm{CaCO}_{3}, \% \mathrm{TOC}\right.$, and $\% \mathrm{TN})$ and isotopic $\left(\delta^{13} \mathrm{C}\right.$ and $\left.\delta^{15} \mathrm{~N}\right)$ analysis, temporal changes in relative paleoproductivity levels were reconstructed during the last $\sim 1.3 \mathrm{Ma}$ at IODP Expedition 346 Site U1426 in the Japan Sea, with increased primary production during interglacial periods in comparison to glacial periods. The interpreted paleoproductivity signal, as a result of the East Asian Summer Monsoon, has been shown to shift dominant orbital frequencies during the Mid-Pleistocene Transition ( $700 \mathrm{ka}$ to $1.2 \mathrm{Ma})$, from a higher frequency 21-33 ky periodicity to a lower frequency 100 ky periodicity without any changes in external orbital forces. The current study identifies an apparent shift in the periodicity of paleoproductivity cycles at or near the Matuyama-Brunhes paleomagnetic boundary $(\sim 774 \mathrm{ka})$ in all five proxies studied, indicating that the Mid-Pleistocene Transition affected not only glacial/interglacial periodicity but primary paleoproductivity cycles in surface waters as well.

\footnotetext{
${ }^{5}$ To be submitted to Progress in Earth and Planetary Sciences. Black, H.D., Anderson,
} W.T., and Tada, R. 


\subsection{Introduction}

The East Asian Monsoon (EAM) is an important component of the global climate system since its geographical area covers nearly one-third of the global population. The EAM has two primary components, the East Asian Summer Monsoon (EASM) which brings warm, humid air and increased precipitation, and the East Asian Winter Monsoon (EAWM) which increases aridity and eolian inputs to the region (Wang et al., 2005). The regulation of the EAM has previously been shown to be related to different orbital cycles, e.g., eccentricity ( 100 ky), obliquity ( 41 ky) and precession ( 19 and $\sim 21 \mathrm{ky})($. Through spectral analysis, these orbital rhythms can be extracted from continuous sedimentary sequences to determine if and when a shift in dominance occurred in these orbital parameters (De Boer \& Smith, 2009; Hays et al., 1976).

During the Mid-Pleistocene Transition (MPT), a low-frequency, high-amplitude, quasi-periodic signal ( $\sim 100 \mathrm{ky})$ emerged from a previous higher-frequency, loweramplitude signal ( $\sim 1 \mathrm{ky}$ ) without any changes in external orbital forcing (Clark et al., 2006; Heslop et al., 2002), leading to an abrupt global cooling. Although a well-accepted precise date has not yet defined the MPT, it has been documented to begin at $\sim 1.2 \mathrm{Ma}$ and was complete by $700 \mathrm{ka}$ (Clark et al., 2006; Head \& Gibbard, 2015). Within the Pacific, Shackelton and Opdyke (1976) were the first to identify the MPT within a single paleomagnetic boundary layer, the Matuyama-Brunhes, at $774 \mathrm{ka}$. The MPT not only shifted the dominant orbital signal from $\sim 41 \mathrm{ky}$ to $\sim 100 \mathrm{ky}$, but also brought about a global cooling through decreased sea surface temperatures $\left(\sim 2.2^{\circ} \mathrm{C}\right)$ and increased ice volume by up to 50\% (Clark et al., 2006; Dwyer et al., 1995; Heslop et al., 2002). 
Within the EAM region specifically, the MPT increased monsoon intensity (Clark et al., 2006; Li et al., 2017). The EAM is caused by seasonal variations within continental and oceanic temperatures and the resulting air pressure gradients (Nakagawa et al., 2008). During the summer, low pressure areas form over the continents as a result of differential heating, which results in winds transporting moisture inland. In contrast, during the winter, a high pressure system forms over the continents which increases aridity and eolian transport to the oceans (Guo, 1983). During periods of increased monsoon intensity, enhanced EASM is associated with increased precipitation ( $\sim 30 \%$ although it varies geographically; Lu et al., 2018) and wetter conditions with over $80 \%$ of the annual precipitation occurring during the monsoon season (Wang 2001). Enhanced EAWM, however, is associated with an increased eolian influx 2.5 times greater than summer conditions, and therefore drier conditions (Weber et al., 2018; Zhang et al., 2018).

Multiple proxies have been used to reconstruct the intensity of the EASM throughout the MPT. Speleothem $\delta^{18} \mathrm{O}$ has been used to reconstruct precipitation intensity (Cheng et al., 2016; Clemens et al., 2018; Li et al., 2017; Thomas et al., 2016; Wang et al., 2008), grain size analysis of eolian materials to determine wind strength (Clemens et al., 1996; Sun et al., 2006), and abundance of eolian material to determine aridity (Clemens et al., 1996; Tiedemann et al., 1994); all showing increased monsoon intensity and strength beginning at the start of the MPT. To serve as a reliable proxy, relatively undisturbed, continuous sequences with a well-defined age model are necessary to reconstruct the timing and effects of the MPT. Therefore, the carbon and nitrogen geochemistry of sediment cores recovered from Integrated Ocean Drilling Program (IODP) Expedition 346 in the Japan Sea would serve as an ideal proxy to study the MPT 
within the EAM system, specifically how the EASM's precipitation variations influenced net primary productivity within the phototrophic zone.

The Japan Sea is a semi-enclosed marginal sea between the Japanese archipelago, the Korean Peninsula, and Russia with an area greater than 1,000,000 $\mathrm{km}^{2}$ and an average depth of 1,350 $\mathrm{m}$ (Figure 3.1). The sea is unique in that it is connected to surrounding water bodies only though shallow, narrow straits. The most significant influx of water into the Japan Sea is through the Tsushima Strait (130 m depth), with outflow to the Pacific Ocean through the Tsugaru Strait (130 m depth) and the Sea of Okhotsk through the Soya Strait (55 m depth) and Mamiya Strait (15 m depth)(Takikawa \& Yoon, 2005). The shallow depths of these sills have a significant control on the amount of current influx into the sea. During significant glacio-eustatic sea level drops during glacial low stands, the Japan Sea can be nearly isolated from the surrounding water bodies and the predominant influx of water is from precipitation and continental runoff (Tada et al., 1999; Watanabe et al., 2007). At present, the only current flowing into the Japan Sea is the Tsushima Warm Current (TWC) through the Tsushima Strait (Hase et al., 1999). 


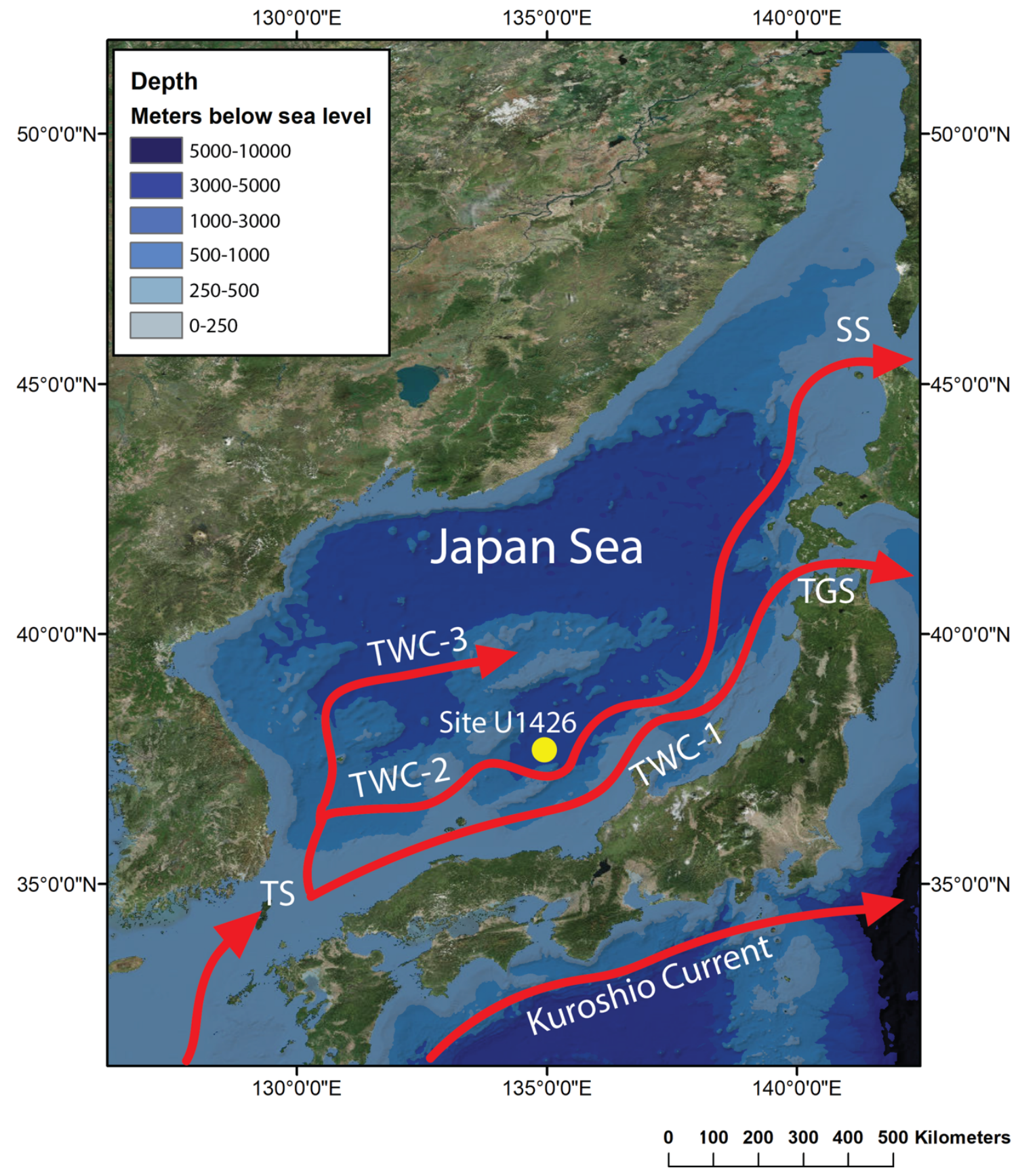

Figure 3.1. Map of the Japan Sea, the modern current system, and Site U1426. TS = Tsushima Strait; TGS = Tsugaru Strait; SS = Soya Strait; MS = Mamiya Strait; TWC-1, TWC-2, TWC-3 are the first, second, and third branch of the Tsushima Warm Current, respectively. The map was created using ArcMap 10.3 (Modified from Gallagher et al., 2018.) 
The TWC forms in the East China Sea by the mixing of the nutrient-poor Kuroshio Current and the low salinity, nutrient-rich East China Sea Coastal Water (ECSCW)(Isobe, 1998; Isobe et al., 2002). Although the Kuroshio Current is generally nutrient-poor $\left(\mathrm{NO}_{3}<0.1 \mu \mathrm{mol} \mathrm{kg}{ }^{-1} ; \mathrm{P}_{4}<0.02 \mu \mathrm{mol} \mathrm{kg}{ }^{-1} ; \mathrm{Si}_{2}<1 \mu \mathrm{mol} \mathrm{kg}{ }^{-1}\right)$, the Kuroshio Intermediate Water upwells as a result of estuary circulation (Chen et al., 1999), increasing bio-limiting nutrient loads, especially phosphorous ( $\mathrm{NO}_{3} \sim 25 \mu \mathrm{mol} \mathrm{kg}{ }^{-1}$; $\left.\mathrm{P}_{4} \sim 1.7 \mu \mathrm{mol} \mathrm{kg}{ }^{-1} ; \mathrm{SiO}_{2} \sim 60 \mu \mathrm{mol} \mathrm{kg}^{-1}\right)($. The ECSCW salinity and nutrient concentrations are correlated with the discharge of Yangtze (Changjiang) and Yellow (Huang He) Rivers (Isobe, 1998; Isobe et al., 2002). A higher proportion of the Kuroshio Intermediate flows through the southern channel of the Tsushima Strait while a higher proportion of the ECSCW flows through the northern channel (Itaki, 2016). At present, the TWC has a flow volume of 1.1 to $2.6 \mathrm{~Sv}$ (Isobe, 1998) with a surface velocity of 0.3$0.4 \mathrm{~ms}^{-1}$ (Takikawa \& Yoon, 2005).

After the TWC has entered the Japan Sea, it separates into three branches (Hase et al., 1999; Watanabe et al., 2006). The first, and largest, segment flows northeasterly along the coast of Honshu Island and eventually exits through the Tsugaru Strait. The second branch is similar to the northeasterly flow of the first branch but is closer to the center of the Japan Sea. The third branch flows along the coast of the Korean Peninsula until it moves easterly towards the center of the Japan Sea. While the first branch of the TWC has a relatively constant flow volume, the second and third branches vary seasonally, with significant volume reduction during the winter (Kim \& Yoon, 1999; Tada, 1994). During the winter, the cold and dense Japan Sea Proper Water (JSPW) is formed in the northern Japan Sea as a result of sea ice formation off Vladivostok, Russia 
(Kawamura \& Wu, 1998). The JSPW has a relatively low salinity (34) and high dissolved oxygen concentrations $(>200 \mu \mathrm{mol} / \mathrm{kg}$ ). It currently covers all of the Japan Sea at depths $>300 \mathrm{~m}$, leading to highly oxic bottom waters (Oba et al., 1991).

The narrow, shallow sills that connect the Japan Sea to the surrounding water bodies cause significant differences in oceanographic conditions depending on sea level and oceanic influx. During glacio-eustatic sea level variation, the volume and source of water currents into the sea changes significantly (Figure 3.2)(Oba et al., 1991; Tada et al., 1999). During glacial periods when the sill depth of the Tsushima Strait is $<40 \mathrm{~m}$, reduced sea levels limit the inflow of water through the Tsushima Strait, which can nearly isolate the Japan Sea from the surrounding seas (Lee et al., 2003; Oba et al., 1991; Wang, 1999). With limited current influx, the predominant water source is precipitation and surface runoff from the surrounding land masses, significantly reducing the surface layer salinity ( 28) and increasing water column stratification (Oba et al., 1991, Watanabe et al., 2007). With reduced vertical mixing that results from the higher salinity gradient, suboxic to euxinic deep-water environments persist, which generally lead to better preservation of organic material at the sediment-water interface (Tada et al., 1999; Usami et al., 2013; Watanabe et al., 2007). Sea levels between approximately 40 to 110 $m$ introduce a varying combination of the TWC and ECSCW flowing into the Japan Sea (Tada et al., 1999). The high nutrient concentrations from the ECSCW (Chen et al., 1999) promote higher levels of net primary productivity in surface waters, i.e., rates of phytoplankton production minus the oxidation of organic matter. In contrast, the higher salinity TWC increases vertical mixing within the water column, leading to oxic to suboxic bottom water environments (Watanabe et al., 2007). Increasing contribution of 
the ECSCW when compared to the TWC, however, decreases vertical mixing as a result of the salinity gradient, which leads to suboxic to euxinic conditions (Tada et al., 1999). Sea level high stands that have a sill depth $>110 \mathrm{~m}$ in the Tsushima Strait allow a significant influx of the TWC, leading to thorough vertical mixing and oxic bottom water conditions.

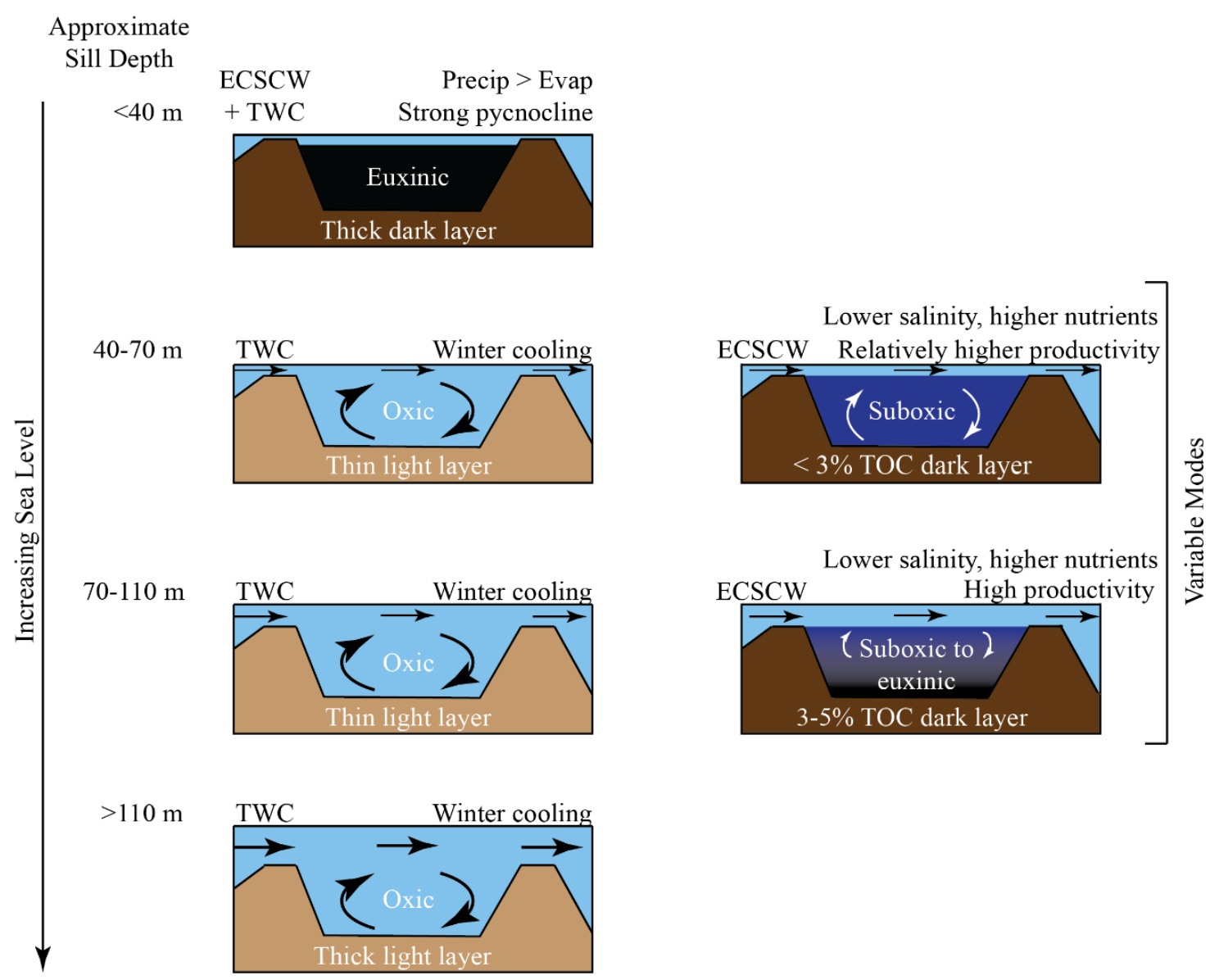

Figure 3.2. Concept diagram of circulation and oxygenation modes within the Japan Sea as a result of increasing sea level and varying ocean current influx. (Modified from Tada et al., 1999.)

Paleoproductivity is also linked to the variation in the influx of oceanic currents during glacial/interglacial periods. Interglacial periods lead to increased net productivity as a result of the increased influx of the ECSCW and TWC in comparison to glacial 
periods (Black et al., 2018). Through the analysis of $\mathrm{C}$ and $\mathrm{N}$ concentrations preserved in sediment, as well as their respective stable isotopic ratios, paleoproductivity levels can be reconstructed where increased paleoproductivity is inferred by increased concentrations of the bio-limiting nutrients C and N (Fry \& Sherr, 1984; Peterson \& Fry, 1987). In respect to their stable isotopic ratios, phytoplankton typically incorporate more of the light isotope (i.e., ${ }^{12} \mathrm{C}$ and ${ }^{14} \mathrm{~N}$ ) into their via biologic fractionation (Fry $\&$ Sherr, 1984). With increased net primary productivity, nutrient competition increases leading the surface waters and the resulting organic matter production, to become isotopically enriched over time (Peterson \& Fry, 1987).

Although all five of the geochemical parameters can be used to infer qualitative paleoproductivity rates, they each have advantages and disadvantages in regard to their use. For example, carbonate content $\left(\% \mathrm{CaCO}_{3}\right)$, is affected by the depth of the calcite compensation depth (CCD), where dissolution of carbonate occurs at a greater rate than the supply due to understauration and increased solubility with depth, preventing the preservation of carbonate (Farrell \& Prell, 1989). Therefore, it is likely to have better preservation of carbonate materials at shallower sites above the CCD than deeper depths. Eolian input also has a direct influence on the $\% \mathrm{CaCO}_{3}$ preserved within ocean sediment. In the Japan Sea specifically, significant eolian input is expected as the eolian dust from central Asia as the sea is only $2500 \mathrm{~km}$ away from the Gobi and Taklimakan deserts (Irino \& Tada, 2000). The organic matter content in coastal ocean sediments is rarely entirely autochthonous in nature, but instead is influenced by terrestrial organic material input as well, affecting both \%TOC and \%TN. Bottom water conditions also significantly affect the organic matter content in sediments as oxidation of sediment in oxic water 
columns degrade the deposited organic matter. Suboxic to euxinic bottom waters, however, lead to better preservation of organic matter as bacterial degradation is limited. Total nitrogen is not only affected by terrestrial organic matter influx, but inorganic eolian influx as well, as $\mathrm{NH}_{4}^{+}$sorbs to clay-rich particles like Kosa (Shigemitsu et al., 2009), such that arid conditions would increase inorganic $\mathrm{N}$ concentration in sediments.

The isotopic parameters are also affected by terrestrial vs. marine input. The $\delta^{13} \mathrm{C}$ values can differentiate marine (approximately -20\%) and terrestrial (approximately $-27 \%$ ) sources and different terrestrial vegetation types (e.g., $\mathrm{C}_{3}$ vs $\mathrm{C}_{4}$ plants)(O'Leary, 1981). Nitrogen stable isotope $\left(\delta^{15} \mathrm{~N}\right)$ values are affected by inorganic $\mathrm{N}$ contribution, like Kosa, such that $\delta^{15} \mathrm{~N}$ values are typically lower in inorganic nitrogen compounds than in organic nitrogen (Shigemitsu et al., 2009). Locations with significant inorganic N flux, like the Japan Sea, would therefore be expected to have lower $\delta^{15} \mathrm{~N}$ values than predominately organic $\mathrm{N}$ sediments. The nitrogen cycle is fairly complex with bacterial processes converting $\mathrm{N}$ between forms, such as nitrification of $\mathrm{NH}_{3}$ to $\mathrm{NO}_{3}$ - and denitrification of $\mathrm{NO}_{3}$ - to $\mathrm{N}_{2}$. Each $\mathrm{N}$ conversion introduces isotopic fractionation that can significantly affect the $\delta^{15} \mathrm{~N}$ values preserved in the geologic record (Altabet et al., 1995, 1999).

In the present study, the relative paleoproductivity levels within the Japan Sea using bulk $\mathrm{C}$ and $\mathrm{N}$ concentrations and their respective $\delta^{13} \mathrm{C}$ and $\delta^{15} \mathrm{~N}$ ratios will be reconstructed. Numerous studies (Crundwell et al., 2008; Heslop et al., 2002; MedinaElizalde \& Lea, 2005) have already highlighted the shift in orbital frequencies at the MPT, but so far few have analyzed stable isotopes of sediment samples from marginal Asian seas (Kitamura \& Kawagoe, 2006; Kitaba et al., 2011; Li et al., 2008; Li et al., 
2017). Since the Japan Sea serves as an ideal location to study the variation in paleoceanographic conditions resulting from glacio-eustatic sea level variations, it should allow for a well dated and high-resolution paleoproductivity reconstruction. The objective of the study is to determine if the MPT has been recorded in the paleoproductivity signal and how the orbital frequencies behaved before and after the MPT in the Japan Sea.

\subsection{Study Site}

Site U1426 is located in the Yamato Basin at $37^{\circ} 2.00^{\prime} \mathrm{N}, 134^{\circ} 48.00^{\prime} \mathrm{E}$ and 903 meters below sea level (mbsl), the same location as Ocean Drilling Program (ODP) Site 798 (Tada et al., 2015). The site is situated near the second branch of the TWC, which is a highly meandering current characterized by eddies (Hase et al., 1999). A total of four holes were drilled at Site U1426 with a recovery greater than $770 \mathrm{~m}$ of sediment (Tada et al., 2015). The sedimentary record covers the Pliocene to Holocene ( 5 My) and consists of clay and silty clay (Sagawa et al., 2018). Although the abundance of biogenic silica and calcareous microfossils vary in millennial-scale throughout the core, this site has relatively high concentrations of both organic and inorganic carbon compared to other Expedition 346 sites as a result of the shallow depth. Several tephra layers are interbedded within the stratigraphic record (Irino et al., 2018; Sagawa et al., 2018; Tada et al., 2018), which enables more precise dating and age model production. 
All samples used in this study are from Unit $1^{6}$, with nearly all contained within Subunit 1A, which consists of clay, silty clay, and nannofossil-rich clay with several diatomaceous and calcareous-rich layers throughout the core (Tada et al., 2015). Like most other Expedition 346 sites, Site U1426 shows clear centimeter- to decimeter-scale alternation of light and dark colored sediment (Irino et al., 2018; Tada et al., 2018). The light intervals are typically organic poor, moderately to heavily bioturbated, and mostly contain light greenish gray and pale yellowish gray diatomaceous-rich clay (Irino et al., 2018; Tada et al., 2015). The dark intervals are typically organic-rich, usually laminated, and consist of clay that is occasionally calcareous. While the upper $\sim 45 \mathrm{~m}$ of the core typically had clear color banding, lower portions were moderately bioturbated (Sagawa et al., 2018).

Previous studies (Tada et al., 1994, 1999, 2004; Watanabe et al., 2007) suggest that the meter-scale variability of sediment color is related to sea level variation between glacial and interglacial periods. Centimeter-scale color variability, in contrast, is caused by the current influx through the Tsushima Strait and the resulting nutrient concentrations reflecting changes in Yangtze River discharge into the East China Sea. Light colored sediment was generally deposited during oxic conditions associated with increased influx of the TWC while dark colored sediment was deposited during suboxic to euxinic conditions with limited current influx or increased contribution from the ECSCW in comparison to the TWC (Figure 3.2)(Tada et al., 1999; Watanabe et al., 2007). Laminated layers were deposited during both glacial low stands and intermediate sea

\footnotetext{
${ }^{6}$ See Chapter 1 for Unit 1 lithology description.
} 
levels. Euxinic conditions during glacial low stands resulted in dark laminated layers when the Japan Sea was nearly isolated from any current influx and precipitation was the most substantial input into the sea (Khim et al., 2007; Tada et al., 1994, 1999; Watanabe 2007). Laminated layers also develop in TOC-rich dark layers during intermediate sea levels, likely a result of high nutrient influx through the Tsushima Strait and strong upwelling conditions (Crusius et al., 1999; Khim et al., 2008). Yet, sediment color depends on the amount of organic matter production in addition to the oxidation state of the bottom waters. Dark (light) colored sediment can be representative of a high (low) rate of primary productivity or decreased (increased) oxygenation levels. The study aims to be one of the first to determine relative rates of primary productivity in the Japan Sea with records longer than $1 \mathrm{Ma}$ to gain a better understanding of the relationship between dark and light color banding, productivity rates, and oxidation state.

\subsection{Methods}

All $\% \mathrm{CaCO}_{3}, \% \mathrm{TOC}, \delta^{13} \mathrm{C}, \% \mathrm{TN}$, and $\delta^{15} \mathrm{~N}$ samples were analyzed within Florida International University's Southeastern Environmental Research Center's Stable Isotope Laboratory (SERC-SIL). All samples $(\mathrm{n}=136)$ were dried overnight at $60^{\circ} \mathrm{C}$, ground until fine, and homogenized using a Spex 8000M mixer/mill. Samples prepared for carbon isotope analysis were decarbonated using a $10 \% \mathrm{HCl}$ solution three times followed by decantation in deionized water (DI) three times to remove any acidic residue. Each decarbonation or decantation bath lasted for $\sim 24$ hours. Samples prepared for nitrogen isotope analysis were analyzed in bulk. Five mg of decarbonated sediment was used for $\% \mathrm{TOC}$ and $\delta^{13} \mathrm{C}$ analysis while $15 \mathrm{mg}$ of bulk sediment was used for $\% \mathrm{TN}$ and $\delta^{15} \mathrm{~N}$ 
analysis. Each sample was compacted in $5 \times 9 \mathrm{~mm}$ tin capsules and analyzed in an NA 1500 elemental analyzer (EA) coupled to a Thermo Delta C isotope ratio mass spectrometer (IRMS).

All isotopic data is expressed with delta notation $(\delta \%)$, using the equation:

$$
\delta \mathrm{R}=\left[\left(\mathrm{R}_{\text {sample }}-\mathrm{R}_{\text {standard }}\right) / \mathrm{R}_{\text {standard }}\right] * 1000 \quad \text { Eq. } 1
$$

where $R_{\text {sample }}$ is the ratio of the heavy to light isotope in the sample and $R_{\text {standard }}$ is the ratio of the heavy to light isotope in the standard (McKinney et al., 1950; Hayes, 1982; Coplen, 2011). The isotopic data of carbon and nitrogen is reported in parts per mil (\%) vs. VPDB and AIR, respectively. Precision $(1 \sigma)$ was better than $\pm 0.1 \%$ for organic carbon and $\pm 0.3 \%$ for nitrogen on the basis of analysis of standards over a range of isotopic values (Appendix 1). Thirty-two samples were analyzed in duplicate with precision better than $\pm 0.08 \%$ and $\pm 0.22 \%$ for carbon and nitrogen, respectively.

Inorganic carbon was analyzed by use of a UIC CM140 Coulometer using $15 \mathrm{mg}$ of dried, homogenized sediment which was acidified in $10 \mathrm{~mL}$ of $10 \% \mathrm{HClO}_{4}$. Calcium carbonate concentration $\left(\% \mathrm{CaCO}_{3}\right)$ was calculated from the inorganic carbon concentration by multiplying by a factor of 8.33 under the assumption that all inorganic carbon acts as $\mathrm{CaCO}_{3}$. Precision $(1 \sigma)$ was better than $\pm 0.17 \% \mathrm{CaCO}_{3}$ using analysis of Fisher Chemical's pure calcium carbonate standard $\left(\mathrm{CaCO}_{3}=100.09\right)$ and Nacalai Tesque's pure sodium carbonate standard $\left(\mathrm{Na}_{2} \mathrm{CO}_{3}=105.99\right)$. Twenty-nine samples were analyzed in duplicate with precision better than $\pm 0.68 \% \mathrm{CaCO}_{3}$.

The construction of continuous sedimentary sequences for Site U1426 was completed by use of the splicing technique, which correlates lightness ( $\left.\mathrm{L}^{*}\right)$, color $\left(\mathrm{b}^{*}\right)$, 
and physical properties between three holes at this site (Irino et al., 2018) ${ }^{7}$. All sample ages were calculated using the age model of Tada (2018), which focused on the correlation between dark and light layers, tephra layers, and magneto-stratigraphy at Site U1424, which were then projected to Site U1426. The regional tephra layers at Site U1426 include AT, Aso-4, Hkd-Ku, and Ss-Pink (Sagawa et al., 2018). The Hkd-Ku tephra layer, also known as the $\mathrm{K}_{\mathrm{U} 1}$ tephra (Satoguchi \& Nagahashi, 2012) is slightly above the Matuyama-Brunhes boundary at Site U1426. Lightness values $\left(\mathrm{L}^{*}\right)$ of the sediment were determined by use of color scanning imaging at a $5 \mathrm{~mm}$ resolution (Irino et al. 2018), where higher values indicate lighter sediment color. The $\delta^{18} \mathrm{O}$ values are from the high-resolution Pliocene-Pleistocene stack of benthic $\delta^{18} \mathrm{O}$ records (Lisiecki \& Raymo, 2005). An unpaired t-test was computed to compare glacial and interglacial differences between all five proxies $\left(\% \mathrm{CaCO} 3, \% \mathrm{TOC}, \% \mathrm{TN}, \delta^{13} \mathrm{C}\right.$, and $\left.\delta^{15} \mathrm{~N}\right)$ studied.

Quantitative statistical analyses included t-Tests, continuous wavelet analysis, and multitaper method analysis (MTM). A two-tailed t-Test for uneven variances was completed to determine if a significant difference exists between glacial and interglacial periods for $\mathrm{CaCO}_{3}, \mathrm{TOC}, \mathrm{TN}, \delta^{13} \mathrm{C}$, and $\delta^{15} \mathrm{~N}$. Continuous wavelet analysis was used to determine how the frequencies of the signals in paleoproductivity data changed in power over distinct periods of time (Torrence \& Compo, 1998) where warmer colors indicate increased cyclicity at that time period. A second signal analysis tool, MTM, was calculated to determine spectral density in more precise, quantitative frequencies found within the paleoproductivity signals (Thomson, 1982). For continuous wavelet and MTM

\footnotetext{
${ }^{7}$ Data was collected onboard the Joides Resolution by Expedition 346 Scientists. See Tada (2015) for more details.
} 
analyses, all data were interpolated to a constant sampling age of 9 ky and standardized by mean-centering and variance. Continuous wavelet analyses were completed using Matlab R2017b and its respective signal processing and wavelet toolboxes. Torrence \& Compo (1998) provided the wavelet analysis software. The MTM analysis was completed using $\mathrm{kSpectra}$ software using $\mathrm{p}=2$ and $\mathrm{K}=3$ and a significance test using an AR(1) null hypothesis (Ghil et al., 2002; Mann \& Lees, 1996). The continuous sequence of $\sim 1.3 \mathrm{My}$, as well as the subdivided sequences of 0-773 $\mathrm{ky}$ and 774-1314 ky, were used to determine the MPT defined at the Matuyama-Brunhes boundary (Shackelton and Opdyke, 1976). The LR04 global sea-level stack of benthic foraminifera $\delta^{18} \mathrm{O}$ values (Lisiecki \& Raymo, 2005) was included in continuous wavelet and MTM analyses as the orbital frequencies within their dataset have been extensively studied within the EAM impact area (Clemens et al., 1996, 2010; Tiedmann et al., 1994; Sun et al., 2006, 2015; Heslop et al., 2002; Weber et al., 2018; Thomas et al., 2016).

\subsection{Results}

Total organic carbon (TOC) contents average $2.6 \%$, which is relatively high for marine sediment (Emerson \& Hedges, 1988; Müller \& Suess, 1979). The variance in TOC contents is relatively small, ranging from $0.6 \%$ to $6.4 \%$. The mean value of total nitrogen (TN) was $0.2 \%$, which is relatively low for marine sediments and ranges from $0.0 \%$ to $0.4 \%$. Calcium carbonate contents $\left(\% \mathrm{CaCO}_{3}\right)$ average $8.6 \%$ and range from $0 \%$

to $44.3 \% \mathrm{CaCO}_{3}$. The carbon stable isotope ratio $\left(\delta^{13} \mathrm{C}\right)$ mean is $-22.3 \%$ ond ranges from $-25.9 \%$ to $-20.7 \%$ while the nitrogen isotopic ratio $\left(\delta^{15} \mathrm{~N}\right)$ averages $6.4 \%$ and ranges from 3.3\%o to $10.5 \%$ (Figure 3.3; Appendix 3). 

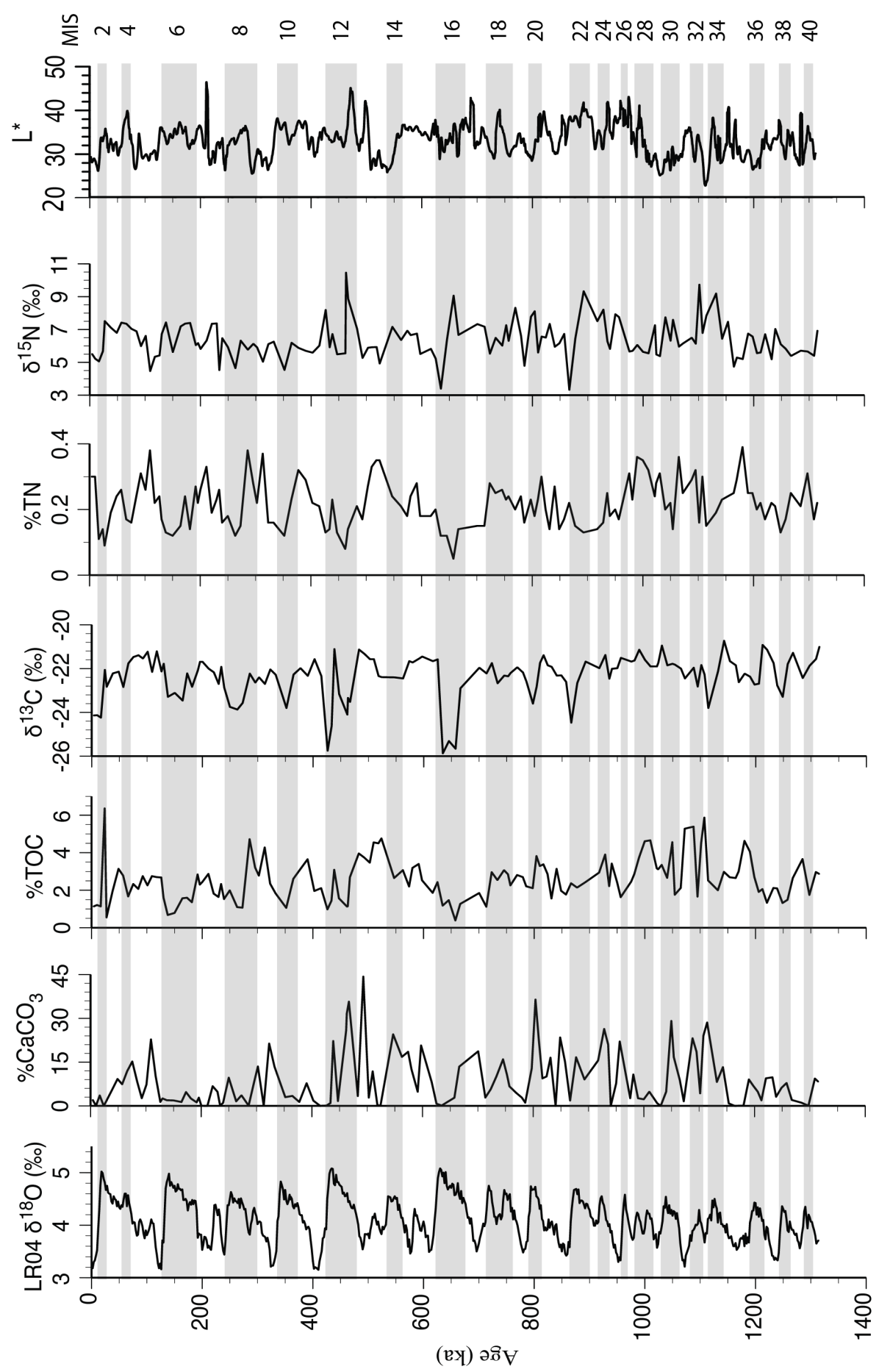

Figure 3.3. Measured $\% \mathrm{CaCO}_{3}, \% \mathrm{TOC}, \delta^{13} \mathrm{C}, \% \mathrm{TN}, \delta^{15} \mathrm{~N}$, and $\mathrm{L}^{*}$ values for Site U1426. $\delta^{18} \mathrm{O}$ values are from the LR04 benthic stack (Lisiecki and Raymo, 2005). Marine Isotope Stage (MIS) is indicated along secondary y-axis where glacial MIS periods are shaded in gray. 
The elemental and isotopic data indicate significant differences in values between glacial and interglacial periods (Figure 3.3). There was a significant difference in t-test scores for glacial and interglacial periods for $\% \mathrm{TOC}, \delta^{13} \mathrm{C}$, and $\% \mathrm{TN}$, but not for $\% \mathrm{CaCO}_{3}$ or $\delta^{15} \mathrm{~N}$ (Table 3.1). During glacial periods, $\% \mathrm{TOC}$ and $\% \mathrm{TN}$ generally decrease in concentration and $\delta^{13} \mathrm{C}$ is more depleted, whereas interglacial periods typically show increased concentration and isotopic enrichment for these proxies (Table 3.2). The isotopic data remains relatively constant throughout the study period except for glacial periods in which $\delta^{13} \mathrm{C}$ values typically become depleted while $\delta^{15} \mathrm{~N}$ shows both depletion and enrichment depending on the individual MIS period.

Table 3.1. T-test scores for $\% \mathrm{CaCO}_{3}, \% \mathrm{TOC}, \% \mathrm{TN}, \delta^{13} \mathrm{C}$, and $\delta^{15} \mathrm{~N}$ between glacial $(\mathrm{n}=65)$ and interglacial periods $(\mathrm{n}=71)$. In T-test analysis, $\mathrm{t}=\mathrm{t}$-value where larger values indicate significant differences between the sample mean and null hypothesis; $\mathrm{df}=$ degrees of freedom or the number of independent sample values; $p=$ probability value to determine statistical significance.

\begin{tabular}{llllll}
\hline & \%CaCO $_{\mathbf{3}}$ & \%TOC & \%TN & $\boldsymbol{\delta}^{\mathbf{1 3}} \mathbf{C}$ & $\boldsymbol{\delta}^{\mathbf{1 5}} \mathbf{N}$ \\
\hline $\mathbf{t}$ & 1.98 & 1.98 & 1.99 & 1.98 & 1.98 \\
$\mathbf{d f}$ & 120 & 117 & 87 & 128 & 112 \\
$\mathbf{p}$ & 0.10 & 0.04 & 0.00 & 0.00 & 0.14 \\
\hline
\end{tabular}

Table 3.2. The mean and variance of $\% \mathrm{CaCO}_{3}, \% \mathrm{TOC}, \% \mathrm{TN}, \delta^{13} \mathrm{C}$, and $\delta^{15} \mathrm{~N}$ between glacial $(\mathrm{n}=65)$ and interglacial periods $(\mathrm{n}=71)$ calculated in JMP software.

\begin{tabular}{llll}
\hline & & Glacial & Interglacial \\
\hline $\mathbf{\% C a C O}_{\mathbf{3}}$ & Mean (\%) & 10.05 & 7.41 \\
& Variance & 101.52 & 64.48 \\
$\mathbf{\%} \mathbf{T O C}$ & Mean (\%) & 2.39 & 2.79 \\
& Variance & 1.56 & 0.90 \\
$\mathbf{\%} \mathbf{T N}$ & Mean (\%) & 0.20 & 0.24 \\
& Variance & 0.01 & 0.00 \\
$\boldsymbol{\delta}^{\mathbf{1 3}} \mathbf{C}$ & Mean (\%) & -22.62 & -22.03 \\
& Variance & 1.40 & 0.30 \\
$\boldsymbol{\delta}^{\mathbf{1 5}} \mathbf{N}$ & Mean (\%) & 6.56 & 6.27 \\
& Variance & 1.75 & 0.86 \\
\hline
\end{tabular}


Continuous wavelet analysis power spectrums (Figure 3.4) indicates a significant shift in periodicity at the MPT for LR04 $\delta^{18} \mathrm{O}$ (Lisiecki \& Raymo, 2005), $\% \mathrm{CaCO}_{3}, \delta^{13} \mathrm{C}$, and $\delta^{15} \mathrm{~N}$ with minor changes in periodicity in $\% \mathrm{TOC}$ and $\% \mathrm{TN}$. The $100 \mathrm{ky}$ frequency begins at or near the MPT for $\delta^{18} \mathrm{O}, \% \mathrm{CaCO}_{3}, \delta^{13} \mathrm{C}$, and $\delta^{15} \mathrm{~N}$ while $\sim 40$ and $\sim 80 \mathrm{ky}$ periodicities dominate before the MPT (Tables $3.3 \& 3.4$ ). Within the \% TOC and \%TN power spectrums, minor shifts in periodicity occur near the MPT when an $\sim 80 \mathrm{ky}$ frequency ends $\sim 900-950 \mathrm{ka}$ and a $100 \mathrm{ky}$ frequency begins $\sim 600 \mathrm{ka}$. The $\delta^{13} \mathrm{C}$ power spectrum indicates limited cyclicity in all periods before the MPT and robust cyclicity after while the $\delta^{15} \mathrm{~N}$ power spectrum indicates complex cyclicity throughout the entire study period (Figure 3.4). 

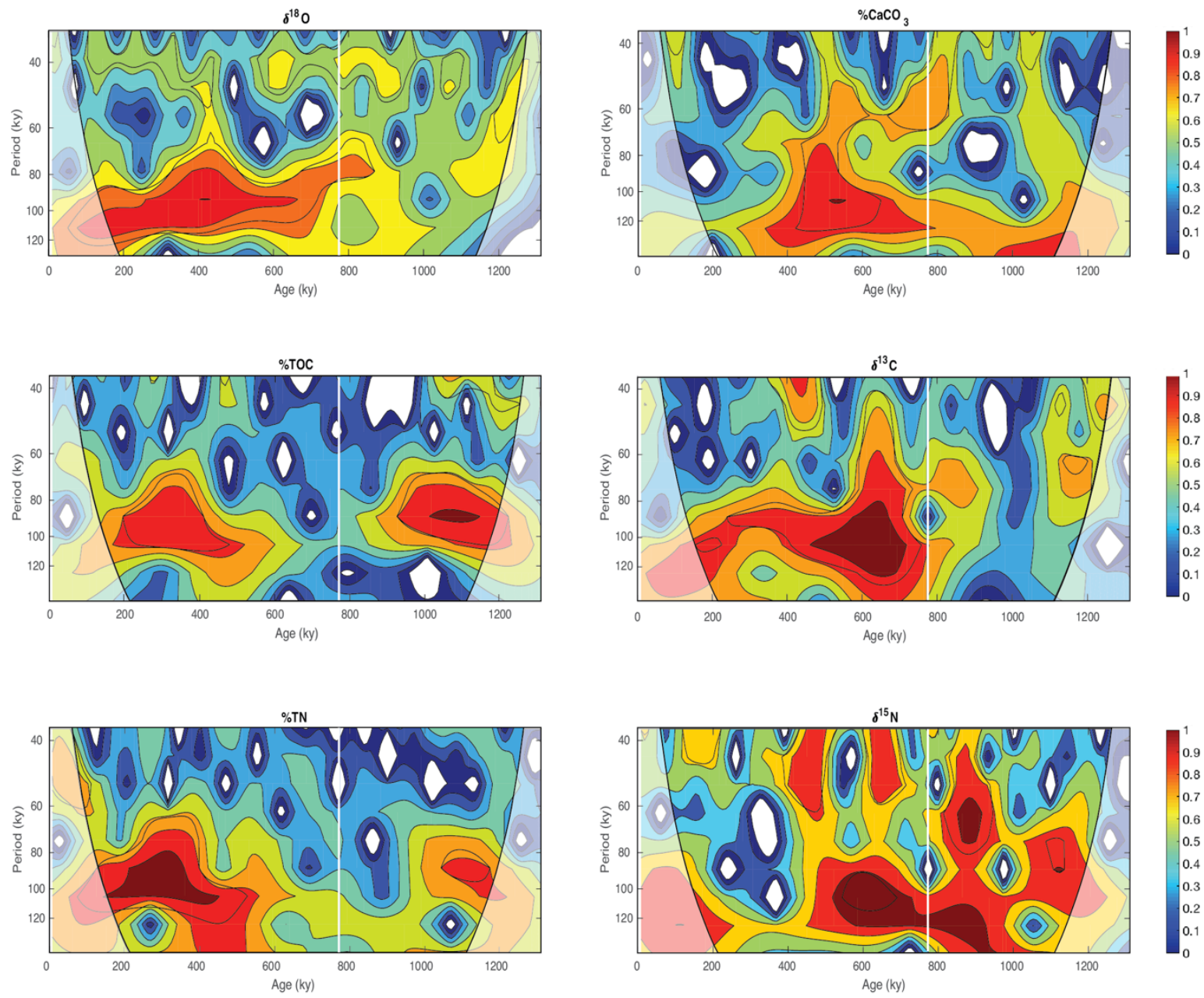

Figure 3.4. Continuous wavelet analysis of $\delta^{18} \mathrm{O}$ (LR04; Lisiecki \& Raymo, 2005) and $\% \mathrm{CaCO}_{3}, \% \mathrm{TOC}, \delta^{13} \mathrm{C}, \% \mathrm{TN}$, and $\delta^{15} \mathrm{~N}$ values for Site U1426. The solid black line indicates the $95 \%$ cone of influence. The solid white vertical line indicates the MPT at the Matuyama-Brunhes boundary, $\sim 774 \mathrm{ka}$.

Multitaper method (MTM) analyses for the period after the MPT (0-773 ka; Table 3.3) and before the MPT (774-1314 ka; Table 3.4) indicate a shift in spectral peaks during the MPT. Before the MPT, spectral peaks are dominated by higher frequency periods of $\sim 18,31-35$, and $40 \mathrm{ky}$. After the MPTthese periods continue but are dominated 
by lower frequencies of $\sim 90,99-100$, and $103 \mathrm{ky}$. In addition to orbital frequencies, heterodynes, or the interaction of two orbital periods were identified using the calculations of Thomas (2018) where:

$$
\pm \text { Heterodyne }^{-1}=\text { Period }^{-1} \pm \text { Period } 2^{-1} .
$$

Eq. 2

Table 3.3. Multitaper method (MTM) spectral analyses for the period after the MPT (0$773 \mathrm{ka}$ ) indicate cyclicity peaks in thousands of years (ky) for $\delta^{18} \mathrm{O}, \% \mathrm{CaCO}_{3}, \% \mathrm{TOC}$, $\delta^{13} \mathrm{C}, \% \mathrm{TN}$, and $\delta^{15} \mathrm{~N}$.

\begin{tabular}{llllll}
\hline $\boldsymbol{\delta}^{\mathbf{1 8}} \mathbf{O}$ & $\mathbf{\% C a C O}_{\mathbf{3}}$ & $\mathbf{\% T O C}$ & $\mathbf{\% T N}$ & $\boldsymbol{\delta}^{\mathbf{1 3}} \mathbf{C}$ & $\boldsymbol{\delta}^{\mathbf{1 5}} \mathbf{N}$ \\
\hline 99.2 & 63.6 & 90.4 & 99.2 & 101.4 & 103.0 \\
40.8 & 26.7 & 37.9 & 26.5 & 38.7 & 44.1 \\
22.9 & & 26.0 & 20.5 & & 37.0 \\
\hline
\end{tabular}

Table 3.4. Multitaper method (MTM) spectral analyses for the period before the MPT (774-1314 ka) indicate cyclicity peaks in thousands of years $(\mathrm{ky})$ for $\delta^{18} \mathrm{O}, \% \mathrm{CaCO}_{3}$, $\% \mathrm{TOC}, \delta^{13} \mathrm{C}, \% \mathrm{TN}$, and $\delta^{15} \mathrm{~N}$.

\begin{tabular}{llllll}
\hline $\boldsymbol{\delta}^{\mathbf{1 8}} \mathbf{O}$ & $\mathbf{\% C a C O}_{\mathbf{3}}$ & $\mathbf{\%} \mathbf{T O C}$ & $\mathbf{\% T N}$ & $\boldsymbol{\delta}^{\mathbf{1 3}} \mathbf{C}$ & $\boldsymbol{\delta}^{\mathbf{1 5}} \mathbf{N}$ \\
\hline 92.1 & 40.6 & 93.3 & 31.8 & 70.4 & 31.3 \\
64.3 & 35.4 & 35.4 & 23.2 & 40.0 & 18.0 \\
42.6 & 25.7 & 18.2 & 18.6 & 18.6 & \\
22.9 & & & & & \\
\hline
\end{tabular}



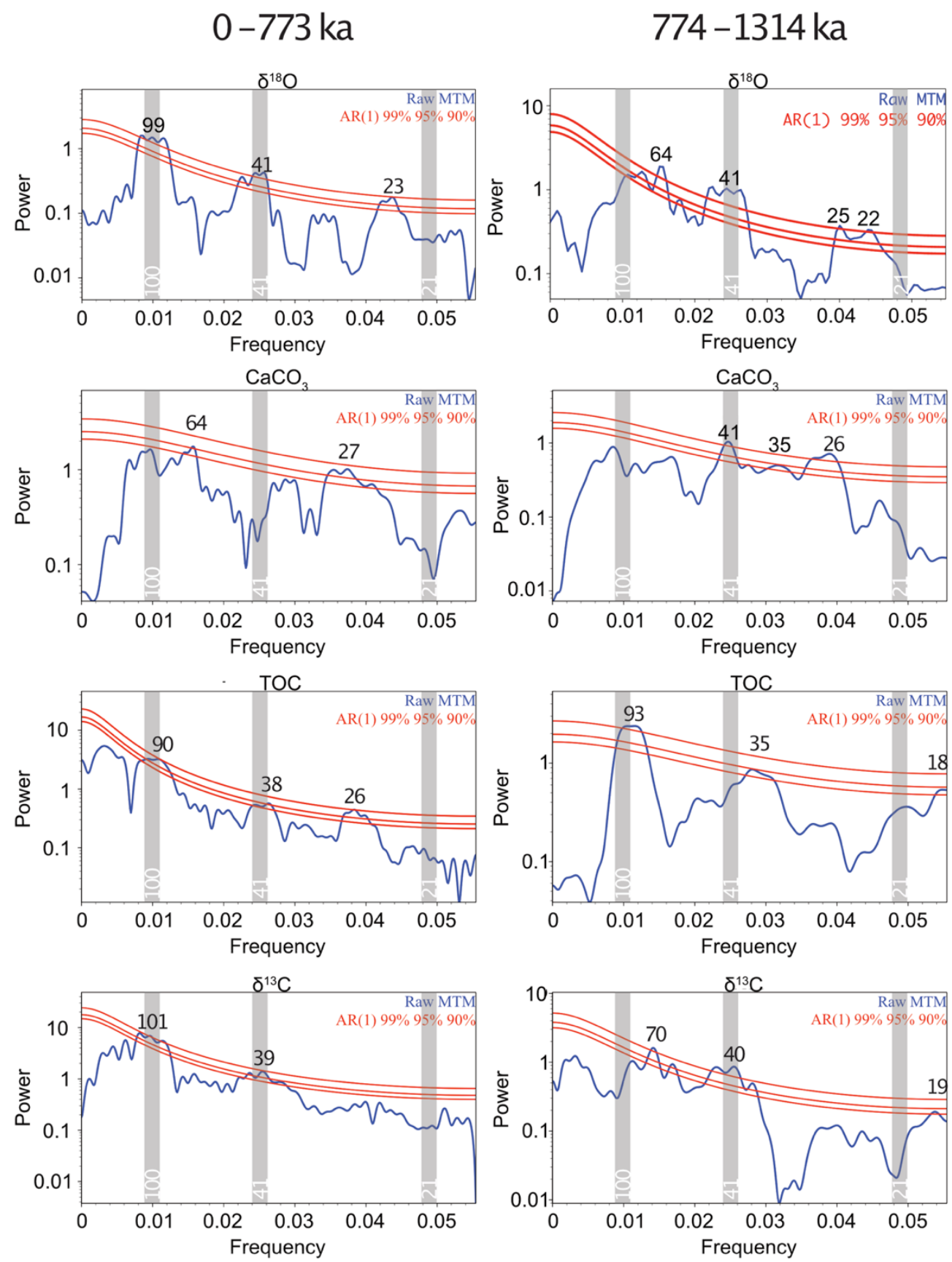

Figure 3.5. Multitaper method (MTM) spectral analysis of a) $\delta^{18} \mathrm{O}$ (LR04; Lisiecki \& Raymo, 2005), b) \% $\mathrm{CaCO}_{3}$, c) \%TOC, and d) $\delta^{13} \mathrm{C}$ values after the MPT (0-773 ka; left column) and before the MPT (774-1314 ka; right column). Red lines indicate AR(1) confidence intervals of $99 \%, 95 \%$, and $90 \%$ against robust red noise. Shaded gray areas indicate orbital frequencies of $\sim 100 \mathrm{ky}, 41 \mathrm{ky}$, and $21 \mathrm{ky}$. Individual spectral peaks are indicated numerically in ky units. 


\section{$0-773 \mathrm{ka}$}
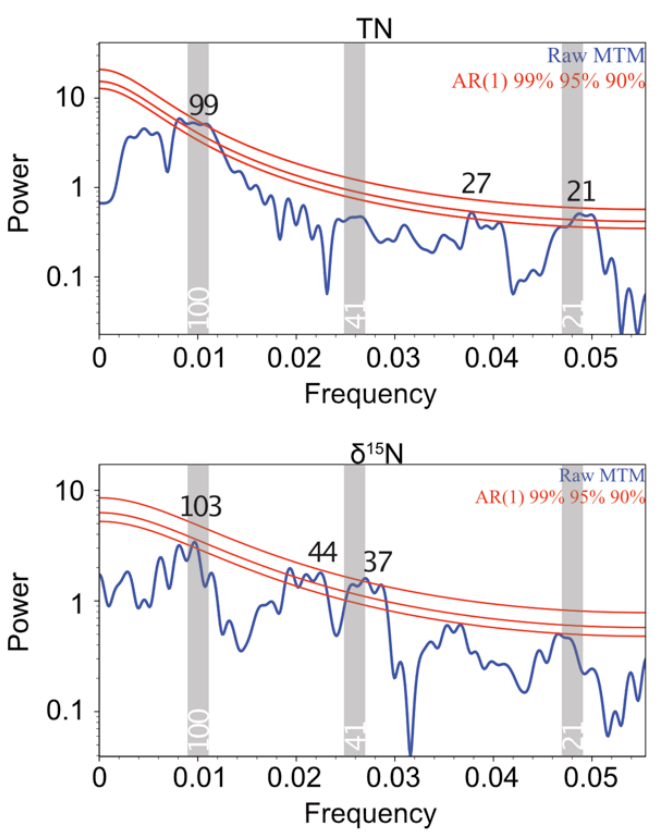

$774-1314 \mathrm{ka}$
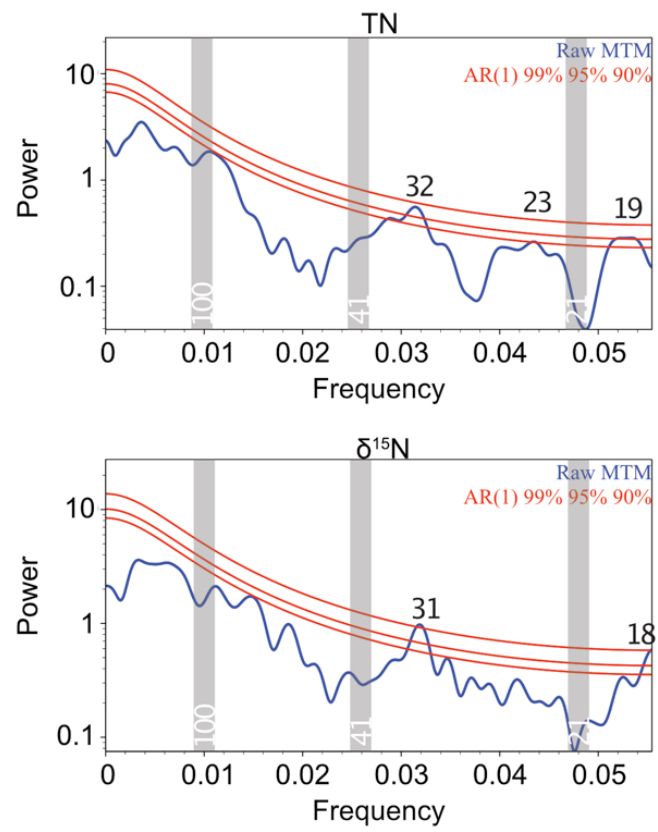

Figure 3.6. Multitaper method (MTM) spectral analysis of a) $\% \mathrm{TN}$ and b) $\delta^{15} \mathrm{~N}$ values after the MPT (0-773 ka; left column) and after the MPT (774-1314 ka; right column). Red lines indicate AR(1) confidence intervals of $99 \%, 95 \%$, and $90 \%$ against robust red noise. Shaded gray areas indicate orbital frequencies of $\sim 100 \mathrm{ky}, 41 \mathrm{ky}$, and $21 \mathrm{ky}$. Individual spectral peaks are indicated numerically in ky units.

Spectral analysis of the LR04 stack (Lisiecki \& Raymo, 2005) and Site U1426 after the MPT corroborates previous studies with a dominant $\sim 100$ ky frequency present (Table 3; Figures $3.5 \& 3.6$ ) except for $\% \mathrm{CaCO}_{3}$. The $\delta^{18} \mathrm{O}$ values (Lisiecki \& Raymo, 2005) are indicative of the well-established orbital frequencies (i.e., $100 \mathrm{ky}, 41 \mathrm{ky}$, and $23 \mathrm{ky}$ ) and no heterodynes are present. For $\% \mathrm{CaCO}_{3}$, two heterodynes are present after the MPT: $63.6 \mathrm{ky}$ and $26.7 \mathrm{ky}$. In the \%TOC data, one heterodyne is present, $37.9 \mathrm{ky}$. The identified $90.4 \mathrm{ky}$ and $36.0 \mathrm{ky}$ frequencies are neither primary orbital periods nor resulting heterodynes. For $\delta^{13} \mathrm{C}$, a 38.7 ky heterodyne is the present as well as a nonorbital 101.4 ky frequency. In the \%TN power spectrum, one likely orbital period is 
present, $99.2 \mathrm{ky}$, and two heterodynes are identified, $26.5 \mathrm{ky}$, and $20.5 \mathrm{ky}$. Finally, $\delta^{15} \mathrm{~N}$ indicates one heterodyne, $37.0 \mathrm{ky}$, and two unidentified orbital periods of $103.0 \mathrm{ky}$ and $44.1 \mathrm{ky}$.

Table 3.5. Heterodynes and their related primary orbital periods. Bold heterodynes represent the frequencies identified after the MPT (0-773 ka) at Site U1426. (Modified from Thomas et al., 2016.)

\begin{tabular}{llll}
\hline $\begin{array}{l}\text { +Heterodyne } \\
\text { (ky) }\end{array}$ & $\begin{array}{l}\text {-Heterodyne } \\
\text { (ky) }\end{array}$ & $\begin{array}{l}\text { Period 1 } \\
\text { (ky) }\end{array}$ & $\begin{array}{l}\text { Period 2 } \\
\text { (ky) }\end{array}$ \\
\hline 18.4 & $\mathbf{2 0 . 3}$ & 404.0 & 19.3 \\
$\mathbf{3 7 . 3}$ & 45.8 & 404.0 & 41.1 \\
19.1 & $\mathbf{2 7 . 0}$ & 130.6 & 22.4 \\
$\mathbf{6 3 . 6}$ & 2377.7 & 130.6 & 123.8 \\
$\mathbf{3 8 . 2}$ & 91.8 & 130.6 & 53.9 \\
13.1 & $\mathbf{3 6 . 4}$ & 41.1 & 19.3 \\
\hline
\end{tabular}

While the 100 ky period is significant in the geochemical data used at Site U1426 and the LR04 stack (Lisiecki \& Raymo, 2005) after the MPT, the spectral record is dominated by higher frequencies before the MPT and lacks any indication of a significant 100 ky period (Table 3.4; Figures $3.5 \& 3.6$ ). Frequencies identified within the $\delta^{18} \mathrm{O}$ data (Lisiecki \& Raymo, 2005) include one precession signal of 22.4 ky, one obliquity frequency of 41.1, and two heterodynes, $25.2 \mathrm{ky}$ and $64.0 \mathrm{ky}$. The $40.6 \mathrm{ky}$ frequency present in the $\% \mathrm{CaCO}_{3}$ data is likely an obliquity signal with increased error (e.g., $>0.5$ ky)(Thomas et al., 2016) while the $25.7 \mathrm{ky}$ and 35.5 ky periods are heterodynes. In \%TOC, two heterodynes were identified, $18.2 \mathrm{ky}$ and $35.4 \mathrm{ky}$ as well as a non-orbital frequency of $93.3 \mathrm{ky}$. Within the $\delta^{13} \mathrm{C}$ data, $18.6 \mathrm{ky}$ and $70.4 \mathrm{ky}$ heterodyne frequencies were identified as well as a non-orbital frequency of $39.0 \mathrm{ky}$. The spectral peaks in the nitrogen data are dominated by even higher frequency periods than in the carbon data. 
For $\% \mathrm{TN}$, the primary period of $23.2 \mathrm{ky}$ and two heterodynes, $18.6 \mathrm{ky}$ and $31.3 \mathrm{ky}$, were spectrally significant. The $\delta^{15} \mathrm{~N}$ power spectrum identifies two heterodynes, $18.0 \mathrm{ky}$ and $31.3 \mathrm{ky}$.

Table 3.6. Heterodynes and their related primary orbital periods. Bold heterodynes represent the frequencies identified before the MPT (774-1314 ka) at Site U1426. (Modified from Thomas et al., 2016.)

\begin{tabular}{lcll}
\hline $\begin{array}{l}\text { +Heterodyne } \\
\text { (ky) }\end{array}$ & $\begin{array}{l}\text {-Heterodyne } \\
\text { (ky) }\end{array}$ & $\begin{array}{l}\text { Period 1 } \\
\text { (ky) }\end{array}$ & $\begin{array}{l}\text { Period 2 } \\
\text { (ky) }\end{array}$ \\
\hline 22.4 & $\mathbf{2 5 . 2}$ & 404.0 & 23.7 \\
$\mathbf{3 4 . 9}$ & 118.7 & 98.7 & 53.9 \\
$\mathbf{1 8 . 3}$ & 29.0 & 98.7 & 22.4 \\
29.0 & $\mathbf{7 0 . 4}$ & 98.7 & 41.1 \\
19.0 & $\mathbf{3 1 . 6}$ & 94.8 & 23.7 \\
\hline
\end{tabular}

\subsection{Discussion}

Paleoproductivity levels can be interpreted through the use of $\% \mathrm{CaCO}_{3}, \% \mathrm{TOC}$, $\% \mathrm{TN}, \delta^{13} \mathrm{C}$, and $\delta^{15} \mathrm{~N}$ where increased concentration and isotopic enrichment indicate higher levels of net primary production occurring in the surface waters (Peterson \& Fry, 1987). During interglacial periods, $\% \mathrm{TOC}$ and $\% \mathrm{TN}$ increase in concentration by $0.40 \%$ and $0.04 \%$, respectively, while $\delta^{13} \mathrm{C}$ becomes enriched by $0.59 \%$, and $\delta^{15} \mathrm{~N}$ becomes either enriched or depleted depending on specific MIS periods (Figure 3.3), all of which indicate increased net primary production in comparison to glacial periods. During interglacial periods, there is a significant influx of water through the Tsushima Strait, which brings higher nutrient loads from the TWC and ECSCW that can support higher levels of productivity in the surface waters as compared to glacial periods (Tada et al., 1999). The influx of the TWC and ECSCW through the Tsushima Strait varies through 
time and depending on which current contributes the largest influx into the sea, can create oxic to euxinic bottom waters (Figure 3.2)(Tada et al., 1999). If the TWC dominates the current influx, the higher salinity current reduces stratification in the water column, allowing for thorough mixing and oxic bottom waters (Tada, 1994). If the ECSCW contributes a higher percentage of influx, in contrast, the resulting substantial contribution of Yangtze and Yellow River discharges within the current can lead a higher salinity gradient, which can stratify the water column, leading to suboxic to euxinic environments (Watanabe et al., 2007).

During glacial periods, however, a significant reduction in sea level can restrict current influx, leaving the Japan Sea nearly isolated, which results in freshening events with precipitation being the most significant contributor of water into the sea (Tada, 2004; Tada et al., 1999). Increased relative abundance of precipitation in comparison to current influx stratifies the water column as a result of the salinity differences between a fresher surface water and higher salinity deep-water (Tada, 1994). Increased stratification within the water column limits vertical mixing, which decreases net primary production as a result of limited upwelling of nutrients and creates anoxic to potentially euxinic bottom waters (Figure 3.2). In general, $\% \mathrm{CaCO}_{3}$ concentrations increase by $2.64 \%$ during glacial periods in comparison to interglacial periods as a result of deepening of the CCD during glacial periods (Kitazato, 1984; Tada et al., 1992). However, significant decreases in $\% \mathrm{CaCO}_{3}$ concentration during specific glacial periods, especially MIS 2 , MIS 6 , and MIS 16, indicates apparent dissolution of carbonate as a result of shallowing of the CCD during glacial low stands or relative dilution by siliciclastic material. 
Although the MPT has a broad range of accepted beginning and ending dates, by choosing the Matuyama-Brunhes boundary found within Site U1426 as a specific MPT transition point, it enables a clear differentiation of periodicity before and after the MPT since dated tephra layers bracket this layer at Site U1426 (Sagawa et al., 2018). For all geochemical proxies reported, shifts of periodicity occurred near $774 \mathrm{ka}$, but the most significant changes occur in $\% \mathrm{CaCO}_{3}$ and $\delta^{13} \mathrm{C}$, where the emergence of a $\sim 100$ ky period began shortly before the MPT ( $800 \mathrm{ka}$ )(Figure 3.4$)$. The wavelets of both $\%$ TOC and $\% \mathrm{TN}$ also see shifts in periodicity at the MPT, but the shift in frequency is much smaller from $\sim 80$ ky to $\sim 100$ ky periods. This $\sim 80$ ky periodicity before the MPT is likely the result of heterodynes, or the combination of primary orbital periods (Thomas et al., 2016). These two elemental proxies also experience a gap in periodicity from $\sim 900$ to $\sim 600 \mathrm{ka}$, which could be further explained by the wide range of MPT dates reported within published literature and the complex interaction of multiple environmental parameters during a broad transition period.

The wavelet for $\delta^{15} \mathrm{~N}$ (Figure 3.4) is more complicated than the other proxies studied, which is likely indicative of isotopic fractionation within the water column as a result of changes in microbial processes (e.g., denitrification) in anoxic to euxinic environmental conditions controlling the biogeochemistry (Altabet et al., 1995). Denitrification causes $\delta^{15} \mathrm{~N}$ values of sediment to typically become more enriched as a result of the bacterial conversion of dissolved nitrate to $\mathrm{N}_{2}$ (Altabet et al., 1995; 1999). The anoxic environment necessary for denitrification to occur would only be present during glacial low stands when lower paleoproductivity levels, and therefore more depleted $\delta^{15} \mathrm{~N}$ values, would be expected. In some glacial periods, like MIS 12, 
significant ${ }^{15} \mathrm{~N}$ enrichment occurs, indicating anoxic bottom waters instead of increased paleoproductivity. Although the emergence of the 100 ky frequency in $\delta^{15} \mathrm{~N}$ occurs earlier ( 1 Ma) than the other proxies, it still falls within accepted MPT dates.

To better understand the individual orbital frequencies found within continuous wavelet analyses in relation to the MPT, MTM spectral analysis was used to identify significant power spectrum peaks (Thomson, 1982) when compared to a robust red noise background (Mann \& Lees, 1996). An apparent shift from higher frequency periods before the MPT to lower frequency periods after the MPT was found in all five proxies studied (Figures $3.5 \& 3.6$ ), which identified the emergence of a $\sim 100$ ky frequency after the MPT except for \%TOC, in which the lowest frequency was $90 \mathrm{ky}$. Before the MPT, there are fewer identified peaks, likely as a result of the dominance of higher frequency signals, such as that of precession (i.e., $19.3 \mathrm{ky}, 22.4 \mathrm{ky}$, and $23.7 \mathrm{ky}$ ) periods.

Previous studies have noted the importance of the $100 \mathrm{ky}$ frequency in regard to controlling monsoonal climate as a result of its regulation of both glacial ice volume and polar atmospheric air temperature in recent $(<700 \mathrm{ky})$ sedimentary records (Imbrie et al., 1984; Guo et al., 2000; Nakagawa et al., 2008). Although the exact cause of the $100 \mathrm{ky}$ orbital frequency is still debated because of the lack of change in external orbital forcing, multiple theories exist in an attempt to explain the monsoonal cyclicity. Changes in direct solar forcing and the resulting variation in heating capacities between the Pacific Ocean and Eurasian continent are thought to be the main drivers of the 100 ky frequency (Kutzbach, 1981), while the precession cycle regulates boreal summer insolation (Boulay et al., 2005; Rossignol-Strick et al., 1998; Yuan et al., 2004) and the sea surface temperature of the Pacific (Beaufort et al., 2001). Other theories exist, however, that 
explain the complex interaction of all three orbital cycles (Clemens \& Prell, 2003; Lu et al., 2005) and the lead-lag relationship with monsoonal variation as a result of non-linear internal forcing mechanisms (Clemens \& Prell, 2007; Wang et al., 2005).

The cyclicity of the EASM has thoroughly been investigated using speleothem $\mathrm{CaCO}_{3} \delta^{18} \mathrm{O}$ (Clemens et al., 2010; Thomas et al., 2016; Wang et al., 2008) and loesspaleosol sequences from the Chinese Loess Plateau (Li et al., 2017; Sun et al., 2015) records to understand precipitation variability better. Few of these records, however, are long enough to identify the monsoonal cyclicity before the MPT. The sedimentary record from Site U1426 spans $\sim 1.3 \mathrm{My}$, which allows for investigation of paleoproductivity cyclicity both before and after the MPT. Since previous EASM cyclicity studies have predominately focused on more recent $(<450 \mathrm{ka})$ records, most have established the importance of the 100 ky frequency since the MPT, however, much is left unknown about the dominant cyclicity in the EASM before the MPT.

While most periodicities identified are correlated with previously published orbital periods or their related heterodynes (Thomas et al., 2016) within $\pm 0.5 \mathrm{ky}$, there are some spectral peaks identified at Site U1426 outside of these periods. After the MPT, $36.0 \mathrm{ky}, 44.1 \mathrm{ky}, 90.4 \mathrm{ky}, 101.4 \mathrm{ky}$, and $103.0 \mathrm{ky}$ periods are also present, all of which are neither primary periods nor heterodynes. Before the MPT, two additional non-orbital frequencies were identified, $39.0 \mathrm{ky}$, and $93.3 \mathrm{ky}$. These frequencies could be a result of numerous factors since the age model of Site U1426 was developed by the stratigraphic correlation of dark colored sediment and tephra layers between Sites U1424 and U1426 where the average time resolution of the age model is $\sim 6 \mathrm{ky}$. All non-orbital identified spectral peaks within MTM data are within \pm 4.4 ky of known periods and heterodynes, 
and the age discrepancies are likely a result of the stratigraphic correlation, or lack thereof, between Sites U1424 and U1426. In continuous wavelet and spectral analyses, the precision and resolution of the age model is critical to obtaining valid results. If a higher resolution age model is produced in the future, it is likely that the spectral results could change substantially. The constant sampling time used in spectral analyses could also affect the resulting frequencies (Ghil et al., 2002). In this study, a constant sampling time of 9 ky was interpolated from the geochemical parameters as the average sampling time was 9.4 ky throughout the record. Interpolation to a constant sampling time can increase the error, especially when large gaps exist between sample ages. Site U1426 (903 mbsl) is also one of the three shallowest sites from Expedition 346, which could possibly limit the distinction between light and dark sediment layers, similar to the presence of only subtle color banding at the shallowest Site U1427 (330 mbsl)(Sagawa et al., 2018).

The frequencies identified both before and after the MPT at Site U1426 (Figures $3.5 \& 3.6)$ indicate that orbital periods have a strong correlation with the elemental concentrations and isotopic values indicative of relative primary productivity. The well accepted 100 ky monsoonal period is present after the MPT, which reflects the importance of direct solar and glacial forcing and the resulting sea level variation in the amount of net primary production occurring within the Japan Sea. Before the MPT, however, the 18.3 ky heterodyne frequency is dominant in $\% \mathrm{TOC}, \delta^{13} \mathrm{C}, \% \mathrm{TN}$, and $\delta^{15} \mathrm{~N}$, likely as a result of monsoonal precipitation from the EASM (Boulay et al., 2005; Cruz et al., 2005; Rossignol-Strick et al., 1998; Ruddiman, 2006; Yuan et al., 2004). The use of elemental and isotopic proxies can therefore be used to identify relative paleoproductivity 
cycles within the Japan Sea. More research is necessaryto better understand the role of the EASM in the amount of net primary production occurring within the phototrophic zone.

\subsection{Conclusions}

The role of the EAM, specifically the EASM, has been extensively studied within East Asia to better understand the impact of the monsoon climate on precipitation within this densely populated region. Paleoproductivity levels as a result of the EASM have previously been shown to exhibit the 100 ky periodicity in recent geological records, but this study is one of the first to determine paleoproductivity levels and the resulting cyclicity of monsoon intensity in proxy records that are long enough to determine the influence and effect of the MPT within the Japan Sea.

Previous studies within marginal seas near the Pacific have shown a $100 \mathrm{ky}$ period in both paleoproductivity levels and monsoon intensity in relatively recent $(<700$ ka) speleothem and sedimentary records. A shift in the frequency of these orbital cycles occurred during the MPT, however, that caused the lower frequency 100 ky period to develop $\sim 700$ ka to 1.2 Ma from a higher frequency 41 ky period before the MPT without any changes in external orbital forcing. The MPT, defined as a specific date because of the presence of the Matuyama-Brunhes paleomagnetic boundary in Site U1426, has been identified in all six geochemical proxies used in this study $\left(\delta^{18} \mathrm{O}, \% \mathrm{CaCO}_{3}, \% \mathrm{TOC}, \delta^{13} \mathrm{C}\right.$, $\% \mathrm{TN}$, and $\delta^{15} \mathrm{~N}$ ) via continuous wavelet analysis, where a shift to lower frequency periods developed at or near the MPT. 
To better understand the underlying orbital frequencies within the periodicities of these proxies, MTM analysis was used to identify specific power spectrum peaks when compared to a robust red noise background. MTM analysis corroborated previous studies with a clear 100 ky frequency present after the MPT and higher frequency periodicities of $41 \mathrm{ky}$ and $21 \mathrm{ky}$ before the MPT. While specific orbital periods (i.e., eccentricity, obliquity, and precession) are found within the geochemical data, numerous heterodynes were also identified, which indicate a complex interaction between multiple environmental and oceanographic parameters before and after the MPT. The orbital periods identified in the relative paleoproductivity reconstruction implies direct relationships between solar and glacial forcing, sea level, current and nutrient influx through the Tsushima Strait, and surface productivity levels in the Japan Sea. Therefore, a connection between oceanographic controls and processes and orbital parameters exist within the Japan Sea since the Late Pleistocene.

\subsection{References}

Altabet, M.A., Murray, D.W., \& Prell, W.L. (1999). Climatically linked oscillations in Arabian Sea denitirification over the past 1 m.y.: Implications for the marine N cycle. Paleoceanography, 14(6), 732-743.

https://doi.org/10.1029/1999PA900035

Altabet, M.A., Francois, R., Murray, D.W., \& Prell, W.L. (1995). Climate-related variations in denitrification in the Arabian Sea from sediment ${ }^{15} \mathrm{~N} /{ }^{14} \mathrm{~N}$ ratios. Nature, 373(6514), 506-509. https://doi.org/10.1038/373506a0

Beaufort, L., De Garidel-Thoron, T., Mix, A.C., \& Pisias, N.G. (2001). ENSO-like forcing on oceanic primary production during the Late Pleistocene. Science, 293(5539), 2440-2444. https://doi.org/10.1126/science.293.5539.2440 
Black, H.D., Anderson, W.T., \& Alvarez-Zarikian, C. (2018). Data report: Organic matter, carbonate, and stable isotope stratigraphy from IODP Expedition 346 Sites U1426, U1427, and U1429. Proceedings of the Ocean Drilling Program, 346.

De Boer, P.L. \& Smith, D.G. (2009). Orbital forcing and cyclic sequences. In International Association of Sedimentologists Series. https://doi.org/10.1002/9781444304039.ch1

Boulay, S., Colin, C., Trentesaux, A., Frank, N., \& Liu, Z. (2005). Sediment sources and East Asian Monsoon intensity over the last $450 \mathrm{ky}$ : Mineralogical and geochemical investigations on South China Sea sediments. Palaeogeography, Palaeoclimatology, Palaeoecology, 228, 260-277. https://doi.org/10.1016/j.palaeo.2005.06.005

Chen, C.A. (1996). The Kuroshio intermediate water is the major source of nutrients on the East China Sea continental shelf. Oceanologica Acta, 19, 523-527.

Cheng, H., Edwards, R.L., Sinha, A., Spotl, C., Yi, L., Chen, S., et al., (2016). The Asian Monsoon over the past 640,000 years and ice age terminations. Nature, 534, 640646.

Clark, P.U., Archer, D., Pollard, D., Blum, J.D., Rial, J.A., Brovkin, V., et al. (2006). The Middle Pleistocene Transition: Characteristics, mechanisms, and implications for long-term changes in atmospheric $\mathrm{pCO}_{2}$. Quaternary Science Reviews, 25, 31503184. https://doi.org/10.1016/j.quascirev.2006.07.008

Clemens, S.C., Houlbourn, A., Kubota, Y., Lee, K.E., Liu, Z., Chen, G., et al. (2018). Precession-band variance missing from East Asian Monsoon runoff. Nature Communications, 9. DOI: 10.1038/s41467-018-05814-0

Clemens, S.C. \& Prell, W.L. (2003). A 350,000-year summer-monsoon multi-proxy stack from the Owen Ridge, Northern Arabian Sea. Marine Geology, 201, 35-51. https://doi.org/10.1016/S0025-3227(03)00207-X

Clemens, S.C. \& Prell, W.L. (2007). The timing of orbital-scale Indian Monsoon changes. Quaternary Science Reviews, 26, 275-278. https://doi.org/10.1016/j.quascirev.2006.11.010

Clemens, S.C., Murray, D.W., \& Prell, W.L. (1996). Nonstationary phase of the PlioPleistocene Asian Monsoon. Science, 274(5289), 943-948. https://doi.org/10.1126/science.274.5289.943 
Clemens, S.C., Prell, W.L., \& Sun, Y. (2010). Orbital-scale timing and mechanisms driving Late Pleistocene Indo-Asian summer monsoons: Reinterpreting cave speleothem $\delta^{18} \mathrm{O}$. Paleoceanography, 25(4), 1-19. https://doi.org/10.1029/2010PA001926

Coplen, T.B. (2011). Guidelines and recommended terms for expression of stableisotope-ratio and gas-ratio measurement results. Rapid Communications in Mass Spectrometry, 25(17), 2538-2560.

Crundwell, M., Scott, G., Naish, T., \& Carter, L. (2008). Glacial-interglacial ocean climate variability from planktonic foraminifera during the Mid-Pleistocene transition in the temperate Southwest Pacific, ODP Site 1123. Palaeogeography, Palaeoclimatology, Palaeoecology, 260, 202-229. https://doi.org/10.1016/j.palaeo.2007.08.023

Crusius, J., Pederson, T.F., \& Calvert, S.E. (1999). A 36 kyr geochemical record from the Sea of Japan of organic matter flux variations and changes in intermediate water oxygen concentrations. Paleoceanography, 14(2), 248-259.

Cruz, F.W., Burns, S.J., Karmann, I., Sharp, W.D., Vuille, M., Cardoso, A.O., et al. $(2005)$. Insolation-driven changes in atmospheric circulation over the past 116,000 years in subtropical Brazil. Nature, 434, 63-66. https://doi.org/10.1038/nature03365

Dwyer, G.S., Cronin, T.M., Baker, P.A., Raymo, M.E., Buzas, J.S., \& Correge, T. (1995). North Atlantic deepwater temperature change during Late Pliocene and Late Quaternary climatic cycles. Science, 270(5240), 1347-1351 . https://doi.org/10.1126/science.270.5240.1347

Emerson, S. \& Hedges, J.I. (1988). Processes controlling the organic carbon content of open-ocean sediments. Paleoceanography, 3(5), 621-634. https://doi.org/10.1029/PA003i005p00621

Ferrell, J.W. \& Prell, W.L. (1989). Climatic change and $\mathrm{CaCO}_{3}$ preservation: An 800,000 year bathymetric reconstruction from the central equatorial Pacific Ocean. Paleoceanography, 4(4), 447-466.

Fry, B. \& Sherr, E.B. (1984). ${ }^{13} \mathrm{C}$ measurements as indicators of carbon flow in marine and freshwater ecosystems. Contributions in Marine Science, 27, 13-47. DOI: 10.1007/978-1-4612-3498-2_12

Gamo, T. (2011). Dissolved oxygen in the bottom water of the Sea of Japan as a sensitive alarm for global climate change. TrAC - Trends in Analytical Chemistry, 30(8), 1308-1319. https://doi.org/10.1016/j.trac.2011.06.005 
Gamo, T. \& Horibe, Y. (1983). Abyssal circulation in the Japan Sea. Journal of the Oceanographical Society of Japan, 39(5), 220-230.

https://doi.org/10.1007/BF02070392

Ghil, M., Allen, M.R., Dettinger, M.D., Ide, K., Kondrashov, D., Mann, M.E., et al. (2002). Advanced spectral methods for climatic time series. Reviews of Geophysics, 40(1), 31-41. https://doi.org/10.1029/2000RG000092

Guo, Z.T., Biscaye, P., Wei, L.Y., Chen, X.H., Peng, S.Z., \& Liu, T. S. (2000). Monsoon variations over the last $1.2 \mathrm{Ma}$ from the weathering of loess-soil sequences in China. Geophysical Research Letters, 27, 1751-1754.

Guo, Q.Y. (1983). The strength index East Asian Summer Monsoon and its variation. Chinese Journal of Geography, 38, 207-217.

Hase, H., Yoon, J.H., \& Koterayama, W. (1999). The current structure of the Tsushima Warm Current along the Japanese coast. Journal of Oceanography, 55(2), 217235. https://doi.org/10.1023/A:1007894030095

Hays, J.D., Imbrie, J., \& Shackleton, N.J. (1976). Variations in the earth's orbit: Pacemaker of the ice ages. Science, 194(4270), 1121-1132. https://doi.org/10.1126/science.194.4270.1121

Hayes, J.M. (1982). Fractionation et al.: An introduction to isotopic measurements and terminology. Spectra, 8, 3-8.

Head, M.J. \& Gibbard, P.L. (2015). Early-Middle Pleistocene transitions: Linking terrestrial and marine realms. Quaternary International, 389, 7-46. https://doi.org/10.1016/j.quaint.2015.09.042

Heslop, D., Dekkers, M.J., \& Langereis, C.G. (2002). Timing and structure of the MidPleistocene Transition: Records from the loess deposits of northern China. Palaeogeography, Palaeoclimatology, Palaeoecology, 185, 133-143. https://doi.org/10.1016/S0031-0182(02)00282-1

Imbrie, J., Hays, J.D., Martinson, D.G., McIntyre, A., Mix, A.C., Morley, J.J., et al. J. (1984). The orbital theory of Pleistocene climate: Support from a revised chronology of the marine $\delta^{18} \mathrm{O}$ record. Milankovitch and Climate (Part 1). Reidel Publishing Company: Dordrecht.

Irino, T. \& Tada, R. (2000). Quantification of aeolian dust (Kosa) contribution to the Japan Sea sediments and its variation during the last $200 \mathrm{ky}$. Geochemical Journal, 34, 59-93. 
Irino, T., Tada, R., Ikehara, K., Sagawa, T., Karasuda, A., Kurokawa, S., et al. (2018). Construction of perfectly continuous records of physical properties for dark-light sediment sequences collected from the Japan Sea during Integrated Ocean Drilling Program Expedition 346 and their potential utilities as paleoceanographic studies. Progress in Earth and Planetary Science, 5(23). https://doi.org/https://doi.org/10.1186/s40645-018-0176-7

Isobe, A. (1998). On the origin of the Tsushima Warm Current and its seasonality. Continental Shelf Research, 19(1), 117-133. https://doi.org/10.1016/S02784343(98)00065-X

Isobe, A., Ando, M., Watanabe, T., Senjyu, T., Sugihara, S., \& Manda, A. (2002). Freshwater and temperature transports through the Tsushima-Korea Straits. Journal of Geophysical Research, 107, 3065. https://doi.org/10.1029/2000JC000702

Itaki, T. (2016). Transitional changes in microfossil assemblages in the Japan Sea from the Late Pliocene to Early Pleistocene related to global climatic and local tectonic events. Progress in Earth and Planetary Science, 3(1), 11. https://doi.org/10.1186/s40645-016-0087-4

Kawamura, H. \& Wu, P. (1998). Formation mechanism of Japan Sea Proper Water in the flux center off Vladivostok. JGR Oceans, 103(C10), 21611-21622. https://doi.org/10.1029/98JC01948

Khim, B.K., Bahk, J.J., Hyun, S., \& Lee, G.H. (2007). Late Pleistocene dark laminated mud layers from the Korea Plateau, western East Sea/Japan Sea, and their paleoceanographic implications. Palaeogeography, Palaeoclimatology, Palaeoecology, 247, 74-87.

Khim, B.K., Park, Y.H., Bahk, J.J., Jin, J.H., \& Lee, G.H. (2008). Spatial and temporal variation of geochemical properties and paleoceanographic implications in the South Korea Plateau (East Sea) during the late Quaternary. Quaternary International, 176, 46-61. https://doi.org/10.1016/j.quaint.2007.04.004

Kim, C.H. \& Yoon, J.H. (1999). A numerical modeling of the upper and the intermediate layer circulation in the East Sea. Journal of Oceanography, 55(2) 327-345. https://doi.org/10.1023/A:1007837212219

Kitaba, I., Harada, M., Hyodo, M., Katoh, S., Sato, H., \& Matsushita, M. (2011). MIS 21 and the Mid-Plesitocene climate transition: Climate and sea-level variation from a sediment core in Osaka Bay, Japan. Palaeogeography, Palaeoclimatology, Palaeoecology, 299, 227-239. https://doi.org/10.1016/j.palaeo.2010.11.004 
Kitamura, A. \& Kawagoe, T. (2006). Eustatic sea-level change at the Mid-Pleistocene climate transition: new evidence from the shallow-marine sediment record of Japan. Quaternary Science Reviews, 25, 323-335.

DOI: $10.1016 /$ j.quascirev.2005.02.009

Kitazato, H. (1984). Japan Sea since the last glacial age: Change of CCD-mainly based on analysis of core KH-79-3, C-3. Chikyu (Monthly, the Earth), 6, 567-570.

Kutzbach, J.E. (1981). Monsoon climate of the early Holocene: Climate experiment with the earth's orbital parameters for 9000 years ago. Science, 214(4516), 59-61. https://doi.org/10.1126/science.214.4516.59

Lee Chen, Y.L., Lu, H.B., Shiah, F.K., Gong, G.C., Liu, K.K., Kanda, J. (1999). New production and F-ratio on the continental shelf of the East China Sea: Comparisons between nitrate inputs from the subsurface Kuroshio Current and the Changjiang River. Estuarine, Coastal and Shelf Science, 48(1), 59-75.

Lee, K.E., Bahk, J.J., \& Narita, H. (2003). Temporal variations in productivity and planktonic ecological structure in the East Sea (Japan Sea) since the last glaciation. Geo-Marine Letters, 23(2), 125-129. https://doi.org/10.1007/s00367003-0132-3

Li, T., Liu, F., Abels, H.A., You, C.F., Zhang, Z., Chen, J., et al. (2017). Continued obliquity pacing of East Asian summer precipitation after the mid-Pleistocene transition. Earth and Planetary Science Letters, 457, 181-190. https://doi.org/10.1016/j.epsl.2016.09.045

Li, Q., Wang, P., Zhao, Q., Tian, J., Cheng, X., Jian, Z., et al. (2008). Paleoceanography of the mid-Pleistocene South China Sea. Quaternary Science Reviews, 27, 12171233. https://doi.org/10.1016/j.quascirev.2008.02.007

Lisiecki, L.E. \& Raymo, M.E. (2005). A Pliocene-Pleistocene stack of 57 globally distributed benthic $\delta^{18} \mathrm{O}$ records. Paleoceanography, 20(1), 1-17. https://doi.org/10.1029/2004PA001071

Lu, F., Ma, C., Zhu, C., Lu, H., Zhang, X, Huang, K., et al. (2018). Variability of East Asian summer monsoon precipitation during the Holocene and possible forcing mechanisms. Climate Dynamics. https://doi.org/10.1007/s00382-018-4175-6

Lu, H., Miao, X., Zhou, Y., Mason, J., Swinheart, J., Zhang, J., et al. (2005). Late Quaternary aeolian activity in the Mu Us and Otindag dune fields (north China) and lagged response to insolation forcing. Geophysical Research Letters, 32, 1-4. https://doi.org/10.1029/2005GL024560 
Mann, M.E. \& Lees, J.M. (1996). Robust estimation of background noise and signal detection in climatic time series. Climatic Change, 33, 409-445.

https://doi.org/10.1007/BF00142586

McKinney, C.R., McCrea, J.M., Epstein, S., Allen, H.A., \& Urey, H.C. (1950). Improvements in mass spectrometers for the measurement of small differences in isotope abundance ratios. Review of Scientific Intrustments, 21(724). https://doi.org/10.1063/1.1745698

Medina-Elizalde, M. \& Lea, D.W. (2005). The Mid-Pleistocene Transition in the tropical Pacific. Science, 310(5750), 1009-1012. https://doi.org/10.1126/science.1115933

Müller, P J. \& Suess, E. (1979). Productivity, sedimentation rate, and sedimentary organic matter in the oceans- I. Organic carbon preservation. Deep Sea Research Part A, Oceanographic Research Papers, 26(12), 1347-1362. https://doi.org/10.1016/0198-0149(79)90003-7

Nakagawa, T., Okuda, M., Yonenobu, H., Miyoshi, N., Fujiki, T., Gotanda, K., et al. (2008). Regulation of the monsoon climate by two different orbital rhythms and forcing mechanisms. Geology, 36(6), 491-494. https://doi.org/10.1130/G24586A.1

Oba, T., Kato, M., Kitazato, H., Koizumi, I., Omura, A., Sakai, T., et al. (1991). Paleoenvironmental changes in the Japan Sea during the last 85,000 years. Paleoceanography, 6(4), 499-518.

O’Leary, M.H. (1981). Carbon isotope fractionation in plants. Phytochemistry, 20, 553567. https://doi.org/10.1016/0031-9422(81)85134-5

Peterson, B.J. \& Fry, B. (1987). Stable isotopes in ecosystem studies. Annual Review of Ecology and Systematics, 18, 293-320.

Rossignol-Strick, M., Paterne, M., Bassinot, F.C., Emeis, K.C., \& De Lange, G.J. (1998). An unusual Mid-Pleistocene monsoon period over Africa and Asia. Nature, 392, 269-272. https://doi.org/10.1038/32631

Ruddiman, W.F. (2006). What is the timing of orbital-scale monsoon changes? Quaternary Science Reviews, 25, 657-658. https://doi.org/10.1016/j.quascirev.2006.02.004

Sagawa, T., Nagahashi, Y., Satoguchi, Y., Holbourn, A., Itaki, T., Gallagher, S.J., et al. (2018). Integrated tephrostratigraphy and stable isotope stratigraphy in the Japan Sea and East China Sea using IODP Sites U1426, U1427 and U1429, Expedition 346 Asian Monsoon. Progress in Earth and Planetary Science, 5(18). 
Satoguchi, Y. \& Nagahashi, Y. (2012). Tephrostratigraphy of the Pliocene to Middle Pleistocene Series in Honshu and Kyushu Islands, Japan. Island Arc, 21(3), 149169. https://doi.org/10.1111/j.1440-1738.2012.00816.x

Shackleton, N.J. \& Opdyke, N.D. (1976). Oxygen-isotope and paleomagnetic stratigraphy of Pacific core V28-239: Late Pliocene to latest Pleistocene. Geological Society of America Memoir, 145, 449-464.

Shigemitsu, M., Watanabe, Y.W., \& Narita, H. (2009). Sedimentary inorganic nitrogen and its isotope ratio in the Western Subarctic Pacific over the last 145 kyr. Journal of Oceanography, 65, 541-548.

Sun, Y., Kutzbach, J., An, Z., Clemens, S., Liu, Z., Liu, W., et al. (2015). Astronomical and glacial forcing of East Asian Summer Monsoon variability. Quaternary Science Reviews, 115, 132-142. https://doi.org/10.1016/j.quascirev.2015.03.009

Sun, Y., Clemens, S.C., An, Z., \& Yu, Z. (2006). Astronomical timescale and palaeoclimatic implication of stacked 3.6-Myr monsoon records from the Chinese Loess Plateau. Quaternary Science Reviews, 25, 33-48. https://doi.org/10.1016/j.quascirev.2005.07.005

Tada, R., Irino, T., \& Koizumi, I. (1999). Land-ocean linkages over orbital and millennial timescales recorded in Late Quaternary sediments of the Japan Sea. Paleoceanography, 14(2), 236-247.

Tada, R., Koizumi, I., Cramp, A., \& Rahman, A. (1992). Correlation of dark and light layers, and the origin of their cyclicity in the Quaternary sediments from the Japan Sea. Proceedings of the Ocean Drilling Program Scientific Results, 127, 577-601.

Tada, R., Murray, R.W., Alvarez Zarikian, C.A., Anderson, W.T., Bract, B.J., et al. (2015). Expedition 346 Summary. Proceedings of the Ocean Drilling Program, 346.

Tada, R. (1994). Paleoceanographic evolution of the Japan Sea. Palaeogeography, Palaeoclimatology, Palaeoecology, 108(3-4), 487-508. https://doi.org/10.1016/0031-0182(94)90248-8

Tada, R. (2004). Onset and evolution of millennial-scale variability in the Asian Monsoon and its impact on paleoceanography of the Japan Sea. Geophysical Monograph Series, 149, 283-298. https://doi.org/10.1029/149GM15 
Tada, R., Irino, T., Ikehara, K., Karasuda, A., Sugisaki, S., Xuan, C., et al. (2018). Highresolution and high-precision correlation of dark and light layers in the Quaternary hemipelagic sediments of the Japan Sea recovered during IODP Expedition 346. Progress in Earth and Planetary Science, 5(19). https://doi.org/10.1186/s40645-018-0167-8

Takikawa, T. \& Yoon, J.H. (2005). Volume transport through the Tsushima Straits estimated from sea level difference. Journal of Oceanography, 61(4), 699-708. https://doi.org/10.1007/s10872-005-0077-4

Thomas, E.K., Clemens, S.C., Sun, Y., Prell, W.L., Huang, Y., Gao, L., et al. (2016). Heterodynes dominate precipitation isotopes in the East Asian Monsoon region, reflecting interaction of multiple climate factors. Earth and Planetary Science Letters, 455, 196-206. https://doi.org/10.1016/j.eps1.2016.09.044

Thomson, D.J. (1982). Spectrum estimation and harmonic analysis. Proceedings of the IEEE, 70(9), 1055-1096. https://doi.org/10.1109/PROC.1982.12433

Tiedemann, R., Sarnthein, M., \& Shackleton, N.J. (1994). Astronomic timescale for the Pliocene Atlantic $\delta^{18} \mathrm{O}$ and dust flux records of Ocean Drilling Program Site 659. Paleoceanography, 9(4), 619-638. https://doi.org/10.1029/94PA00208

Torrence, C. \& Compo, G.P. (1998). A practical guide to wavelet analysis. Bulletin of the American Meteorological Society, 79(1), 61-78. https://doi.org/10.1175/15200477(1998)079<0061:APGTWA>2.0.CO;2

Usami, K., Ohi, T., Hasegawa, S., \& Ikehara, K. (2013). Foraminiferal records of bottomwater oxygenation and surface-water productivity in the southern Japan Sea during 160-15ka: Associations with insolation changes. Marine Micropaleontology, 101, 10-27. https://doi.org/10.1016/j.marmicro.2013.03.006

Wang, B., Wu, R., \& Lau, K.-M. (2001). Interannual variability of the Asian Summer Monsoon: Contrasts between the Indian and Western North Pacific-East Asian Monsoons. American Meterological Society, 14, 4073-4090.

Wang, P. (1999). Response of Western Pacific marginal seas to glacial cycles: Paleoceanographic and sedimentological features. Marine Geology, 156(1-4), 539. https://doi.org/10.1016/S0025-3227(98)00172-8

Wang, P., Clemens, S.C., Beaufort, L., Braconnot, P., Ganssen, G., Jian, Z., et al. (2005). Evolution and variability of the Asian Monsoon system: State of the art and outstanding issues. Quaternary Science Reviews, 24, 595-629. https://doi.org/10.1016/j.quascirev.2004.10.002 
Wang, Y., Cheng, H., Edwards, R. L., Kong, X., Shao, X., Chen, S., et al. (2008). Millennial- and orbital-scale changes in the East Asian Monsoon over the past 224,000 years. Nature, 451, 1090-1093. https://doi.org/10.1038/nature06692

Watanabe, S., Tada, R., \& Ikehara, K. (2007). Sediment fabrics, oxygenation history, and circulation modes of Japan Sea during the Late Quaternary. Palaeogeography, Palaeoclimatology, Palaeoecology, 247, 50-64.

Watanabe, T., Katoh, O., \& Yamada, H. (2006). Structure of the Tsushima Warm Current in the northeastern Japan Sea. Journal of Oceanography, 62(4), 527-538. https://doi.org/10.1007/s10872-006-0073-3

Weber, M.E., Lantzsch, H., Dekens, P., Das, S.K., Reilly, B.T., Martos, Y.M., et al. (2018). 200,000 years of monsoonal history recorded on the lower Bengal Fan strong response to insolation forcing. Global and Planetary Change, 166, 107119. https://doi.org/10.1016/j.gloplacha.2018.04.003

Williams, D.F., Peck, J., Karabanov, E.B., Prokopenko, A.A., Kravchinsky, V., King, J., et al. (1997). Lake Baikal record of continental climate response to orbital insolation during the past 5 million years. Science, 278(5340), 1114-1117. https://doi.org/10.1126/science.278.5340.1114

Yuan, D., Cheng, H., Edwards, R.L., Dykoski, C.A., Kelly, M.J., Zhang, M., et al. (2004). Timing, duration, and transitions of the last interglacial Asian Monsoon. Science, 304(5670), 575-578. https://doi.org/10.1126/science.1091220

Zhang, W., De Vleeschouwer, D., Shen, J., Zhang, Z., \& Zeng, L. (2018). Orbital time scale records of Asian eolian dust from the Sea of Japan since the early Pliocene. Quaternary Science Reviews, 187, 157-167. https://doi.org/10.1016/j.quascirev.2018.03.004 


\section{CHAPTER 4: REDUCED UPWELLING OF THE KUROSHIO CURRENT DURING STADIAL EVENTS IN MIS 5 AND MIS $7^{8}$}

\subsection{Abstract}

Glacio-eustatic sea level changes have a significant impact on the marginal East China Sea. During glacial periods, significant portions of the epicontinental shelf were exposed, leading to the migration of the Yangtze and Yellow Rivers thousands of kilometers across the shelf and discharge near the Okinawa Trough. The migration of these two large river systems would therefore increase the deposition of terrestrial material during glacial periods. Elemental and stable isotopic analyses of carbon and nitrogen, however, indicate no significant differentiation between glacial and interglacial conditions within the East China Sea during the past 350,000 years. Instead, a relatively stable record of paleoproductivity exists due to continuous presence of the Kuroshio Current in the Okinawa Trough with the exception abrupt, negative excursions during stadial events Marine Isotope Stage (MIS) 5.2, MIS 5.4, MIS 7.2, and MIS 7.4. Continuous influx of the Kuroshio Current into the East China Sea, in addition to the increased intensity of EASM conditions during interglacials and EAWM conditions during glacials, allowed for continuous upwelling, resulting in elevated rates of primary productivity occurring within the surface waters. However, during stadial events, the limited Kuroshio Current influx and the resulting reduction in upwelling of the Kuroshio Intermediate Water within the East China Sea severely reduced the net primary

\footnotetext{
${ }^{8}$ To be submitted to Paleoceanography and Paleoclimatology. Black, H.D., Anderson, W.T., Anderson, C.H., and Murray, R.W.
} 
productivity. Potential gravity flow layers, such as turbidites, are also found within the stadial events, corroborating a likely decrease in Kuroshio flux and increased terrestrial material deposited at Site U1429.

\subsection{Introduction}

The East Asian Monsoon (EAM) is a significant component of the earth's climate system that influences the societal and economic activity of approximately one-third of the world's population in southeast Asia and China. The EAM is comprised of two subsystems, the East Asian Summer Monsoon (EASM) and the East Asian Winter Monsoon (EAWM), both of which are controlled by temperature and air pressure gradients resulting from differential heating of land and sea (Wang et al., 2005). The EASM is typically associated with warmer, wetter conditions with increased precipitation while the EAWM is associated with colder, dryer conditions and increased wind intensity and eolian flux (Guo, 1983; Weber et al., 2018; Zhang et al., 2018). Differences between EASM and EAWM conditions within the East China Sea (ECS) between glacial and interglacial periods should lead to different paleoceanographic conditions within the sea. Changes in flux of oceanic currents, such as the Kuroshio Current, and contribution of terrestrial organic matter from the Yangtze and Yellow Rivers should lead to distinct variations in surface productivity between glacial and interglacial periods as glacioeustatic sea levels vary throughout recent geological history.

The ECS is a shallow, marginal sea with an area greater than $770,000 \mathrm{~km}^{2}$ (Kawahata et al., 2006). It is located between China, Taiwan, Korea, and the Japanese archipelago. The ECS is separated from the South China Sea by the Taiwan Strait and 
East Taiwan Strait, Japan Sea from the Tsushima Strait (also known as the Korean Strait; Ichikawa \& Beardsley, 2002), North Pacific Ocean by the Tokara Straight, and an open exchange with the Yellow and Bohai Seas (Wong et al., 2000)(Figure 4.1). The two main features of the ECS are the shallow $(<200 \mathrm{~m})$ epicontinental shelf and the deep $(>2000$ m) Okinawa Trough located northwest of the Ryukyu Island chain (Wong et al., 2000). The northern portion of the Okinawa Trough is significantly shallower $(<1000 \mathrm{~m})$ than the middle and southern portions (Ichikawa \& Beardsley, 2002).

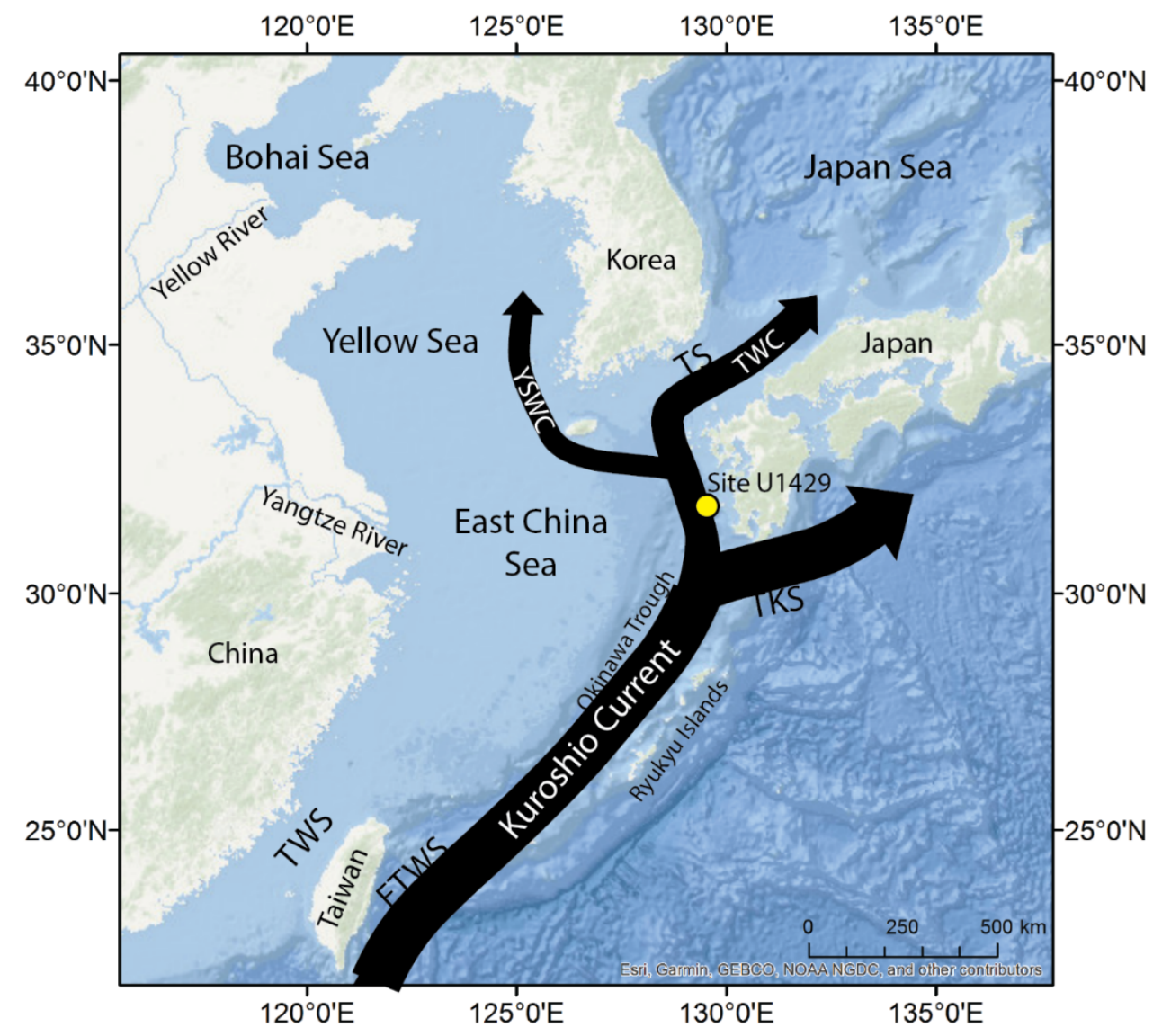

Figure 4.1. Map of the East China Sea and surrounding land and water bodies. TWC=Tsushima Warm Current; YSWC=Yellow Sea Warm Current; TS=Tsushima Strait; TKS=Tokara Strait; TWS=Taiwan Strait; ETWS=East Taiwan Strait. (Modified from Kawahata et al., 2006.) 
Two large watersheds are presently discharged indirectly into the ECS through the Yangtze (Changjiang) River and Yellow (Huanghe) River systems in mainland China. The Yangtze River discharges into the Yellow Sea while the Yellow River is discharged $\sim 850 \mathrm{~km}$ farther north into the Bohai Sea and later mixes with the Yangtze and other Chinese tributaries as the China Coastal Water (CCW)(Wong et al., 2000). The combined transport of these two rivers release $1.6 \times 10^{9}$ tons of sediment annually, which is $\sim 10 \%$ of the total world sediment discharge (Saito et al., 2001). The Yangtze River has one of the world's largest drainage basins with an area greater than 1.8 million $\mathrm{km}^{2}$ (Beny et al., 2018 ) and contributes more than $80-90 \%$ of all freshwater discharge into the ECS (Beardsley et al., 1985; Ichikawa \& Beardsley, 2002) with an annual discharge of 9.28 $\mathrm{x} 10^{11} \mathrm{~m}^{3} \mathrm{yr}^{-1}$. The Yellow River has a smaller drainage basin of $750,000 \mathrm{~km}^{2}$ (Beny et al., 2018 ) and significantly lower discharge of $0.41 \times 10^{11} \mathrm{~m}^{3} \mathrm{yr}^{-1}$ in comparison. The sediment supply of the Yellow River, however, is an order of magnitude higher than the Yangtze River (Kawahata et al., 2006) and has the second highest sediment discharge found in the world (Saito et al., 2001).

The topographic features of these two river systems cause significant differences between their physical and chemical characteristics (Saito et al., 2001). The Yangtze River is located along the edge of the EAM impact area, which causes it to have significant seasonal variation in freshwater discharge with highest water fluxes during the summer when the EASM produces higher precipitation rates (Gallagher et al., 2015). The Yellow River is also located within the EASM impact area but is unique in that it flows through the Chinese Loess Plateau (CLP) where numerous speleothem studies have identified changes within the EAM during the Pleistocene (Cheng et al., 2009; Wang et 
al., 2005; Wang et al., 2008; Yuan et al., 2004). At present, $~ 90 \%$ of sediment transported by the Yellow River originated in the CLP (Ren \& Shi, 1991).

A complex oceanic current relationship exists within the ECS. The most significant current, the Kuroshio Current, begins east of the Philippines and enters the ECS through the East Taiwan Strait and flows along the ECS continental shelf along the Okinawa Trough (Kawahata et al., 2006; Zhao et al., 2017, 2018). South of Japan's Kyushu Island, the Kuroshio Current branches into three segments. The first and largest segment, the Kuroshio Extension, flows eastwardly out of through the Tokara Straight into the Pacific; the second segment mixes with the ECSCW and flows through the Tsushima Strait into the Japan Sea as the Tsushima Warm Current; the third segment moves northwestwardly into the Yellow Sea as the Yellow Sea Warm Current (Gallagher et al., 2015). Other contributing currents include the Taiwan Warm Current that flows northeastwardly through the Taiwan Strait into the ECS (Diekmann et al., 2008) and the Yellow Sea Coastal Current, which flows southeastwardly from the mouth of the Yellow River along the coast of mainland China, where it mixes with Yangtze River discharge before becoming the CCW (Chen et al., 2004).

Water along the continental ECS shelf is predominately $(\sim 90 \%)$ from the Kuroshio Current (Chen et al., 1996), with Kuroshio surface water contributing over 60\% of the total water flux (Chen et al., 1995). In general, the Kuroshio Current is very low in nutrients $\left(\mathrm{NO}_{3}<0.1 \mu \mathrm{mol} \mathrm{kg}{ }^{-1} ; \mathrm{PO}_{4}<0.02 \mu \mathrm{mol} \mathrm{kg}{ }^{-1} ; \mathrm{SiO}_{2}<1 \mu \mathrm{mol} \mathrm{kg}{ }^{-1}\right)$, but the subsurface Kuroshio Intermediate Water contains significantly higher nutrient loads $\left(\mathrm{NO}_{3}\right.$ $\left.\sim 25 \mu \mathrm{mol} \mathrm{kg}{ }^{-1} ; \mathrm{PO}_{4} \sim 1.7 \mu \mathrm{mol} \mathrm{kg}^{-1} ; \mathrm{SiO}_{2} \sim 60 \mu \mathrm{mol} \mathrm{kg}^{-1}\right)($ Chen et al., 2004) and therefore contributes the most to the nutrient fluxes within the ECS (Chen et al., 1996). Most of the 
nutrient flux within the ECS originates from the subsurface Kuroshio Intermediate Water that is upwelled along the edge of the continental slope during the summer (Chen, 1996; Chang et al., 2009), which is caused by increased flux from the Taiwan Warm Current, CCW, and fluvial discharge from the Yangtze and Yellow Rivers (Chen et al., 2004). Glacial/interglacial cycles have had a significant impact on the ECS as a result of its shallow nature as an epicontinental shelf, especially as a river-dominated ocean margin (Liu et al., 2007). During periods of glacio-eustatic sea level reductions, such as in the Last Glacial Maximum (LGM) when sea levels decreased $\sim 130 \mathrm{~m}$, over one-half of the ECS continental shelf is exposed and both the Yangtze and Yellow Rivers migrate thousands of kilometers farther south (Figure 4.2)(Uehara et al., 2002; Gallagher et al., 2015). Depending on the location within the Okinawa Trough of the ECS, relative contributions from Yangtze and Yellow River discharge vary during glacial periods (Waelbroeck et al., 2002). Within the northern portion of the Okinawa Trough, the mouth of the Yellow River migrated near Korea's Cheju Island and directly fed into the Danjo Basin (Oiwane et al., 2011; Xu et al., 2014) while the middle and southern portions of the Okinawa Trough were affected by Yangtze River discharge (Jian et al., 2000; Ujiié \& Ujiié, 1999; Ujiié et al., 2003). During interglacial periods, the CCW expanded as a result of increased discharge from the Yangtze River as a result of increased EASM precipitation (Gallagher et al., 2015) 


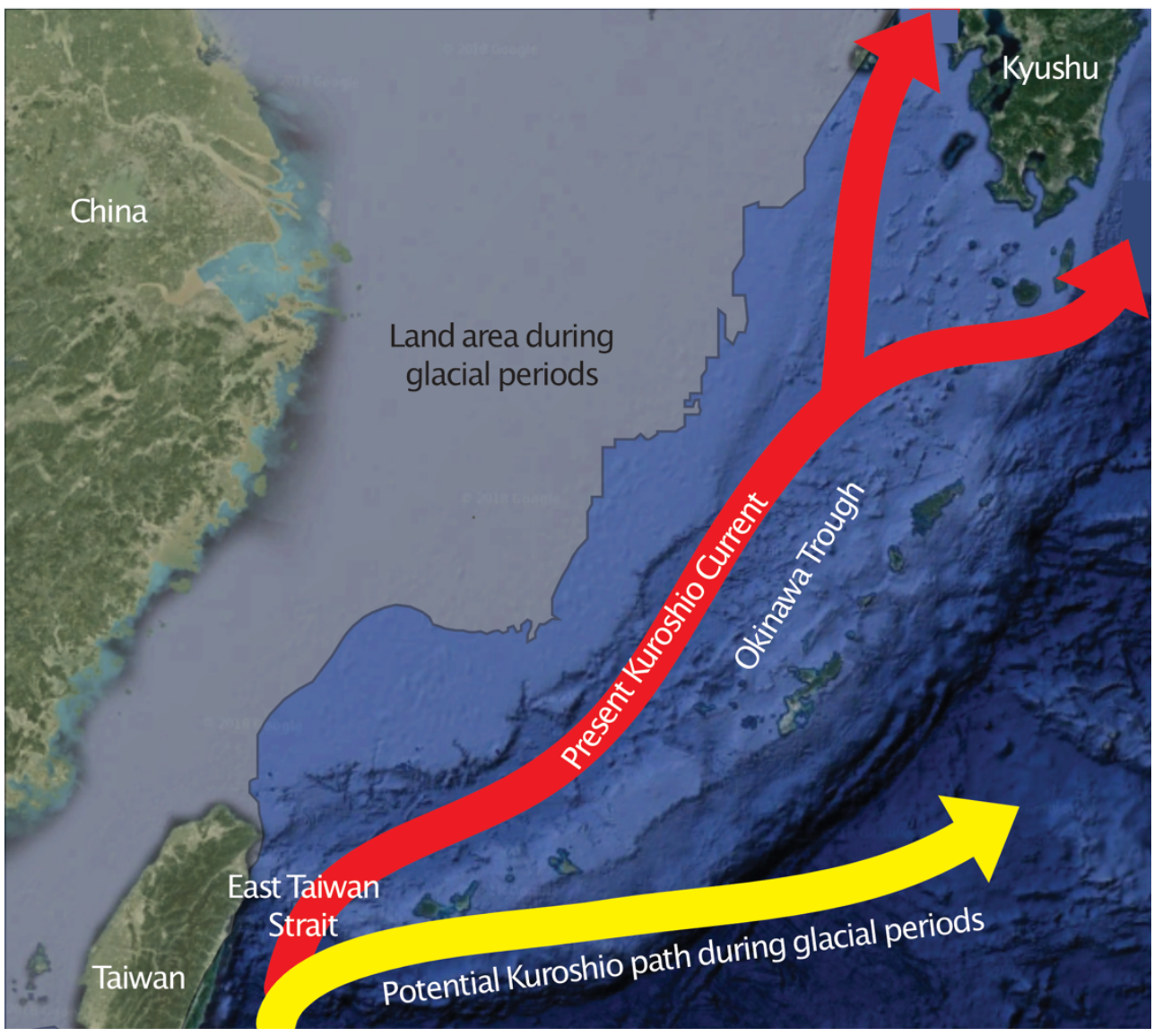

Figure 4.2. The relative location of the Kuroshio Current at present, the extent of the East China Sea shelf during glacial periods, and the potential deflected path during glacial periods. (Modified from Gallagher et al., 2015).

There is currently extensive scientific debate on the effect of glacial low stands on the potential migration of the Kuroshio Current path. Some have argued that the Kuroshio Current shifts eastward from the Yonaguni Depression and does not enter through the East Taiwan Strait at all as a result of the emergence of a land bridge between the East Taiwan Strait and the Ryukyu Arc (Ujiie et al., 1991; Ahagon et al., 1993). Instead of entering the ECS, the Kuroshio Current allegedly flows along the eastward edge of the Ryukyu Arc to the Pacific (Ujiié et al., 2003). However, other studies have argued that the Kuroshio Current does migrate during glacial low stands, but typically 
only $3^{\circ}$ West, which still allowed it to flow through the East Taiwan Strait into the ECS, and ultimately through the Okinawa Trough (Dou et al., 2010; Gallagher et al., 2015). Although the exact location of the Kuroshio Current within the ECS during glacial periods is still debated, the current only has significant impacts on the entire ECS shelf during interglacial periods and little to no impact during glacial low stands (Diekmann et al., 2008; Jian et al., 2000). During low stands, only the outer portion of the Tsushima Strait and Okinawa Trough are submerged as a result of decreased glacio-eustatic sea levels (Lim et al., 2006; Park et al., 2000). Deeper portions of the ECS, such as the Okinawa Trough, however, are deep enough to allow the Kuroshio Current to flow continuously during glacial periods regardless of sea level (Ichikawa \& Beardsley, 2002; Wong et al., 2000). Study locations within the Okinawa Trough would, therefore, be an ideal location to better understand the influence of the Kuroshio Current throughout both interglacial and glacial periods.

This study aimed to reconstruct temporal variations in relative paleoproductivity levels in the Okinawa Trough of the ECS at Integrated Ocean Drilling Program (IODP) Expedition 346 Site U1429 through the use of carbon and nitrogen elemental and isotopic analyses of preserved sedimentary organic matter. Significant variation between ocean current positions and intensities as well as the proximity and discharge of river deltas during glacial and interglacial periods should yield new information on the impact of the EAM system within the marginal sea and how fluctuations within the monsoonal system affected primary productivity within the surface waters of the sea. 


\subsection{Study Site}

IODP Site U1429 is located within the ECS at $31^{\circ} 37.04^{\prime} \mathrm{N}, 128^{\circ} 59.85^{\prime} \mathrm{E}$ and 732 meters below sea level (mbsl)(Tada et al., 2015). Site U1429 is located within the northern Okinawa Trough of the Danjo Basin and is situated under the second branch of the Kuroshio Current where it mixes with the ECSCW before flowing through the Tsushima Strait as the TWC (Tada et al., 2015). At present, Site U1429 is located 700 $\mathrm{km}$ from the Yangtze River mouth and 1,200 km from the Yellow River mouth (Anderson et al., 2018). During significant glacio-eustatic sea level decreases during glacial periods, however, these two rivers migrate farther south and Site U1429 is only approximately $400 \mathrm{~km}$ away from the Yangtze River mouth and $150 \mathrm{~km}$ from the Yellow River mouth (Uehara et al., 2002).

Three holes were cored at Site U1429 with over 570 m of sediment recovered that spans the Holocene to Middle Pleistocene ( $400 \mathrm{ka})$. This site consists of two major lithographic units, Unit A and B, with Unit A penetrating to about $179 \mathrm{~m}$ depth and Unit B terminated at $179 \mathrm{~m}$ to $188 \mathrm{~m}$ depth as a result of the presence of thick volcanic sands (Tada et al., 2015). Site U1429 has a high sedimentation rate $(\sim 48 \mathrm{~cm} / \mathrm{ky})($ Sagawa et al., $2018)$ and high concentrations of calcium carbonate $\left(<43 \% \mathrm{CaCO}_{3}\right)$. All samples used in this study are from Unit A, which has subtle color variability compared to other IODP Expedition 346 sites which have distinct alternation of light and dark colored sedimentary layers. The sediment is moderately to heavily bioturbated with a homogenous, structureless appearance and ranges in color from olive gray to light greenish gray (Tada et al., 2015) with 11 tephra layers present (Sagawa et al., 2018). The sediment primarily 
consists of nannofossil ooze and nannofossil rich clay with a high abundance of foraminifera and diatoms.

Shipboard observations determined that both color reflectance and $\% \mathrm{CaCO}_{3}$ generally exhibit glacial/interglacial variability where lighter sediment color typically had higher concentrations of $\mathrm{CaCO}_{3}$ (Tada et al., 2015). Sediments deposited during interglacial periods typically had higher $\mathrm{CaCO}_{3}$ concentrations than glacial sediments. At depths $>124 \mathrm{~m}(\sim 242 \mathrm{ka})$, the $\mathrm{CaCO}_{3}$ concentration greatly varies ( 0 to $\left.45 \%\right)$ as a result

of the presence of interbedded sand layers near the base of Unit A. With the exception of sand and tephra layers, the amount of total organic carbon (TOC) remains relatively stable $(0.1-2.9 \%$ TOC) throughout Site U1429, which may indicate better preservation as a result of the high sedimentation rate.

\subsection{Methods}

A total of 255 sedimentary samples from the upper $\sim 170 \mathrm{~m}$ of Site U1429 were analyzed at Florida International University’s Southeastern Environmental Research Center's Stable Isotope Laboratory (SERC-SIL). The samples were dried overnight in a $60^{\circ} \mathrm{C}$ oven, ground to a fine powder, and homogenized in a Spex $800 \mathrm{M}$ mixer/mill for 5 minutes. Samples analyzed for $\% \mathrm{TN}$ and $\delta^{15} \mathrm{~N}$ were analyzed as a bulk sample while $\%$ TOC and $\delta^{13} \mathrm{C}$ were decarbonated using a $10 \% \mathrm{HCl}$ solution where the acid bath was performed three times for $\sim 24$ hours followed by three deionized (DI) water baths for $\sim 24$ hours. Both bulk N ( $\sim 15 \mathrm{mg})$ and decarbonated $\mathrm{C}(\sim 5 \mathrm{mg})$ samples were analyzed in an NA 1500 EA coupled to a Thermo Delta C IRMS. Isotopic values are expressed in standard delta notation where 


$$
\delta \mathrm{R}=\left[\left(\mathrm{R}_{\text {sample }}-\mathrm{R}_{\text {standard }}\right) / \mathrm{R}_{\text {standard }}\right] * 1000
$$

and $\mathrm{R}_{\text {sample }}$ is the ratio of the heavy to light isotope in the sample and $\mathrm{R}_{\text {standard }}$ is the ratio of the heavy to light isotope in the standard (McKinney et al., 1950; Hayes, 1982; Coplen, 2011). All isotopic values are reported in parts per mil (\%o) vs. VPDB and AIR for carbon and nitrogen, respectively (Appendix 1). Precision $(1 \sigma)$ was better than \pm $0.08 \%$ for carbon and $\pm 0.14 \%$ for nitrogen. Thirty-two samples were analyzed in duplicate with a precision better than $\pm 0.09 \%$ and $\pm 0.28 \%$ for carbon and nitrogen, respectively.

The inorganic carbon concentration (\%TIC) was measured using a UIC CM140 coulometer. Fifteen mg of bulk sample was reacted with $10 \mathrm{~mL}$ of $10 \% \mathrm{HClO}_{4}$ until $\mathrm{CO}_{2}$ detection ceased. The calcium carbonate concentration $\left(\% \mathrm{CaCO}_{3}\right)$ was calculated by multiplying the $\% \mathrm{IC}$ by 8.33 under the assumption that all inorganic carbon is $\mathrm{CaCO}_{3}$ (Liu et al., 2014). Precision was determined using two standards: Fisher Scientific's pure carbonate standard and Nacalai Tesque's pure sodium carbonate standard. Precision $(1 \sigma)$ was better than $\pm 0.18 \%$. Forty-one samples were analyzed in duplicate with $\sigma$ better than $\pm 0.08 \%$.

Continuous sedimentary sequences for Site U1429 were created by the splicing technique using physical properties such as the lightness $\left(\mathrm{L}^{*}\right)$ and color of sediments, magnetic susceptibility, natural gamma-ray radiation (NGR), and gamma-ray attenuation density (GRA)(Irino et al., 2018)9 . Lightness (L*) values were recorded using color scanning imaging at a $5 \mathrm{~mm}$ resolution (Irino et al., 2018). A two-tailed t-Test for

\footnotetext{
${ }^{9}$ Data was collected onboard the Joides Resolution by Expedition 346 Scientists. See Tada (2015) for more details.
} 
uneven variances was used to determine if a significant statistical difference exists between glacial and interglacial time periods for each of the geochemical parameters $\left(\% \mathrm{CaCO}_{3}, \% \mathrm{TOC}, \delta^{13} \mathrm{C}, \% \mathrm{TN}\right.$, and $\left.\delta^{15} \mathrm{~N}\right)$. A two-tailed t-Test was used due to the symmetrical, normal distribution of the geochemical data that produced both positive and negative tails of the distribution (Boneau, 1960). To better understand the variability between the multiple independent geochemical datasets and reduce them to fewer variables (principal components), principal component analysis (PCA) was completed using JMP statistical software for all geochemical proxies studied $\left(\% \mathrm{CaCO}_{3}, \% \mathrm{TOC}\right.$, $\delta^{13} \mathrm{C}, \% \mathrm{TN}$, and $\delta^{15} \mathrm{~N}$ ) between the different Marine Isotope Stages (MIS 1 to MIS 10).

\subsection{Results}

Carbonate $\left(\mathrm{CaCO}_{3}\right)$ concentrations ranged from $0.7 \%$ to $42.8 \%$ with a mean of $18.2 \% \mathrm{CaCO}_{3}$. TOC contents ranged from $0.1 \%$ to $2.9 \%$ with an average of $1.6 \%$ while $\delta^{13} \mathrm{C}$ values are typical of mixed marine origin and ranged from $-24.7 \%$ to $-17.7 \%$ with an average of $-21.2 \%$. TN ranged from $0.0 \%$ to $0.2 \%$ with a mean of $0.1 \%$ while $\delta^{15} \mathrm{~N}$ values ranged from $1.2 \%$ to $13.4 \%$ with an average of $6.7 \%$ (Appendix 4 ). The standard deviation of $\% \mathrm{CaCO}_{3}(9.56 \%)$ was the highest out of all geochemical proxies studied, with the remaining four proxies' variance ranging from $0.5 \% \mathrm{TOC}, 1.3 \%{ }_{0} \delta^{13} \mathrm{C}, 0.0 \% \mathrm{TN}$, and $1.3 \% 0 \delta^{15} \mathrm{~N}$. Except for $\mathrm{CaCO}_{3}$, there was a general increase in concentration/enrichment of the geochemical proxies to the present (Figure 4.3). 


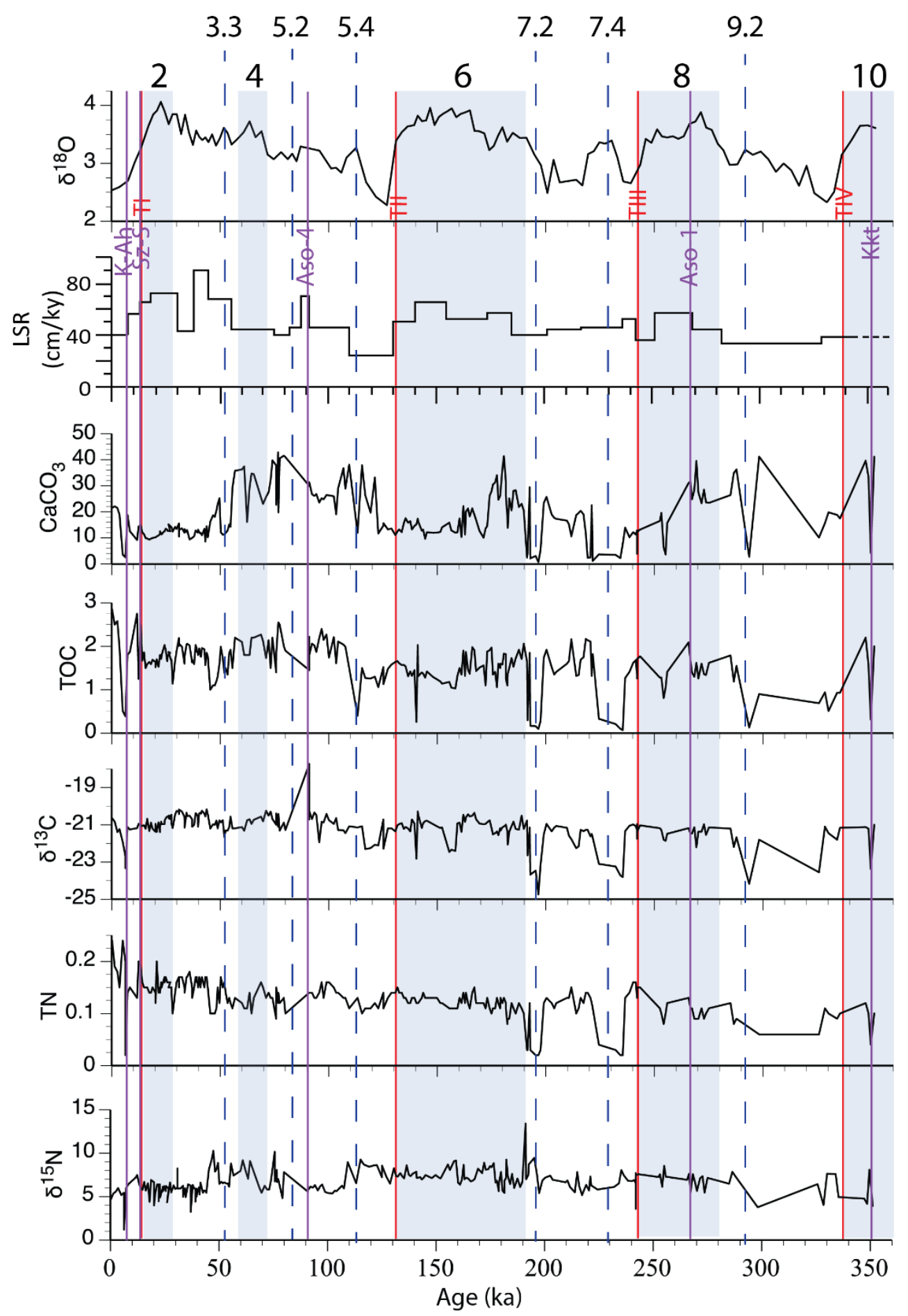

Figure 4.3. Benthic foraminifera $\delta^{18} \mathrm{O}$ (Sagawa et al., 2018), linear sedimentation rate (LSR; Sagawa et al., 2018), $\% \mathrm{CaCO}_{3}, \% \mathrm{TOC}, \delta^{13} \mathrm{C}, \% \mathrm{TN}$, and $\delta^{15} \mathrm{~N}$ values for Site U1429. Vertical blue lines indicate tephra layers (Sagawa et al., 2018), red lines indicate glacial terminations TI, TII, TIII, and TIV, and shaded gray areas are glacial marine isotope stages. Dashed blue lines indicate stadial events within the interglacial periods. 
A two-tailed t-test indicated that none of the geochemical proxy values were significantly different between glacial $(n=119)$ and interglacial $(n=135)$ periods $(p>0.05)$. PCA identified two significant principal components within the geochemical data, with PC1 containing $48.6 \%$ of the variance and PC2 containing $29.2 \%$ of the variance. PC1 is differentiated between the more recent MIS 1 to MIS 6 and older samples from MIS 7 to MIS 10. PC2 has a positive correlation with most glacial periods (MIS 4, MIS 6, MIS 8, and MIS 10) as well as the interglacial period MIS 5 and a negative correlation with most interglacial periods (MIS 1, MIS 3, MIS 7, and MIS 9) as well as the glacial period MIS 2. PC1 has a positive correlation with all five proxies while PC2 has a positive correlation with $\% \mathrm{CaCO}_{3}, \delta^{15} \mathrm{~N}, \% \mathrm{TOC}$, and $\delta^{13} \mathrm{C}$ and a negative correlation with $\% \mathrm{TN}$.

\begin{tabular}{llllll}
\hline & $\mathbf{\% C a C O}_{\mathbf{3}}$ & $\mathbf{\% T O C}$ & $\mathbf{\% T N}$ & $\boldsymbol{\delta}^{\mathbf{1 3}} \mathbf{C}$ & $\boldsymbol{\delta}^{\mathbf{1 5}} \mathbf{N}$ \\
\hline $\mathbf{t}$ & -1.69 & 0.78 & 1.75 & -0.53 & -1.92 \\
$\mathbf{d f}$ & 250 & 227 & 233 & 228 & 250 \\
$\mathbf{p}$ & 0.09 & 0.43 & 0.08 & 0.60 & 0.06 \\
\hline
\end{tabular}

Table 4.1. T-test scores for $\% \mathrm{CaCO}_{3}, \% \mathrm{TOC}, \% \mathrm{TN}, \delta^{13} \mathrm{C}$, and $\delta^{15} \mathrm{~N}$ between glacial $(\mathrm{n}=119)$ and interglacial $(\mathrm{n}=135)$ periods. In T-test analysis, $\mathrm{t}=\mathrm{t}$-value where larger values indicate significant differences between the sample mean and null hypothesis; $\mathrm{df}=$ degrees of freedom or the number of independent sample values; $p=$ probability value to determine statistical significance. 

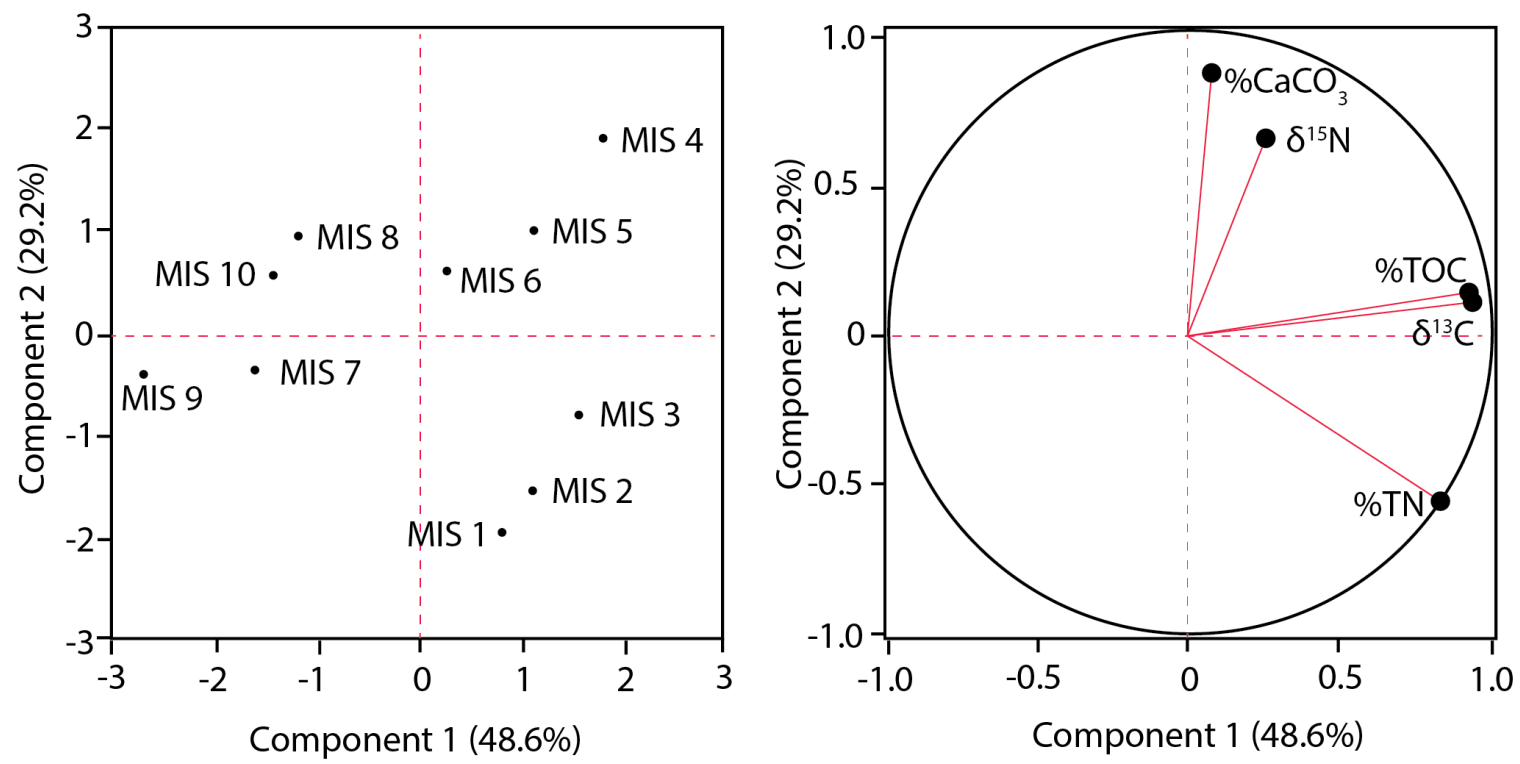

Figure 4.4. Principal component analysis (PCA) results for Site U1429 comparing the geochemical proxies during different marine isotope stages (MIS 1 to MIS 10).

\subsection{Discussion}

The controls on the rates of primary productivity occurring within surface waters are related to numerous physical and biochemical parameters, such as nutrient concentration, light penetration, temperature, and salinity. Relative paleoproductivity values can be reconstructed through the use of organic matter geochemical analyses in sedimentary sequences. Increased concentrations of $\mathrm{CaCO}_{3}, \mathrm{TOC}$, and $\mathrm{TN}$, and isotopic enrichment of their respective stable isotopes, $\delta^{13} \mathrm{C}$ and $\delta^{15} \mathrm{~N}$, indicate increased rates of primary productivity occurring within the eutrophic zone of water columns (Fry \& Sherr, 1984; Peterson \& Howarth, 1987).

Carbonate concentration within marine sedimentary sequences is generally controlled by three main factors: biogenic carbonate production, dilution as a result of increased terrestrial input, and the degree of preservation and/or dissolution after 
deposition (Chang et al., 2005). The shallow water depth (732 mbsl) of Site U1429 (Tada et al., 2015) indicates that this site has remained above the carbonate compensation depth (CCD) and is unlikely to be significantly affected by dissolution (Hyun et al., 2007). Therefore, $\mathrm{CaCO}_{3}$ concentrations at Site $\mathrm{U} 1429$ are likely relative indicators of marine productivity and/or terrestrial input. Although a distinct glacial/interglacial differentiation is not apparent within the carbonate data, three apparent $\sim 100$ ky cycles are present. With the exception MIS 1, all interglacial periods show increasing carbonate concentrations in the later portion of the interglacial period, and glacial transitions begin a gradual decrease in $\% \mathrm{CaCO}_{3}$ concentration. Carbonate concentration shows the greatest variance in sediments older than $250 \mathrm{ka}$, corroborating shipboard conclusions of interbedded sand layers near the base of Unit 1.

During interglacial periods, EASM conditions are typically intensified, leading to significant increases in precipitation across East Asia. As precipitation and the resulting freshwater input through the Yangtze and Yellow River discharges increase, upwelling along the ECS shelf intensifies, bringing cooler, nutrient-rich water to the surface (Chang et al., 2009). The CCW, a mixture of Yangtze, Yellow, and Minjiang River discharges along the Chinese coast (Wong et al., 2000), is nutrient- rich but deficient in phosphate, resulting in limited primary productivity in surface waters (Chen et al., 2004). When the phosphorous-rich Kuroshio Intermediate Water upwells, it increases the amount of primary productivity, including carbonate productivity, occurring within the upper water column (Chang et al., 2005).

During glacial periods, carbonate concentration is likely diluted as a result of increased terrestrial input as the continental shelf is exposed and the Yangtze and Yellow 
Rivers migrate towards the Okinawa Trough and deposit directly into the Danjo Basin where Site U1429 is located (Chang et al., 2005), as indicated by the relationship between $\delta^{18} \mathrm{O}$ of benthic foraminifera and $\% \mathrm{CaCO}_{3}$ content of the sediment (Corliss, 1985). Terrestrial materials are usually trapped near the mouths of these rivers (Anderson et al., 2018; Zhao et al., 2018), so the close proximity $(150-400 \mathrm{~km})$ of these paleo-river mouths significantly increases the terrestrial material deposited on the shelf, potentially even providing direct input of fluvially transported terrestrial sediment into the Okinawa Trough (Li et al., 2015; Liu et al., 2009).

Although other studies have determined significant changes at Site U1429 between glacial and interglacial periods, most have focused on sediment provenance (Anderson et al., 2018; Beny et al., 2018; Zhao et al., 2018). Although previous studies do not investigate sea surface conditions, they are indirectly connected. T-test results indicated that there was no significant difference $(p>0.05)$ between glacial and interglacial periods within any of the five geochemical proxies studied at Site U1429 concerning primary paleoproductivity. Except for $\mathrm{CaCO}_{3}$, all other geochemical proxies increase in concentration to the present, likely corroborating increased monsoon intensity during the Pleistocene (Boulay et al., 2005; Sun et al., 2006). Throughout the $\sim 350,000$ year record, the elemental and isotopic data of TOC and TN remain relatively stable except for significant abrupt excursions during interglacial periods MIS 1, MIS 3, MIS 5, MIS 7, and MIS 9. Within these interglacial periods, stadial events occur during MIS 3.3, MIS 5.2, MIS 5.4, MIS 7.2, MIS 7.4, and MIS 9.2 during which periods of colder climate and expansion of ice sheets prevail (McManus et al., 1999; Stolz \& Baumann, 2010). During these stadial events, $\% \mathrm{CaCO}_{3}, \% \mathrm{TOC}$, and $\% \mathrm{TN}$ typically decrease in 
concentration $\left(\sim 30 \%, 1.5 \%\right.$, and $0.1 \%$, respectively), $\delta^{13} \mathrm{C}$ values become $\sim 2-3 \%$ more depleted, and $\delta^{15} \mathrm{~N}$ values become more enriched by up to $5 \%$.

The last interglacial period, MIS 5, has five isotopic substages (MIS 5.1 to MIS 5.5) based on foraminiferal $\delta^{18} \mathrm{O}$ variations (Shackleton and Opdyke, 1976), further updated by the LR04 global sea-level stack (Lisiecki \& Raymo, 2004). The climate during MIS 5 was generally unstable (An \& Porter, 1997; de Beaulieu \& Reille, 1992; Grootes et al., 1993; McManus et al., 1999), especially after MIS 5.5 (Adkins et al., 1997; Chapman \& Shackleton, 1999). Typical interglacial conditions persisted during MIS 5.1, 5.3, and 5.5 and stadial conditions were present during MIS 5.2 and 5.4 (Oppo et al., 2006). Seven major ice-rafted debris (IRD) events occurred during MIS 5 in the North Atlantic and Greenland (An \& Porter, 1997; Chapman \& Shackleton, 1999; Oppo et al., 2006), which indicates unstable ice sheets calving, rapidly melting, and depositing terrestrial materials within marine sediments (Andrews, 2000). Most of these IRD events occur directly after stadials, especially the high amplitude IRD peak events C24 in MIS 5.2 and C21 during MIS 5.4 (Chapman \& Shackleton, 1999), indicating abrupt, shortlived glacial-like conditions during the interglacial period. The presence of volcanic tephra layer Aso-4 during MIS 5.2 could also obstruct the carbon and nitrogen paleoproductivity signals, so this stadial event should be interpreted with caution at Site U1429.

The penultimate interglacial period, MIS 7, is also divided into five distinct oxygen isotope substages, MIS 7.1 to 7.5 with stadial conditions during MIS 7.2 and MIS 7.4 (Lisiecki \& Raymo, 2004). MIS 7.4 was significantly longer lasting and colder than MIS 7.2 (Desprat et al., 2006). Within this stadial period, sea levels were $\sim 70 \mathrm{~m}$ lower 
than present (Siddall et al., 2007; Spötl et al., 2008) and indicate a "prominent glacial pulse" (Ruddiman et al., 1977) during the interglacial period. The second cold period, MIS 7.2, is less than one-fourth of the duration of MIS 7.4 and is usually not easily identified in marine sedimentary records in comparison to terrestrial speleothem records (Spotl et al., 2008). Several marine studies from the North Atlantic (McManus et al., 1999; Chapman \& Shackelton, 1999), however, indicate significant IRD deposits during both MIS 7.2 and MIS 7.4 (McManus et al., 1999). Multiproxy analysis of a deep sea core from the Iberian margin (Desprat et al., 2006) indicates that MIS 7.4 was very unusual, even for a stadial event, during interglacial periods. Low temperatures during this substage have been identified in Antarctica (Petit et al., 1999), the southwest Pacific (Pahnke et al., 2003), and the tropical Pacific (Lea et al., 2000), which likely indicates massive ice sheet growth. The significantly lower temperatures and enlargement of ice sheets during MIS 7.4 is similar to the glacial period MIS 8 (Desprat et al., 2006), and the $\mathrm{CO}_{2}$ concentrations within the Vostok ice core during both MIS 7.4 and MIS 8 are nearly equal (Petit et al., 1999).

In addition to the last and penultimate interglacial periods, two other negative excursions are present in the paleoproductivity record. The minor negative excursion present during the shorter interglacial period of MIS 3, specifically the MIS 3.3 event would at first appear to be similar to the other stadial events discussed. While MIS 3 was traditionally categorized as an interglacial period, recent literature suggests that the duration of MIS 2 to MIS 4 be treated as one long glacial period with MIS 3 acting as a long-lived interstadial event (Berger et al., 2016). Therefore, the negative excursion present in MIS 3 has not been included with the stadial events in this study. A second 
major negative excursion near the end of MIS 9.2 is also identified within the paleoproductivity record. It could be the result of another stadial event, but the low sample resolution of this stage precludes any definitive analysis. More samples are necessary from this time period to better understand the stadial events during MIS 9.

During glacial periods, significant portions of the ECS shelf is exposed and the Yellow and Yangtze Rivers migrate farther south. As fluvial flux increases, it would be expected that the organic matter preserved would shift to a more terrestrial signal, i.e., increases in TOC and depletion in $\delta^{13} \mathrm{C}$, during glacial periods. At Site U1429, however, the $\delta^{13} \mathrm{C}$ record (Black et al., 2018) only indicates a relatively higher terrestrial source during short term stadial events of interglacial periods, not during glacial periods. The lack of terrestrial source signals during glacials could be the result of fluvial material being trapped near the Yangtze and Yellow River paleo-deltas (Zhao et al., 2018) and not being deposited within the Okinawa Trough. During glacial periods, the EAWM is typically intensified, increasing the wind speed and the resulting upwelling along the path of the Kuroshio Current (Ujiié \& Ujiié, 1999; Xu \& Oda, 1999). Increased EAWM conditions have been associated with millennial-scale abrupt cold excursions in the subtropical North Pacific (Li et al., 2017; Yang \& Ding, 2014).

During interglacial periods, EASM intensity increases, which increases the precipitation within the drainage basins of the Yellow and Yangtze Rivers, increasing freshwater flux into the ECS, therefore increasing upwelling of the Kuroshio Current (Chang et al., 2009)(Figure 4.5). Stadial events occurring during interglacial periods typically indicate decreases in both sea and air temperature as well as increases in northern hemispheric ice volume, signifying colder environments than the typically 
warmer interglacial conditions, acting like a short-lived glacial period (Cheng et al., 2016; McManus et al., 1999; Stolz et al., 2010). With increased precipitation occurring during the EASM and increased wind intensity during the EAWM, the Kuroshio Current, and its related Kuroshio Intermediate Water is upwelled nearly year-round. The upwelled Kuroshio Intermediate Water provides the nutrients necessary, especially phosphorous, to increase rates of primary productivity within surface waters of the ECS (Chang et al., 2009).

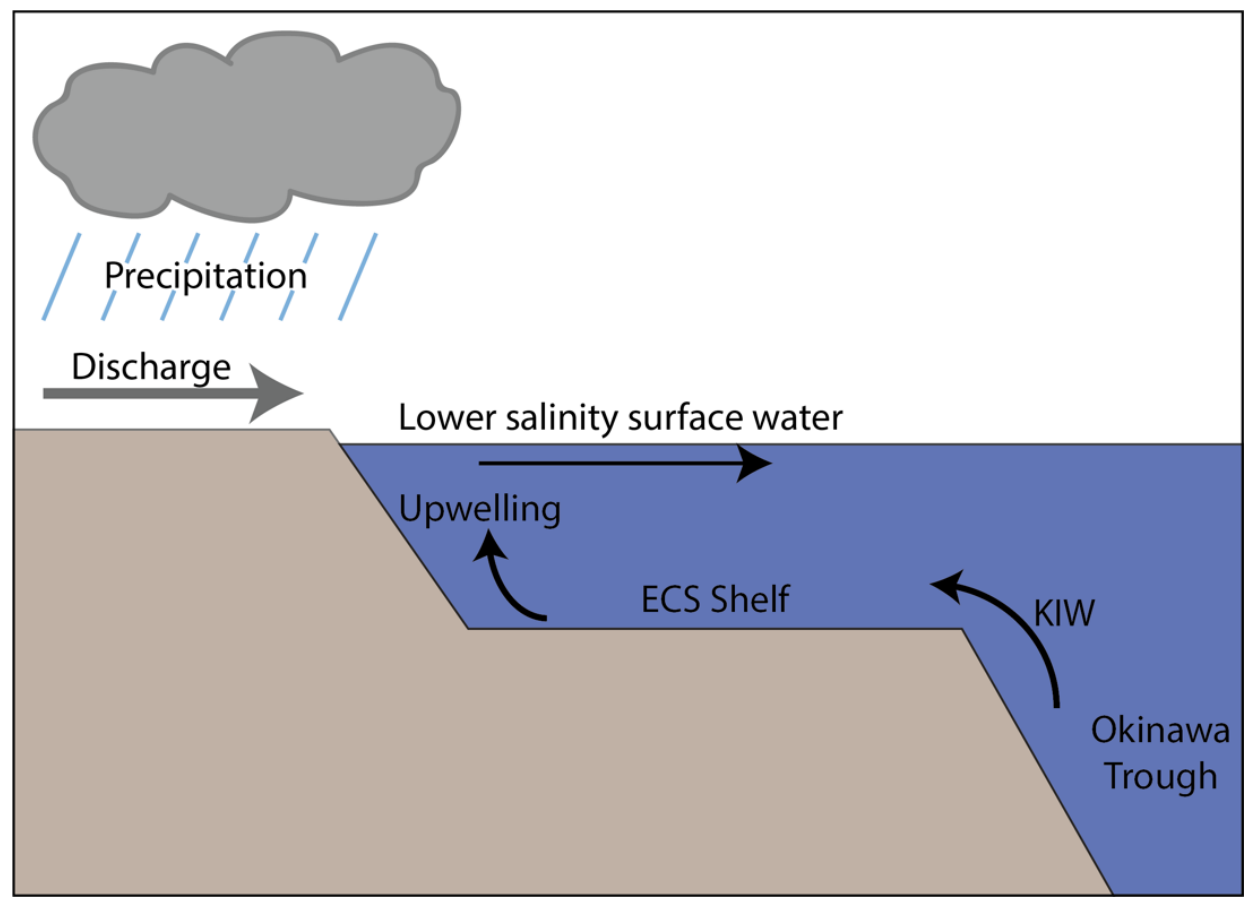

Figure 4.5. A conceptual model of increased EASM precipitation and the resulting Yangtze River discharge onto the East China Sea shelf. Lower salinity surface water from increased fluvial discharge is transported further offshore, inducing upwelling of the Kuroshio Intermediate Water (KIW) in the Okinawa Trough, which increases primary productivity levels within the East China Sea. (Modified from Chang et al., 2009.)

A significant difference between glacial and interglacial periods was not present in Site U1429's carbon and nitrogen record as a result of the constant presence of the 
Kuroshio Current flowing through the East Taiwan Strait and upwelling of the Kuroshio Current along the shelf break. The presence and degree of Kuroshio intrusion into the ECS during glacial periods has been heavily debated within the paleoceanographic community and only recently have indications that the Kuroshio has been a constant fixture within the ECS been moderately accepted (Gallagher et al., 2015). This study identifies a nearly constant primary productivity level over the sedimentary record except for four stadial events during MIS 5 and MIS 7, likely indicating nearly continuous input of the Kuroshio Current through the East Taiwan Strait during at least the past $\sim 350 \mathrm{ky}$. The path of the Kuroshio Current along the shelf break in addition to increased precipitation during EASM and increased wind intensity during EAWM would allow continuous upwelling of the Kuroshio Intermediate Water and therefore relatively constant rates of net primary productivity.

If inflow of the Kuroshio Current into the ECS is limited during glacial periods, as some have defended (Ujiie \& Ujiie, 1999; Ujiie et al., 2003), most of the nutrient flux into the Okinawa Trough would be from Yangtze and Yellow River discharges through the CCW (Anderson et al., 2018; Beny et al., 2018; Zhao et al., 2017, 2018). The Yangtze River presently accounts for $80 \%$ of the total freshwater discharge into the ECS (Ichikawa \& Beardsley, 2002), and although it has high nitrate concentrations, it is deficient in bio-limiting phosphate (Chen et al., 2004), which limits the amount of primary production that can occur within surface waters. The N:P ratio of the rivers contributing to the Chinese Coastal Water is 111 (Chen, 2000), which is significantly higher than the Redfield Ratio of 16 necessary for the production of phytoplankton (Geider \& La Roche, 2002). Such a high N:P ratio likely indicates reduced productivity 
as a result of the bio-limiting phosphorus deficiency or excessive $\mathrm{N}$ from terrestrial sources. Increased precipitation, and the resulting fluvial transport of nutrients would increase primary productivity in the surface waters to a certain extent, but without the upwelled Kuroshio Intermediate Water and its high phosphorous concentrations, net productivity would be limited (Chen, 1996; Chen \& Wang, 1999).

During stadial events of interglacial periods, negative excursions are present in the otherwise relatively stable carbon and nitrogen records. The relatively quick emergence of a cold stadial event during an otherwise warm interglacial might limit the flux of the Kuroshio through the East Taiwan Strait such that the resulting eddy northeast of Taiwan weakened, decreasing upwelling of the Kuroshio Intermediate Water and limiting cross shelf transport of POM through the Okinawa Trough (Kim \& Yoon, 1999; Wong et al., 2000). Instead, potential fluvial signatures are present within the carbon isotope data during these stadials, likely indicating that there is increased deposition of Yellow River sediments. The TOC contents of the sediment during these stadial events, however, decreases in concentration and therefore does not indicate increased terrestrial input, as carbon would be expected to increase as a result of higher lignin concentrations in terrestrial material (Prahl et al., 1994). It can be argued instead that the stadial events are identifying periods of decreased upwelling of the Kuroshio Current, which would limit primary production as a result of phosphate deficiencies. The TN content of the preserved sediment would not serve as a good differentiator of upwelled vs. fluvial source of the nutrients necessary for primary productivity as a result of the significance of Yangtze River discharge and its excess N loading to the ECS (Chen, 2004). 
Upwelling within the ECS occurs on the basis of three factors: the bathymetry of the shelf break along the Okinawa Trough (Wong et al., 2000), freshwater input through the Yangtze and Yellow Rivers (Chang et al., 2009), and flow rate of the Kuroshio Current through the East Taiwan Strait (Wong et al., 2000). It is likely that the Kuroshio Current has continuously flowed through the East Taiwan Strait (Gallagher et al., 2015), which would limit upwelling to two factors: freshwater input and the Kuroshio Current flow rate into the ECS. Decreased upwelling of the Kuroshio Intermediate Water could be caused by decreased monsoonal conditions (Chen et al., 2004; Chang et al., 2009). If the EASM decreased in intensity, it would decrease upwelling rates by decreasing freshwater discharge (Diekmann et al., 2008) while if the EAWM intensity decreased, it would limit wind intensity and the resulting upwelling along the shelf break in the ECS (Kawahata et al., 2006). On this basis, it is likely that during stadial events in MIS 5 and MIS 7, decreased monsoon intensities prevailed, decreasing upwelling of the Kuroshio Current and a corresponding decrease in primary productivity within the ECS.

At present, only two studies within the Danjo Basin of the Okinawa Trough have been published with sedimentary records older than $\sim 85$ ky (Anderson et al., 2018; Beny et al., 2018), and are therefore long enough to investigate stadial events during MIS 5 and MIS 7. Although both studies focus on the sediment provenance instead of surface processes within the ECS, the use of $\mathrm{SiO}_{2} / \mathrm{AlO}_{3}(\mathrm{~g} / \mathrm{g})$ and $\mathrm{Ca} / \mathrm{Fe}$ ratios can give a better understanding of the grain size and terrestrial influence throughout time at Site U429. Anderson (2018) identified increased $\mathrm{SiO}_{2} / \mathrm{AlO}_{3}$ values during or near MIS 5.4, MIS 7.2, and MIS 7.4, indicating increased terrigenous contribution during these stadial events. The $\mathrm{SiO}_{2} / \mathrm{AlO}_{3}$ values during these stadial events were the highest throughout their $\sim 400$ 
ky record, even in comparison to glacial periods when higher terrestrial inputs would be expected. Interglacial periods at Site U1429 typically have higher $\mathrm{Ca} / \mathrm{Fe}$ ratios (Beny et al., 2018), however, negative excursions within the XRF data also exist within stadial events MIS 5b (5.2), MIS 5d (5.4), MIS 7b (7.2), and MIS 7d (7.4)(Figure 4.5), indicating a more terrestrial influence during these time periods (Beny et al., 2018). ${ }^{10}$

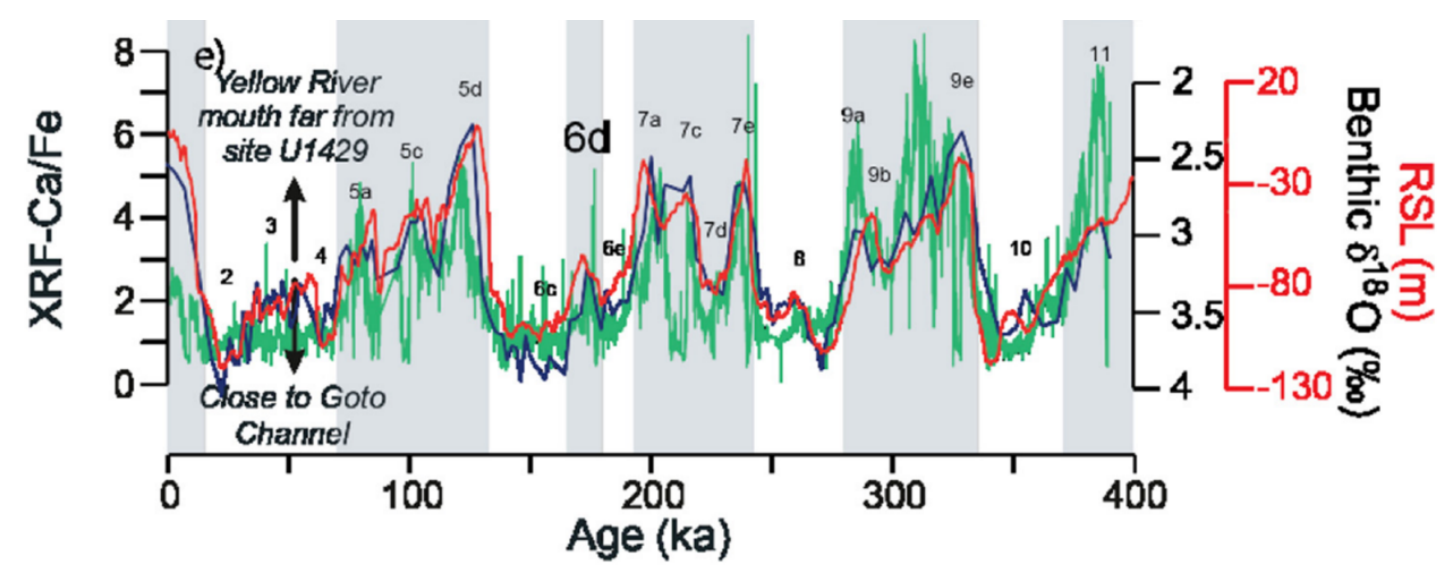

Figure 4.6. $\mathrm{Ca} / \mathrm{Fe}$ (green line), benthic $\delta^{18} \mathrm{O}$ (black line; Sagawa et al., 2018), and relative sea level (RSL; red line) data for Site U1429 (Modified from Beny et al., 2018).

Gravity flow layers, such as turbidites, are typically identified by sorting sequences but can also be qualitatively identified through the use of other physical and chemical properties such as low concentrations of $\mathrm{CaCO}_{3}$ and $\mathrm{TOC}$, low $\mathrm{Ca} / \mathrm{Fe}$ ratios, and high $\mathrm{SiO}_{2} / \mathrm{AlO}_{3}$ ratios. The combination of the geochemical proxies in this study, in addition to $\mathrm{SiO}_{2} / \mathrm{AlO}_{3}$ and $\mathrm{Ca} / \mathrm{Fe}$ ratios indicate the possible presence of gravity flow layers during these stadial events. Gravity flow layers are typically fine- or coarsegrained muds indicative of submarine fans (Yu et al., 2017). Sloping shelves, like that of the ECS shelf break, can trigger density-based avalanches and climate-controlled pulses

\footnotetext{
${ }^{10}$ Lettered MIS substages are continuous intervals of time while decimal-style substages are discrete events (Railsback et al., 2015).
} 
of sediment supply (Lehu et al., 2015). The morphological characteristics of the ECS are dominated by marine landslides, debris flows, and turbidity currents (Ramsey et al., 2006). The Okinawa Trough is not only one of the most tectonically active regions in the world but is also affected by monsoon dynamics (Lehu et al., 2015), which can increase the marine erosional processes that may lead to gravity flow layer deposition.

The Kuroshio Current is an essential component in the transport of suspended materials within the Okinawa Trough (Lehu et al., 2015). If the Kuroshio Current decreased in volume or flow rate during stadial events, the water mass would be limited in the concentration of suspended materials it could transport and deposition of coarsegrained sediments would be expected within the Okinawa Trough, as shown by significantly increased $\mathrm{SiO}_{2} / \mathrm{AlO}_{3}$ ratios at Site U1429 (Anderson et al., 2018). A reduction in the Kuroshio Current would also lead to an increase of terrestrial material deposited, as indicated by a decrease in $\mathrm{Ca} / \mathrm{Fe}$ values that are more typical of glacial periods than interglacial periods (Beny et al., 2018). According to low-resolution Expedition 346 shipboard analyses, interbedded sand layers typical of turbidites are common from $242 \mathrm{ka}$ throughout the end of the record where Site U1429 drilling was terminated as a result of the presence of a thick, sandy turbidite layer that impeded further collection (Tada et al., 2015). It is therefore likely that the abrupt excursions of geochemical data present during stadial events in MIS 5 and MIS 7 are also as a result of gravity flow layers preserved in the sedimentary sequences at this site. 


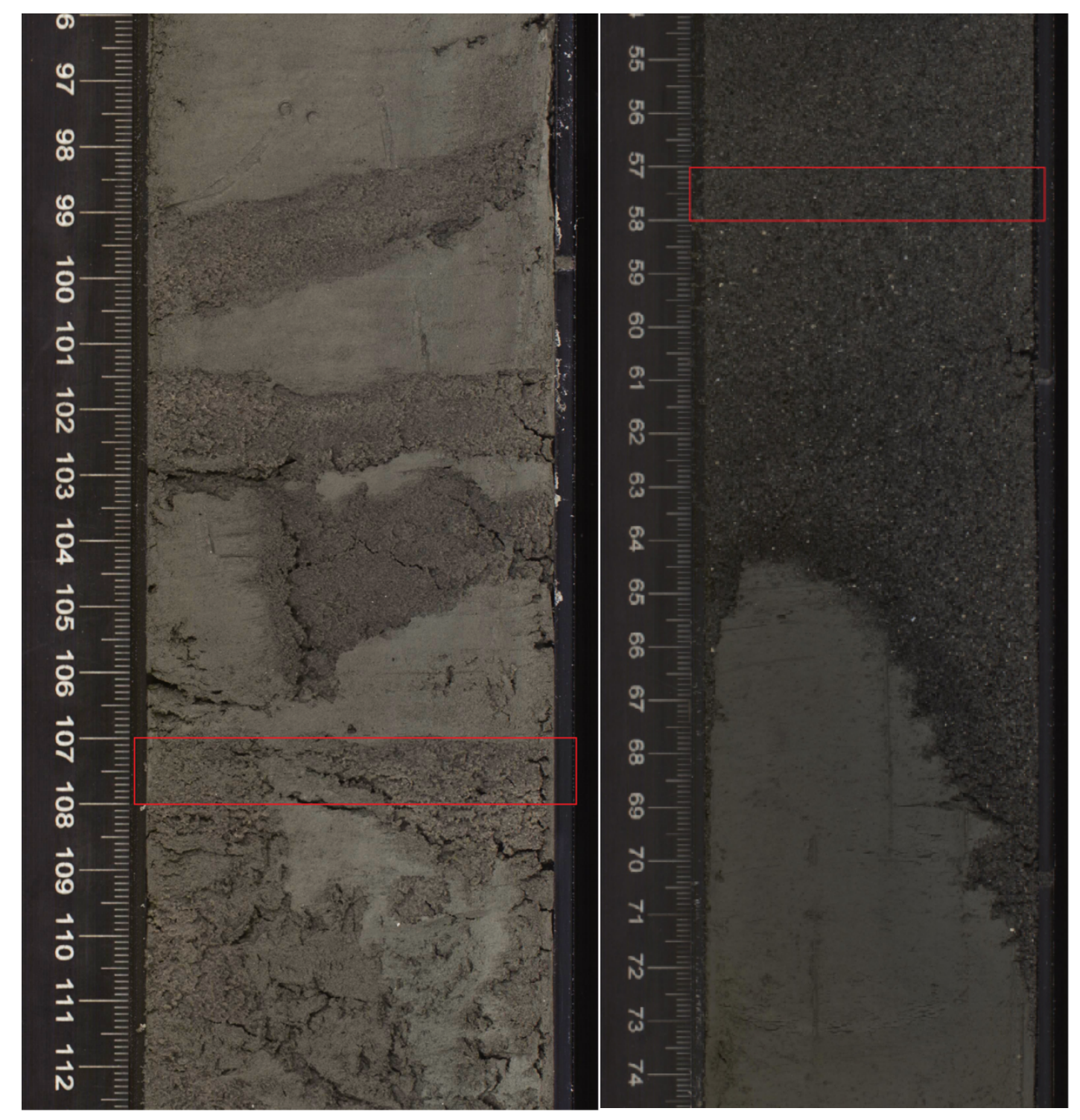

Figure 4.7. Shipboard core section images of Site U1429 sediment show interbedded sand layers indicative of potential gravity flow layers. a) Sample U1429A-13H-4W-107$108 \mathrm{~cm}$ from MIS 5.2 and b) sample U1429A-15H-1W-57-58cm from MIS 7.4.

Other short-lived excursions of the elemental and isotopic record during MIS 1, MIS 5, MIS 8, and MIS 10 exist outside of the stadial events. The decrease in elemental concentrations and isotopic depletion at $6 \mathrm{ka}$ and $350 \mathrm{ka}$ are likely a result of the presence of tephra layers K-Ah and Kkt within the sediments of Site U1429 (Sagawa et al., 2018). 
Three other tephra layers, Sz-S, Aso-4, and Aso-1, are also present within the study site at $14 \mathrm{ka}, 91 \mathrm{ka}$, and $266 \mathrm{ka}$, respectively (Sagawa et al., 2018), which are identified by rapid oscillations in $\% \mathrm{CaCO}_{3}, \% \mathrm{TOC}$, and $\delta^{13} \mathrm{C}$ values. These tephra layers can, therefore, be excluded from analysis because of the volcanic nature of the sample diluting potential terrestrial and oceanic source signals. Tephra layer Sz-S (14 ka) was deposited directly after Termination $\mathrm{T} 1$ between the last glacial and current interglacial period. The short-lived but large amplitude oscillations during this time could also be a result of rapidly changing environmental conditions as the last glacial period ended and rapidly increasing sea levels prevailed, or the preservation of volcanic material.

While this study focused on the carbon and nitrogen records preserved at Site U1429, additional work is necessary to better understand the role of the Kuroshio Current, upwelling intensity, and the resulting paleoproductivity rates within the ECS. Additional geochemical and biogenic proxy records from Site U1429, such as opal content, foraminifera and radiolarian abundances, and lipid biomarkers, would ideally improve the discussion by including other parameters to measure primary productivity rates. At this time, however, only a limited number of data sets have been published from the northern end of the Okinawa Trough, especially from Site U1429. Future publications from IODP Expedition 346 will allow better collaboration, and therefore better interdisciplinary interpretations of the sedimentary record of the ECS, including upwelling and paleoproductivity rates. 


\subsection{Conclusions}

The ECS consists of the wide, shallow epicontinental shelf and the significantly deeper Okinawa Trough. With glacio-eustatic sea level variations, various amounts of the ECS shelf have been exposed during glacial/interglacial periods. It would be expected that during sea level low stands, migration of the Yellow and Yangtze Rivers over the shelf to the northern end of the Okinawa Trough would deposit terrestrially sourced material during glacial low stands while interglacial periods leave the shelf submerged, allowing for better cross-shelf transport of materials. Although a clear differentiation of glacial and interglacial periods was not found at Site U1429, it is likely a result of nearly constant upwelling of the Kuroshio Current, regardless of sea level variation within the ECS.

The presence and intensity of the Kuroshio Current entering the ECS through the East Taiwan Strait causes intense upwelling of the nutrient-rich subsurface Kuroshio Intermediate Water along the continental shelf break. Increased upwelling transfers more bio-limiting nutrients to the surface, promoting elevated primary productivity rates. The carbonate contents at Site U1429 have a clear inverse relationship with sea level while the carbon and nitrogen elemental and isotopic data are relatively stable throughout the $\sim 350,000$-year sedimentary record. However, significant negative excursions of the geochemical data occur during stadial events within the interglacial periods of the study period, specifically MIS 5.2, MIS 5.4, MIS 7.2, and MIS 7.4.

It is still debated whether or not the Kuroshio Current entered the ECS during glacial periods or instead flowed east of the Ryukyu Arc to the Pacific. The relative stability of the TOC, TN, and $\delta^{13} \mathrm{C}$ contents of the sediment at Site U1429 indicate a 
constant influx of the Kuroshio Current through the East Taiwan Strait during both interglacial and glacial periods. Abrupt, negative excursions of these geochemical proxies occur during stadial events, identifying decreased rates of net productivity, likely a result of decreased upwelling of the Kuroshio Intermediate Water as a result of decreased monsoonal conditions associated with the EASM and EAWM. Potential gravity flows could also be the source of the negative excursions during stadial events, but future research will clarify the sedimentology.

\subsection{References}

Adkins, J.F., Boyle, E.A., Keigwin, L., \& Cortijo, E. (1997). Variability of the North Atlantic thermohaline circulation during the last interglacial period. Nature, 390, 154-156. https://doi.org/10.1038/36540

Ahagon, N., Tanaka, Y., \& Ujjie, H. (1993). Florisphaera profunda, a possible nannoplankton indicator of late Quaternary changes in seawater turbidity at the northwestern margin of the Pacific. Marine Micropaleontology, 22, 255-273.

An, Z. \& Porter, S.C. (1997). Millennial-scale climatic oscillations during the last interglaciation in central China. Geology, 25(7), 603-606. https://doi.org/10.1130/0091-7613(1997)025<0603:MSCODT>2.3.CO;2

Anderson, C.H., Murray, R.W., Dunlea, A.G., Giosan, L., Kinsley, C.W., McGee, D.,et al. (2018). Climatically Driven Changes in the Supply of Terrigenous Sediment to the East China Sea. Geochemistry, Geophysics, Geosystems, 19(8), 2463-2477. https://doi.org/10.1029/2017GC007339

Andrews, J.T. (2000). Icebergs and iceberg rafted detritus (IRD) in the North Atlantic: facts and assumptions. Oceanography, 100, 100-108. https://doi.org/10.1016/S1473-3099(16)00095-5

Beardsley, R.C., Limeburner, R., Yu, H., \& Cannon, G.A. (1985). Discharge of the Changjiang (Yangtze River) into the East China Sea. Continental Shelf Research, 4, 57-76. https://doi.org/10.1016/0278-4343(85)90022-6 
de Beaulieu, J.L. \& Reille, M. (1992). The last climatic cycle at La Grande Pile (Vosges, France) a new pollen profile. Quaternary Science Reviews, 11(4), 431-438. https://doi.org/10.1016/0277-3791(92)90025-4

Beny, F., Toucanne, S., Skonieczny, C., Bayon, G., \& Ziegler, M. (2018). Geochemical provenance of sediments from the northern East China Sea document a gradual migration of the Asian Monsoon belt over the past 400,000 years. Quaternary Science Reviews, 190, 161-175. https://doi.org/10.1016/j.quascirev.2018.04.032

Berger, B., Crucifix, M., Hodell, D.A., Mangili, C., McManus, J.F., Otto-Bliesner, B., et al. (2016). Interglacials of the last 800,000 years. Reviews of Geophysics, 54(1), 162-219. https://doi.org/10.1002/2015RG000482

Boneau, C.A. (1960). The effects and violations of assumptions underlying the t Test. Psychological Bulletin, 57(1), 49-64.

Boulay, S., Colin, C., Trentesaux, A., Frank, N., \& Liu, Z. (2005). Sediment sources and East Asian monsoon intensity over the last $450 \mathrm{ky}$. Mineralogical and geochemical investigations on South China Sea sediments. Palaeogeography, Palaeoclimatology, Palaeoecology, 228, 260-277. https://doi.org/10.1016/j.palaeo.2005.06.005

Chang, Y.P., Wu, S.M., Wei, K.Y., Murayama, M., Kawahata, H., \& Chen, M. (2005). Foraminiferal oxygen isotope stratigraphy and high-resolution organic carbon, carbonate records from the Okinawa Trough (IMAGES MD012404 and ODP Site 1202). Terrestrial, Atmospheric and Oceanic Sciences, 16(1), 57-73.

DOI: 10.3319/TAO.2005.16.1.57(OT)

Chang, Y.P., Chen, M., Yokoyama, Y., Matsuzaki, H., Thompson, W.G., Kao, S.J., \& Kawahata, H. (2009). Monsoon hydrography and productivity changes in the East China Sea during the past 100,000 years: Okinawa Trough evidence (MD012404). Paleoceanography, 24(3). https://doi.org/10.1111/odi.12396

Chapman, M.R., \& Shackleton, N.J. (1999). Global ice-volume fluctuations, North Atlantic ice-rafting events, and deep-ocean circulation changes between 130 and 70 ka. Geology, 27(9), 795-798. https://doi.org/10.1130/00917613(1999)027<0795:GIVFNA>2.3.CO;2

Chen, C.A. (1996). The Kuroshio intermediate water is the major source of nutrients on the East China Sea continental shelf. Oceanologica Acta, 19, 523-527.

Chen, C.T.A. (2000). The Three Gorges Dam: Reducing the upwelling and thus productivity in the East China Sea. Geophysical Research Letters, 27(3), 381-383. https://doi.org/10.1029/1999GL002373 
Chen, C.T.A., Ruo, R., Paid, S. C., Liu, C. T., \& Wong, G.T.F. (1995). Exchange of water masses between the East China Sea and the Kuroshio off northeastern Taiwan. Continental Shelf Research, 15(1), 19-39. https://doi.org/10.1016/02784343(93)E0001-O

Chen, Y.L.L., Chen, H.Y., Gong, G.C., Lin, Y.H., Jan, S., \& Takahashi, M. (2004). Phytoplankton production during a summer coastal upwelling in the East China Sea. Continental Shelf Research, 24(12), 1321-1338. https://doi.org/10.1016/j.csr.2004.04.002

Cheng, H., Edwards, R.L., Broecker, W.S., Denton, G.H., Kong, X., Wang, Y., et al. (2009). Ice age terminations. Science, 326(5950), 248-252. https://doi.org/10.1126/science. 1177840

Coplen, T.B. (2011). Guidelines and recommended terms for expression of stableisotope-ratio and gas-ratio measurement results. Rapid Communications in Mass Spectrometry, 25(17), 2538-2560. https://doi.org/10.1002/rcm.5129

Corliss, B.H. (1985). Microhabitats of benthic foraminifera within deep-sea sediments. Nature, 314, 435-438. https://doi.org/10.1038/314435a0

Desprat, S., Sánchez Goñi, M.F., Turon, J.L., Duprat, J., Malaizé, B., \& Peypouquet, J.P. (2006). Climatic variability of Marine Isotope Stage 7: direct land-sea-ice correlation from a multiproxy analysis of a north-western Iberian margin deep-sea core. Quaternary Science Reviews, 25, 1010-1026. https://doi.org/10.1016/j.quascirev.2006.01.001

Diekmann, B., Hofmann, J., Henrich, R., Fütterer, D.K., Röhl, U., \& Wei, K.Y. (2008). Detrital sediment supply in the southern Okinawa Trough and its relation to sealevel and Kuroshio dynamics during the late Quaternary. Marine Geology, 255, 83-95. https://doi.org/10.1016/j.margeo.2008.08.001

Dou, Y., Yang, S., Liu, Z., Clift, P.D., Yu, H., Berne, S., \& Shi, X. (2010). Clay mineral evolution in the central Okinawa Trough since $28 \mathrm{ka}$ : Implications for sediment provenance and paleoenvironmental change. Palaeogeography, Palaeoclimatology, Palaeoecology, 288, 108-117. https://doi.org/10.1016/j.palaeo.2010.01.040

Fry, B. \& Sherr, E.B. (1984). ${ }^{13} \mathrm{C}$ measurements as indicators of carbon flow in marine and freshwater ecosystems. Contributions in Marine Science, 27, 13-47. DOI: 10.1007/978-1-4612-3498-2 12 
Gallagher, S.J., Kitamura, A., Iryu, Y., Itaki, T., Koizumi, I., \& Hoiles, P.W. (2015). The Pliocene to recent history of the Kuroshio and Tsushima Currents: a multi-proxy approach. Progress in Earth and Planetary Science, 2(17). https://doi.org/10.1186/s40645-015-0045-6

Geider, R.J. \& La Roche, J. (2002). Redfield revisited: Variability of C:N:P in marine microalgae and its biochemical basis. European Journal of Phycology, 37, 1-17. https://doi.org/10.1017/S0967026201003456

Grootes, P.M., Stuiver, M., White, J.W.C., Johnsen, S., \& Jouzel, J. (1993). Comparison of oxygen isotope records from the GISP2 and GRIP Greenland ice cores. Nature, 366, 552-554. https://doi.org/10.1038/366552a0

Guo, Q.Y. (1983). The strength index East Asian summer monsoon and its variation. Chinese Journal of Geography, 38, 207-217.

Hayes, J.M. (1982). Fractionation et al.: An introduction to isotopic measurements and terminology. Spectra, 8, 3-8.

Hyun, S., Bahk, J.J., Suk, B.C., \& Park, B.K. (2007). Alternative modes of Quaternary pelagic biosiliceous and carbonate sedimentation: A perspective from the East Sea (Japan Sea). Palaeogeography, Palaeoclimatology, Palaeoecology, 247(1-2), 8899. https://doi.org/10.1016/j.palaeo.2006.11.023

Ichikawa, H. \& Beardsley, R.C. (2002). The current system in the Yellow and East China Seas. Journal of Oceanography, 58(1), 77-92. https://doi.org/10.1023/A:1015876701363

Irino, T., Tada, R., Ikehara, K., Sagawa, T., Karasuda, A., Kurokawa, et al. (2018). Construction of perfectly continuous records of physical properties for dark-light sediment sequences collected from the Japan Sea during Integrated Ocean Drilling Program Expedition 346 and their potential utilities as paleoceanographic studies. Progress in Earth and Planetary Science, 5(18), 1-23. https://doi.org/https://doi.org/10.1186/s40645-018-0176-7

Jian, Z., Wang, P., Saito, Y., Wang, J., Pflaumann, U., Oba, T., \& Cheng, X. (2000). Holocene variability of the Kuroshio current in the Okinawa trough, Northwestern Pacific Ocean. Earth and Planetary Science Letters, 184(1), 305-319. https://doi.org/10.1016/S0012-821X(00)00321-6

Kawahata, H., Nohara, M., Aoki, K., Minoshima, K., \& Gupta, L.P. (2006). Biogenic and abiogenic sedimentation in the northern East China Sea in response to sea-level change during the Late Pleistocene. Global and Planetary Change, 53, 108-121. https://doi.org/10.1016/j.gloplacha.2006.01.013 
Kim, C.H. \& Yoon, J.H. (1999). A numerical modeling of the upper and the intermediate layer circulation in the East Sea. Journal of Oceanography, 55(2), 327-345. https://doi.org/10.1023/A:1007837212219

Lea, D.W., Pak, D.K., \& Spero, H.J. (2000). Climate impact of late quaternary equatorial Pacific sea surface temperature variations. Science, 289(5485), 1719-1724. https://doi.org/10.1126/science.289.5485.1719

Lehu, R., Lallemand, S., Hsu, S.K., Babonneau, N., Ratzov, G., Lin, A.T., \& Dezileau, L. (2015). Deep-sea sedimentation offshore eastern Taiwan: Facies and processes characterization. Marine Geology, 369, 1-18. https://doi.org/10.1016/j.margeo.2015.05.013

Li, D., Zheng, L.W., Jaccard, S.L., Fang, T.H., Paytan, A., Zheng, X., et al. (2017). Millennial-scale ocean dynamics controlled export productivity in the subtropical North Pacific. Geology, 45(7), 651-654. https://doi.org/10.1130/G38981.1

Li, T., Xu, Z., Lim, D., Chang, F., Wan, S., Jung, H.S., \& Choi, J. (2015). Sr-Nd isotopic constraints on detrital sediment provenance and paleoenvironmental change in the northern Okinawa Trough during the late Quaternary. Palaeogeography, Palaeoclimatology, Palaeoecology, 430, 74-84. https://doi.org/10.1016/j.palaeo.2015.04.017

Lim, D.I., Kang, S., Yoo, H.S., Jung, H.S., Choi, J.Y., Kim, H.N., \& Shin, I.H. (2006). Late Quaternary sediments on the outer shelf of the Korea Strait and their paleoceanographic implications. Geo-Marine Letters, 26(5), 287-296. https://doi.org/10.1007/s00367-006-0039-x

Liu, J.P., Xue, Z., Ross, K., Wang, H.J., Yang, Z.S., Li, A.C., \& Gao, S. (2009). Fate of sediments delivered to the sea by Asian large rivers: Long-distance transport and formation of remote alongshore clinothems. The Sedimentary Record, 7(4), 4-9. DOI: $10.2110 /$ sedred.2009.4.4

Liu, J.P., Xu, K.H., Li, A.C., Milliman, J.D., Velozzi, D.M., Xiao, S.B., \& Yang, Z.S. (2007). Flux and fate of Yangtze River sediment delivered to the East China Sea. Geomorphology, 85, 208-224. https://doi.org/10.1016/j.geomorph.2006.03.023

McKinney, C.R., McCrea, J.M., Epstein, S., Allen, H.A., \& Urey, H.C. (1950). Improvements in mass spectrometers for the measurement of small differences in isotope abundance ratios. Review of Scientific Instruments, 21(724). https://doi.org/10.1063/1.1745698

McManus, J.F., Oppo, D.W., \& Cullen, J.L. (1999). A 0.5-Million-year record of millennial-scale climate variability in the North Atlantic. Science, 283(5404), 971-975. https://doi.org/10.1126/science.283.5404.971 
Nakagawa, T., Okuda, M., Yonenobu, H., Miyoshi, N., Fujiki, T., Gotanda, K., et al. (2008). Regulation of the monsoon climate by two different orbital rhythms and forcing mechanisms. Geology, 36(6), 491-494. https://doi.org/10.1130/G24586A.1

Oiwane, H., Tonai, S., Kiyokawa, S., Nakamura, Y., Suganuma, Y., \& Tokuyama, H. (2011). Geomorphological development of the Goto Submarine Canyon, northeastern East China Sea. Marine Geology, 288, 49-60. https://doi.org/10.1016/j.margeo.2011.06.013

Oppo, D.W., McManus, J.F., \& Cullen, J.L. (2006). Evolution and demise of the Last Interglacial warmth in the subpolar North Atlantic. Quaternary Science Reviews, 25, 3268-3277. https://doi.org/10.1016/j.quascirev.2006.07.006

Pahnke, K., Zahn, R., Elderfield, H., \& Schulz, M. (2003). 340,000-Year centennial-scale marine record of southern hemisphere climatic oscillation. Science, 301(5635), 948-952. https://doi.org/10.1126/science.1084451

Park, S.C., Yoo, D.G., Lee, C.W., \& Lee, E.I. (2000). Last glacial sea-level changes and paleogeography of the Korea (Tsushima) strait. Geo-Marine Letters, 20(2), 64-71. https://doi.org/10.1007/s003670000039

Peterson, B.J. \& Howarth, R.W. (1987). Sulfur, carbon, and nitrogen isotopes used to trace organic matter flow in the salt-marsh estuaries of Sapelo Island, Georgia. Limnology and Oceanography, 32(6), 1195-1213. https://doi.org/10.4319/1o.1987.32.6.1195

Petit, J.R., Jouzel, J., Raynaud, D., Barkov, N.., Barnola, J.M., Basile, I., et al. (1999). Climate and atmospheric history of the past 420,000 years from the Vostok ice core, Antarctica. Nature, 399, 429-436. https://doi.org/10.1038/20859

Prahl, F.G., Ertel, J.R., Goni, M.A., Sparrow, M.A., \& Eversmeyer, B. (1994). Terrestrial organic carbon contributions to sediments on the Washington margin. Geochimica et Cosmochimica Acta, 58(14), 3035-3048. https://doi.org/10.1016/00167037(94)90177-5

Railsback, L.B., Gibbard, P.L., Head, M.J., Voarintsoa, N.R.G., \& Toucanne, S. (2015). An optimized scheme of lettered marine isotope substages for the last 1.0 million years, and the climatostratigraphic nature of isotope stages and substages. Quaternary Science Reviews, 111(11), 94-106. https://doi.org/10.1016/j.quascirev.2015.01.012

Ramsey, L.A., Hovius, N., Lague, D., \& Liu, C.S. (2006). Topographic characteristics of the submarine Taiwan orogen. Journal of Geophysical Research: Earth Surface, 111(F2). https://doi.org/10.1029/2005JF000314 
Ren, M. \& Shi, Y. (1991). Sediment discharge of the Huanghe River and its effect on sedimentation of the Bohai Sea and the Yellow Sea. Chinese Geographical Science, 1(1), 1-18. https://doi.org/10.1007/BF02664452

Ruddiman, W.F., Sancetta, C.D., McIntyre, A., Manley, G., Dreimanis, A., \& Lamb, H.H. (1977). Glacial/Interglacial Response Rate of Subpolar North Atlantic Waters to Climatic Change: The Record in Oceanic Sediments [and Discussion]. Philosophical Transactions of the Royal Society of London. Series B, Biological Sciences, 280, 119-142. https://doi.org/10.1098/rstb.1977.0102

Sagawa, T., Nagahashi, Y., Satoguchi, Y., Holbourn, A., Itaki, T., Gallagher, S.J., et al. (2018). Integrated tephrostratigraphy and stable isotope stratigraphy in the Japan Sea and East China Sea using IODP Sites U1426, U1427 and U1429, Expedition 346 Asian Monsoon. Progress in Earth and Planetary Science 5(18). https://doi.org/10.1186/s40645-018-0168-7

Saito, Y., Yang, Z., \& Hori, K. (2001). The Huanghe (Yellow River) and Changjiang (Yangtze River) deltas: A review on their characteristics, evolution and sediment discharge during the Holocene. Geomorphology, 41, 219-231. https://doi.org/10.1016/S0169-555X(01)00118-0

Shackleton, N.J. \& Opdyke, N.D. (1976). Oxygen-isotope and paleomagnetic stratigraphy of Pacific core V28-239: Late Pliocene to latest Pleistocene. Geological Society of America Memoir, 145, 449-464. DOI: 10.1130/MEM145p449

Siddall, M., Chappell, J., \& Potter, E.K. (2007). 7. Eustatic sea level during past interglacials. Developments in Quaternary Science, 7, 75-92. https://doi.org/10.1016/S1571-0866(07)80032-7

Spötl, C., Scholz, D., \& Mangini, A. (2008). A terrestrial U/Th-dated stable isotope record of the Penultimate Interglacial. Earth and Planetary Science Letters, 276, 283-292. https://doi.org/10.1016/j.epsl.2008.09.029

Stolz, K. \& Baumann, K.H. (2010). Changes in palaeoceanography and palaeoecology during Marine Isotope Stage (MIS) 5 in the eastern North Atlantic (ODP Site 980) deduced from calcareous nannoplankton observations. Palaeogeography, Palaeoclimatology, Palaeoecology, 292, 295-305. https://doi.org/10.1016/j.palaeo.2010.04.002

Sun, Y., Chen, J., Clemens, S.C., Liu, Q., Ji, J., \& Tada, R. (2006). East Asian monsoon variability over the last seven glacial cycles recorded by a loess sequence from the northwestern Chinese Loess Plateau. Geochemistry, Geophysics, Geosystems, 7(12). https://doi.org/10.1029/2006GC001287 
Tada, R., Murray, R.W., Alvarez Zarikian, C.A., Anderson, W.T., Brace, B.J., et al. (2015). Expedition 346 Summary. Proceedings of the Ocean Drilling Program, 346. doi:10.2204/iodp.proc.346.101.2015

Uehara, K., Saito, Y., \& Hori, K. (2002). Paleotidal regime in the Changjiang (Yangtze) Estuary, the East China Sea, and the Yellow Sea at $6 \mathrm{ka}$ and $10 \mathrm{ka}$ estimated from a numerical model. Marine Geology, 183, 179-192. https://doi.org/10.1016/S0025-3227(01)00255-9

Ujiie', H., Tanaka, Y., \& Ono, T. (1991). Late Quarternary paleoceanographic record from the middle Ryukyu Trench slope, northwest Pacific. Marine Micropaleontology, 18, 115-128. https://doi.org/10.1016/0377-8398(91)90008-T

Ujiié, H., \& Ujiié, Y. (1999). Late Quaternary course changes of the Kuroshio Current in the Ryukyu Arc region, northwestern Pacific Ocean. Marine Micropaleontology, 37(1), 23-40. https://doi.org/10.1016/S0377-8398(99)00010-9

Ujiié, Y., Ujiié, H., Taira, A., Nakamura, T., \& Oguri, K. (2003). Spatial and temporal variability of surface water in the Kuroshio source region, Pacific Ocean, over the past 21,000 years: Evidence from planktonic foraminifera. Marine Micropaleontology, 49(4), 335-364. https://doi.org/10.1016/S03778398(03)00062-8

Waelbroeck, C., Labeyrie, L., Michel, E., Duplessy, J.C., McManus, J.F., Lambeck, K., et al. (2002). Sea-level and deep-water temperature changes derived from benthic foraminifera isotopic records. Quaternary Science Reviews, 21, 295-305. https://doi.org/10.1016/S0277-3791(01)00101-9

Wang, P., Clemens, S., Beaufort, L., Braconnot, P., Ganssen, G., Jian, Z., et al. (2005). Evolution and variability of the Asian Monsoon system: State of the art and outstanding issues. Quaternary Science Reviews, 24, 595-629. https://doi.org/10.1016/j.quascirev.2004.10.002

Wang, Y., Cheng, H., Edwards, R.L., Kong, X., Shao, X., Chen, S., et al. (2008). Millennial- and orbital-scale changes in the East Asian Monsoon over the past 224,000 years. Nature, 451, 1090-1093. https://doi.org/10.1038/nature06692

Weber, M.E., Lantzsch, H., Dekens, P., Das, S.K., Reilly, B.T., Martos, Y.M., et al. (2018). 200,000 years of monsoonal history recorded on the lower Bengal Fan strong response to insolation forcing. Global and Planetary Change, 166, 107119. https://doi.org/10.1016/j.gloplacha.2018.04.003 
Wong, G.T.F., Chao, S.Y., Li, Y.H., \& Shiah, F.K. (2000). The Kuroshio Edge Exchange Processes (KEEP) study - An introduction to hypotheses and highlights.

Continental Shelf Research, 20, 335-347. https://doi.org/10.1016/S02784343(99)00075-8

Xu, X. \& Oda, M. (1999). Surface-water evolution of the eastern East China Sea during the last 36,000 years. Marine Geology, 156(1-4), 285-304.

https://doi.org/10.1016/S0025-3227(98)00183-2

Xu, Z., Li, T., Chang, F., Wan, S., Choi, J., \& Lim, D. (2014). Clay-sized sediment provenance change in the northern Okinawa Trough since $22 \mathrm{kyrBP}$ and its paleoenvironmental implication. Palaeogeography, Palaeoclimatology, Palaeoecology, 339, 236-245. https://doi.org/10.1016/j.palaeo.2014.01.016

Yang, S. \& Ding, Z. (2014). A 249 kyr stack of eight loess grain size records from northern China documenting millennial-scale climate variability. Geochemistry, Geophysics, Geosystems, 15(3), 798-814. https://doi.org/10.1002/2013GC005113

Yu, S.W., Tsai, L.L., Talling, P.J., Lin, A.T., Mii, H.S., Chung, S.H., \& Horng, C.S. (2017). Sea level and climatic controls on turbidite occurrence for the past $26 \mathrm{kyr}$ on the flank of the Gaoping Canyon off SW Taiwan. Marine Geology, 392, 140150. https://doi.org/10.1016/j.margeo.2017.08.011

Yuan, D., Cheng, H., Edwards, R.L., Dykoski, C.A., Kelly, M.J., Zhang, M., et a. (2004). Timing, Duration, and Transitions of the Last Interglacial Asian Monsoon. Science, 304(5670), 575-578. https://doi.org/10.1126/science.1091220

Zhang, W., De Vleeschouwer, D., Shen, J., Zhang, Z., \& Zeng, L. (2018). Orbital time scale records of Asian eolian dust from the Sea of Japan since the early Pliocene. Quaternary Science Reviews, 187, 157-167. https://doi.org/10.1016/j.quascirev.2018.03.004

Zhao, D., Wan, S., Toucanne, S., Clift, P.D., Tada, R., Révillon, S., et al. (2017). Distinct control mechanism of fine-grained sediments from Yellow River and Kyushu supply in the northern Okinawa Trough since the last glacial. Geochemistry, Geophysics, Geosystems, 18(8), 2949-2969. https://doi.org/10.1002/2016GC006764

Zhao, D., Wan, S., Clift, P.D., Tada, R., Huang, J., Yin, X., et al. (2018). Provenance, sea-level and monsoon climate controls on silicate weathering of Yellow River sediment in the northern Okinawa Trough during late last glaciation. Palaeogeography, Palaeoclimatology, Palaeoecology, 490, 227-239. https://doi.org/10.1016/j.palaeo.2017.11.002 


\section{CHAPTER 5: SUMMARY AND CONCLUSIONS}

The East Asian Monsoon (EAM) has a tremendous effect on climate systems within East Asia. Due to differential heating differences between land and sea, the East Asian Summer Monsoon (EASM) brings intense precipitation while the East Asian Winter Monsoon (EAWM) increases aridity and wind strength. The intensity of the EASM and EAWM have varied throughout recent geologic history, but interglacial periods typically have strengthened EASM conditions while glacial periods have intensified EAWM conditions. The EAM system has a direct impact on the shallow marginal seas within East Asian, especially the Japan Sea and East China Sea. The Japan Sea is unique in that it is connected to other seas through shallow, narrow straits. Glacioeustatic sea level fluctuation therefore has a significant control on the current flux into the Japan Sea with input of the Tsushima Warm Current (TWC) and East China Sea Coastal Water (ECSCW) during interglacial periods (Chapter 1). Reduced sea levels during glacial periods, however, nearly isolate the Japan Sea from the East China Sea due to the shallow sill depths of the straits, limiting current flux within the sea.

Results from the current study indicate distinct differences in the paleoceanography of the Japan Sea between glacial and interglacial periods (Chapters 2 \& 3). Depending on the source and volume of the oceanic flux to the Japan Sea, different oceanographic conditions developed, such as nutrient availability, density stratification, and bottom water conditions (Chapter 2). The combination of multiple oceanographic factors led to the deposition of sediment with distinct dark and light color banding, synchronous throughout the Japan Sea. Site U1427 in the Japan Sea lacks these dark and 
light color bands due to its shallow depth $(330 \mathrm{~m})$, but material deposited during interglacial periods typically had higher $\mathrm{CaCO}_{3}$, $\mathrm{TOC}$, and $\mathrm{TN}$ concentrations and enriched $\delta^{13} \mathrm{C}$ values. Glacial sediments, however, had lower concentrations of $\mathrm{CaCO}_{3}$, TOC, and TN and depleted $\delta^{13} \mathrm{C}$ values, indicating that relatively decreased rates of primary productivity occurred in the surface waters, thereby producing less biogenic material. Planktic and benthic foraminiferal assemblages also increase significantly during interglacial periods, corroborating sea level and oceanic flux have a direct impact on productivity rates within the water column. The $\delta^{15} \mathrm{~N}$ values did not follow paleoproductivity levels, likely indicating denitrification in suboxic to anoxic bottom waters.

While Site U1427 was used to determine the impact on sea level, oceanic current flux, and relative primary productivity rates, nearby Site U1426 expanded upon this concept to better understand the role of the Mid-Pleistocene Transition (MPT) 700-1200 ka (Chapter 3). The continuous sedimentary record at Site U14126 was nearly 3 times as long as Sites U1427 and U1429, which allowed for a long-term study on the cyclicity of relative primary productivity preserved within the sediment. Similar to Site U1427, increased concentrations of $\mathrm{CaCO}_{3}, \mathrm{TOC}$, and $\mathrm{TN}$ concentrations and enriched $\delta^{13} \mathrm{C}$ values occurred during interglacial periods, indicating increased primary productivity in the surface waters. The frequency of primary productivity cycles indicated by continuous wavelet and multimethod spectral analysis, however, indicated a significant shift in periodicities at the MPT boundary. Before the MPT, higher frequency orbital signals and their respective heterodynes are dominant in the spectral records while lower frequency $\sim 100$ ky cycles are present after the MPT. Numerous studies have described the effects of 
the MPT in marine sediments, but few records from the Japan Sea have been long enough to establish the periodicity before the MPT. The orbital periods and their respective heterodynes identified indicate a direct relationship between orbital forcing, sea level, oceanic influx, and nutrient concentrations within the Japan Sea.

Unlike the enclosed Japan Sea, the East China Sea has open exchange with several marginal seas and the Pacific Ocean, but glacio-eustatic sea level fluctuation also has a direct impact on oceanographic conditions within the sea (Chapter 4). The East China Sea consists of a shallow ( $<200 \mathrm{~m}$ deep) epicontinental shelf and deep ( $>2000 \mathrm{~m})$ Okinawa Trough system. With significant reductions in sea level during glacial periods, the shoreline regresses farther south, exposing over one-half of the epicontinental shelf. With increased aerial exposure of the shelf, the Yangtze and Yellow Rivers migrated thousands of kilometers from their present location towards the Okinawa Trough. It would therefore be expected that East China Sea sediments would indicate clear differentiation between glacial and interglacial periods. Site U1429, however, has nearly constant concentrations of $\mathrm{CaCO}_{3}, \mathrm{TOC}, \mathrm{TN}$, and $\delta^{13} \mathrm{C}$ values throughout the $\sim 350,000$ year record with the exception of abrupt, short-lived stadial events during interglacial periods.

Stadials during MIS 5.2, MIS 5.4, MIS 7.2 and MIS 7.4 show clear negative excursions from the geochemical records (Chapter 4). Nutrient loads and the resulting primary productivity within the East China Sea are not controlled by the Yangtze and Yellow Rivers, but instead upwelling of the Kuroshio Current throughout the Okinawa Trough. The fluvial discharge into the East China Sea is rich in carbon and nitrogen but deficient in phosphorous, limiting the amount of biogenic material produced near the 
deltas. The Kuroshio Intermediate Water that is upwelled within the Okinawa Trough, however, is phosphorous-rich and therefore has a greater control on the relative rates of primary productivity occurring at Site U1429. The path of the Kuroshio Current during glacial periods has been debated within the scientific community with some claiming that the Kuroshio Current does not enter the East China Sea during glacial low stands and others identifying only a small migration of the Kuroshio within the sea. This study indicates that the Kuroshio Current has had a constant flux in the sea and due to the shelf topography and current flux, constant upwelling conditions have prevailed in the Okinawa Trough. The four stadial events identified at Site U1429 are likely the result of decreased volume of the Kuroshio Current or change in current path and gravity flow deposition, corroborated by grain size and $\mathrm{Ca} / \mathrm{Fe}$ analysis.

The Japan Sea serves as an ideal proxy into past oceanographic conditions in East Asia, specifically the effects of the complex oceanic-atmospheric EAM system. As climate and sea levels vary in the future, having a clear understanding of paleoclimatic and paleoceanographic conditions will allow for a better understanding of future changes in a region that contains nearly one-third of the global population. Changes within the EAM climate system as a result of future climate change will alter the precipitation and humidity patterns within East Asia, likely having a significant effect on water supply within the region. Developing a better understanding of the EAM variability throughout the recent geological past, especially the role of EASM in precipitation and nutrient flux during interglacial periods, will better prepare future generations of scientists to combat climate change within this densely populated region. The complex relationship between orbital forcing, sea level, oceanic current flux, nutrient loads, and primary productivity 
within marginal Asian seas will require additional expeditions, sampling, and interdisciplinary collaborations, but the research of IODP Expedition 346 within the Japan Sea and East China Seas will serve as a significant contribution to the scientific community. 


\section{APPENDIX 1}

Appendix 1: Internal standards analyzed to determine the precision of TOC (\%), TN (\%), $\delta^{13} \mathrm{C}\left(\%\right.$ vs. VPDB), and $\delta^{15} \mathrm{~N}(\%$ vs. AIR) values.

\begin{tabular}{lcccc}
\hline Standard & TOC & TN & $\boldsymbol{\delta}^{\mathbf{1 3}} \mathbf{C}$ & $\boldsymbol{\delta}^{\mathbf{1 5}} \mathbf{N}$ \\
\hline Glycine & 32.00 & 18.66 & -17.94 & 5.57 \\
Citrus leaves (SRM 1524) & 49.69 & 10.31 & $-27.21 \pm 0.07$ & $4.77 \pm 0.13$ \\
Bovine liver (SRM 1577) & 43.22 & 2.74 & $-21.52 \pm 0.17$ & $7.46 \pm 0.08$ \\
Anu sucrose (IAEA-CH-6) & & & $-10.25 \pm 0.05$ & \\
IAEA-N1 & & 21.20 & & $0.4 \pm 0.2$ \\
\hline
\end{tabular}




\section{APPENDIX 2}

Appendix 2. Sample name, corresponding depth (m), age (ky), $\% \mathrm{CaCO}_{3}, \% \mathrm{TOC}, \delta^{13} \mathrm{C}\left(\% \circ \mathrm{vs}\right.$. VPDB), \%TN, and $\delta^{15} \mathrm{~N}(\% \circ$ vs. AIR) for Site U1426.

\begin{tabular}{llllllll}
\hline Sample & Depth (m) & Age & \%CaCO3 & \%TOC & $\boldsymbol{\delta}^{\mathbf{1 3}} \mathbf{C}$ & TN & $\boldsymbol{\delta}^{\mathbf{1 5}} \mathbf{N}$ \\
\hline 1426C-1H-1W-73 & 0.73 & 5.21 & 1.96 & 1.14 & -24.14 & 0.30 & 5.51 \\
1426C-1H-2W-23 & 1.73 & 12.83 & 0.04 & 1.21 & -24.13 & 0.30 & 5.22 \\
1426C-1H-2W-123 & 2.73 & 20.46 & 3.56 & 1.14 & -24.24 & 0.11 & 5.06 \\
1426C-1H-3W-63 & 3.63 & 27.65 & 0.04 & 6.36 & -22.06 & 0.14 & 5.68 \\
1426A-2H-1W-73 & 3.93 & 30.04 & 1.14 & 0.55 & -22.83 & 0.09 & 7.51 \\
1426A-2H-2W-23 & 4.90 & 36.77 & 5.24 & 1.97 & -22.22 & 0.19 & 7.11 \\
1426A-2H-2W-123 & 5.91 & 47.24 & 9.22 & 3.14 & -22.14 & 0.24 & 6.80 \\
1426A-2H-3W-73 & 6.91 & 56.38 & 7.41 & 2.78 & -22.84 & 0.26 & 7.42 \\
1426A-2H-4W-23 & 7.91 & 67.05 & 11.91 & 1.67 & -21.76 & 0.17 & 7.35 \\
1426A-2H-4W-123 & 8.91 & 73.82 & 15.20 & 2.33 & -21.47 & 0.16 & 7.04 \\
1426A-2H-5W-73 & 9.91 & 85.15 & 8.15 & 2.07 & -21.39 & 0.24 & 6.89 \\
1426A-2H-6W-23 & 10.91 & 94.86 & 2.64 & 2.75 & -21.54 & 0.31 & 5.99 \\
1426C-2H-4W-73 & 11.96 & 107.95 & 7.32 & 2.26 & -21.23 & 0.26 & 6.61 \\
1426C-2H-5W-23 & 12.96 & 117.94 & 22.77 & 2.75 & -22.15 & 0.38 & 4.47 \\
1426C-2H-5W-123 & 13.96 & 127.18 & 10.23 & 2.70 & -21.21 & 0.22 & 5.34 \\
1426C-2H-6W-73 & 14.96 & 136.54 & 1.36 & 2.68 & -22.13 & 0.24 & 5.42 \\
1426A-3H-2W-83 & 15.44 & 141.02 & 2.55 & 1.60 & -21.78 & 0.17 & 6.73 \\
1426A-3H-3W-23 & 16.33 & 149.41 & 1.94 & 0.68 & -23.29 & 0.13 & 7.43 \\
1426A-3H-3W-123 & 17.33 & 158.77 & 1.86 & 0.79 & -23.11 & 0.12 & 5.63 \\
1426A-3H-4W-73 & 18.33 & 168.10 & 1.33 & 1.57 & -23.46 & 0.15 & 7.19 \\
\hline
\end{tabular}




\begin{tabular}{|c|c|c|c|c|c|c|c|}
\hline $1426 A-3 H-5 W-23$ & 19.33 & 178.21 & 4.73 & 1.60 & -22.22 & 0.24 & 7.36 \\
\hline 1426A-3H-5W-123 & 20.33 & 188.55 & 2.53 & 1.36 & -22.83 & 0.14 & 7.40 \\
\hline 1426A-3H-6W-73 & 21.37 & 202.36 & 1.21 & 2.84 & -22.09 & 0.27 & 6.05 \\
\hline $1426 C-3 H-3 W-133$ & 21.70 & 205.05 & 2.82 & 2.30 & -21.69 & 0.22 & 6.17 \\
\hline $1426 \mathrm{C}-3 \mathrm{H}-4 \mathrm{~W}-22$ & 22.08 & 207.88 & 0.03 & 2.44 & -21.69 & 0.26 & 5.82 \\
\hline 1426C-3H-4W-122 & 23.08 & 215.31 & 0.00 & 2.87 & -22.00 & 0.33 & 6.33 \\
\hline 1426C-3H-5W-72 & 24.09 & 223.17 & 6.74 & 1.82 & -22.17 & 0.19 & 7.35 \\
\hline 1426C-3H-6W-17 & 25.04 & 231.70 & 4.84 & 1.64 & -22.70 & 0.23 & 7.37 \\
\hline $1426 \mathrm{~A}-4 \mathrm{H}-2 \mathrm{~W}-73$ & 25.63 & 237.05 & 0.11 & 2.33 & -21.92 & 0.26 & 4.53 \\
\hline $1426 \mathrm{~A}-4 \mathrm{H}-3 \mathrm{~W}-23$ & 26.52 & 241.02 & 1.02 & 1.53 & -22.87 & 0.16 & 6.47 \\
\hline $1426 \mathrm{~A}-4 \mathrm{H}-3 \mathrm{~W}-123$ & 27.52 & 253.79 & 9.65 & 1.99 & -23.75 & 0.18 & 5.92 \\
\hline 1426A-4H-4W-73 & 28.43 & 266.96 & 1.57 & 1.1 & -23.87 & 0.12 & 4.65 \\
\hline $1426 \mathrm{~A}-4 \mathrm{H}-5 \mathrm{~W}-23$ & 29.17 & 275.79 & 3.62 & 1.07 & -23.57 & 0.15 & 6.32 \\
\hline 1426A-4H-5W-123 & 30.17 & 287.47 & 0.09 & 4.72 & -22.23 & 0.38 & 5.77 \\
\hline 1426A-4H-6W-73 & 31.08 & 299.10 & 8.18 & 3.21 & -22.64 & 0.28 & 6.13 \\
\hline $1426 \mathrm{C}-5 \mathrm{H}-2 \mathrm{~W}-23$ & 31.72 & 307.28 & 13.50 & 2.78 & -22.40 & 0.22 & 5.91 \\
\hline $1426 \mathrm{C}-5 \mathrm{H}-2 \mathrm{~W}-123$ & 32.72 & 320.08 & 0.05 & 4.28 & -22.70 & 0.37 & 5.04 \\
\hline $1426 \mathrm{C}-5 \mathrm{H}-3 \mathrm{~W}-72$ & 33.69 & 332.73 & 21.35 & 2.35 & -22.04 & 0.16 & 6.11 \\
\hline $1426 \mathrm{C}-5 \mathrm{H}-4 \mathrm{~W}-23$ & 34.65 & 345.45 & 13.42 & 1.84 & -22.28 & 0.16 & 6.26 \\
\hline 1426C-5H-5W-73 & 36.39 & 368.50 & 2.99 & 1.06 & -23.80 & 0.12 & 4.54 \\
\hline $1426 C-5 H-6 W-23$ & 37.35 & 381.22 & 3.41 & 2.61 & -22.27 & 0.23 & 6.19 \\
\hline 1426D-5H-2W-122 & 38.29 & 393.44 & 1.34 & 3.12 & -21.98 & 0.32 & 5.88 \\
\hline 1426D-5H-3W-72 & 39.30 & 404.35 & 7.75 & 3.65 & -22.33 & 0.29 & 5.70 \\
\hline 1426D-5H-4W-22 & 40.30 & 414.31 & 1.78 & 1.96 & -21.57 & 0.22 & 5.59 \\
\hline $1426 \mathrm{D}-5 \mathrm{H}-4 \mathrm{~W}-122$ & 41.30 & 424.27 & 0.01 & 2.11 & -22.34 & 0.21 & 6.02 \\
\hline 1426D-5H-5W-73 & 42.23 & 433.51 & 0.09 & 0.98 & -25.75 & 0.13 & 8.19 \\
\hline
\end{tabular}




\begin{tabular}{|c|c|c|c|c|c|c|c|}
\hline 1426D-5H-6W-22 & 42.82 & 439.41 & 0.98 & 1.44 & -24.62 & 0.14 & 5.92 \\
\hline $1426 \mathrm{~A}-6 \mathrm{H}-8 \mathrm{~W}-23$ & 43.23 & 443.45 & 22.23 & 3.09 & -21.11 & 0.23 & 6.72 \\
\hline 1426D-5H-6W-123 & 43.83 & 449.47 & 1.66 & 1.57 & -23.16 & 0.13 & 5.49 \\
\hline 1426D-5H-7W-63 & 44.73 & 458.44 & 25.86 & 1.12 & -24.1 & 0.08 & 5.55 \\
\hline $1426 \mathrm{C}-6 \mathrm{H}-3 \mathrm{~W}-143$ & 44.82 & 459.31 & 31.62 & 1.15 & -23.34 & 0.09 & 10.46 \\
\hline 1426C-6H-4W-23 & 45.11 & 462.20 & 35.71 & 2.69 & -23.52 & 0.14 & 8.87 \\
\hline $1426 \mathrm{C}-6 \mathrm{H}-5 \mathrm{~W}-73$ & 46.34 & 474.45 & 3.37 & 3.96 & -21.13 & 0.21 & 7.05 \\
\hline $1426 \mathrm{C}-6 \mathrm{H}-6 \mathrm{~W}-23$ & 47.34 & 484.41 & 44.29 & 3.74 & -21.33 & 0.17 & 5.27 \\
\hline 1426C-6H-6W-123 & 48.34 & 494.37 & 2.83 & 3.47 & -21.57 & 0.27 & 5.89 \\
\hline 1426C-6H-7W-53 & 49.05 & 501.44 & 11.82 & 4.55 & -21.57 & 0.33 & 5.92 \\
\hline 1426A-6H-5W-73 & 49.91 & 510.00 & 0.28 & 4.50 & -22.34 & 0.35 & 5.93 \\
\hline $1426 \mathrm{~A}-6 \mathrm{H}-6 \mathrm{~W}-23$ & 50.47 & 515.79 & 0.05 & 4.76 & -22.39 & 0.35 & 4.93 \\
\hline 1426A-6H-7W-73 & 52.36 & 548.20 & 24.51 & 2.65 & -22.40 & 0.24 & 7.16 \\
\hline 1426C-7H-3W-123 & 54.12 & 591.34 & 16.79 & 3.07 & -22.45 & 0.21 & 6.36 \\
\hline 1426C-7H-4W-73 & 55.12 & 612.89 & 18.54 & 2.20 & -21.66 & 0.18 & 6.93 \\
\hline 1426C-7H-5W-23 & 55.66 & 612.89 & 12.54 & 3.19 & -21.72 & 0.24 & 6.66 \\
\hline 1426C-7H-5W-123 & 56.66 & 612.89 & 4.85 & 3.40 & -21.55 & 0.28 & 6.75 \\
\hline 1426C-7H-6W-73 & 57.16 & 612.89 & 20.70 & 2.53 & -21.45 & 0.18 & 5.51 \\
\hline 1426C-7H-7W-23 & 58.61 & 617.03 & 8.15 & 1.86 & -21.66 & 0.18 & 5.82 \\
\hline 1426A-7H-3W-117 & 59.33 & 621.07 & 0.74 & 2.43 & -21.58 & 0.20 & 5.22 \\
\hline 1426A-7H-4W-73 & 60.10 & 626.12 & 0.12 & 1.18 & -25.87 & 0.12 & 3.40 \\
\hline 1426A-7H-5W-23 & 61.01 & 637.58 & 1.41 & 1.47 & -25.31 & 0.12 & 6.38 \\
\hline 1426A-7H-5W-123 & 62.00 & 650.10 & 2.80 & 0.39 & -25.66 & 0.05 & 9.06 \\
\hline 1426A-7H-6W-72 & 63.00 & 662.65 & 13.45 & 1.27 & -22.90 & 0.14 & 6.67 \\
\hline 1426C-8H-3W-123 & 66.17 & 702.71 & 18.70 & 1.85 & -21.96 & 0.15 & 7.33 \\
\hline 1426C-8H-4W-73 & 67.17 & 716.02 & 2.85 & 1.12 & -22.22 & 0.15 & 7.17 \\
\hline
\end{tabular}




\begin{tabular}{|c|c|c|c|c|c|c|c|}
\hline $1426 \mathrm{C}-8 \mathrm{H}-5 \mathrm{~W}-23$ & 68.13 & 731.89 & 5.69 & 2.96 & -21.75 & 0.28 & 5.53 \\
\hline 1426C-8H-5W-123 & 69.14 & 748.58 & 10.10 & 2.54 & -22.67 & 0.25 & 6.49 \\
\hline 1426C-8H-6W-73 & 69.98 & 757.58 & 15.95 & 3.07 & -22.32 & 0.26 & 6.02 \\
\hline $1426 \mathrm{D}-8 \mathrm{H}-2 \mathrm{~W}-123$ & 70.48 & 761.64 & 10.65 & 2.85 & -22.35 & 0.23 & 7.26 \\
\hline 1426D-8H-3W-23 & 70.79 & 764.15 & 6.69 & 2.26 & -22.20 & 0.24 & 6.31 \\
\hline $1426 \mathrm{D}-8 \mathrm{H}-3 \mathrm{~W}-123$ & 71.74 & 771.83 & 4.48 & 2.81 & -21.94 & 0.20 & 8.32 \\
\hline 1426D-8H-4W-73 & 72.60 & 778.76 & 2.84 & 2.70 & -22.18 & 0.24 & 6.61 \\
\hline 1426D-8H-5W-23 & 73.12 & 782.99 & 1.10 & 2.21 & -22.59 & 0.16 & 4.79 \\
\hline 1426D-8H-5W-122 & 74.12 & 791.08 & 12.85 & 2.11 & -23.60 & 0.23 & 7.78 \\
\hline 1426D-8H-6W-73 & 74.88 & 799.74 & 36.42 & 3.82 & -22.82 & 0.18 & 8.11 \\
\hline 1426C-9H-3W-43 & 75.65 & 809.28 & 22.40 & 3.29 & -21.74 & 0.23 & 5.60 \\
\hline 1426C-9H-3W-123 & 76.45 & 819.21 & 9.42 & 3.38 & -21.39 & 0.30 & 6.57 \\
\hline 1426C-9H-4W-77 & 77.39 & 830.88 & 10.08 & 2.86 & -21.85 & 0.2 & 6.51 \\
\hline $1426 C-9 H-5 W-23$ & 78.21 & 841.06 & 16.52 & 1.56 & -21.92 & 0.14 & 7.34 \\
\hline 1426C-9H-5W-123 & 79.21 & 853.47 & 0.00 & 3.14 & -22.32 & 0.27 & 5.95 \\
\hline 1426C-9H-6W-73 & 80.10 & 864.52 & 23.44 & 1.97 & -22.31 & 0.14 & 6.16 \\
\hline 1426C-9H-7W-23 & 81.05 & 876.32 & 15.19 & 1.77 & -22.61 & 0.17 & 6.73 \\
\hline 1426C-9H-7W-123 & 82.05 & 886.54 & 1.85 & 2.37 & -24.47 & 0.22 & 3.33 \\
\hline 1426D-9H-4W-73 & 83.16 & 896.70 & 16.65 & 2.14 & -22.66 & 0.15 & 6.46 \\
\hline 1426D-9H-5W-23 & 84.15 & 905.76 & 9.07 & 2.43 & -21.68 & 0.13 & 9.33 \\
\hline 1426D-9H-5W-123 & 85.16 & 914.99 & 15.56 & 2.94 & -21.98 & 0.14 & 7.51 \\
\hline 1426D-9H-6W-73 & 86.16 & 925.03 & 26.35 & 3.90 & -21.38 & 0.16 & 8.21 \\
\hline 1426D-9H-7W-23 & 87.10 & 934.90 & 20.97 & 2.22 & -22.46 & 0.25 & 6.28 \\
\hline $1426 \mathrm{C}-10 \mathrm{H}-4 \mathrm{~W}-23$ & 87.73 & 941.51 & 0.00 & 3.42 & -22.01 & 0.18 & 5.82 \\
\hline $1426 \mathrm{C}-10 \mathrm{H}-5 \mathrm{~W}-23$ & 89.11 & 956.48 & 7.69 & 2.42 & -21.98 & 0.20 & 7.93 \\
\hline $1426 \mathrm{C}-10 \mathrm{H}-5 \mathrm{~W}-123$ & 90.11 & 965.10 & 22.06 & 1.63 & -21.51 & 0.17 & 7.76 \\
\hline
\end{tabular}




\begin{tabular}{|c|c|c|c|c|c|c|c|}
\hline 1426D-10H-3W-88 & 93.03 & 981.03 & 2.63 & 2.46 & -21.68 & 0.31 & 5.66 \\
\hline 1426D-10H-4W-23 & 93.82 & 987.28 & 10.75 & 2.86 & -21.63 & 0.23 & 5.70 \\
\hline 1426D-10H-4W-123 & 94.82 & 995.19 & 2.61 & 3.74 & -21.14 & 0.36 & 6.06 \\
\hline 1426D-10H-5W-73 & 95.80 & 1002.95 & 2.26 & 4.61 & -21.60 & 0.35 & 5.64 \\
\hline 1426D-10H-6W-23 & 96.79 & 1010.78 & 4.86 & 4.66 & -21.90 & 0.32 & 5.55 \\
\hline 1426D-10H-6W-123 & 97.79 & 1018.69 & 1.64 & 3.17 & -21.90 & 0.24 & 7.26 \\
\hline $1426 \mathrm{C}-11 \mathrm{H}-3 \mathrm{~W}-68$ & 98.04 & 1020.71 & 0.93 & 3.11 & -21.74 & 0.28 & 5.48 \\
\hline $1426 \mathrm{C}-11 \mathrm{H}-4 \mathrm{~W}-23$ & 98.70 & 1025.93 & 0.00 & 3.35 & -20.95 & 0.31 & 5.38 \\
\hline $1426 \mathrm{C}-11 \mathrm{H}-4 \mathrm{~W}-123$ & 99.70 & 1033.84 & 4.85 & 2.66 & -21.85 & 0.20 & 7.74 \\
\hline $1426 \mathrm{C}-11 \mathrm{H}-5 \mathrm{~W}-73$ & 100.70 & 1041.76 & 29.10 & 4.56 & -21.78 & 0.22 & 6.32 \\
\hline $1426 \mathrm{C}-11 \mathrm{H}-6 \mathrm{~W}-23$ & 101.71 & 1049.75 & 16.72 & 1.76 & -21.82 & 0.14 & 7.59 \\
\hline $1426 \mathrm{D}-11 \mathrm{H}-3 \mathrm{~W}-73$ & 103.25 & 1061.93 & 8.90 & 2.12 & -22.00 & 0.36 & 5.96 \\
\hline 1426D-11H-4W-23 & 104.16 & 1069.13 & 1.58 & 5.28 & -22.45 & 0.25 & 6.15 \\
\hline 1426D-11H-5W-73 & 106.16 & 1084.95 & 23.16 & 5.39 & -21.96 & 0.29 & 6.50 \\
\hline 1426D-11H-6W-22 & 107.16 & 1092.84 & 18.54 & 1.66 & -22.82 & 0.32 & 6.14 \\
\hline 1426D-11H-6W-123 & 108.16 & 1100.78 & 4.30 & 4.51 & -21.84 & 0.16 & 9.73 \\
\hline 1426D-11H-7W-73 & 109.16 & 1108.70 & 24.02 & 5.87 & -22.27 & 0.30 & 6.79 \\
\hline $1426 \mathrm{C}-12 \mathrm{H}-3 \mathrm{~W}-43$ & 110.20 & 1116.92 & 28.57 & 2.52 & -23.8 & 0.15 & 7.84 \\
\hline 1426C-12H-4W-73 & 111.99 & 1131.08 & 8.22 & 2.00 & -22.12 & 0.19 & 9.19 \\
\hline $1426 \mathrm{C}-12 \mathrm{H}-5 \mathrm{~W}-23$ & 113.01 & 1139.15 & 13.27 & 2.98 & -20.73 & 0.23 & 6.44 \\
\hline $1426 \mathrm{C}-12 \mathrm{H}-5 \mathrm{~W}-123$ & 114.01 & 1147.06 & 0.85 & 2.69 & -21.66 & 0.24 & 7.47 \\
\hline $1426 \mathrm{C}-12 \mathrm{H}-6 \mathrm{~W}-73$ & 115.02 & 1155.05 & 0.00 & 2.65 & -21.85 & 0.25 & 4.74 \\
\hline $1426 \mathrm{~A}-12 \mathrm{H}-5 \mathrm{~W}-23$ & 115.53 & 1159.09 & 0.03 & 3.00 & -22.62 & 0.29 & 5.29 \\
\hline $1426 \mathrm{~A}-12 \mathrm{H}-5 \mathrm{~W}-123$ & 116.53 & 1167.00 & 0.07 & 4.63 & -22.23 & 0.39 & 5.20 \\
\hline $1426 \mathrm{~A}-12 \mathrm{H}-6 \mathrm{~W}-73$ & 117.45 & 1174.31 & 9.05 & 4.06 & -22.37 & 0.25 & 6.75 \\
\hline $1426 \mathrm{~A}-12 \mathrm{H}-7 \mathrm{~W}-23$ & 118.36 & 1181.48 & 6.83 & 2.7 & -22.73 & 0.25 & 6.57 \\
\hline
\end{tabular}




\begin{tabular}{|c|c|c|c|c|c|c|c|}
\hline $1426 \mathrm{~A}-12 \mathrm{H}-7 \mathrm{~W}-113$ & 119.26 & 1188.60 & 4.87 & 1.91 & -22.69 & 0.20 & 5.56 \\
\hline 1426C-13H-2W-113 & 119.92 & 1193.82 & 1.91 & 2.06 & -20.92 & 0.22 & 5.60 \\
\hline 1426C-13H-3W-73 & 120.73 & 1200.23 & 9.45 & 1.33 & -21.14 & 0.17 & 6.71 \\
\hline $1426 C-13 H-4 W-73$ & 121.89 & 1209.41 & 9.79 & 2.12 & -21.75 & 0.22 & 5.19 \\
\hline $1426 \mathrm{C}-13 \mathrm{H}-5 \mathrm{~W}-23$ & 122.55 & 1214.63 & 3.12 & 2.10 & -22.77 & 0.21 & 7.03 \\
\hline $1426 C-13 H-5 W-123$ & 123.55 & 1222.54 & 6.21 & 1.32 & -23.29 & 0.13 & 6.10 \\
\hline 1426C-13H-6W-73 & 124.55 & 1230.45 & 7.83 & 1.49 & -21.79 & 0.17 & 5.82 \\
\hline $1426 C-13 H-7 W-23$ & 125.55 & 1238.36 & 2.02 & 2.65 & -21.28 & 0.25 & 5.39 \\
\hline 1426A-13H-5W-73 & 127.05 & 1250.20 & 1.08 & 3.66 & -22.43 & 0.21 & 5.71 \\
\hline $1426 A-13 H-6 W-23$ & 128.06 & 1258.22 & 0.05 & 1.75 & -21.87 & 0.31 & 5.66 \\
\hline 1426A-13H-6W-123 & 129.06 & 1266.13 & 9.36 & 2.97 & -21.56 & 0.17 & 5.40 \\
\hline $1426 \mathrm{C}-14 \mathrm{H}-2 \mathrm{~W}-23$ & 129.81 & 1272.07 & 8.31 & 2.87 & -21.01 & 0.22 & 6.92 \\
\hline
\end{tabular}


Appendix 3: Sample name, corresponding depth (m), age (ky), $\% \mathrm{CaCO}_{3}, \% \mathrm{TOC}, \delta^{13} \mathrm{C}\left(\%\right.$ vs. VPDB), \%TN, and $\delta^{15} \mathrm{~N}(\% \circ$ vs. AIR) for Site U1427.

\begin{tabular}{|c|c|c|c|c|c|c|c|}
\hline Sample & Depth (m) & Age & $\% \mathrm{CaCO}_{3}$ & \%TOC & $\delta^{13} \mathrm{C}$ & TN & $\delta^{15} N$ \\
\hline $1427 \mathrm{C}-1 \mathrm{H}-1 \mathrm{~W}-74$ & 0.74 & 2.22 & 5.65 & 4.56 & -19.78 & 0.19 & 7.02 \\
\hline $1427 \mathrm{C}-1 \mathrm{H}-2 \mathrm{~W}-24$ & 1.74 & 5.21 & 4.04 & 2.56 & -21.95 & 0.26 & 6.51 \\
\hline $1427 \mathrm{C}-1 \mathrm{H}-2 \mathrm{~W}-124$ & 2.74 & 8.21 & 8.45 & 2.01 & -21.29 & 0.20 & 8.24 \\
\hline $1427 \mathrm{C}-1 \mathrm{H}-3 \mathrm{~W}-74$ & 3.74 & 11.20 & 6.06 & 2.66 & -21.87 & 0.15 & 8.50 \\
\hline $1427 \mathrm{C}-1 \mathrm{H}-4 \mathrm{~W}-24$ & 4.74 & 14.20 & 2.68 & 1.72 & -22.22 & 0.07 & 10.74 \\
\hline $1427 \mathrm{C}-1 \mathrm{H}-4 \mathrm{~W}-124$ & 5.74 & 17.19 & 1.24 & 0.90 & -22.81 & 0.10 & 7.83 \\
\hline $1427 \mathrm{C}-1 \mathrm{H}-5 \mathrm{~W}-74$ & 6.74 & 19.87 & 0.56 & 0.83 & -23.18 & 0.09 & 3.76 \\
\hline $1427 \mathrm{~B}-2 \mathrm{H}-3 \mathrm{~W}-24$ & 8.10 & 23.36 & 8.80 & 1.92 & -21.78 & 0.15 & 9.86 \\
\hline $1427 \mathrm{~B}-2 \mathrm{H}-3 \mathrm{~W}-124$ & 9.10 & 25.92 & 2.23 & 1.66 & -19.56 & 0.07 & 12.85 \\
\hline 1427B-2H-4W-74 & 10.10 & 28.49 & 2.57 & 0.85 & -20.37 & 0.07 & 13.08 \\
\hline $1427 \mathrm{~B}-2 \mathrm{H}-5 \mathrm{~W}-24$ & 11.10 & 30.96 & 10.10 & 2.04 & -20.14 & 0.15 & 10.02 \\
\hline 1427B-2H-5W-124 & 12.10 & 33.29 & 4.13 & 1.80 & -22.21 & 0.14 & 11.93 \\
\hline $1427 \mathrm{C}-2 \mathrm{H}-3 \mathrm{~W}-74$ & 12.54 & 34.31 & 8.41 & 1.62 & -22.12 & 0.16 & 7.57 \\
\hline $1427 \mathrm{C}-2 \mathrm{H}-4 \mathrm{~W}-24$ & 13.55 & 36.67 & 7.32 & 0.96 & -22.31 & 0.14 & 10.42 \\
\hline $1427 \mathrm{C}-2 \mathrm{H}-4 \mathrm{~W}-125$ & 14.56 & 39.02 & 6.85 & 1.56 & -22.92 & 0.14 & 7.80 \\
\hline $1427 \mathrm{C}-2 \mathrm{H}-5 \mathrm{~W}-74$ & 15.58 & 41.40 & 7.44 & 1.44 & -21.62 & 0.14 & 7.77 \\
\hline $1427 \mathrm{~B}-3 \mathrm{H}-1 \mathrm{~W}-124$ & 16.62 & 43.83 & 2.45 & 2.55 & -22.15 & 0.08 & 6.54 \\
\hline 1427B-3H-2W-74 & 17.62 & 46.16 & 2.98 & 0.77 & -22.50 & 0.14 & 10.24 \\
\hline $1427 \mathrm{~B}-3 \mathrm{H}-3 \mathrm{~W}-24$ & 18.62 & 48.49 & 5.58 & 1.72 & -21.30 & 0.09 & 12.87 \\
\hline $1427 \mathrm{~B}-3 \mathrm{H}-3 \mathrm{~W}-123$ & 19.61 & 50.80 & 6.46 & 1.47 & -22.81 & 0.16 & 10.02 \\
\hline 1427B-3H-4W-74 & 20.57 & 53.03 & 5.14 & 1.38 & -21.67 & 0.11 & 12.16 \\
\hline 1427B-3H-5W-24 & 21.57 & 55.20 & 8.24 & 2.08 & -21.55 & 0.17 & 9.65 \\
\hline $1427 \mathrm{C}-3 \mathrm{H}-3 \mathrm{~W}-124$ & 22.57 & 57.25 & 5.56 & 1.11 & -23.33 & 0.13 & 8.50 \\
\hline
\end{tabular}




\begin{tabular}{|c|c|c|c|c|c|c|c|}
\hline $1427 \mathrm{C}-3 \mathrm{H}-4 \mathrm{~W}-74$ & 23.57 & 59.31 & 6.09 & 1.48 & -21.54 & 0.11 & 11.44 \\
\hline $1427 \mathrm{C}-3 \mathrm{H}-5 \mathrm{~W}-24$ & 24.57 & 61.36 & 8.03 & 1.36 & -21.97 & 0.12 & 12.19 \\
\hline $1427 C-3 H-5 W-124$ & 25.57 & 63.41 & 7.45 & 1.14 & -21.84 & 0.12 & 11.51 \\
\hline $1427 \mathrm{C}-3 \mathrm{H}-6 \mathrm{~W}-74$ & 26.57 & 65.46 & 8.95 & 1.83 & -24.37 & 0.12 & 10.88 \\
\hline $1427 \mathrm{~B}-4 \mathrm{H}-2 \mathrm{~W}-128$ & 27.17 & 66.69 & 8.89 & 1.67 & -22.43 & 0.14 & 11.13 \\
\hline 1427B-4H-3W-74 & 28.13 & 68.66 & 11.49 & 1.69 & -21.62 & 0.11 & 11.32 \\
\hline 1427B-4H-4W-24 & 29.12 & 70.69 & 14.62 & 1.60 & -21.48 & 0.17 & 10.17 \\
\hline $1427 \mathrm{~B}-4 \mathrm{H}-4 \mathrm{~W}-124$ & 30.12 & 72.75 & 17.56 & 0.67 & -21.54 & 0.14 & 10.28 \\
\hline 1427B-4H-5W-74 & 31.11 & 74.78 & 15.38 & 2.02 & -21.28 & 0.16 & 9.56 \\
\hline $1427 \mathrm{C}-4 \mathrm{H}-3 \mathrm{~W}-74$ & 31.40 & 75.37 & 13.72 & 2.14 & -20.86 & 0.16 & 9.15 \\
\hline $1427 \mathrm{C}-4 \mathrm{H}-4 \mathrm{~W}-24$ & 32.40 & 77.42 & 12.55 & 2.59 & -21.11 & 0.17 & 8.46 \\
\hline $1427 \mathrm{C}-4 \mathrm{H}-4 \mathrm{~W}-124$ & 33.40 & 79.48 & 22.99 & 2.36 & -21.06 & 0.18 & 7.80 \\
\hline $1427 \mathrm{C}-4 \mathrm{H}-5 \mathrm{~W}-74$ & 34.30 & 81.32 & 16.28 & 2.53 & -21.36 & 0.16 & 7.20 \\
\hline $1427 \mathrm{C}-4 \mathrm{H}-6 \mathrm{~W}-24$ & 35.26 & 83.29 & 9.42 & 2.46 & -20.77 & 0.18 & 8.54 \\
\hline $1427 \mathrm{~B}-5 \mathrm{H}-2 \mathrm{~W}-74$ & 36.90 & 86.12 & 8.89 & 2.27 & -21.85 & 0.19 & 8.72 \\
\hline 1427B-5H-3W-24 & 37.90 & 88.71 & 15.43 & 2.37 & -21.61 & 0.19 & 8.05 \\
\hline 1427B-5H-3W-124 & 38.90 & 93.47 & 15.69 & 2.65 & -21.60 & 0.23 & 8.90 \\
\hline 1427B-5H-4W-74 & 39.74 & 97.47 & 18.92 & 1.66 & -20.98 & 0.21 & 7.57 \\
\hline 1427B-5H-5W-24 & 40.74 & 102.23 & 10.50 & 3.03 & -21.27 & 0.19 & 7.60 \\
\hline 1427B-5H-5W-124 & 41.74 & 106.99 & 13.16 & 2.52 & -21.40 & 0.19 & 7.66 \\
\hline $1427 C-5 H-3 W-24$ & 42.34 & 109.84 & 10.52 & 2.49 & -21.10 & 0.15 & 8.12 \\
\hline $1427 C-5 H-3 W-124$ & 43.34 & 114.60 & 11.95 & 2.18 & -21.03 & 0.16 & 7.34 \\
\hline $1427 \mathrm{C}-5 \mathrm{H}-4 \mathrm{~W}-74$ & 44.17 & 118.55 & 13.69 & 2.40 & -21.74 & 0.16 & 6.96 \\
\hline $1427 C-5 H-5 W-24$ & 44.88 & 121.93 & 8.61 & 1.49 & -21.91 & 0.13 & 7.87 \\
\hline $1427 C-5 H-5 W-124$ & 45.88 & 125.32 & 2.69 & 1.41 & -21.47 & 0.14 & 8.96 \\
\hline 1427C-5H-6W-74 & 46.67 & 127.69 & 0.43 & 1.59 & -22.31 & 0.11 & 9.12 \\
\hline $1427 \mathrm{~B}-6 \mathrm{H}-2 \mathrm{~W}-124$ & 47.96 & 131.55 & 0.06 & 1.15 & -24.48 & 0.13 & 7.12 \\
\hline
\end{tabular}




\begin{tabular}{|c|c|c|c|c|c|c|c|}
\hline 1427B-6H-3W-74 & 48.80 & 134.07 & 2.85 & 1.26 & -21.56 & 0.08 & 12.24 \\
\hline 1427B-6H-4W-24 & 49.80 & 137.06 & 0.94 & 0.82 & -23.90 & 0.10 & 9.37 \\
\hline 1427B-6H-4W-124 & 50.80 & 140.04 & 4.42 & 0.88 & -24.03 & 0.11 & 8.59 \\
\hline 1427B-6H-5W-74 & 51.80 & 142.17 & 0.00 & 0.79 & -23.70 & 0.10 & 11.03 \\
\hline $1427 \mathrm{C}-6 \mathrm{H}-3 \mathrm{~W}-96$ & 52.57 & 143.80 & 0.18 & 1.61 & -23.71 & 0.09 & 10.96 \\
\hline $1427 \mathrm{C}-6 \mathrm{H}-4 \mathrm{~W}-74$ & 53.57 & 145.93 & 1.24 & 0.65 & -22.48 & 0.09 & 12.24 \\
\hline $1427 \mathrm{C}-6 \mathrm{H}-5 \mathrm{~W}-24$ & 54.11 & 147.08 & 1.52 & 0.55 & -23.59 & 0.09 & 7.67 \\
\hline $1427 \mathrm{C}-6 \mathrm{H}-5 \mathrm{~W}-124$ & 55.11 & 149.20 & 1.47 & 0.66 & -23.3 & 0.09 & 12.58 \\
\hline $1427 \mathrm{~B}-8 \mathrm{H}-2 \mathrm{~W}-124$ & 55.75 & 150.56 & 2.35 & 0.64 & -20.83 & 0.10 & 10.83 \\
\hline 1427C-6H-6W-74 & 56.07 & 151.24 & 0.35 & 0.72 & -23.78 & 0.1 & 5.86 \\
\hline 1427B-8H-2W-48 & 56.49 & 152.13 & 2.86 & 0.73 & -21.67 & 0.09 & 11.34 \\
\hline 1427B-8H-3W-74 & 58.25 & 156.35 & 2.46 & 0.99 & -22.37 & 0.09 & 11.49 \\
\hline 1427B-8H-4W-24 & 59.25 & 159.64 & 4.58 & 0.86 & -22.53 & 0.10 & 11.47 \\
\hline $1427 \mathrm{~B}-8 \mathrm{H}-4 \mathrm{~W}-124$ & 60.25 & 162.94 & 7.26 & 1.12 & -22.27 & 0.11 & 11.71 \\
\hline 1427B-8H-6W-24 & 62.25 & 169.52 & 10.49 & 1.01 & -22.27 & 0.13 & 10.53 \\
\hline 1427C-7H-4W-74 & 62.54 & 170.48 & 9.63 & 1.21 & -22.26 & 0.17 & 11.42 \\
\hline $1427 \mathrm{C}-7 \mathrm{H}-5 \mathrm{~W}-24$ & 63.11 & 172.36 & 12.10 & 1.83 & -21.66 & 0.13 & 11.09 \\
\hline $1427 \mathrm{C}-7 \mathrm{H}-5 \mathrm{~W}-124$ & 64.11 & 175.65 & 5.85 & 1.41 & -21.44 & 0.17 & 8.70 \\
\hline 1427C-7H-6W-74 & 65.01 & 178.61 & 4.32 & 1.30 & -21.71 & 0.16 & 10.14 \\
\hline $1427 \mathrm{C}-7 \mathrm{H}-7 \mathrm{~W}-24$ & 65.95 & 181.71 & 3.97 & 1.18 & -22.13 & 0.15 & 11.46 \\
\hline 1427B-9H-2W-118 & 67.11 & 185.53 & 4.14 & 1.31 & -21.6 & 0.12 & 11.56 \\
\hline 1427B-9H-3W-74 & 67.89 & 188.10 & 4.19 & 4.95 & -22.52 & 0.11 & 11.03 \\
\hline 1427B-9H-4W-24 & 68.86 & 191.29 & 5.52 & 1.36 & -21.25 & 0.16 & 10.74 \\
\hline 1427B-9H-4W-116 & 69.78 & 194.32 & 3.91 & 1.78 & -21.71 & 0.16 & 9.96 \\
\hline 1427B-9H-5W-74 & 70.58 & 196.96 & 3.89 & 1.44 & -21.83 & 0.15 & 10.36 \\
\hline $1427 \mathrm{C}-8 \mathrm{H}-4 \mathrm{~W}-24$ & 73.43 & 206.34 & 5.10 & 0.67 & -22.02 & 0.16 & 10.84 \\
\hline $1427 \mathrm{C}-8 \mathrm{H}-4 \mathrm{~W}-124$ & 74.43 & 209.64 & 4.12 & 1.49 & -20.88 & 0.16 & 10.67 \\
\hline
\end{tabular}




\begin{tabular}{|c|c|c|c|c|c|c|c|}
\hline $1427 \mathrm{C}-8 \mathrm{H}-5 \mathrm{~W}-74$ & 75.43 & 212.93 & 8.46 & 1.71 & -21.45 & 0.18 & 9.35 \\
\hline $1427 \mathrm{C}-8 \mathrm{H}-6 \mathrm{~W}-24$ & 76.43 & 216.22 & 8.34 & 1.37 & -20.63 & 0.16 & 8.52 \\
\hline 1427C-8H-6W-124 & 77.43 & 219.39 & 3.39 & 1.78 & -20.74 & 0.20 & 8.84 \\
\hline 1427C-8H-7W-24 & 77.91 & 220.89 & 3.67 & 1.65 & -21.98 & 0.15 & 9.96 \\
\hline 1427B-10H-2W-124 & 78.29 & 222.07 & 4.43 & 1.40 & -22.14 & 0.18 & 9.58 \\
\hline 1427B-10H-3W-74 & 79.26 & 225.10 & 8.91 & 1.57 & -22.64 & 0.16 & 8.76 \\
\hline 1427B-10H-4W-124 & 81.21 & 231.19 & 7.97 & 1.92 & -21.64 & 0.17 & 9.06 \\
\hline 1427B-10H-5W-74 & 82.21 & 234.32 & 8.88 & 1.65 & -21.82 & 0.14 & 9.31 \\
\hline 1427B-10H-6W-24 & 83.21 & 237.44 & 3.24 & 1.62 & -21.96 & 0.16 & 9.78 \\
\hline 1427C-9H-3W-118 & 84.07 & 240.13 & 0.67 & 1.47 & -23.21 & 0.18 & 8.02 \\
\hline 1427C-9H-4W-74 & 85.13 & 243.20 & 4.08 & 1.99 & -21.40 & 0.16 & 8.88 \\
\hline $1427 \mathrm{C}-9 \mathrm{H}-5 \mathrm{~W}-24$ & 86.14 & 245.83 & 2.69 & 1.30 & -22.94 & 0.14 & 9.92 \\
\hline 1427C-9H-6W-74 & 87.89 & 250.39 & 4.10 & 1.52 & -22.31 & 0.10 & 11.34 \\
\hline 1427B-11H-2W-24 & 88.33 & 251.53 & 3.77 & 1.33 & -24.77 & 0.18 & 8.89 \\
\hline 1427B-11H-3W-74 & 89.95 & 254.86 & 4.22 & 1.17 & -22.24 & 0.12 & 10.74 \\
\hline 1427B-11H-4W-24 & 90.95 & 256.84 & 4.45 & 1.05 & -22.78 & 0.12 & 10.38 \\
\hline 1427B-11H-4W-124 & 91.95 & 258.83 & 3.00 & 1.17 & -22.56 & 0.13 & 10.68 \\
\hline 1427B-11H-5W-74 & 92.95 & 260.81 & 8.04 & 1.17 & -22.95 & 0.13 & 10.04 \\
\hline $1427 \mathrm{C}-10 \mathrm{H}-2 \mathrm{~W}-124$ & 93.03 & 260.97 & 2.42 & 0.78 & -20.65 & 0.12 & 11.01 \\
\hline 1427C-10H-3W-74 & 93.84 & 262.58 & 2.10 & 0.77 & -20.87 & 0.09 & 12.60 \\
\hline $1427 \mathrm{C}-10 \mathrm{H}-4 \mathrm{~W}-24$ & 94.67 & 264.23 & 2.03 & 0.75 & -21.05 & 0.10 & 11.81 \\
\hline $1427 \mathrm{C}-10 \mathrm{H}-4 \mathrm{~W}-124$ & 95.67 & 266.21 & 2.25 & 0.74 & -22.35 & 0.09 & 12.70 \\
\hline 1427C-10H-5W-74 & 96.61 & 268.08 & 3.09 & 2.08 & -21.34 & 0.10 & 12.31 \\
\hline $1427 \mathrm{C}-10 \mathrm{H}-6 \mathrm{~W}-36$ & 97.74 & 270.28 & 7.92 & 0.72 & -23.71 & 0.11 & 9.07 \\
\hline 1427B-12H-2W-24 & 98.41 & 271.19 & 11.53 & 0.98 & -23.53 & 0.13 & 11.13 \\
\hline $1427 \mathrm{~B}-12 \mathrm{H}-2 \mathrm{~W}-124$ & 99.41 & 272.55 & 9.59 & 1.22 & -22.31 & 0.13 & 10.55 \\
\hline $1427 \mathrm{~B}-12 \mathrm{H}-3 \mathrm{~W}-74$ & 100.28 & 273.74 & 5.33 & 0.87 & -23.55 & 0.20 & 8.96 \\
\hline
\end{tabular}




\begin{tabular}{|c|c|c|c|c|c|c|c|}
\hline 1427B-12H-4W-24 & 101.13 & 274.90 & 11.40 & 0.86 & -24.39 & 0.11 & 11.87 \\
\hline $142712 \mathrm{H}-4 \mathrm{~W}-124$ & 102.13 & 276.26 & 10.37 & 1.18 & -23.10 & 0.15 & 10.19 \\
\hline $1427 \mathrm{~B}-12 \mathrm{H}-5 \mathrm{~W}-74$ & 103.00 & 277.44 & 6.23 & 0.97 & -23.35 & 0.14 & 10.69 \\
\hline 1427B-12H-6W-124 & 105.00 & 280.16 & 7.07 & 2.37 & -21.29 & 0.12 & 11.34 \\
\hline 1427B-12H-7W-74 & 106.00 & 281.52 & 11.23 & 1.31 & -22.46 & 0.12 & 11.25 \\
\hline $1427 \mathrm{C}-12 \mathrm{H}-1 \mathrm{~W}-74$ & 106.37 & 282.03 & 2.91 & 1.93 & -22.03 & 0.18 & 8.87 \\
\hline $1427 \mathrm{C}-12 \mathrm{H}-2 \mathrm{~W}-24$ & 107.37 & 283.39 & 13.77 & 2.65 & -21.11 & 0.22 & 7.37 \\
\hline $1427 \mathrm{C}-12 \mathrm{H}-2 \mathrm{~W}-124$ & 108.37 & 284.75 & 11.68 & 2.46 & -21.13 & 0.20 & 7.83 \\
\hline $1427 \mathrm{C}-12 \mathrm{H}-3 \mathrm{~W}-74$ & 109.31 & 287.61 & 9.75 & 1.91 & -21.21 & 0.19 & 8.34 \\
\hline $1427 \mathrm{C}-12 \mathrm{H}-4 \mathrm{~W}-24$ & 110.31 & 291.07 & 9.21 & 2.54 & -22.30 & 0.18 & 9.39 \\
\hline $1427 \mathrm{C}-12 \mathrm{H}-4 \mathrm{~W}-124$ & 111.31 & 294.53 & 10.70 & 2.40 & -20.97 & 0.18 & 8.53 \\
\hline $1427 \mathrm{C}-12 \mathrm{H}-5 \mathrm{~W}-68$ & 112.25 & 297.78 & 18.16 & 1.98 & -21.56 & 0.17 & 8.92 \\
\hline 1427B-14H-3W-24 & 112.49 & 298.61 & 12.04 & 2.03 & -21.53 & 0.17 & 9.54 \\
\hline 1427B-14H-3W-124 & 113.49 & 302.07 & 14.46 & 1.89 & -21.68 & 0.20 & 8.99 \\
\hline 1427B-14H-4W-74 & 114.49 & 305.53 & 15.51 & 2.25 & -21.74 & 0.17 & 9.79 \\
\hline 1427B-14H-5W-24 & 115.45 & 308.85 & 12.95 & 2.67 & -21.65 & 0.14 & 7.68 \\
\hline 1427B-14H-5W-125 & 116.46 & 312.35 & 0.58 & 1.80 & -21.69 & 0.18 & 9.75 \\
\hline $1427 \mathrm{C}-13 \mathrm{H}-1 \mathrm{~W}-124$ & 117.72 & 316.71 & 10.79 & 2.39 & -21.50 & 0.18 & 8.19 \\
\hline $1427 \mathrm{C}-13 \mathrm{H}-2 \mathrm{~W}-74$ & 118.70 & 320.10 & 19.78 & 2.36 & -21.41 & 0.17 & 7.42 \\
\hline $1427 \mathrm{C}-13 \mathrm{H}-3 \mathrm{~W}-24$ & 119.58 & 323.14 & 19.69 & 2.36 & -21.96 & 0.17 & 8.30 \\
\hline $1427 \mathrm{C}-13 \mathrm{H}-3 \mathrm{~W}-124$ & 120.58 & 326.60 & 1.14 & 1.13 & -22.22 & 0.10 & 9.35 \\
\hline 1427C-13H-4W-74 & 121.55 & 329.52 & 0.44 & 1.55 & -21.92 & 0.13 & 8.66 \\
\hline $1427 \mathrm{C}-13 \mathrm{H}-5 \mathrm{~W}-24$ & 122.40 & 331.10 & 1.48 & 1.78 & -23.23 & 0.19 & 7.79 \\
\hline $1427 \mathrm{C}-13 \mathrm{H}-5 \mathrm{~W}-124$ & 123.40 & 332.97 & 2.53 & 1.20 & -24.18 & 0.14 & 8.67 \\
\hline 1427B-15H-5W-24 & 125.01 & 335.97 & 0.78 & 1.24 & -24.65 & 0.04 & 6.42 \\
\hline 1427B-15H-5W-124 & 126.01 & 337.84 & 0.04 & 1.08 & -24.75 & 0.16 & 7.38 \\
\hline 1427B-15H-6W-44 & 126.71 & 339.14 & 0.28 & 0.16 & -25.33 & & \\
\hline
\end{tabular}




\begin{tabular}{llllllll}
\hline $1427 \mathrm{C}-14 \mathrm{H}-2 \mathrm{~W}-124$ & 129.54 & 344.43 & 3.23 & 0.80 & -24.14 & 0.12 & 9.93 \\
$1427 \mathrm{C}-14 \mathrm{H}-3 \mathrm{~W}-74$ & 130.41 & 346.05 & 2.43 & 0.85 & -23.99 & 0.10 & 11.08 \\
$1427-14 \mathrm{H}-4 \mathrm{~W}-24$ & 131.30 & 346.48 & 4.12 & 0.92 & -24.06 & 0.11 & 9.87 \\
$1427-14 \mathrm{H}-4 \mathrm{~W}-124$ & 132.30 & & 2.71 & 1.79 & -21.72 & 0.11 & 10.31
\end{tabular}




\section{APPENDIX 4}

Appendix 4: Sample name, corresponding depth (m), age (ky), \%CaCO $3, \% \mathrm{TOC}, \delta^{13} \mathrm{C}, \% \mathrm{TN}$, and $\delta^{15} \mathrm{~N}$ for Site U1429.

\begin{tabular}{|c|c|c|c|c|c|c|c|}
\hline Sample & Depth (m) & Age & $\% \mathrm{CaCO}_{3}$ & \%TOC & $\delta^{13} \mathrm{C}$ & $\mathrm{TN}$ & $\delta^{15} \mathrm{~N}$ \\
\hline $1429 \mathrm{~A}-1 \mathrm{H}-1 \mathrm{~W}-7$ & 0.07 & 0.17 & 21.54 & 2.85 & -20.64 & 0.24 & 4.63 \\
\hline $1429 \mathrm{~A}-1 \mathrm{H}-1 \mathrm{~W}-57$ & 0.57 & 1.39 & 22.14 & 2.50 & -20.83 & 0.19 & 5.35 \\
\hline $1429 \mathrm{~A}-1 \mathrm{H}-1 \mathrm{~W}-107$ & 1.07 & 2.62 & 21.49 & 2.58 & -21.39 & 0.18 & 5.60 \\
\hline $1429 \mathrm{~A}-1 \mathrm{H}-1 \mathrm{~W}-147$ & 1.47 & 3.60 & 18.94 & 1.97 & -21.23 & 0.15 & 6.00 \\
\hline $1429 \mathrm{~A}-1 \mathrm{H}-2 \mathrm{~W}-57$ & 2.07 & 5.08 & 3.58 & 0.51 & -21.92 & 0.24 & 5.19 \\
\hline $1429 \mathrm{~A}-1 \mathrm{H}-2 \mathrm{~W}-107$ & 2.57 & 6.31 & 2.58 & 0.39 & -22.68 & 0.20 & 5.45 \\
\hline $1429 \mathrm{~A}-1 \mathrm{H}-2 \mathrm{~W}-108$ & 2.57 & 6.32 & 3.21 & 0.40 & -23.33 & 0.02 & 1.20 \\
\hline $1429 \mathrm{~A}-1 \mathrm{H}-2 \mathrm{~W}-147$ & 2.97 & 7.30 & 18.79 & 1.81 & -21.12 & 0.14 & 5.98 \\
\hline $1429 A-1 H-4 W-57$ & 3.57 & 8.38 & 12.57 & 1.87 & -21.25 & 0.15 & 6.44 \\
\hline $1429 \mathrm{~B}-2 \mathrm{H}-2 \mathrm{~W}-107$ & 5.41 & 11.68 & 9.21 & 2.75 & -21.18 & 0.13 & 7.20 \\
\hline $1429 \mathrm{~B}-2 \mathrm{H}-2 \mathrm{~W}-147$ & 5.80 & 12.38 & 14.34 & 1.25 & -20.95 & 0.20 & 7.48 \\
\hline 1429B-2H-3W-57 & 6.38 & 13.37 & 14.94 & 2.49 & -21.02 & 0.19 & 6.38 \\
\hline 1429B-2H-3W-107 & 6.87 & 14.12 & 12.12 & 1.67 & -21.07 & 0.16 & 6.01 \\
\hline $1429 \mathrm{~B}-2 \mathrm{H}-3 \mathrm{~W}-147$ & 7.36 & 14.87 & 11.43 & 1.86 & -21.02 & 0.15 & 5.78 \\
\hline 1429B-2H-4W-57 & 7.85 & 15.62 & 9.98 & 1.50 & -21.21 & 0.15 & 6.69 \\
\hline 1429B-2H-4W-107 & 8.33 & 16.36 & 9.75 & 1.59 & -20.68 & 0.15 & 5.69 \\
\hline $1429 \mathrm{~A}-2 \mathrm{H}-2 \mathrm{~W}-107$ & 8.97 & 17.34 & 9.38 & 1.64 & -21.33 & 0.14 & 6.54 \\
\hline $1429 \mathrm{~A}-2 \mathrm{H}-3 \mathrm{~W}-8$ & 9.48 & 18.11 & 9.73 & 1.59 & -20.89 & 0.14 & 4.41 \\
\hline $1429 A-2 H-3 W-57$ & 9.97 & 18.79 & 9.98 & 1.69 & -21.20 & 0.15 & 6.92 \\
\hline $1429 \mathrm{~A}-2 \mathrm{H}-3 \mathrm{~W}-107$ & 10.97 & 20.18 & 10.22 & 1.64 & -21.37 & 0.14 & 6.65 \\
\hline $1429 \mathrm{~A}-2 \mathrm{H}-3 \mathrm{~W}-108$ & 10.97 & 20.18 & 10.22 & 1.52 & -20.95 & 0.12 & 3.99 \\
\hline $1429 \mathrm{~A}-2 \mathrm{H}-3 \mathrm{~W}-147$ & 11.37 & 20.73 & 10.56 & 1.70 & -21.38 & 0.20 & 5.40 \\
\hline $1429 \mathrm{~A}-2 \mathrm{H}-4 \mathrm{~W}-57$ & 11.97 & 21.56 & 10.96 & 1.53 & -20.87 & 0.14 & 6.39 \\
\hline
\end{tabular}




\begin{tabular}{|c|c|c|c|c|c|c|c|}
\hline $1429 \mathrm{~A}-2 \mathrm{H}-4 \mathrm{~W}-107$ & 12.47 & 22.25 & 11.46 & 1.80 & -21.39 & 0.15 & 6.42 \\
\hline $1429 \mathrm{~A}-2 \mathrm{H}-4 \mathrm{~W}-108$ & 12.47 & 22.26 & 12.52 & 1.77 & -21.11 & 0.14 & 4.47 \\
\hline $1429 \mathrm{~A}-2 \mathrm{H}-4 \mathrm{~W}-147$ & 12.87 & 22.81 & 11.65 & 1.71 & -20.83 & 0.16 & 6.42 \\
\hline 1429A-2H-5W-8 & 12.98 & 22.96 & 11.38 & 1.79 & -20.96 & 0.15 & 4.91 \\
\hline $1429 \mathrm{~A}-2 \mathrm{H}-5 \mathrm{~W}-107$ & 13.97 & 24.33 & 12.69 & 2.03 & -20.96 & 0.17 & 6.16 \\
\hline $1429 A-2 H-5 W-108$ & 13.98 & 24.35 & 12.54 & 2.02 & -20.79 & 0.16 & 5.66 \\
\hline 1429A-2H-5W-147 & 14.37 & 24.89 & 13.53 & 1.92 & -20.65 & 0.17 & 6.21 \\
\hline 1429B-3H-2W-107 & 14.86 & 25.56 & 13.17 & 1.66 & -20.55 & 0.16 & 5.65 \\
\hline 1429A-2H-6W-57 & 14.97 & 25.72 & 12.72 & 1.76 & -20.56 & 0.16 & 6.22 \\
\hline $1429 \mathrm{~A}-2 \mathrm{H}-6 \mathrm{~W}-107$ & 15.47 & 26.41 & 12.70 & 1.83 & -20.50 & 0.16 & 6.02 \\
\hline $1429 \mathrm{~A}-2 \mathrm{H}-6 \mathrm{~W}-147$ & 15.87 & 26.97 & 12.56 & 1.85 & -20.69 & 0.16 & 6.07 \\
\hline 1429B-3H-3W-8 & 15.29 & 26.16 & 15.20 & 1.87 & -20.64 & 0.15 & 4.35 \\
\hline 1429B-3H-3W-107 & 16.28 & 27.53 & 14.13 & 1.65 & -20.46 & 0.15 & 6.63 \\
\hline 1429B-3H-3W-108 & 16.29 & 27.55 & 14.15 & 1.69 & -20.94 & 0.14 & 6.59 \\
\hline 1429B-3H-3W-147 & 16.68 & 28.08 & 12.45 & 1.14 & -21.17 & 0.10 & 5.49 \\
\hline $1429 A-3 H-2 W-8$ & 17.48 & 29.20 & 14.28 & 1.67 & -20.45 & 0.14 & 6.29 \\
\hline $1429 A-3 H-2 W-57$ & 17.97 & 29.88 & 13.43 & 1.89 & -20.26 & 0.16 & 5.88 \\
\hline $1429 \mathrm{~A}-3 \mathrm{H}-2 \mathrm{~W}-107$ & 18.47 & 30.96 & 15.54 & 2.19 & -20.30 & 0.17 & 6.06 \\
\hline $1429 A-3 H-2 W-108$ & 18.48 & 30.98 & 10.53 & 2.01 & -20.42 & 0.15 & 8.25 \\
\hline $1429 \mathrm{~A}-3 \mathrm{H}-2 \mathrm{~W}-147$ & 18.47 & 30.96 & 13.05 & 2.06 & -20.18 & 0.17 & 5.93 \\
\hline $1429 \mathrm{~A}-3 \mathrm{H}-3 \mathrm{~W}-57$ & 19.07 & 32.36 & 13.72 & 1.99 & -20.29 & 0.17 & 5.95 \\
\hline $1429 A-3 H-3 W-107$ & 19.57 & 33.53 & 11.97 & 1.60 & -20.57 & 0.15 & 6.25 \\
\hline $1429 A-3 H-3 W-108$ & 19.58 & 33.56 & 13.37 & 1.76 & -21.15 & 0.14 & 4.98 \\
\hline $1429 A-3 H-3 W-147$ & 19.97 & 34.47 & 12.25 & 2.04 & -20.35 & 0.17 & 5.97 \\
\hline 1429A-3H-4W-8 & 20.08 & 34.73 & 13.03 & 2.06 & -20.53 & 0.17 & 4.95 \\
\hline 1429A-3H-4W-57 & 20.57 & 35.87 & 9.42 & 2.02 & -20.51 & 0.18 & 6.42 \\
\hline $1429 A-3 H-4 W-107$ & 21.07 & 37.04 & 9.98 & 1.63 & -20.70 & 0.15 & 6.27 \\
\hline $1429 \mathrm{~A}-3 \mathrm{H}-4 \mathrm{~W}-108$ & 21.08 & 37.06 & 10.02 & 1.69 & -21.10 & 0.13 & 3.26 \\
\hline
\end{tabular}




\begin{tabular}{|c|c|c|c|c|c|c|c|}
\hline $1429 \mathrm{~A}-3 \mathrm{H}-4 \mathrm{~W}-147$ & 21.47 & 37.98 & 10.64 & 1.59 & -21.00 & 0.15 & 6.35 \\
\hline $1429 A-3 H-5 W-57$ & 22.07 & 38.65 & 12.81 & 2.03 & -20.38 & 0.17 & 5.95 \\
\hline 1429A-3H-5W-107 & 22.57 & 39.20 & 12.40 & 1.94 & -20.43 & 0.17 & 5.90 \\
\hline 1429A-3H-5W-108 & 22.58 & 39.21 & 12.30 & 1.87 & -20.48 & 0.16 & 4.42 \\
\hline $1429 A-3 H-5 W-147$ & 22.97 & 39.64 & 12.08 & 1.87 & -20.5 & 0.16 & 5.92 \\
\hline 1429A-3H-6W-8 & 23.08 & 39.76 & 13.14 & 1.80 & -21.10 & 0.15 & 5.01 \\
\hline 1429A-3H-6W-57 & 23.57 & 40.30 & 12.29 & 1.95 & -20.39 & 0.17 & 5.76 \\
\hline 1429A-3H-6W-107 & 24.07 & 40.85 & 11.68 & 1.78 & -20.35 & 0.15 & 6.06 \\
\hline 1429B-4H-2W-107 & 24.34 & 41.14 & 11.85 & 1.76 & -20.40 & 0.16 & 5.26 \\
\hline 1429B-4H-2W-147 & 24.71 & 41.55 & 11.04 & 1.96 & -20.24 & 0.17 & 6.60 \\
\hline 1429B-4H-3W-107 & 25.76 & 42.70 & 13.47 & 1.93 & -20.40 & 0.15 & 5.45 \\
\hline 1429B-4H-3W-147 & 26.13 & 43.11 & 8.59 & 1.57 & -20.55 & 0.17 & 5.68 \\
\hline 1429B-4H-4W-57 & 26.70 & 43.74 & 14.51 & 1.85 & -20.17 & 0.17 & 5.68 \\
\hline 1429B-4H-4W-107 & 27.18 & 44.26 & 10.27 & 1.77 & -20.43 & 0.15 & 5.45 \\
\hline 1429B-4H-5W-57 & 28.12 & 45.41 & 16.26 & 1.0 & -21.20 & 0.10 & 8.10 \\
\hline 1429B-4H-5W-147 & 28.98 & 46.68 & 18.68 & 1.1 & -20.97 & 0.10 & 9.26 \\
\hline 1429B-4H-6W-57 & 29.52 & 47.49 & 18.12 & 1.1 & -21.00 & 0.10 & 10.28 \\
\hline 1429B-4H-6W-107 & 30.02 & 48.24 & 20.55 & 1.2 & -20.77 & 0.11 & 7.89 \\
\hline 1429B-4H-6W-147 & 30.40 & 48.80 & 22.90 & 1.3 & -21.19 & 0.15 & 8.06 \\
\hline 1429B-4H-7W-57 & 30.97 & 49.65 & 25.25 & 1.6 & -20.76 & 0.12 & 8.89 \\
\hline $1429 A-4 H-4 W-147$ & 31.37 & 50.25 & 12.21 & 1.99 & -20.87 & 0.17 & 6.47 \\
\hline $1429 A-4 H-5 W-57$ & 31.97 & 51.15 & 11.22 & 1.73 & -20.75 & 0.15 & 6.72 \\
\hline $1429 A-4 H-5 W-107$ & 32.47 & 51.90 & 11.36 & 1.39 & -21.66 & 0.16 & 6.53 \\
\hline $1429 A-4 H-5 W-147$ & 32.87 & 52.49 & 11.89 & 1.5 & -21.31 & 0.14 & 6.66 \\
\hline $1429 A-4 H-6 W-57$ & 33.47 & 53.39 & 12.85 & 1.35 & -21.31 & 0.12 & 6.52 \\
\hline 1429A-4H-6W-107 & 33.97 & 54.13 & 15.18 & 1.84 & -21.12 & 0.13 & 6.51 \\
\hline $1429 A-4 H-6 W-147$ & 34.37 & 54.73 & 14.30 & 1.92 & -20.56 & 0.12 & 6.14 \\
\hline 1429B-5H-3W-57 & 34.81 & 55.61 & 29.17 & 1.5 & -21.19 & 0.11 & 8.82 \\
\hline
\end{tabular}




\begin{tabular}{|c|c|c|c|c|c|c|c|}
\hline 1429B-5H-3W-107 & 35.31 & 56.78 & 35.77 & 2.2 & -21.19 & 0.13 & 7.43 \\
\hline 1429B-5H-3W-147 & 36.70 & 60.00 & 36.30 & 2.1 & -21.12 & 0.12 & 7.97 \\
\hline 1429B-5H-4W-147 & 37.14 & 61.03 & 37.43 & 1.8 & -21.32 & 0.11 & 9.19 \\
\hline 1429B-5H-5W-57 & 37.72 & 62.37 & 16.15 & 1.8 & -20.76 & 0.11 & 7.95 \\
\hline 1429B-5H-5W-107 & 38.20 & 63.49 & 29.28 & 1.8 & -20.70 & 0.14 & 7.06 \\
\hline 1429B-5H-5W-147 & 38.58 & 64.39 & 34.70 & 2.2 & -20.95 & 0.10 & 9.10 \\
\hline 1429B-5H-6W-47 & 39.04 & 65.46 & 34.46 & 2.2 & -20.73 & 0.13 & 8.31 \\
\hline 1429A-5H-4W-107 & 40.47 & 68.78 & 25.49 & 2.27 & -20.56 & 0.16 & 5.97 \\
\hline $1429 A-5 H-4 W-147$ & 40.87 & 69.71 & 23.06 & 2.12 & -20.81 & 0.15 & 5.45 \\
\hline $1429 A-5 H-5 W-57$ & 41.47 & 71.11 & 25.72 & 1.73 & -20.24 & 0.13 & 6.25 \\
\hline $1429 A-5 H-5 W-107$ & 41.97 & 72.28 & 27.58 & 2.14 & -20.51 & 0.14 & 5.82 \\
\hline 1429A-5H-5W-147 & 42.37 & 73.21 & 32.19 & 1.50 & -20.29 & 0.13 & 5.82 \\
\hline 1429B-6H-2W-107 & 42.73 & 74.04 & 39.77 & 2.2 & -20.69 & 0.13 & 6.89 \\
\hline 1429B-6H-3W-57 & 43.45 & 75.75 & 37.84 & 1.4 & -20.99 & 0.09 & 10.17 \\
\hline 1429A-5H-6W-107 & 43.47 & 75.81 & 22.74 & 1.84 & -20.39 & 0.15 & 6.75 \\
\hline 1429B-6H-3W-107 & 43.82 & 76.67 & 42.84 & 2.5 & -21.10 & 0.12 & 8.07 \\
\hline $1429 A-5 H-6 W-147$ & 43.87 & 76.79 & 19.78 & 2.55 & -20.42 & 0.14 & 6.68 \\
\hline 1429B-6H-3W-147 & 44.11 & 77.37 & 40.54 & 2.5 & -21.31 & 0.12 & 7.02 \\
\hline 1429B-6H-4W-107 & 44.90 & 79.31 & 41.59 & 2.0 & -20.88 & 0.13 & 4.83 \\
\hline 1429B-6H-4W-147 & 45.18 & 80.01 & 41.02 & 1.9 & -21.28 & 0.10 & 7.82 \\
\hline 1429A-7H-1W-57 & 52.17 & 91.00 & 29.97 & 1.45 & -17.73 & 0.14 & 5.58 \\
\hline 1429A-7H-1W-107 & 52.67 & 91.00 & 30.78 & 2.22 & -20.71 & 0.14 & 6.22 \\
\hline $1429 \mathrm{~A}-7 \mathrm{H}-1 \mathrm{~W}-147$ & 53.07 & 91.00 & 31.38 & 1.80 & -20.27 & 0.14 & 5.72 \\
\hline 1429A-7H-2W-57 & 53.67 & 92.25 & 26.79 & 2.06 & -20.69 & 0.14 & 6.16 \\
\hline 1429A-7H-2W-107 & 54.17 & 93.36 & 26.10 & 2.02 & -20.34 & 0.13 & 6.03 \\
\hline 1429A-7H-2W-147 & 54.57 & 94.26 & 26.85 & 1.87 & -20.47 & 0.13 & 6.34 \\
\hline 1429A-7H-3W-57 & 55.17 & 95.59 & 23.60 & 2.19 & -21.94 & 0.14 & 5.71 \\
\hline 1429A-7H-3W-107 & 55.67 & 96.71 & 25.26 & 2.4 & -20.84 & 0.16 & 6.20 \\
\hline
\end{tabular}




\begin{tabular}{|c|c|c|c|c|c|c|c|}
\hline 1429A-7H-3W-147 & 56.07 & 97.60 & 24.79 & 2.15 & -20.87 & 0.13 & 6.39 \\
\hline 1429A-7H-4W-57 & 56.67 & 98.94 & 26.46 & 2.27 & -20.42 & 0.16 & 5.55 \\
\hline 1429A-7H-4W-107 & 57.17 & 100.06 & 26.35 & 1.74 & -20.75 & 0.16 & 5.43 \\
\hline 1429A-7H-5W-57 & 58.17 & 102.29 & 25.99 & 2.21 & -20.95 & 0.15 & 5.36 \\
\hline 1429A-7H-5W-107 & 58.67 & 103.40 & 19.09 & 1.61 & -20.64 & 0.14 & 5.68 \\
\hline 1429A-7H-5W-147 & 59.07 & 104.29 & 29.03 & 2.11 & -21.28 & 0.14 & 5.64 \\
\hline 1429A-7H-6W-107 & 60.17 & 106.75 & 36.78 & 2.04 & -21.29 & 0.13 & 6.27 \\
\hline 1429A-7H-6W-147 & 60.57 & 107.64 & 28.93 & 1.99 & -21.45 & 0.13 & 5.95 \\
\hline 1429B-8H-3W-107 & 61.28 & 109.39 & 38.12 & 1.5 & -21.08 & 0.11 & 8.97 \\
\hline 1429B-8H-4W-57 & 62.21 & 113.25 & 11.96 & 0.4 & -21.14 & 0.13 & 6.55 \\
\hline 1429B-8H-4W-107 & 62.70 & 115.30 & 37.91 & 1.5 & -21.08 & 0.10 & 9.27 \\
\hline 1429B-8H-4W-147 & 63.06 & 116.80 & 26.38 & 1.27 & -22.30 & 0.11 & 8.70 \\
\hline 1429B-8H-5W-57 & 63.65 & 119.25 & 19.69 & 1.26 & -22.25 & 0.11 & 8.44 \\
\hline 1429B-8H-5W-107 & 64.13 & 121.22 & 33.19 & 1.30 & -22.07 & 0.12 & 8.58 \\
\hline 1429B-8H-5W-147 & 64.51 & 122.79 & 11.69 & 1.06 & -22.11 & 0.11 & 8.64 \\
\hline $1429 \mathrm{C}-10 \mathrm{H}-2 \mathrm{~W}-57$ & 65.07 & 125.13 & 14.72 & 1.52 & -20.71 & 0.14 & 7.23 \\
\hline 1429B-8H-6W-57 & 65.08 & 125.18 & 15.67 & 1.13 & -22.28 & 0.11 & 8.57 \\
\hline $1429 \mathrm{C}-10 \mathrm{H}-2 \mathrm{~W}-107$ & 65.57 & 127.21 & 13.29 & 1.48 & -21.19 & 0.13 & 7.28 \\
\hline $1429 \mathrm{C}-10 \mathrm{H}-2 \mathrm{~W}-147$ & 65.97 & 128.88 & 13.58 & 1.58 & -21.19 & 0.14 & 6.50 \\
\hline $1429 \mathrm{C}-10 \mathrm{H}-3 \mathrm{~W}-57$ & 66.57 & 130.65 & 11.08 & 1.64 & -21.35 & 0.14 & 8.27 \\
\hline $1429 \mathrm{C}-10 \mathrm{H}-3 \mathrm{~W}-107$ & 67.07 & 131.63 & 12.49 & 1.66 & -21.03 & 0.15 & 7.38 \\
\hline $1429 \mathrm{C}-10 \mathrm{H}-3 \mathrm{~W}-147$ & 67.47 & 132.41 & 13.27 & 1.61 & -20.96 & 0.14 & 7.31 \\
\hline $1429 \mathrm{C}-10 \mathrm{H}-4 \mathrm{~W}-57$ & 68.07 & 133.59 & 12.22 & 1.57 & -20.91 & 0.14 & 7.71 \\
\hline $1429 \mathrm{C}-10 \mathrm{H}-4 \mathrm{~W}-107$ & 68.57 & 134.57 & 15.70 & 1.57 & -21.22 & 0.13 & 7.32 \\
\hline $1429 \mathrm{C}-10 \mathrm{H}-4 \mathrm{~W}-147$ & 68.97 & 135.35 & 17.56 & 1.54 & -21.11 & 0.13 & 7.11 \\
\hline $1429 \mathrm{C}-10 \mathrm{H}-5 \mathrm{~W}-57$ & 69.57 & 136.53 & 15.82 & 1.31 & -21.20 & 0.12 & 8.60 \\
\hline $1429 \mathrm{C}-10 \mathrm{H}-5 \mathrm{~W}-107$ & 70.07 & 137.51 & 16.43 & 1.42 & -21.35 & 0.12 & 7.53 \\
\hline $1429 \mathrm{C}-10 \mathrm{H}-5 \mathrm{~W}-147$ & 70.47 & 138.29 & 13.28 & 1.32 & -20.71 & 0.13 & 7.36 \\
\hline
\end{tabular}




\begin{tabular}{|c|c|c|c|c|c|c|c|}
\hline $1429 \mathrm{C}-10 \mathrm{H}-6 \mathrm{~W}-57$ & 71.07 & 139.47 & 14.61 & 1.45 & -20.94 & 0.13 & 7.67 \\
\hline 1429C-10H-6W-107 & 71.57 & 140.36 & 15.21 & 0.26 & -22.82 & 0.12 & 7.78 \\
\hline $1429 \mathrm{C}-10 \mathrm{H}-6 \mathrm{~W}-147$ & 71.97 & 140.98 & 17.41 & 2.03 & -20.28 & 0.12 & 7.87 \\
\hline 1429A-9H-1W-148 & 72.08 & 141.15 & 16.38 & 1.31 & -20.44 & 0.12 & 7.16 \\
\hline $1429 A-9 H-2 W-107$ & 73.17 & 142.84 & 12.78 & 1.40 & -21.17 & 0.13 & 7.24 \\
\hline $1429 A-9 H-2 W-147$ & 73.57 & 143.46 & 13.13 & 1.37 & -20.91 & 0.14 & 6.97 \\
\hline 1429A-9H-3W-57 & 74.17 & 144.39 & 9.68 & 1.28 & -20.80 & 0.13 & 7.18 \\
\hline $1429 A-9 H-3 W-107$ & 74.67 & 145.17 & 12.15 & 1.42 & -20.78 & 0.13 & 7.49 \\
\hline $1429 A-9 H-4 W-147$ & 76.57 & 148.12 & 11.95 & 1.29 & -20.97 & 0.13 & 7.13 \\
\hline $1429 A-9 H-5 W-107$ & 77.67 & 149.83 & 12.02 & 1.24 & -21.08 & 0.13 & 7.49 \\
\hline 1429A-9H-6W-57 & 78.67 & 151.38 & 12.32 & 1.19 & -21.17 & 0.12 & 7.20 \\
\hline 1429A-9H-6W-107 & 79.17 & 152.16 & 14.06 & 1.14 & -21.14 & 0.12 & 7.09 \\
\hline 1429B-10H-4W-57 & 81.26 & 155.51 & 15.86 & 1.18 & -22.46 & 0.11 & 8.70 \\
\hline 1429B-10H-4W-107 & 81.74 & 156.44 & 12.89 & 1.05 & -22.34 & 0.11 & 8.07 \\
\hline 1429B-10H-5W-57 & 82.70 & 158.32 & 11.99 & 1.03 & -22.40 & 0.11 & 9.08 \\
\hline 1429B-10H-5W-107 & 83.17 & 159.24 & 12.17 & 1.32 & -20.92 & 0.11 & 9.16 \\
\hline 1429A-10H-3W-57 & 83.67 & 160.22 & 17.49 & 1.50 & -20.89 & 0.13 & 6.62 \\
\hline 1429B-10H-6W-57 & 84.12 & 161.11 & 10.35 & 1.35 & -21.38 & 0.12 & 6.38 \\
\hline $1429 \mathrm{~A}-10 \mathrm{H}-3 \mathrm{~W}-147$ & 84.57 & 161.98 & 22.19 & 1.90 & -20.46 & 0.14 & 6.95 \\
\hline 1429B-10H-6W-147 & 84.97 & 162.77 & 11.29 & 1.32 & -20.84 & 0.12 & 8.66 \\
\hline $1429 A-10 H-4 W-57$ & 85.17 & 163.15 & 20.07 & 1.87 & -20.61 & 0.14 & 7.01 \\
\hline 1429A-10H-4W-107 & 85.67 & 164.13 & 21.29 & 1.46 & -20.43 & 0.12 & 7.19 \\
\hline $1429 \mathrm{~A}-10 \mathrm{H}-4 \mathrm{~W}-147$ & 86.07 & 164.91 & 18.25 & 1.37 & -20.55 & 0.11 & 7.07 \\
\hline 1429A-10H-5W-57 & 86.67 & 166.08 & 21.34 & 1.98 & -20.51 & 0.14 & 6.75 \\
\hline 1429A-10H-5W-107 & 87.17 & 167.06 & 18.91 & 1.91 & -20.36 & 0.15 & 6.86 \\
\hline 1429A-10H-5W-147 & 87.57 & 167.83 & 16.92 & 1.43 & -20.7 & 0.12 & 7.02 \\
\hline 1429B-11H-2W-107 & 88.37 & 169.39 & 12.74 & 1.51 & -20.93 & 0.12 & 8.22 \\
\hline 1429B-11H-3W-57 & 89.35 & 171.29 & 10.08 & 1.56 & -20.97 & 0.12 & 7.71 \\
\hline
\end{tabular}




\begin{tabular}{|c|c|c|c|c|c|c|c|}
\hline 1429B-11H-3W-107 & 89.83 & 172.22 & 13.61 & 1.10 & -20.95 & 0.11 & 8.91 \\
\hline 1429B-11H-3W-147 & 90.22 & 172.97 & 14.59 & 1.88 & -20.86 & 0.13 & 8.11 \\
\hline 1429B-11H-4W-57 & 90.80 & 174.09 & 26.20 & 1.91 & -20.76 & 0.11 & 8.15 \\
\hline 1429B-11H-4W-107 & 91.29 & 174.94 & 27.90 & 1.97 & -21.16 & 0.10 & 8.52 \\
\hline 1429B-11H-4W-147 & 91.67 & 175.61 & 30.48 & 1.35 & -21.51 & 0.11 & 8.38 \\
\hline 1429B-11H-5W-57 & 92.25 & 176.62 & 31.30 & 1.41 & -21.45 & 0.11 & 8.85 \\
\hline 1429B-11H-5W-107 & 92.73 & 177.46 & 34.05 & 1.06 & -21.36 & 0.13 & 6.63 \\
\hline 1429B-11H-5W-147 & 93.09 & 178.10 & 24.68 & 1.60 & -21.55 & 0.12 & 6.83 \\
\hline $1429 C-13 H-2 W-57$ & 93.57 & 178.93 & 26.16 & 1.50 & -21.18 & 0.11 & 5.64 \\
\hline 1429B-11H-6W-57 & 93.67 & 179.10 & 27.87 & 1.60 & -21.31 & 0.13 & 6.68 \\
\hline 1429B-11H-6W-107 & 94.17 & 179.98 & 36.67 & 1.58 & -21.13 & 0.12 & 7.84 \\
\hline 1429B-11H-6W-147 & 94.55 & 180.65 & 41.37 & 1.83 & -21.09 & 0.13 & 5.70 \\
\hline $1429 \mathrm{C}-13 \mathrm{H}-2 \mathrm{~W}-107$ & 95.07 & 181.55 & 31.65 & 1.82 & -21.01 & 0.12 & 5.43 \\
\hline 1429C-13H-3W-57 & 95.07 & 181.55 & 26.32 & 1.25 & -20.99 & 0.11 & 6.83 \\
\hline $1429 \mathrm{C}-13 \mathrm{H}-2 \mathrm{~W}-147$ & 95.47 & 182.25 & 18.02 & 1.10 & -21.36 & 0.08 & 7.13 \\
\hline $1429 \mathrm{C}-13 \mathrm{H}-3 \mathrm{~W}-107$ & 95.57 & 182.43 & 13.88 & 1.37 & -22.06 & 0.09 & 9.26 \\
\hline $1429 \mathrm{C}-13 \mathrm{H}-3 \mathrm{~W}-147$ & 95.97 & 183.13 & 25.17 & 1.50 & -21.37 & 0.09 & 7.35 \\
\hline 1429C-13H-4W-57 & 96.57 & 184.18 & 20.58 & 1.73 & -21.07 & 0.12 & 6.45 \\
\hline $1429 \mathrm{C}-13 \mathrm{H}-4 \mathrm{~W}-107$ & 97.07 & 185.07 & 28.08 & 1.53 & -20.83 & 0.11 & 7.61 \\
\hline $1429 \mathrm{C}-13 \mathrm{H}-4 \mathrm{~W}-147$ & 97.47 & 186.07 & 28.32 & 1.72 & -21.22 & 0.10 & 6.00 \\
\hline 1429C-13H-5W-57 & 98.07 & 187.57 & 21.88 & 1.92 & -21.26 & 0.12 & 7.09 \\
\hline $1429 \mathrm{C}-13 \mathrm{H}-5 \mathrm{~W}-107$ & 98.57 & 188.81 & 23.07 & 1.71 & -20.51 & 0.11 & 6.11 \\
\hline $1429 C-13 H-5 W-147$ & 98.97 & 189.81 & 20.52 & 2.06 & -21.22 & 0.10 & 6.69 \\
\hline $1429 C-13 H-6 W-57$ & 99.57 & 191.31 & 2.46 & 1.65 & -20.77 & 0.03 & 13.40 \\
\hline $1429 \mathrm{~A}-12 \mathrm{H}-1 \mathrm{~W}-57$ & 99.67 & 191.55 & 4.11 & 0.30 & -22.64 & 0.03 & 7.00 \\
\hline $1429 \mathrm{C}-13 \mathrm{H}-6 \mathrm{~W}-107$ & 100.07 & 192.55 & 29.44 & 1.85 & -21.15 & 0.12 & 7.49 \\
\hline $1429 \mathrm{~A}-12 \mathrm{H}-1 \mathrm{~W}-107$ & 100.17 & 192.80 & 2.16 & 0.17 & -23.68 & 0.03 & 8.72 \\
\hline $1429 \mathrm{~A}-12 \mathrm{H}-2 \mathrm{~W}-57$ & 101.17 & 195.29 & 3.07 & 0.16 & -23.46 & 0.02 & 9.46 \\
\hline
\end{tabular}




\begin{tabular}{|c|c|c|c|c|c|c|c|}
\hline $1429 \mathrm{~A}-12 \mathrm{H}-2 \mathrm{~W}-107$ & 101.67 & 196.54 & 0.70 & 0.10 & -24.74 & 0.02 & 7.56 \\
\hline $1429 \mathrm{~A}-12 \mathrm{H}-2 \mathrm{~W}-147$ & 102.07 & 197.54 & 5.45 & 0.28 & -23.15 & 0.03 & 5.41 \\
\hline $1429 A-12 H-3 W-57$ & 102.67 & 199.03 & 23.44 & 1.74 & -21.51 & 0.12 & 6.85 \\
\hline $1429 \mathrm{~A}-12 \mathrm{H}-3 \mathrm{~W}-107$ & 103.17 & 200.28 & 25.74 & 1.92 & -20.95 & 0.13 & 7.18 \\
\hline $1429 A-12 H-4 W-57$ & 104.17 & 202.66 & 19.00 & 1.52 & -21.35 & 0.12 & 7.42 \\
\hline $1429 \mathrm{~A}-12 \mathrm{H}-4 \mathrm{~W}-107$ & 104.67 & 203.83 & 17.70 & 1.35 & -21.15 & 0.11 & 6.93 \\
\hline $1429 \mathrm{~A}-12 \mathrm{H}-4 \mathrm{~W}-147$ & 105.07 & 204.77 & 17.33 & 1.41 & -21.06 & 0.12 & 6.90 \\
\hline 1429A-12H-6W-57 & 107.17 & 209.69 & 16.64 & 1.60 & -21.16 & 0.13 & 6.65 \\
\hline 1429B-13H-4W-57 & 107.56 & 210.60 & 15.22 & 1.66 & -21.58 & 0.13 & 6.86 \\
\hline 1429B-13H-4W-107 & 108.04 & 211.72 & 10.66 & 2.16 & -21.77 & 0.15 & 6.13 \\
\hline 1429B-13H-5W-57 & 109.00 & 213.98 & 18.78 & 1.32 & -22.26 & 0.10 & 5.50 \\
\hline 1429B-13H-5W-107 & 109.48 & 215.10 & 19.60 & 1.34 & -22.15 & 0.11 & 7.83 \\
\hline 1429B-13H-5W-147 & 109.87 & 216.00 & 20.43 & 1.69 & -21.27 & 0.13 & 6.21 \\
\hline 1429B-13H-6W-57 & 110.44 & 217.33 & 19.04 & 1.75 & -21.34 & 0.12 & 5.18 \\
\hline 1429B-13H-6W-107 & 110.92 & 218.39 & 11.68 & 2.17 & -21.27 & 0.14 & 5.86 \\
\hline 1429B-13H-6W-147 & 111.31 & 219.23 & 2.37 & 2.14 & -21.27 & 0.14 & 6.36 \\
\hline 1429B-13H-7W-57 & 111.89 & 220.52 & 2.51 & 2.11 & -21.62 & 0.13 & 5.71 \\
\hline $1429 A-13 H-3 W-57$ & 112.17 & 221.13 & 22.51 & 1.32 & -21.49 & 0.12 & 7.32 \\
\hline 1429B-13H-7W-107 & 112.38 & 221.58 & 1.19 & 1.82 & -21.70 & 0.11 & 6.29 \\
\hline 1429A-13H-4W-57 & 113.67 & 224.42 & 3.70 & 0.33 & -23.10 & 0.04 & 5.82 \\
\hline $1429 \mathrm{~A}-13 \mathrm{H}-4 \mathrm{~W}-107$ & 117.17 & 232.10 & 3.48 & 0.21 & -23.24 & 0.03 & 6.12 \\
\hline 1429A-13H-5W-57 & 118.17 & 234.30 & 2.25 & 0.10 & -23.72 & 0.02 & 6.53 \\
\hline $1429 A-15 H-1 W-57$ & 118.67 & 235.40 & 7.69 & 0.07 & -23.81 & 0.02 & 8.05 \\
\hline $1429 \mathrm{~A}-15 \mathrm{H}-1 \mathrm{~W}-107$ & 119.17 & 236.50 & 13.96 & 1.27 & -21.34 & 0.13 & 7.47 \\
\hline $1429 A-15 H-2 W-57$ & 120.17 & 238.48 & 10.29 & 1.41 & -21.05 & 0.14 & 6.83 \\
\hline $1429 \mathrm{~A}-15 \mathrm{H}-2 \mathrm{~W}-147$ & 121.07 & 240.21 & 12.22 & 1.62 & -20.98 & 0.16 & 6.78 \\
\hline $1429 A-15 H-3 W-57$ & 121.67 & 241.37 & 11.32 & 1.68 & -21.07 & 0.16 & 6.91 \\
\hline $1429 \mathrm{~A}-15 \mathrm{H}-3 \mathrm{~W}-107$ & 122.17 & 242.00 & 12.88 & 1.33 & -21.28 & 0.13 & 6.58 \\
\hline
\end{tabular}




\begin{tabular}{|c|c|c|c|c|c|c|c|}
\hline $1429 \mathrm{~A}-15 \mathrm{H}-3 \mathrm{~W}-147$ & 122.57 & 242.00 & 11.32 & 1.35 & -21.43 & 0.14 & 7.01 \\
\hline 1429B-16H-2W-57 & 124.08 & 242.00 & 11.33 & 1.58 & -21.75 & 0.13 & 3.59 \\
\hline 1429B-16H-2W-107 & 124.58 & 242.00 & 10.96 & 1.26 & -20.96 & 0.13 & 7.72 \\
\hline 1429B-16H-3W-57 & 125.40 & 242.00 & 3.91 & 1.54 & -21.04 & 0.14 & 5.72 \\
\hline 1429B-16H-3W-107 & 125.90 & 242.00 & 12.28 & 1.71 & -21.37 & 0.15 & 7.49 \\
\hline 1429B-16H-4W-57 & 126.90 & 243.39 & 13.20 & 1.77 & -21.03 & 0.15 & 7.58 \\
\hline $1429 \mathrm{C}-18 \mathrm{H}-4 \mathrm{~W}-107$ & 130.27 & 252.48 & 16.51 & 1.28 & -21.18 & 0.11 & 7.26 \\
\hline $1429 \mathrm{C}-18 \mathrm{H}-4 \mathrm{~W}-147$ & 130.67 & 253.19 & 19.60 & 1.28 & -21.28 & 0.10 & 7.57 \\
\hline $1429 \mathrm{C}-18 \mathrm{H}-5 \mathrm{~W}-57$ & 131.27 & 254.25 & 6.34 & 0.81 & -21.80 & 0.08 & 6.13 \\
\hline $1429 \mathrm{C}-18 \mathrm{H}-5 \mathrm{~W}-107$ & 131.77 & 255.14 & 3.65 & 1.05 & -21.86 & 0.10 & 8.55 \\
\hline $1429 \mathrm{C}-18 \mathrm{H}-5 \mathrm{~W}-148$ & 132.18 & 255.87 & 15.70 & 1.41 & -21.48 & 0.12 & 7.30 \\
\hline 1429C-19H-3W-57 & 137.72 & 265.70 & 31.05 & 2.09 & -21.18 & 0.13 & 6.94 \\
\hline $1429 \mathrm{C}-19 \mathrm{H}-3 \mathrm{~W}-107$ & 138.22 & 266.59 & 31.66 & 1.67 & -21.48 & 0.11 & 7.63 \\
\hline $1429 \mathrm{C}-19 \mathrm{H}-3 \mathrm{~W}-147$ & 138.62 & 267.30 & 24.86 & 1.40 & -21.47 & 0.11 & 5.50 \\
\hline $1429 \mathrm{C}-19 \mathrm{H}-4 \mathrm{~W}-57$ & 139.22 & 268.36 & 28.38 & 1.30 & -21.13 & 0.09 & 7.58 \\
\hline $1429 \mathrm{C}-19 \mathrm{H}-4 \mathrm{~W}-107$ & 139.72 & 269.32 & 39.55 & 1.62 & -22.21 & 0.09 & 6.68 \\
\hline $1429 \mathrm{C}-19 \mathrm{H}-4 \mathrm{~W}-147$ & 140.12 & 270.24 & 27.51 & 1.26 & -21.37 & 0.09 & 5.66 \\
\hline $1429 \mathrm{C}-19 \mathrm{H}-5 \mathrm{~W}-57$ & 140.75 & 271.68 & 23.34 & 1.60 & -21.37 & 0.11 & 7.12 \\
\hline $1429 \mathrm{C}-19 \mathrm{H}-5 \mathrm{~W}-107$ & 141.25 & 272.82 & 28.53 & 1.36 & -20.97 & 0.09 & 7.35 \\
\hline $1429 \mathrm{C}-19 \mathrm{H}-5 \mathrm{~W}-147$ & 141.65 & 273.74 & 23.67 & 1.34 & -21.54 & 0.10 & 5.46 \\
\hline $1429 \mathrm{C}-19 \mathrm{H}-6 \mathrm{~W}-57$ & 142.25 & 275.11 & 23.45 & 1.62 & -21.14 & 0.11 & 7.16 \\
\hline $1429 \mathrm{C}-20 \mathrm{H}-3 \mathrm{~W}-57$ & 146.36 & 285.02 & 26.44 & 1.79 & -21.20 & 0.12 & 6.49 \\
\hline $1429 \mathrm{C}-20 \mathrm{H}-3 \mathrm{~W}-107$ & 146.86 & 286.55 & 34.92 & 1.19 & -22.19 & 0.08 & 7.86 \\
\hline $1429 \mathrm{C}-20 \mathrm{H}-3 \mathrm{~W}-147$ & 147.26 & 287.78 & 36.30 & 1.55 & -21.67 & 0.09 & 7.40 \\
\hline $1429 \mathrm{~A}-18 \mathrm{H}-2 \mathrm{~W}-107$ & 149.17 & 293.63 & 2.76 & 0.13 & -24.17 & & \\
\hline $1429 \mathrm{~A}-18 \mathrm{H}-3 \mathrm{~W}-107$ & 150.67 & 298.22 & 41.20 & 0.90 & -21.80 & 0.06 & 3.78 \\
\hline $1429 \mathrm{~A}-20 \mathrm{H}-2 \mathrm{~W}-57$ & 159.67 & 325.78 & 10.13 & 0.69 & -23.55 & 0.06 & 6.44 \\
\hline $1429 \mathrm{~A}-20 \mathrm{H}-2 \mathrm{~W}-147$ & 160.57 & 328.54 & 15.70 & 0.94 & -21.10 & 0.11 & 4.04 \\
\hline
\end{tabular}




\begin{tabular}{llllllll}
\hline $1429 \mathrm{~A}-20 \mathrm{H}-3 \mathrm{~W}-57$ & 161.17 & 330.18 & 19.81 & 0.51 & -21.45 & 0.10 & 7.64 \\
$1429 \mathrm{~A}-20 \mathrm{H}-4 \mathrm{~W}-57$ & 162.67 & 334.13 & 18.85 & 0.93 & -21.80 & 0.09 & 7.59 \\
$1429 \mathrm{~A}-20 \mathrm{H}-4 \mathrm{~W}-107$ & 163.17 & 335.45 & 17.47 & 0.93 & -21.16 & 0.10 & 4.95 \\
$1429 \mathrm{~A}-21 \mathrm{H}-2 \mathrm{~W}-57$ & 167.67 & 347.29 & 39.64 & 2.20 & -21.12 & 0.12 & 4.77 \\
$1429 \mathrm{~A}-21 \mathrm{H}-2 \mathrm{~W}-107$ & 168.17 & 348.61 & 33.33 & 1.56 & -21.21 & 0.10 & 4.18 \\
$1429 \mathrm{~A}-21 \mathrm{H}-2 \mathrm{~W}-147$ & 168.57 & 349.66 & 4.17 & 0.31 & -23.38 & 0.04 & 8.10 \\
$1429 \mathrm{~A}-21 \mathrm{H}-3 \mathrm{~W}-57$ & 169.17 & 351.24 & 41.17 & 2.00 & -21.00 & 0.10 & 3.94 \\
\hline
\end{tabular}




\section{VITA}

\section{HEATHER D. BLACK}

Born, Huntington, West Virginia

2008-2011

B.S., Environmental Science

University of Alabama

Tuscaloosa, Alabama

2012-2014

M.S., Geology

University of Alabama

Tuscaloosa, Alabama

2014-2019

Ph.D., Earth Systems Science

Florida International University

Miami, Florida

\section{PUBLICATIONS AND PRESENTATIONS}

Black, H.D., Anderson, W.T., and Alvarez-Zarikian, C. (December 2016). The MidPleistocene Transition and the resulting paleoproductivity cycles in the Japan Sea. American Geophysical Union Fall Meeting, San Francisco, California.

Black, H.D., Andrus, C.F.T., Rick, T.C., Lambert, W.J., and Gillikin, D.P. (2017). $\delta^{15} \mathrm{~N}$ values in Crassostrea virginica shells provide early direct evidence for nitrogen loading to Chesapeake Bay. Scientific Reports (7).

Black, H.D., Anderson, W.T., and Expedition 346 Scientists. (December 2017). Organic matter contents and paleoproductivity variation within Late Pleistocene Japan Sea/East Sea sediments: Results from IODP Expedition 346. American Geophysical Union Fall Meeting, New Orleans, Louisiana.

Black, H.D. (February 2017). Upwelling and the resulting paleoproductivity variations within the Japan Sea during the Late Pleistocene. FIU Earth and Environment Graduate Research Symposium. $3^{\text {rd }}$ place presentation.

Black, H.D., Anderson, W.T., and Alvarez-Zarikian, C. (2018). Organic matter, carbonate, and stable isotope stratigraphy from IODP Expedition 346 Sites U1426, U1427, and U1429. IODP Proceedings (346).

Gallagher, S.J., Sagawa, T., Henderson, A., Saavedra-Pellitero, M., De Vleeschouwer, D., Black, H.D., Itaki, T., Toucanne, S., Bassetti, M., Clemens, S., Anderson, W.T., and Tada, R. (2018). Paleoceanography and monsoonal history of the Japan Sea over the last 460,000 years. Paleoceanography and Paleoclimatology (33) 683-702. 
Black, H.D. and Anderson, W.T. (December 2018). The Mid-Pleistocene Transition and the resulting paleoproductivity cycles within the Japan Sea. American Geophysical Union Fall Meeting, Washington, D.C. 